UNIVERSIDADE DE SÃO PAULO

FACULDADE DE FILOSOFIA, LETRAS E CIÊNCIAS HUMANAS

DEPARTAMENTO DE SOCIOLOGIA

PROGRAMA DE PÓS-GRADUAÇÃO EM SOCIOLOGIA

MARIANA TOLEDO FERREIRA

Centro(s) e periferia(s) na produção do conhecimento em genética humana e médica: um olhar a partir do Brasil

VERSÃO CORRIGIDA

São Paulo

2018 


\title{
Centro(s) e periferia(s) na produção do conhecimento em genética humana e médica: um olhar a partir do Brasil
}

\author{
VERSÃO CORRIGIDA
}

Tese de doutorado apesentada ao programa de Pós-Graduação em Sociologia da Faculdade de Filosofia, Letras e Ciências Humanas da Universidade de São Paulo para obtenção do título de doutor em Sociologia sob a orientação da Profa. Dra. Sylvia Gemignani Garcia.

São Paulo

2018 
Autorizo a reprodução e divulgação total ou parcial deste trabalho, por qualquer meio convencional ou eletrônico, para fins de estudo e pesquisa, desde que citada a fonte.

Catalogação na Publicação

Serviço de Biblioteca e Documentação

Faculdade de Filosofia, Letras e Ciências Humanas da Universidade de São Paulo

F383C

Ferreira, Mariana Toledo

Centro(s) e periferia(s) na produção do

conhecimento em genética humana e médica: um olhar a

partir do Brasil / Mariana Toledo Ferreira ;

orientador Sylvia Gemignani Garcia. - São Paulo,

2018 .

$280 \mathrm{f}$.

Tese (Doutorado)- Faculdade de Filosofia, Letras e Ciências Humanas da Universidade de São Paulo. Departamento de Sociologia. Área de concentração: Sociologia.

1. divisão internacional do trabalho científico. 2. relações centro-periferia. 3. colaborações internacionais. 4. ciência brasileira. I. Garcia, Sylvia Gemignani, orient. II. Título. 
Para o Stefan, presença constante neste e em outros tantos caminhos 


\section{AGRADECIMENTOS}

Este trabalho seria completamente inviável sem a significativa contribuição das pesquisadoras e pesquisadores entrevistados, que dedicaram parte de seu precioso tempo a dividir comigo suas experiências. A eles expresso aqui toda minha gratidão e admiração.

À Sylvia Garcia, muito mais do que minha orientadora, meu ideal de socióloga, a quem eu devo grande parte da minha formação. Pela leitura sempre atenta e pelos comentários inseparavelmente críticos e instigantes, eu agradeço enormemente.

Agradeço também a Alvaro Comin e Maria Carlotto, pelas contribuições preciosas dadas no momento de minha qualificação, bem como às críticas e sugestões de continuidade dadas em minha defesa.

Agradeço enormemente a Fabricio Neves e Edison Bicudo, ambos dedicados a compreender as dinâmicas e constrições da ciência brasileira e que, de perspectivas diferentes, tanto enriqueceram minha defesa.

Aos integrantes do Grupo de Pesquisa em Sociologia da Educação, Cultura e Conhecimento. Em particular, agradeço a Ana Paula Hey, desde o início apoiadora do meu projeto.

Agradeço ao CNPq pelo suporte financeiro, sem o qual esta pesquisa não se realizaria.

Agradeço ao Instituo Federal de Goiás pelo afastamento concedido, que permitiu a realização do trabalho de campo necessário a esta pesquisa.

Aos meus amigos Rita, Diogo, Ciola, Legume, Victor e Preis, que nunca desapareceram da minha vida, embora esta tese tenha muitas vezes me afastado da deles. Agradeço pelo amor e companhia inestimável que já vem de longa data.

À Monique, Erica e Thais, minhas pessoas favoritas em todo o mundo. 
À Monise e Lucas, amigos e colegas de doutorado, que compartilharam comigo, mesmo que à distância, as agruras e pequenos prazeres de escrever uma tese.

Aos amigos que fiz em Brasília, Vanessa, Camila, Fabrício e Tiago, que caminham comigo nessa nova etapa da vida.

Enfim, a todos os amigos, citados ou não, que merecem muito mais do que essas linhas de agradecimento têm a oferecer.

Agradeço também aos meus tios, Cri e Lelo que acompanharam com interesse todos os meus passos acadêmicos.

Ao meu pai pelo apoio e amor incondicional. À Helena e à Tchan, companhia de muitas refeições e conversas de domingo, que foram ficando mais raras, infelizmente, no curso desses anos.

À minha mãe, que sempre acreditou em mim, nas minhas capacidades e sonhos e é quem me lembra que é preciso trabalhar, mas também comer bem, se movimentar, descansar, e, sobretudo, ser feliz.

Ao Stefan, a quem eu poderia agradecer por tantas coisas, mas que basta assinalar que vem seguindo junto comigo nessa dupla empreitada: fazer o doutorado, e, principalmente, ser feliz. 


\section{RESUMO}

A tese aborda diferentes dimensões da relação entre centros e periferias na produção, circulação e legitimação do conhecimento, a partir de um estudo de caso que se debruça sobre a área da genética humana e médica no Brasil. Busca-se discutir as razões, estratégias, contingências e constrições das colaborações internacionais realizadas pelas(os) pesquisadoras(es) brasileiras(os) em um contexto disciplinar percebido como estruturalmente desigual. Trata-se de explorar as potencialidades do estudo de caso para a identificação em termos mais específicos de fatores e processos que têm sido descritos de modo generalizante nos discursos contemporâneos sobre a internacionalização da ciência e a transformação dos modos de produção de conhecimento científico. Para tanto, foi feito um trabalho de campo que compreendeu a seleção de uma amostra de pesquisadoras(es) da genética humana e médica no Brasil, que levou à identificação dos programas de pós-graduação "de excelência" na área, localizados em quatro universidades públicas: Universidade de São Paulo - campus Ribeirão Preto; Universidade Estadual de Campinas; Universidade Federal do Pará; e Universidade Federal do Rio Grande do Sul. Essa seleção baseou-se na Avaliação Trienal da Capes 2010-2012 (que eram os dados mais recentes disponíveis quando do desenho da pesquisa). Foram então realizadas 46 entrevistas semiestruturadas com pesquisadoras(es) pertencentes às instituições em que esses Programas estão sediados, a grande maioria delas realizada in loco, para cuja análise foi utilizado o programa Atlas Ti. A exploração desse material, devidamente localizado no contexto histórico do desenvolvimento da área no país, permitiu analisar as representações das(os) pesquisadoras(es) em termos de estratégias negociadas e renegociadas no cotidiano das colaborações nacionais e internacionais e a constituição das agendas de pesquisa, simultaneamente em consonância e em tensão com os padrões e parâmetros do que se convencionou chamar de "ciência internacional". Os dados balizam a discussão sobre as possibilidades de reconhecimento da pesquisa em genética humana e médica realizada por brasileiras(os), que explora as tensões entre o local e o internacional, considerando os aspectos que marcam as formas contemporâneas de competição no interior de atividade científica em um campo disciplinar específico. A análise revela a pluralidade das relações entre centros e periferias, em dinâmicas sociais que transformam e recriam desigualdades nacionais, regionais e globais no campo contemporâneo da produção de conhecimento em genética humana e médica.

Palavras-chave: divisão internacional do trabalho científico; relações centro-periferia; colaborações internacionais; genética humana e médica; ciência brasileira. 


\begin{abstract}
This doctoral dissertation deals with different dimensions of the relation between centres and peripheries in the production, circulation and legitimation of knowledge, departing from a case study looking at human and medical Genetics in Brazil. Its aims are to discuss the reasons, strategies, contingencies and constrictions of international collaborations taken through by Brazilian researchers in a disciplinary context perceived as structurally unequal. Thus it is about exploring the potentialities of this case study to identify under more specific terms the factors and processes that have been hitherto described in a generalizing manner throughout contemporary discourses on internationalization of science and the transformation of the modes of production of scientific knowledge. To achieve this, a fieldwork has been taken through, comprehending the selection of a sample of researchers in the field of human and medical Genetics in Brazil, therefore leading to the identification of graduate programmes of "excellence", located in four public research universities: Universidade de São Paulo campus Ribeirão Preto; Universidade Estadual de Campinas; Universidade Federal do Pará, and Universidade Federal do Rio Grande do Sul. This selection based itself upon the 20102012 Triennial Evaluation Process of Capes (which were the most recent data available at the moment when the research happened to be designed). After this first preparatory step, 46 semi-structured interviews were held with researchers belonging to the institutions hosting these programmes, the most part of them in loco, after which the software Atlas Ti was used to analyse them. Exploring this material, duly situated in the historical context of the areas' development in Brazil, allowed to analyse the representations of these researchers in terms of the strategies employed to negotiate and renegotiate in everyday national as well as international collaborations, alongside the constitution of research agendas, all of them simultaneously in consonance and tension regarding patterns and parameters of what has been agreed upon to receive the name of "international science". This data appears as a yardstick to evaluate the discussion concerning the possibilities of recognizing research in human and medical Genetics performed by Brazilian researchers, examining tensions between the local and the international, taking into consideration the aspects that characterize contemporary forms of competition among scientific activity in a specific disciplinary field. The investigation and concurrent analysis reveal the plurality of relations between centres and peripheries, paying special attention to social dynamics that produce and recreate national, regional and global inequalities in the contemporary field of knowledge production in human and medical genetics.
\end{abstract}

Keywords: international division of scientific labour; center-periphery relations; international collaborations; human and medical genetics; Brazilian science. 


\section{LISTA DE TABELAS}

Tabela 1: Programas de Pós-Graduação em Genética, avaliados com nota 6 ou 7 (triênio 2010-2012)

Tabela 2: Panorama dos entrevistados por instituição

Tabela 3: Bolsistas de Produtividade CNPq divididos por sexo e nível (2015)

Tabela 4: Distribuição geográfica de pesquisadores em genética humana e médica (2015) e do total de docentes brasileiros (2013)

Tabela 5: Distribuição geográfica dos grupos de pesquisa em genética humana e médica cadastrados no $\mathrm{CNPq}-2016$

Tabela 6: Distribuição dos pesquisadores na região Sudeste (2015)

Tabela 7: Instituições com mais pesquisadores em genética humana (2015)

Tabela 8: Distribuição de bolsista de produtividade CNPq por região geográfica (2015)

Tabela 9: Bolsista PQ por instituição (cinco bolsas ou mais) - 2015

Tabela 10: Tipo de instituição em que se localizam os pesquisadores (2015)

Tabela 11: Inserção departamental (2015)

Tabela 12: Cursos de Graduação frequentados (2015)

Tabela 13: Programas de Pós-Graduação frequentados (2015)

Tabela 14: Curso de Graduação e Pós-Graduação frequentados (2015)

Tabela 15: Inserção profissional e titulação (2015)

Tabela 16: Inserção profissional e titulação - por departamento (2015)

Tabela 17: Década da inserção profissional e titulação

Tabela 18: Doutorado ou doutorado-sanduíche em instituições estrangeiras (2015)

Tabela 19: Década de início do doutorado

Tabela 20: País em que foi realizado o doutorado integral ou sanduíche (2015)

Tabela 21: Pós-doutorado no exterior - por região geográfica (2015)

Tabela 22: Proporção de pós-doutorados dentro e fora do país (2015) 
Tabela 23: Países em que foram realizados os pós-doutorados (2015)

Tabela 24: Instituições nacionais de realização do pós-doutorado (2015)

Tabela 25: Inserção profissional durante o pós-doutorado (2015)

Tabela 26: Padrões de trajetória dos pesquisadores em genética humana (2016)

Tabela 27: Trajetórias divididas por década de término do doutorado (2016)

Tabela 28: Padrões de trajetória divididos por região geográfica (2016)

Tabela 29: Padrão de trajetória geográfica dos pesquisadores em genética humana e médica (2016)

Tabela 30: Padrão de trajetória geográfica por região (2016)

Tabela 31: Avaliação Qualis Capes do periódico Plos One (quadriênio 2013-2016)

Tabela 32: Valores para a publicação na Public Library of Science (2018)

Tabela 33: Distribuição de artigos em colaboração, nos periódicos da PLOS (2016) 


\section{LISTA DE SIGLAS}

BNDES - Banco Nacional de Desenvolvimento Econômico e Social

CAPES - Coordenação de Aperfeiçoamento de Pessoal de Nível Superior

$\mathrm{CNPq}$ - Conselho Nacional de Desenvolvimento Científico e Tecnológico

Conep - Comissão Nacional de Ética em Pesquisa

CPDOC - Centro de Pesquisa e Documentação de História Contemporânea do Brasil

DAAD - Deutscher Akademischer Austauschdienst (Serviço Alemão de Intercâmbio Acadêmico)

DFG - Deutsche Forschungsgemeinschaft

DNA - Ácido desoxirribonucleico

ESALQ - Escola Superior de Agricultura "Luiz de Queiroz"

EUA - Estados Unidos da América

FAPESP - Fundação de Amparo à Pesquisa do Estado de São Paulo

FINEP - Financiadora de Estudos e Projetos

FFCL - Faculdade de Filosofia Ciências e Letras

FFLCH - Faculdade de Filosofia, Letras e Ciências Humanas

FGV - Fundação Getúlio Vargas

FMUSP - Faculdade de Medicina da Universidade de São Paulo

FUSP - Fundação de Apoio à Universidade de São Paulo

HCPA - Hospital de Clínicas de Porto Alegre

IAC - Instituto Agronômico de Campinas

IB - Instituto de Biociências

ICB - Instituto de Ciências Biomédicas

IES - Instituições de Ensino Superior

INCT - Instituto Nacional de Ciência e Tecnologia

ISI - Institute for Scientific Information

MCT - Ministério da Ciência e Tecnologia

MEC - Ministério da Educação

OEA - Organização dos Estados Americanos

OMS - Organização Mundial da Saúde

ONSA - Organization for Nucleotide Sequencing and Analysis

PGF - Projeto Genoma Fapesp

PGH - Projeto Genoma Humano

PNPG - Plano Nacional de Pós-Graduação

RNA - Ácido ribonucleico

SBG - Sociedade Brasileira de Genética 
SBPC - Sociedade Brasileira para o Progresso da Ciência

SUS - Sistema Único de Saúde

UFAL - Universidade Federal de Alagoas

UFBA - Universidade Federal da Bahia

UFCSPA - Universidade Federal de Ciências da Saúde de Porto Alegre UFG - Universidade Federal de Goiás

UFMG - Universidade Federal de Minas Gerais

UFMT - Universidade Federal de Mato Grosso

UFPA - Universidade Federal do Pará

UFPE - Universidade Federal de Pernambuco

UFPR - Universidade Federal do Paraná

UFRGS - Universidade Federal do Rio Grande do Sul

UFRJ - Universidade Federal do Rio de Janeiro

UFSC - Universidade Federal de Santa Catarina

UnB - Universidade de Brasília

UNESP - Universidade Estadual Paulista Júlio de Mesquita Filho

UNICAMP - Universidade Estadual de Campinas

UNIFESP - Universidade Federal de São Paulo

USP - Universidade de São Paulo 


\section{Sumário}

Agradecimentos.

Resumo

Abstract

Lista de tabelas

Lista de siglas.

Introdução

Capítulo 1

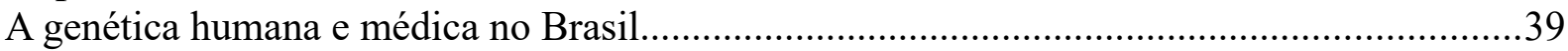

1.1 A institucionalização da pesquisa em genética no Brasil.................................................40

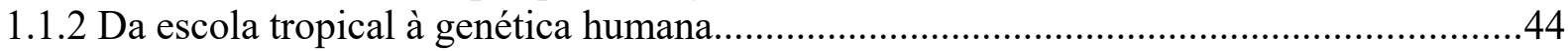

1.1.3 O papel da Fundação Rockefeller na institucionalização da pesquisa em genética e os contornos de uma divisão internacional do trabalho científico................................................46

$1.2 \mathrm{O}$ campo brasileiro da genética humana e médica no Brasil..........................................54

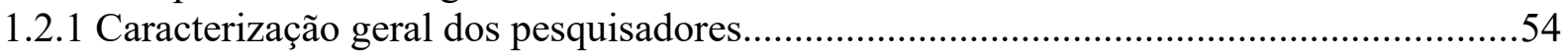

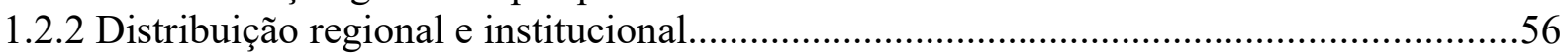

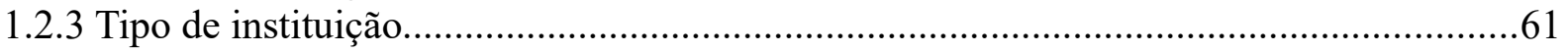

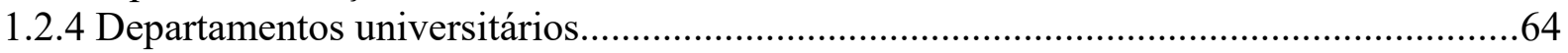

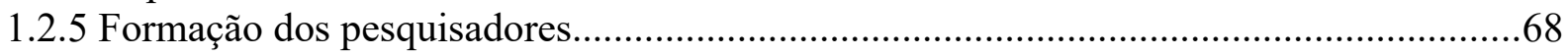

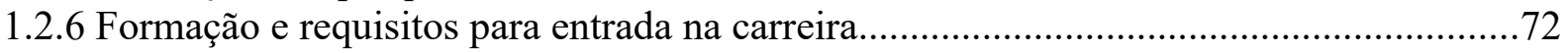

1.2.7 Formação dos pesquisadores: relação com o internacional.............................................74

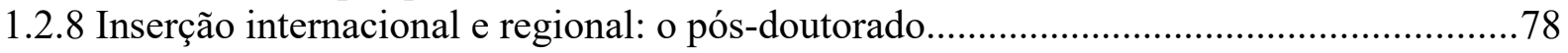

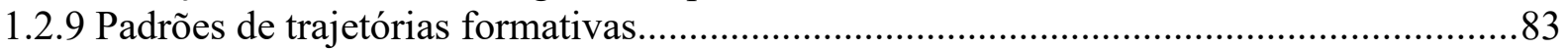

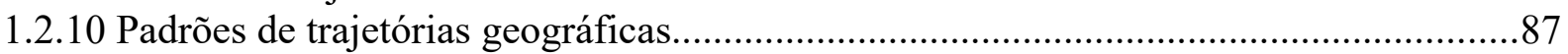

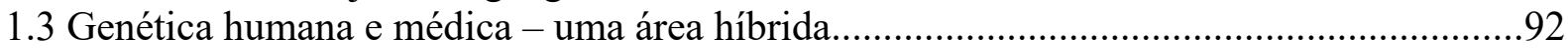

Interlúdio.

Divisão internacional do trabalho científico na genética humana e médica.

\section{Capítulo 2}

Explorando colaborações internacionais: rumo à identificação de dimensões da relação entre centros e periferias

2.1 Razões para visitar centros de pesquisa no exterior/realizar colaborações internacionais

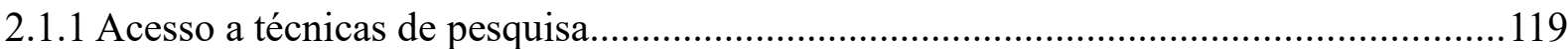

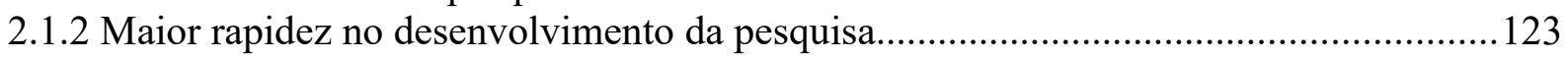

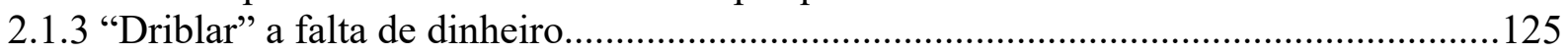

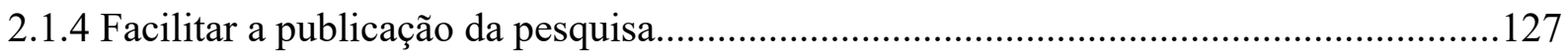

2.1.5 Participação em pesquisa de "grande amplitude".......................................................130

2.2 Periferia pensada em termos de "falta": contextualizando o cenário das colaborações

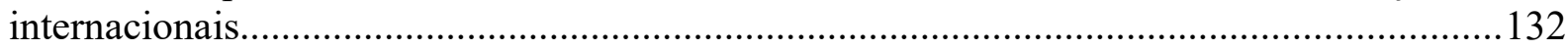

2.3 Dimensões principais da relação entre centros e periferias.............................................153 


\section{Capítulo 3}

Elementos e constrições da colaboração em pesquisa: aportes envolvendo a articulação e legitimação de uma agenda de pesquisa periférica.

3.1 Por que é interessante para pesquisadores estrangeiros colaborar com o Brasil?.............169

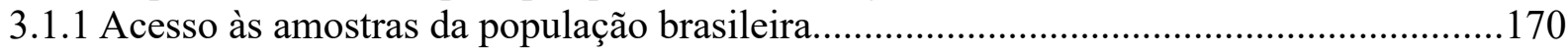

3.1.2 Pesquisadores brasileiros como "mão de obra barata".............................................178

3.1.3 Diversificação de temas de pesquisa, ampliação de publicações e pressão por "internacionalização".

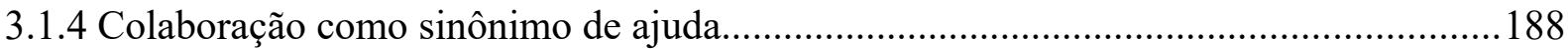

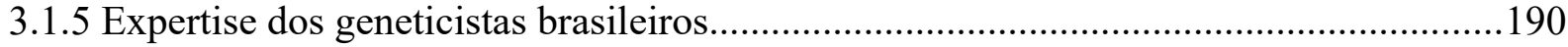

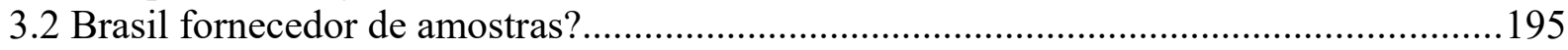

3.3 Construção de uma agenda de pesquisa periférica.........................................................207

3.4 Justificando uma agenda de pesquisa: "o que funciona em outras populações não

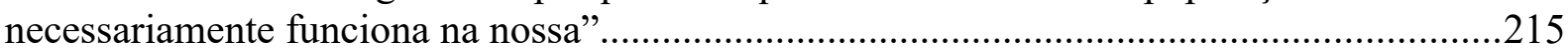

3.5 Reconhecimento de uma agenda de pesquisa: tensões entre a inserção local e o

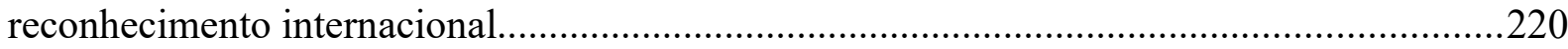

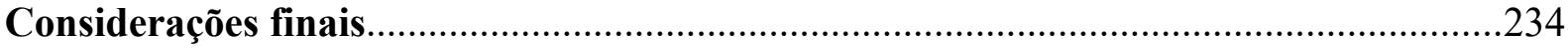

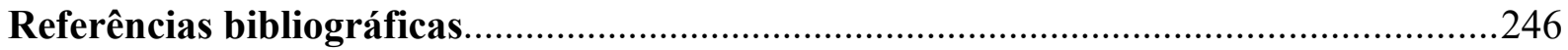

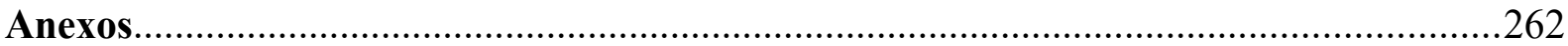

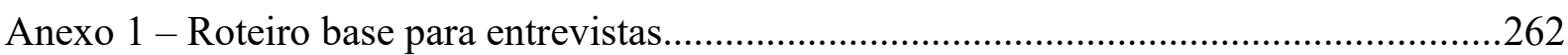

Anexo 2 - Instituições de ensino e pesquisa e número de pesquisadores da amostra............265

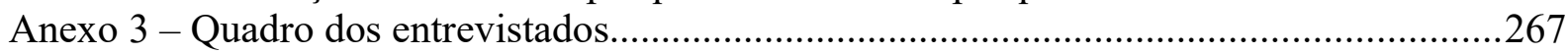




\section{INTRODUÇÃO}

O objetivo inicial desta pesquisa era, em poucas palavras, examinar a existência de uma divisão internacional do trabalho científico no campo da genética humana e médica, tomando por base observação e entrevistas em laboratórios e programas de pós-graduação brasileiros, e mobilizando a relação entre centros e periferias como um recurso analítico. Essa questão norteadora originou-se de três inquietações principais.

Uma inquietação empírica, formada em minha pesquisa de mestrado (Ferreira, 2013), cujo objetivo foi investigar a organização social do conhecimento e a produção social dos produtores de conhecimento em uma área específica - a genética humana e médica -, em termos de configurações institucionais, padrões de formação, padrões de carreira, organização e divisão do trabalho e práticas concretas de pesquisa, tomando por base o estudo de caso de um conjunto de laboratórios da Universidade de São Paulo, de modo a observar suas pesquisas, seus pesquisadores, e suas estratégias de institucionalização e legitimação. A pesquisa envolveu olhar para o processo de institucionalização da genética no Brasil e o papel significativo desempenhado pela Fundação Rockefeller nesse processo. Identificou-se, tanto no início da pesquisa de genética de populações com drosófilas, quanto na genética humana e médica, a busca de trabalhos que traziam certa facilidade de se inserir no espaço científico internacional. No primeiro caso, a utilização de espécies tropicais de drosófilas, não existentes em climas temperados, permitia a produção de dados não disponíveis nos centros de pesquisa de destaque na época. Na genética humana, tinha-se o estudo das populações isoladas, dos povos indígenas brasileiros e latinos, e da dinâmica da miscigenação. Nas duas linhas de pesquisa mostrou-se possível produzir dados originais, a partir de populações locais. Foi possível aos pesquisadores pioneiros se inserir em pesquisas mais amplas e comparativas, a partir dos achados de pesquisa locais, publicar em revistas de alto impacto, construir carreiras bem-sucedidas, sem ter que rivalizar com os centros de pesquisa internacionais mais bem organizados e financiados. Partindo dessa constatação empírica - discutida em mais detalhes no primeiro capítulo desta tese -, de uma divisão do trabalho científico que marcou o processo de institucionalização da pesquisa em genética, delimitei a questão principal do projeto de pesquisa de doutorado: investigar os processos contemporâneos de divisão internacional do trabalho científico.

Ao me debruçar sobre a literatura científica disponível acerca dos processos de divisão do trabalho científico, emergiu a segunda inquietação. Tal literatura está voltada a refletir 
acerca de possíveis transformações da atividade científica em um conjunto mais ou menos circunscrito de temas: a internacionalização da ciência, a constituição de redes internacionais de colaboração científica, os efeitos da globalização na atividade científica, a divisão internacional de tarefas, a discussão sobre a hierarquia internacional e a margem de manobra dos países não desenvolvidos. $\mathrm{E}$ isso tem sido feito crescentemente a partir do constructo centro e periferia, da oposição entre Norte e Sul ou da contraposição de países hegemônicos e não hegemônicos. Subjacente a esses temas, principalmente quando se reflete a partir dessas oposições, está a discussão entre a excelência e a pertinência da pesquisa científica na periferia. Esses estudos, no entanto, tendem a focar a produção do conhecimento em diferentes disciplinas das ciências sociais e humanidades, como a sociologia, a ciência política, ou a economia, e pouco se diz sobre as ciências ditas duras e seus mecanismos de produção e legitimação de conhecimento.

Mais importante é o fato de que parte significativa dessa discussão tem caráter conceitual ou programático. A partir de estudos baseados em indicadores quantitativos, muitos trabalhos mostraram a existência de uma desigualdade na produção de conhecimento: a maior parte das publicações indexadas são da América do Norte e União Europeia ${ }^{1}$, a maioria dos periódicos conceituados também são de lá, bem como a quase totalidade das universidades e institutos de pesquisa que ocupam as primeiras posições em rankings internacionais ${ }^{2}$. As desigualdades dessa estrutura e as distorções produzidas foram extensamente discutidas e criticadas, estando algumas dessas críticas baseadas em imagens de oposição: ciência indígena e colonial, Norte e Sul, Ocidental e Oriental. Boaventura de Sousa Santos (2010), por exemplo, enuncia uma linha abissal que a modernidade traça entre sociedades metropolitanas e territórios coloniais, entre um sistema de conhecimento imperialista e as epistemologias dos excluídos. Paulin Hountondji (2006) discute como a metrópole global acumula dados (em bibliotecas, museus, periódicos, bancos de dados) e, mais importante, é o local da produção de métodos e teorias, enquanto as regiões periféricas, ao contrário, são uma

1 Em 2008, por exemplo, a América do Norte e a União Europeia, juntas, produziram 67,6\% das publicações científicas mundiais registradas na Web of Science (Unesco, 2010, p. 10).

2 Ainda que possam ser questionados sob vários pontos de vista, dois dos principais rankings internacionais de 2017 ilustram bastante bem essa afirmação: no Times Higher Education Ranking, apenas três instituições - a National University of Singapore, a Tsinghua University e a The University of Tokyo - de fora do eixo América do Norte (de língua inglesa ou francesa) e Europa aparecem entre as cem primeiras posições, enquanto no ARWU World University Rankings da universidade de Shangai, tão somente duas instituições a Kyoto University e a Tsinghua University - alcançaram esse patamar. Nenhuma delas está entre as 20 mais conceituadas.

Cf. $<$ http://www.shanghairanking.com/ARWU2017.html $>$ e $<$ https://www.timeshighereducation.com/worlduniversity-rankings/2018/world-ranking\#!/page/0/length/25/sort by/rank/sort order/asc/cols/stats $>$. Acesso em $1^{\circ}$ de maio de 2018. 
fonte massiva de dados, coletados por viajantes da metrópole ou por trabalhadores locais, que atuam como informantes.

Mas há poucos estudos empíricos, na sociologia, olhando para as questões levantadas pelo pensamento pós-colonial e decolonial. Nesse sentido, o objetivo da tese passou a ser "ver na prática", em uma área específica de produção de conhecimento, como se desenvolveriam os processos de divisão do trabalho. Para além da denúncia ou da constatação geral de que há uma desigualdade no que tange à produção global de conhecimentos, o objetivo tornou-se tentar operacionalizar indicadores de divisão do trabalho e, mais do que isso, delinear os processos, escolhas estratégicas, situações, relacionamentos, detalhes concretos por meio dos quais essa divisão é produzida e reproduzida por aqueles que participam ativamente do processo de produção do conhecimento.

A terceira inquietação está mais ligada a questões de política científica e à literatura que trata das transformações contemporâneas na produção e circulação do conhecimento. As principais teorias sobre as transformações da ciência contemporânea que conseguem universalizar-se são elaboradas nos países centrais e, geralmente, a partir dos centros de pesquisa mais avançados. A título de exemplo, tem-se diagnósticos como o da emergência de uma cultura pós-acadêmica (Ziman, 1990), de um futuro sem disciplinas científicas (Gibbons et al., 1994), de sistemas nacionais de inovação (Nelson, 1993; Freeman, 1995), o modelo da hélice tripla (Etzkowitz \& Leydesdorff, 2000), entre outros. No entanto, trata-se de diagnósticos muito gerais, por vezes normativos, que pouco falam sobre a diversidade - e a desigualdade - na produção do conhecimento.

Nesta pesquisa, ao contrário, defende-se que a compreensão do processo de transformação da atividade científica pressupõe a realização de pesquisas que privilegiem os contextos nacionais e a diversidade de instituições. Trata-se de investigar os modos pelos quais as tendências globalizantes na produção científica geram heterogeneidade de resultados passíveis de serem observados empiricamente. Considera-se que, no processo de contextualização local das tendências globalizantes, elementos podem ligar-se de modos variados à tradição local de pesquisa, podendo tanto refrear como reforçar aspectos dessas tendências (Garcia \& Carlotto, 2012).

O recorte em uma área do conhecimento - a genética humana e médica - está baseado no pressuposto, largamente partilhado por uma vertente contemporânea da sociologia da ciência (Shinn \& Ragouet, 2008; Bourdieu, 2001; Kreimer, 2010; Gingras, 1991), de que a atividade científica não pode ser tratada de maneira uniforme, havendo configurações 
distintas de acordo com a área de conhecimento, o espaço disciplinar, a organização institucional e a tradição científica à qual se filia. Partindo dessas premissas, o eixo central desta tese consistiu na realização de uma pesquisa de campo detalhada e atenta à descrição de elementos pertinentes à atividade científica, suas instituições e práticas, em consonância com a recomendação de que, antes de fazer diagnósticos gerais sobre as transformações da ciência contemporânea, é necessário realizar estudos empíricos aprofundados para compreender o que está, de fato, acontecendo nos diferentes espaços disciplinares (Elzinga, 2002).

Relacionado a esses diagnósticos apresentados tem-se, também, a ideia da emergência e desenvolvimento de uma economia globalizada ou, simplesmente, globalização, e as consequentes mudanças para o sistema acadêmico internacional, fruto da pressão de adaptação em face das novas circunstâncias (Knight, 2008). As universidades, que sempre foram ambientes internacionais, sofreriam, assim, os impactos da globalização. Dessa constatação se desenvolve toda uma discussão sobre a internacionalização da produção científica e das instituições de ensino superior e seus respectivos programas de pós-graduação.

A "internacionalização da ciência" está na pauta das políticas científicas da maioria dos países, em documentos oficiais e nos programas de agências financiadoras ${ }^{3}$ (Ramos, 2014); encontrar formas de internacionalizar a pesquisa latino-americana tem sido uma preocupação e até mesmo uma obsessão desde a década de 1980 (Vessuri, Guédon \& Cetto, 2014). No entanto, esse termo, espécie de "conceito-ônibus", raramente exige maiores explicações ${ }^{4}$, e, apesar de seu uso crescente, é mobilizado em diferentes acepções por diferentes pesquisadores e formuladores de políticas públicas (Knight, 2008).

Fala-se em internacionalização para descrever novos tipos de arranjos no ensino superior, como instituições abrindo novos campi, filiais ou franquias em outros países, com a utilização de uma variedade de técnicas presenciais e a distância. Ou, ainda, para se referir à inclusão de uma dimensão internacional nos currículos e no processo de ensino3 Basta observar os sítios online, por exemplo, da Deutsche Forschungsgemeinschaft (DFG), equivalente ao CNPq na Alemanha, ou a própria página que recupera e acompanha o assim chamado Processo de Bologna, para constatar a centralidade desempenhada pela internacionalização na agenda do centro. No caso do Brasil, o programa Ciência sem Fronteiras, bem como diretrizes da Capes, explicitam cada vez mais a necessidade e a relevância que lhe são atribuídas.

$<$ http://www.dfg.de/en/dfg_profile/index.html $>;<$ http://www.ehea.info/> $>$. Acesso em 30 de maio de 2018.

4 Em documento da Capes apresentando os resultados de uma pesquisa sobre a internacionalização de programas de pós-graduação avaliados com nota de 3 a 7, as definições do que será avaliado são igualmente pouco específicas: "a internacionalização das IES [instituições de ensino superior] tem o potencial de transformar as vidas de estudantes e tem um papel cada vez maior para ciência através da intensa troca de conhecimento acadêmico, permitindo assim a construção de capacidades sociais e econômicas" (Capes, 2017 , p. 4). Mais à frente: "A internacionalização pode ser entendida enquanto um processo amplo e dinâmico envolvendo ensino, pesquisa e prestação de serviços para a sociedade, além de construir um recurso para tornar a educação superior responsiva aos requisitos e desafios de uma sociedade globalizada. É o estágio mais elevado das relações internacionais entre as universidades" (Capes, 2017, p. 4). 
aprendizagem, de modo a produzir cidadãos globais. Uma das pesquisadoras mais citadas como referência para discutir o tema da internacionalização do ensino superior, Jane Knight (2003, p. 2), define a internacionalização como um processo que ocorre em nível nacional, setorial, e institucional, no qual "se integra uma dimensão internacional, intercultural ou global nos propósitos, funções e oferta de educação pós-secundária”.

Em uma acepção mais restrita, internacionalização é visto como sinônimo de mobilidade internacional de estudantes, professores e pesquisadores. Milene Ramos (2018), por exemplo, analisando as políticas de internacionalização implementadas por programas de pós-graduação brasileiros de excelência - que receberam notas seis e sete na Avaliação Trienal 2010 promovida pela Capes - identificou a prevalência de uma concepção de internacionalização em que a mobilidade acadêmica para o exterior é vista como o principal mecanismo de acesso à experiência internacional. Em termos da política científica brasileira essa concepção se traduz em programas como o Ciência sem Fronteiras (Dutra \& Azevedo, 2016), e as modalidades de bolsa para doutorado-sanduíche, doutorado integral e pósdoutorado no exterior (Ramos \& Velho, 2011).

Outra acepção corrente, mais ligada à produção de conhecimento, toma como internacionalização a participação de autores de diferentes países em publicações científicas a coautoria internacional. Ou, ainda, a internacionalização como difusão internacional da produção científica, por meio da publicação de artigos em periódicos internacionais indexados $^{5}$, bem como, igualmente, a internacionalização entendida enquanto o impacto internacional das publicações, por meio das citações recebidas (visibilidade das publicações em bases de dados internacionais) (Sebastián, 2011).

Essa circulação de estudantes e pesquisadores não é algo novo (Karady, 2002), mas as viagens vêm se tornando cada vez mais um fenômeno institucionalizado, tanto que seus benefícios são dados como autoevidentes e políticas científicas em muitos países incluem o financiamento de temporadas no exterior. Para melhor compreender esses movimentos, é preciso levar em conta a hierarquia internacional. Imagens populares da globalização sugerem um processo que homogeneiza e equaliza a sociedade mundial, mas um olhar sobre essas viagens mostra que elas não vêm sendo nem aleatórias, muito menos uniformes, cristalizandose em determinadas rotas: os estudantes têm viajado principalmente para a América do Norte e alguns países da Europa (Schott, 1998; Connell \& Wood, 2002).

5 Correlatamente, há toda uma discussão recente sobre a "internacionalização dos periódicos", entendida em termos de indexação em bases de dados internacionais, mas também como publicação de artigos de autores estrangeiros (Meneghini, Mugnaini \& Packer, 2006; Bringel, 2015). 
É interessante constatar como, do ponto de vista de certo lugar no 'centro' do sistema, a dimensão da internacionalização é significativamente diferente. Tomando por base um grande survey sobre a profissão acadêmica internacional, financiado pela Carnegie Foundation, Philip Altbach (1997) analisa o fenômeno da internacionalização da ciência e da universidade a partir das percepções dos profissionais estadunidenses. É mostrado como, ao mesmo tempo em que as universidades estadunidenses nunca foram tão internacionalizadas formando 450.000 estudantes de outros países e empregando funcionários de todo o mundo -, seu professorado é o menos comprometido com a internacionalização, se comparado a outros países do survey, como Alemanha, Inglaterra e Japão. Apenas metade dos professores nos Estados Unidos sentem que conexões com pesquisadores de outros países são muito importantes. E, enquanto mais de $90 \%$ dos acadêmicos de outros 13 países ${ }^{6}$ acreditam que um pesquisador deva ler livros e revistas publicados no exterior, para acompanhar os desenvolvimentos acadêmicos, apenas $62 \%$ dos professores nos EUA têm tal opinião. Esse corpo docente considera que a educação superior nos EUA está no centro do sistema acadêmico internacional; o mundo vai para os Estados Unidos e, portanto, iniciativas de internacionalização são supérfluas.

Nesse sentido, se para muitos países da periferia a internacionalização da ciência é sinônimo de ir aos laboratórios e instituições de pesquisa dos centros, trabalhos como o de Altbach (1997) mostraram que, do ponto de vista dos centros, a internacionalização muitas vezes significa receber pessoas de outros países em suas universidades e laboratórios, e não viagens a esses países e mesmo colaborações com pesquisadores sediados no exterior. Em suma, a ciência e o universo acadêmico são estratificados e hierarquizados. Estas características, que podem ser observadas internacionalmente, bem como no interior dos sistemas universitários, diferenciam a profissão e são fatores importantes para as carreiras acadêmicas. Hierarquias nas disciplinas, combinadas com uma hierarquia de instituições, forjam um sistema de centros e periferias. Embora o acesso ao conhecimento venha sendo facilitado pelas novas tecnologias, a capacidade de participar do sistema permanece controlada pelas elites científicas nas várias disciplinas (Altbach, 1997).

Essa breve exposição visou mostrar como são múltiplas as definições - e as políticas de internacionalização e por isso defende-se, aqui, que o olhar sobre os processos de internacionalização da produção científica deve levar em conta a diversidade e a heterogeneidade das diversas áreas, além do contexto econômico, político, sociocultural e

6 Os países estudados no survey foram: Estados Unidos da América, Inglaterra, Alemanha, Holanda, Rússia, Suécia, Hong Kong, Japão, Coreia do Sul, Brasil, Chile, México, Israel e Austrália 
geográfico em que ocorrem as atividades científicas. Nesse sentido, é importante que seja feita uma reflexão aprofundada, que não se limite a procedimentos de quantificação da internacionalização da ciência, e que possa abranger, de maneira detalhada, aspectos fundamentais que perpassam os processos de internacionalização da ciência nacional, levando em conta as especificidades e singularidades locais.

É tão somente aprofundando-se em uma área específica que se pode enxergar o que de fato acontece, para além dos discursos de política científica. A escolha da área da genética humana e médica será melhor fundamentada mais à frente, destacando-se, desde já, que ela oferece um terreno fértil para essa análise detalhada. Isso se justifica, primeiro, pois com o desenvolvimento da pesquisa genômica, ela se torna uma área de ponta, relativamente bem financiada, tanto no Brasil quanto no exterior. Segundo, como será visto no primeiro capítulo, que discute a institucionalização da pesquisa em genética no país, trata-se de uma área que se desenvolve desde o início com fortes ligações com o internacional, o que permite verificar processos de internacionalização, o peso das dimensões locais e possíveis tensões do proclamado universalismo da ciência. Nesse sentido, a área aparece como um espaço privilegiado para ver a dinâmica das interações de saberes, pesquisadores, instrumentos e técnicas, e como isso ocorre concretamente.

$\mathrm{O}$ recorte em uma área específica permite escapar, também, às generalizações, que tendem a ser perniciosas, nos fazendo assumir que é possível encontrar (e replicar) receitas para a internacionalização. Numa era de forças globalizadoras que afetam a produção e a disseminação do conhecimento, as generalizações podem se tornar recomendações, que, por sua vez, acabam desembocando em políticas públicas ou institucionais com objetivos que dificilmente serão alcançáveis com fórmulas de uso geral (Medina, 2013).

Com base nas três inquietações descritas acima, elaborei meu projeto de doutorado de modo a investigar em mais detalhes o papel que a pesquisa brasileira, em uma área específica - a genética humana e médica -, ocupou e ocupa no cenário internacional, a partir da hipótese de que existiria uma divisão internacional do trabalho científico, levando em conta a discussão das assimetrias na produção do conhecimento científico, buscando não tomar como dado discursos sobre as transformações na produção do conhecimento, a globalização da ciência, e a internacionalização, aprofundando o olhar voltado aos processos concretos e cotidianos de produção e legitimação do conhecimento.

Concebe-se aqui a internacionalização da pesquisa e do ensino, e a divisão internacional do trabalho, não como dado, mas como objeto de análise. Para tanto, foram 
realizadas entrevistas com pesquisadores da área, bem como a análise de suas publicações. Interpretando os dados coletados em campo, é possível dizer que, ainda que esta tese continue refletindo sobre a divisão internacional do trabalho científico na área da genética humana e médica, pouco a pouco esse se tornou um tema secundário, sobretudo devido à riqueza do material coletado, que abriu espaço para novas questões.

O objetivo central desta tese passou a ser delinear e analisar as diversas dimensões da relação entre centros e periferias na produção e circulação do conhecimento, tomando como ponto de partida o campo brasileiro da genética humana e médica e suas diversas relações com o "internacional”, enfatizando as desigualdades globais na produção do conhecimento, mas, também, as diferentes estratégias mobilizadas pelos pesquisadores para tentar fazer frente a essa situação e produzir resultados relevantes. Tais dimensões da relação centro e periferia, como será detalhado mais à frente, dizem respeito a aspectos institucionais, como a infraestrutura para a pesquisa e financiamento, mas também a aspectos culturais, e àqueles propriamente intelectuais.

Busca-se discutir as razões, estratégias e contingências das colaborações internacionais realizadas pelos pesquisadores entrevistados e suas relações mais amplas com um cenário de pesquisa percebido como desigual. Em outros termos, compreender as representações que os geneticistas brasileiros estão fazendo de si mesmos, e de suas relações com colegas de outros países, como eles estão sendo representados por esses colegas, e como tudo isso está sendo estrategicamente negociado e renegociado nas atividades cotidianas. Busca-se, também, analisar a constituição de agendas de pesquisa, em consonância e tensão com os padrões e parâmetros da "ciência internacional". E, por fím, discute-se as possibilidades para o reconhecimento da pesquisa realizada pelos pesquisadores brasileiros em genética humana e médica, aprofundando-se a reflexão sobre a tensão entre o local e o internacional. Enfim, trata-se de esmiuçar um olhar voltado a interpretar a pluralidade e as facetas dessas relações entre centros e periferias, e a dinâmica por meio da qual as desigualdades globais na produção do conhecimento são postas, repostas e contestadas nesse espaço social em particular, a genética humana e médica brasileira.

A relação centro-periferia é usada aqui como um recurso analítico, de modo a enfatizar a relação assimétrica entre os diferentes contextos locais nos quais se desenvolvem as práticas científicas. Mesmo que se considere válida a ideia de um tipo de "República da Ciência", que atravessa e borra todas as fronteiras nacionais (Polanyi, 1962), isso não significa que todos os contextos locais possam ser considerados equivalentes no que diz respeito a sua inserção em 
uma "comunidade científica internacional" ideal. Ao contrário: faz-se evidente a existência de espaços socioinstitucionais e cognitivos que ocupam o centro do cenário no desenvolvimento de novos conhecimentos face a outros contextos cujo aporte à empresa científica parece bem mais marginal (Kreimer, 2010). Por certo, aceitar a existência de centros e periferias no contexto do desenvolvimento de determinado campo disciplinar não desfaz, de imediato, o nó conceitual acerca da análise da ciência em contextos periféricos. Busco, na seção seguinte, delinear, a partir da literatura teórica disponível, como se utilizará, nesta tese, os termos centro e periferia, noções já tão carregadas de sentidos e história.

\section{Centros e periferias na análise da ciência contemporânea}

A distinção entre centro(s) e periferia(s) é frequentemente mobilizada nos estudos latino-americanos sobre as relações entre ciência, tecnologia e sociedade. Ela está enraizada em uma longa tradição latino-americana, que inicia com os trabalhos de Raúl Prebisch, que a concebe nos anos 1950 para compreender a ordem econômica em escala mundial e explicar as desigualdades entre os países (Prebisch, 1949). Essa distinção foi revisitada pela teoria da dependência (Cardoso e Faletto, 1970, entre outros) e, a partir dos anos 1970, por diversos analistas de disciplinas diferentes, que estudaram o papel da ciência nos países latinoamericanos, e elaboraram uma série de proposições destinadas à utilização da ciência em favor do desenvolvimento econômico e social, e a favorecer a autonomia tecnológica necessária à industrialização dos países latino-americanos (Herrera, 1971; Varsavsky, 1976).

Wiebke Keim (2010), inspirando-se no trabalho clássico de Cardoso e Faletto (1970), propõe um modelo mais formalizado da distinção centro-periferia para a análise da disciplina sociologia. Os autores em questão distinguem três dimensões da inserção periférica das economias latino-americanas no mercado mundial - os problemas do subdesenvolvimento, da dependência e da marginalidade -, que são retomadas por Keim para formular, por analogia aproximada, seu modelo centro-periferia, de modo a olhar para a produção e difusão do conhecimento em sociologia. A primeira dimensão caracteriza a infraestrutura, a organização interna e o acesso aos recursos, enfatizando fatores extracientíficos necessários à produção de conhecimento. A segunda dimensão proposta caracteriza as condições de existência e reprodução das temáticas científicas, em que a periferia é notadamente caracterizada por sua dependência $v i s-\grave{a}$-vis as agendas de pesquisa definidas de maneira exógena pelo centro. A terceira dimensão, por sua vez, trata da posição e do reconhecimento internacional da produção científica de uma dada zona geográfica. 
A autora utiliza essas três dimensões da problemática centro-periferia para identificar, respectivamente, as sociologias "desenvolvidas" ou "subdesenvolvidas", em função de seus aspectos materiais, institucionais e de infraestrutura, fortemente marcadas por fatores extracientíficos; as sociologias "autônomas" ou "dependentes", no que diz respeito às suas condições de existência e reprodução; e as sociologias "centrais" e "marginais", de acordo com a posição no interior do espaço científico internacional ${ }^{7}$. Essas três dimensões enriquecem o modelo centro-periferia, ao diferenciar os determinantes materiais e institucionais, a formulação de estratégias científicas, e as estruturas de difusão e reconhecimento científico, e aparecem como pertinentes na análise da genética humana e médica na medida em que permitem organizar três elementos fundamentais para a relação centro e periferia: as assimetrias no que tange às condições materiais; as assimetrias no desenvolvimento de teorias, métodos e técnicas; e as imagens - ou reconhecimento simbólico - que as diferentes contribuições têm no cenário internacional da ciência.

A primeira dimensão evidencia a necessidade de certa base material, a existência de uma comunidade científica mais ou menos integrada, instituições de ensino e de pesquisa, um mercado de trabalho acadêmico, e financiamento para a pesquisa. As desigualdades dessa base material são o elemento mais tematizado nos estudos sobre as ciências nas periferias. As duas outras dimensões, porém, evidenciam que o desafio consiste não apenas em dispor de infraestrutura e financiamento, mas também em conseguir influenciar as definições e metodologias da ciência e do trabalho acadêmico, assim como os padrões de reconhecimento.

Nesse sentido, o par dependência-autonomia diz respeito ao prestígio das teorias e métodos advindos dos centros, da autoridade reconhecida a esses pesquisadores, do valor superior atribuído às publicações nas revistas de destaque; do ensino a partir de manuais escritos no centro. Trata-se da conformação a uma agenda da ciência formulada no centro, e da adoção dos mesmos objetos de pesquisa, na periferia. Alguns estudos, enfocando as ciências sociais, denunciam o que seria uma extrema dependência dos pesquisadores da periferia em relação aos países do centro (Hountondji, 1990; Gaillard, 1994). Um trabalho bastante citado na discussão sobre o que seria uma dependência científica da periferia - ainda no âmbito da produção do conhecimento em sociologia - é o de Alatas (2003). Também 7 O modelo proposto destaca os traços comuns entre os países do centro e entre os países da periferia, mas a autora enfatiza que isso não significa que esses conjuntos são homogêneos. Ao contrário, é possível encontrar uma grande diversidade, quando se olha para os casos concretos, tal como propõe-se fazer nesta pesquisa. Nesse sentido, a autora afirma que essas dimensões devem ser melhor compreendidas enquanto posições ideal-típicas, e, também, de combinações entre as três dimensões. Ou seja, um país não precisa estar no mesmo lado das três dimensões, como é o caso do Japão, por exemplo, que tem uma sociologia altamente desenvolvida, do ponto de vista institucional e de financiamento, mas que pode ser considerada marginal, do ponto de vista do reconhecimento internacional (Keim, 2010). 
inspirado nas teorias latino-americanas da dependência, o autor enumera algumas razões, entre fatores institucionais e intelectuais, que contribuiriam para a dependência acadêmica: dependência de ideias; dependência de meios de comunicação; de materiais e tecnologias de pesquisa; dependência de financiamento estrangeiro para a pesquisa e o ensino, entre outros. A dificuldade, em alguma medida, é que esses trabalhos muitas vezes aparecem como denúncia ou polêmica, existindo poucas investigações empíricas que permitam ilustrar a dependência, embora seja presença constante nos debates. Nesta pesquisa, a dependência é tomada como hipótese a ser verificada a partir da genética humana e médica brasileira.

O par marginalidade-centralidade descreve, segundo Keim (2010), as relações entre as comunidades científicas, e também a função que uma comunidade científica desempenha na produção global de conhecimentos. Alatas (2003) distingue três níveis do que seria uma divisão global do trabalho científico: 1) a divisão entre trabalho intelectual teórico e empírico; 2) a divisão entre trabalhos realizados em outros países e trabalhos realizados no próprio país; 3) a divisão entre estudos comparativos e estudos de caso isolados. Segundo o autor, essa divisão do trabalho opera como mecanismo de perpetuação da dependência acadêmica: as ciências sociais periféricas são vistas, no âmbito da hierarquia de conhecimentos globalmente aceita, como produzindo conhecimentos de baixo grau de abstração e de generalização, enquanto o centro mantém o monopólio da prestigiosa pesquisa comparativa e da elaboração de teorias generalizáveis, ou mesmo universais (Alatas, 2003).

No mesmo sentido, Hountondji (2006) afirma que, no processo da pesquisa científica, o estágio decisivo não é nem a coleta de dados, nem a aplicação dos achados em questões práticas, mas, antes, a interpretação da informação ainda crua, o processo de teorização geralmente realizado por meio de maquinário e métodos - dos dados coletados, e a produção de afirmações científicas. Segundo ele, o resultado essencial da atividade científica nos países do dito terceiro mundo seria a falta desse estágio intermediário, dessa operação de teorização: a coleta de dados, coleta de toda informação supostamente útil, é exportada para a realização do processo teórico/experimental e para a interpretação; em seguida, há uma aplicação parcial e limitada dos resultados obtidos pela pesquisa metropolitana a alguns problemas locais, o que frequentemente produz uma relação mecânica entre essas facetas. Com a independência, alguns desses elementos teriam mudado: vários setores da periferia não estariam mais exportando dados crus, porque o processo preliminar de tratamento dos dados ocorreria cada vez mais nos países periféricos; em alguns casos, todo o processo pode ser feito no local, em laboratórios bem equipados. Essa transferência geográfica da responsabilidade por um estágio 
da prática científica não colocaria fim ao monopólio da teoria do centro, apenas significaria que cientistas da periferia têm mais responsabilidades ao participar do processo, sem ter de deixar seus países de origem (Hountondji, 2006).

Kreimer (2006) aborda esse tema em termos de integração subordinada, em que os pesquisadores estão fortemente integrados com a ciência internacional, trabalhando em linhas específicas que constituem uma parte de problemas conceituais maiores, realizando estudos e experimentos que, sendo importantes para o desenvolvimento do problema, não implicam, por si mesmos, avanços significativos em termos conceituais ${ }^{8}$. Trata-se de um aprofundamento da deslocalização do trabalho científico, da qual tratou Hountondji (1990), cujo resultado é a transferência para a periferia de atividades científicas muito especializadas e que exigem alta qualidade técnica, mas que em última instância assumem um caráter rotineiro. A integração é considerada subordinada na medida em que a escolha das linhas de pesquisa, a visão geral do problema e, também, suas utilidades reais ou potenciais são produzidas com forte dependência dos centros de referência dos países centrais.

Outra dimensão do fenômeno da marginalidade é o fato de que acadêmicos do "terceiro mundo" são estimulados a tratar de assuntos cujo interesse se apresenta como primariamente do público dos países industrializados. Hountondji (1990) chama esse fenômeno de extroversão teórica ou sócio-teórica; o fato de que o conteúdo da produção científica seja orientado pelas expectativas de leitores potenciais, localizados no Norte. Para atender às necessidades dos pesquisadores do Norte, os pesquisadores do Sul devem apresentar dados originais, exóticos, o que o autor considera uma forma de localismo forçado.

Baseada na noção de extroversão, Keim (2011) realizou uma pesquisa a partir dos acadêmicos estrangeiros convidados a falar na École des Hautes Études em Sciences Sociales (França), entre 2001 e 2003. A autora mostra que a maior parte dos convidados da África, Ásia e América Latina apresentaram temas relativos ao seu país ou região de origem e que podem, por isso, ser considerados informantes, no vocabulário de Hountondji. Ao contrário, a maior parte dos convidados advindos de outros países desenvolvidos que não a França realizaram conferências sobre temas de caráter geral, teórico ou metodológico, abstraindo os contextos de origem de seus trabalhos. Há estudos empíricos que destacam, também, como muitas vezes se trata de uma escolha estratégica: é por meio do trabalho em temas específicos, locais, exóticos, que os pesquisadores da periferia nas ciências humanas esperam aumentar a sua visibilidade no cenário internacional (Waast, 2003; Medina, 2013). É possível afirmar que

$8 \quad$ Esse é um fenômeno que o sociólogo Gérard Lemaine (1980), inspirado em Thomas Kuhn, chamou de ciência hipernormal. 
o conceito de extroversão acentua também os elementos internos que fazem com que um local esteja voltado para o exterior, em oposição a teorias mais simplistas da dependência, que a definem como se exercendo basicamente de fora para dentro (Bringuel \& Domingues, 2015).

Baber (2003) buscou analisar empiricamente a diferença entre o localismo e a abstração, a partir do título de publicações em ciências humanas. $\mathrm{O}$ autor discute a divisão do trabalho intelectual - e um certo consenso de que haveria uma separação entre o trabalho "prático" ou "técnico" relegado aos cientistas sociais indianos e o trabalho "puro", “conceitual" ou "teórico" realizado pelos britânicos - a partir de títulos de livros e artigos de ciências humanas. Ele mostra que, em geral, os livros e artigos que analisam as sociedades não metropolitanas têm, no próprio título, a identificação do país ou região em que o estudo foi realizado; de outro lado, é muito difícil encontrar títulos que façam referência aos EUA, Reino Unido ou França, sinalizando que, quando se trata de olhar para essas sociedades, a localização e o contexto não importam, e seus resultados são presumidos como tendo significância universal e não unicamente local, expressando as hierarquias e desigualdades que marcam a produção do conhecimento. Nesse sentido, Baber (2003) conclui que o escopo das generalizações parece ser a principal diferença entre centros e periferias.

Quando se passa das ciências sociais para a genética humana, algumas dessas questões se complexificam, enquanto outras perdem a sua pertinência. Primeiro, se é possível afirmar que a internacionalização é um fenômeno relativamente recente nas ciências sociais - embora as peregrinações acadêmicas e a circulação internacional sejam marcas da ciência desde a Idade Média (Gingras, 2002) - o mesmo não pode ser dito das ciências naturais que, em países da América Latina, são criadas já com algumas características voltadas à internacionalização, como a publicação em revistas estrangeiras (Kreimer, 2006). Da mesma forma, a internacionalização do financiamento de pesquisa também é marcante para a institucionalização da pesquisa em genética no Brasil, como será visto no primeiro capítulo desta tese. A própria preocupação com a constituição de um campo autônomo de debate, publicação e reconhecimento, no interior das fronteiras nacionais, parece ausente nos debates dos geneticistas desde o processo de consolidação da área, embora essa questão seja complexificada no terceiro capítulo.

De toda forma, nesses trabalhos está presente, apesar da utilização de terminologias diversas, um modelo analítico que enfatiza a formação de centros e periferias, que estruturam práticas de pesquisa e reconhecimento, destacando os mecanismos que tornam a produção e a circulação do conhecimento um processo desigual, privilegiando determinadas comunidades 
acadêmicas em detrimento de outras. Os cientistas poderão ser participantes ativos na produção e legitimação do conhecimento, mas também poderão ver sua atividade limitada à apropriação local ou à reprodução desse conhecimento que outros produzem, podendo, ainda, ver os resultados do seu trabalho desqualificados ou desvalorizados, com base na definição, pelos centros, do que é uma contribuição interessante, inovadora e legítima para o conhecimento num dado domínio (Nunes \& Gonçalves, 2001).

As relações entre centro e periferia também estão presentes nos debates pós-coloniais, decoloniais, e nos chamados estudos subalternos, que vêm se destacando pelas suas propostas de descentramento da teoria e da modernidade. Trata-se de um movimento intelectual bastante amplo, heterogêneo, cuja discussão detalhada escapa ao escopo desta tese. Ele se apresenta como uma elaboração da crítica pós-colonial do pensamento moderno, inaugurada com a discussão de Said (1978) sobre o Orientalismo, cujos desenvolvimentos incluem a tentativa de provincializar a Europa (Chakrabarty, 2000), ou encontrar abordagens alternativas, como os projetos de indigenous knowledge (Akiwowo, 1988).

Por sua vez, em artigo tratando dos debates em torno da produção de teoria social na periferia, Bringel e Domingues (2015) realizam uma apresentação esquemática dessas correntes, e destacam algumas de suas contribuições convergentes:

o questionamento dos diferentes "legados" do colonialismo (culturais,
históricos, geográficos) e de suas formas de persistência na atualidade; o
horizonte normativo de construção de "epistemologias alternativas" que
questionam o caráter patriarcal, racista, capitalista e eurocêntrico da
modernidade e suas formas de conhecimento; a recuperação e visibilização
de experiências silenciadas; o restabelecimento de uma fronteira mais tênue
entre o objeto e o sujeito de estudo; a abertura a outros lócus de produção de
conhecimento, exterior às universidades, e a legitimação desses atores e
espaços (Bringel \& Domingues, 2015, p. 64).

Entre as diversas correntes, uma tem como foco a realidade latino-americana: trata-se de autores como Walter Mignolo (2000), Aníbal Quijano (2000) e Edgardo Lander (2005), os quais consideram que, após o colonialismo, regiões como a América Latina continuaram expostas à colonialidade do poder (em termos políticos e econômicos) e do saber (em termos epistêmicos). Os autores se concentram nas consequências epistemológicas desse fenômeno, buscando destacar a voz e o conhecimento das pessoas oprimidas cujo status cognitivo tem sido sistematicamente subestimado, dando origem ao fenômeno nomeado de colonialidade do saber. Em linhas muito gerais, esse debate assume que a distribuição do poder afeta a produção do conhecimento, mas a posição periférica da ciência latino-americana é considerada como um dado não problematizado (Medina, 2013). 
Nota-se, ainda, a influência do pensamento pós-colonial sobre a sociologia do conhecimento (Anderson \& Adams, 2008). John Law (2008), por exemplo, reconheceu que os estudos da ciência e da tecnologia se focaram excessivamente na observação e análise de laboratórios e processos de produção do conhecimento situados nos centros. Pesquisas recentes, influenciadas pela perspectiva dos estudos sociais da ciência, tentaram combinar essas abordagens com uma discussão centro-periferia (Medina, 2013). Mas, de modo geral, a crítica epistemológica dos sistemas de conhecimento ocidentais tem sido mais acentuada do que a investigação empírica da produção e circulação do conhecimento em contextos periféricos (Connell et al., 2017) e dos mecanismos que produzem centros e periferias. Defende-se, nesta tese, que tais questões abstratas ou programáticas sobre a globalização do conhecimento são passíveis de análise empírica, quando o olhar se volta para a prática concreta dos produtores de conhecimento, considerando que é a partir das práticas cotidianas que as relações internacionais são produzidas e reproduzidas.

Constata-se, na literatura, algumas críticas à utilização do modelo centro-periferia. L'Hoste e Hubert (2012), por exemplo, afirmam que, no que diz respeito à mobilidade científica, esse modelo produz uma dupla explicação estrutural: de um lado, a divisão centroperiferia é estruturante, explica a origem e a destinação dos fluxos científicos, assinalando que os pesquisadores se formam nas tradições científicas bem estabelecidas nos países centrais e, em seguida, retornam para os países periféricos para reproduzi-las - mas em uma posição subordinada no interior de dita comunidade científica. De outro lado, a divisão centroperiferia é reforçada por esses fluxos científicos: ao reproduzir as tradições científicas dos países centrais, a definição da agenda científica se alinha com aquela dos países centrais, sem levar em conta os problemas locais dos países periféricos. As sociedades periféricas não podem, então, se beneficiar das pesquisas que elas financiam (Kreimer \& Thomas, 2006).

Para escapar de explicações deterministas, os autores propõem uma inversão de perspectiva: no lugar de invocar a priori uma geografia mundial das ciências para explicar a produção e a circulação de conhecimentos, trata-se, principalmente, de partir de estudos empíricos, a fim de produzir uma geografia das ciências contextualizada, correspondendo mais ao ponto de vista dos pesquisadores (L'Hoste \& Hubert, 2012). Ao mesmo tempo, os próprios autores afirmam que não se trata de afirmar que a diferenciação entre centros e periferias na produção e circulação do conhecimento não exista, mas sim de olhar para os modos pelos quais os pesquisadores se apropriam dela para construir suas trajetórias profissionais. Trata-se menos de desconstruir os diferentes modelos de desigualdades globais 
nas ciências evocados até aqui, e mais de apostar que essa mudança de perspectiva pode alimentar e complexificar os modelos macroscópicos (L'Hoste \& Hubert, 2012).

Em artigo discutindo as colaborações internacionais entre pesquisadores sul-coreanos e ingleses, Hwang (2008) afirma que o modelo centro-periferia é muito dicotômico, e que existiria uma área cinzenta que não pertence nem ao centro, nem à periferia, destacando que é preciso olhar para essas relações como sendo mais mutifacetadas do que um modelo dual daria conta. Rigas Arvanitis (2011a) critica, igualmente, a utilização desse par conceitual, que, segundo ele, tentaria dar conta de todo o mundo na análise, ao buscar classificar todos os países nessas duas categorias, que é, para ele, uma empreitada fadada ao fracasso. Ao contrário, propõe as noções de "países hegemônicos" e "países não hegemônicos", que permitiriam uma abordagem mais múltipla que dual, a fim de superar algumas limitações da distinção entre centro e periferia, que segundo ele foi enfraquecida pela multi-polarização do mundo, nascida do colapso da União Soviética e da afirmação de grandes países emergentes, como a China, a Índia ou o Brasil. O objetivo da formulação "países não hegemônicos” seria, então, escapar dos estigmas que acompanham a noção de "países em desenvolvimento" pobreza, analfabetismo, pouco investimento e infraestrutura - e, ao mesmo tempo, destacar que esses países, apesar de não disporem de instrumentos financeiros capazes de agir sobre a tendência da produção de conhecimento, como os EUA e a União Europeia, ainda preservam certa margem de manobra sobre a sua própria produção de conhecimento, nas escolhas dos temas de pesquisa e dos parceiros com quem cooperar (Losego \& Arvanitis, 2008).

Discutindo as diferenças de produção, circulação e legitimação do conhecimento científico entre contextos periféricos e centrais no sistema global de ciência e tecnologia, Fabrício Neves propõe abordar a relação entre centro e periferia não em um nível estrutural, mas "no âmbito fenomenológico da prática científica e das expectativas consubstanciadas em discursos" (Neves, 2014, p. 558). Nesse sentido, a ênfase de sua análise do sistema biotecnológico brasileiro, partindo de Niklas Luhmann, volta-se a como a diferenciação centro-periferia estaria sendo utilizada pelas instituições científicas e pesquisadores como critério de observação, que organiza os contextos em que biólogos moleculares e engenheiros genéticos trabalham, diferenciando a ciência em organização de ponta/organização atrasada, pesquisa de fronteira/pesquisa convencional, valor global/valor local.

Para Neves (2014), centro e periferia se apresentam como pressupostos articuladores de distinções, que têm consequências práticas, seja por meio do reconhecimento explícito da excelência científica dos rankings de universidades e revistas, seja por meio de processos de 
seleção de temas de pesquisa, métodos e teorias, por exemplo temas como "doenças negligenciadas" e "agricultura tropical".

Defendeu-se que a diferença centro/periferia se inscreve como valor e, portanto, torna-se expectativa e prática. A reprodução de tal diferença tem como consequência a atribuição de valor incremental, local, periférico à produção cognitiva de determinados contextos do sistema da ciência e, por outro lado, valor paradigmático, exemplar, a outros. Admitiu-se assim um processo de endereçamento no sistema científico, produtor de diferenças entre teoria, métodos e produtos (Neves, 2014, p. 572).

Nesse sentido, Neves $(2014 ; 2017)$ propõe que, antes de discutir se centros e periferias existem concretamente ou se são construções ideológicas, trata-se de pensar essas distinções, e a dinâmica entre o local e o global, a partir de processos de centralização e periferização, enraizados nos contextos de prática científica. Os processos de centralização seriam aqueles em que se valoriza positivamente o conhecimento gerado, há expectativas de reconhecimento e circulação, e também tem-se expectativas de publicação, enfim, criam-se condições para a universalização de como fazer e do que produzir. Por sua vez, os processos de "periferização" seriam aqueles em que se atribui um valor negativo ao que se faz e como faz, o que conduz a expectativas de não-reconhecimento, não publicação, e de circulação restrita dos conhecimentos produzidos ${ }^{9}$. Tal proposta busca, justamente, deslocar a ênfase estrutural que os conceitos de centro e periferia possam evocar.

Entre críticas e tentativas de análise de uma geopolítica da produção e circulação do conhecimento, pesquisadores se utilizaram de diferentes terminologias. A título de ilustração, cito, aqui, desde as distinções como primeiro mundo e terceiro mundo, países desenvolvidos e países em desenvolvimento, metrópole e colônia - mesmo na análise contemporânea em que os processos de descolonização já haviam se dado -, passando por Ocidente e Oriente, Norte e Sul, até centro e periferia, países hegemônicos e países não hegemônicos e, mais recentemente, Sul global e Norte global ${ }^{10}$. Alguns desses termos, tais como países hegemônicos e não hegemônicos (Losego \& Arvanitis, 2008), conforme visto acima, foram elaborados justamente a partir de críticas ao que se considera um modelo centro-periferia muito dicotômico, o mesmo podendo ser dito da discussão sobre processos de periferização e

9 Neves (2017) intitula os processos de periferização de regime de administração da irrelevância, que têm quatro características principais: a referência posterior, a escolha do objeto (que frequentemente tem características como o exotismo e a submissão), o intercâmbio de pesquisadores (a mobilidade deles da periferia para o centro, que reafirma posições hierárquicas), e, por fim, a tradução assimétrica.

10 Raewyn Connell (2007) frequentemente utiliza o par Norte-Sul global para designar regiões ricas do Atlântico Norte (EUA, Canadá e Europa) e os países tidos como periféricos na geopolítica global, respectivamente). A inclusão do termo "global' remeteria não a uma geografia física, mas a uma geografia moral e estrutural que tem sido ampliada, para além dos processos sociopolíticos, à divisão internacional do trabalho acadêmico (Bringel \& Domingues, 2015). 
centralização (Neves, 2017), no intuito de fazer frente a uma abordagem tida como estruturalista e determinista da prática científica.

Como exposto acima, a distinção centro-periferia está enraizada em uma longa tradição latino-americana que discute as relações entre ciência, tecnologia e sociedade. Em um esforço de acompanhar essa tradição, são esses os termos mobilizados nesta tese, de modo a discutir a produção e circulação do conhecimento na área de genética humana e médica. Analisar a produção do conhecimento em termos de centro e periferia é levar em conta suas hierarquias e desigualdades, e evidenciar as diversas assimetrias - de financiamento, estrutura institucional, mas também assimetrias referentes à seleção de temas de pesquisa, e ao reconhecimento simbólico dos produtos e produtores do trabalho científico. Nesse sentido, as dimensões propostas por Keim (2010) para analisar a relação centro-periferia permitem ir além das desigualdades financeiras e de estrutura institucional para abordar aspectos de dependência e marginalidade, a partir da discussão sobre a pesquisa brasileira em genética humana e médica.

Ademais, a discussão detida de tais assimetrias se justifica porque foram, por vezes, neglicenciadas nos chamados estudos sociais da ciência e tecnologia, que, ao olharem para a produção e circulação, tenderam a ignorar as condições de trabalho da profissão acadêmica, ajudando a reproduzir a ideia de que a prática científica é mais ou menos homogênea por todo o mundo (Medina, 2013), obscurecendo as dinâmicas institucionais e as estratégias necessárias nos ambientes científicos que não estão estruturados da mesma maneira que no centro (Kreimer, 2016).

A constatação das assimetrias globais não pode velar, no entanto, a inegável heterogeneidade dos países tidos como periféricos, de um lado, e centrais, de outro, o que me faz recorrer ao uso dos termos no plural, referindo-me a "centros" e "periferias". Na prática, tanto a ciência dos centros quanto as das periferias são entidades heterogêneas, que incluem uma variedade de práticas. Tanto os centros quanto as periferias são, também, fortemente hierarquizados internamente, sendo possível encontrar as mesmas distinções no interior de uma região, de um país e mesmo de uma instituição (Shinn, 1980). Centros e periferias são, aqui, tomadas como noções relacionais, e não cartográficas - como é feito por alguns autores acima. Por isso, evito recorrer aos termos "Norte" e "Sul" - mesmo quando incluído o "global" -, que acabam por remeter, implicitamente, a uma geografia, que obscurece justamente a existência de periferias no centro, e de centros na periferia. 
Ao mesmo tempo, as assimetrias entre centros e periferias remetem à dimensão nacional da ciência que, apesar das tendências de internacionalização ou globalização, continuam a definir a atividade científica de maneira determinante (Crawford, Shinn \& Sörlin, 1993). Essa dimensão "nacional" ou "local" - termos aqui usados como sinônimos, em oposição à "internacional" ou "global" 11 - é de suma importância, e por vezes negligenciada em estudos discutindo as desigualdades na ciência. Ainda que a ciência contemporânea seja tipicamente concebida como um empreendimento internacional - e universal -, não se deve negligenciar que a configuração de campos de pesquisa possa variar consideravelmente entre locais, regiões e contextos nacionais (Merz \& Sormani, 2016). Nesse sentido, o primeiro capítulo desta tese busca, justamente, delinear as características do campo da genética humana e médica no Brasil.

Mobilizar as noções de centros e periferias não significa naturalizar as desigualdades, ou converter a distinção em uma explicação determinista única das diferentes trajetórias de países e campos científicos. Para que escapemos das armadilhas essencialistas dessas dimensões, é preciso considerar que "periférica" não é uma característica intrínseca a certos países, campos, ou pesquisadores, mas uma posição em uma relação que inclui, como elemento constitutivo, um centro a partir do qual novo conhecimento costuma ser irradiado. Tampouco a condição periférica significa aceitação acrítica de temas, teorias, conhecimentos e padrões formulados nos centros (Medina, 2013).

Se as relações entre centros e periferias foram frequentemente tratadas a partir da lógica difusão-recepção (Basalla, 1967), que supõe a existência de um centro que irradia o conhecimento para as diferentes periferias, entendidas como dimensões estáticas, nesta pesquisa a ênfase está no plano das relações que os pesquisadores inseridos em um e outro contexto estabelecem no decorrer do tempo, e por meio das quais vão se articulando (tanto no centro quanto na periferia) ${ }^{12}$. Por isso, o ponto de partida para a discussão das relações entre centros e periferias desta tese é a análise empírica das práticas dos produtores de conhecimento, do olhar para como tais pesquisadores se apropriam dessas relações para

11 Como será discutido no segundo capítulo desta tese, os termos "internacional" ou "global" aparecem como sinônimos de "central", "mainstream", conhecimento produzido na América do Norte e Europa.

12 O olhar sobre a difusão e a importação, dado pela história da ciência com foco fora da Europa e dos Estados Unidos, não se volta às conexões ou circuitos de práticas que ajudam a explicar a construção de conhecimento. A importância crescente dos estudos pós-coloniais na história da ciência passou a enfatizar a necessidade de histórias entrelaçadas [entangled histories], que exigem um foco na circulação de pessoas, tecnologias e materiais, e o reconhecimento de que as práticas de parceiros mais marginais ajudam a moldar o conhecimento e as práticas nos centros hegemônicos, revelando as contribuições, muitas vezes não reconhecidas, dos receptores de teorias, supostamente passivos e periféricos, produzidas em outros lugares (Suárez-Diaz \& Barahona, 2013). Nessa literatura, a ênfase está voltada, então, a aspectos de influência mútua e processos interconectados de co-construção. 
construir suas trajetórias profissionais. Isso significa olhar para os praticantes da ciência, bem como atentar a como os discursos de centro e periferia são organizados e reorganizados nos grupos de pesquisa, no cotidiano da produção de cientistas e de conhecimento científico (Traweek, 1992), delinear os processos, escolhas estratégicas, situações, relacionamentos, detalhes concretos por meio dos quais essas relações são produzidas e reproduzidas por aqueles que participam ativamente do processo de produção do conhecimento.

A abordagem das diferentes dimensões da relação entre centros e periferias, proposta nesta tese, busca mesclar a discussão sobre os fatores institucionais - e estruturais - e questões processuais, na produção e reprodução dessa relação. Tais abordagens, como procurei mostrar, não precisam ser entendidas como opostas, sendo que sua articulação permite acentuar tanto processos de dominação, vindos de fora, e características mais estruturais, tais como discutidas nas vertentes mais diretamente inspiradas nas teorias da dependência, quanto os elementos internos, de como se estrutura a vida intelectual no contexto local, e as decisões e escolhas dos pesquisadores nele situados.

Por fim, é preciso destacar que é difícil escapar a uma certa dimensão tautológica na tentativa da definição "objetiva" de centros e periferias. Se a centralidade, tal como propôs Keim (2010), diz respeito à visibilidade e ao prestígio que um pesquisador, região ou país detém no espaço científico internacional, as suas formas de identificação e mensuração índices de citação, fator de impacto, publicação em periódicos bem avaliados e reconhecidos, indexados em bancos de dados como o ISI Web of Knowledge - são parcialmente tautológicas, uma vez que esses bancos de dados são produzidos nos centros, para identificar centros e periferias, e acabam reforçando a distinção. Como destaca Fernanda Beigel (2013), esses bancos de dados não refletem a produção de conhecimentos em escala internacional, e sim uma porção dessas pesquisas, aquelas publicadas em inglês, sob as normas de um dispositivo de hierarquização do conhecimento, conduzido por grandes empresas editoriais, não sendo, portanto, instrumentos neutros de medição de prestígio científico universal, e sim instrumentos de dominação simbólica. É esse, entre outros motivos, que justifica a abordagem qualitativa das relações entre centros e periferias, delineada na próxima seção. 


\section{Metodologia e procedimentos de pesquisa}

Justificativa da escolha da área de genética humana e médica

É possível afirmar que a área da genética humana e médica conta, atualmente, com grande prestígio e legitimidade seja nos países desenvolvidos, seja no Brasil. Rogério Meneghini (2006), um dos criadores do projeto SciELO (Scientific Eletronic Library Online), realizou um estudo para identificar núcleos temáticos de excelência em pesquisa brasileira que tiveram maior impacto na literatura internacional, a partir da identificação dos artigos com um mínimo de 100 citações no período entre 1994 e $2003^{13}$. Uma das doze áreas de destaque foi a da genética humana e médica. Além de seu destaque internacional, a genética aplicada ao humano tem como outra característica relevante a de ser uma área incentivada pelas políticas científicas nacionais. Por exemplo, de maneira direta ou indireta, a genética humana e médica encontrou espaço em quatro Institutos Nacionais de Ciência e Tecnologia $\left(\right.$ INCT) ${ }^{14}$ : INCT em Células-Tronco em Doenças Genéticas Humanas (Instituto de Biociências, USP), INCT de Genética Médica Populacional (Hospital de Clínicas de Porto Alegre), INCT em Oncogenômica (Hospital A. C. Camargo), e INCT em Células-Tronco e Terapia Celular no Câncer (Faculdade de Medicina, USP/RP).

No estado de São Paulo, no âmbito da Fapesp, foram financiados alguns grandes projetos na área, como o Projeto Genoma Humano do Câncer, desenvolvido por 29 laboratórios de sequenciamento localizados no estado, entre 1999 e 2001 (Kimura \& Bahia, 2002) e o sub-projeto Genoma Clínico do Câncer, desenvolvido entre 2001 e 2005, financiado pela Fapesp e pelo Instituto Ludwig de Pesquisas sobre o câncer. Além desses grandes projetos, pesquisas na área estão presentes em ao menos quatro Centros de Pesquisa, Inovação e Difusão (Cepids) ${ }^{15}$ : Centro de Terapia Celular (Faculdade de Medicina, USP/RP), Instituto de Pesquisa sobre Neurociências e Neurotecnologia (Faculdade de Ciências Médicas, Unicamp), Centro de Pesquisa sobre o Genoma Humano e Células-Tronco (Instituto de

13 A base de dados usada foi a plataforma ISI (Institute for Scientific Information).

14 O Programa Institutos Nacionais de Ciência e Tecnologia é um programa do CNPq em parceria com a Capes/MEC, as Fundações de Amparo à Pesquisa, o Ministério da Saúde e o Banco Nacional de Desenvolvimento Econômico e Social (BNDES) e tem por objetivo estimular o desenvolvimento de pesquisa científica e tecnológica de ponta, associada a aplicações, para promover a inovação e qualificação em áreas prioritárias para o desenvolvimento regional e nacional.

15 Os Centros de Pesquisa, Inovação e Difusão (Cepids), apoiados pela Fapesp por um período de até 11 anos, têm por objetivo desenvolver pesquisa de ponta, básica ou aplicada, de caráter multidisciplinar, com impacto comercial e social relevante, contribuir para a inovação por meio de transferência de tecnologia e oferecer atividades de extensão para professores e alunos do ensino fundamental e médio e para o público em geral. 
Biociências, USP) e Centro Antonio Prudente para Pesquisa e Tratamento do Câncer (Hospital A. C. Camargo).

Do ponto de vista de uma pesquisa tida como mais aplicada, destaca-se o edital do então Ministério da Ciência e Tecnologia (MCT) e do CNPq, de 2010, para financiar projetos de pesquisa que "contribuam para o avanço do conhecimento, a geração de produtos e deem subsídios para a formulação, implementação e avaliação de ações públicas voltadas a atenção em Genética Clínica no SUS"16. Do ponto de vista da atenção à saúde, há alguns programas relacionados à genética médica, sendo o mais importante o Programa Nacional de Triagem Neonatal, instituído em 2001, cujo objetivo é diagnosticar recém-nascidos para alguns erros inatos do metabolismo e hemoglobinopatias. Em 2014, o Ministério da Saúde publicou a portaria 199, que cria a Política Nacional de Atenção Integral às Pessoas com Doenças $\operatorname{Raras}^{17}$. Com isso, o Sistema Único de Saúde (SUS) visa incorporar quinze novos exames para diagnosticar doenças raras e credenciar hospitais e instituições para o atendimento de pacientes portadores dessas enfermidades ${ }^{18}$.

Esses são alguns dos elementos que justificaram a escolha da genética humana para a realização da pesquisa sobre as relações entre centros e periferias na produção do conhecimento. De um lado, tem-se a ideia de um "caso exemplar", reconhecido como prioritário pela política científica. Procedimento de escolha semelhante é feito por Zuckerman (1977) ao olhar para os vencedores estadunidenses do Prêmio Nobel, entre 1901 e 1972, investigando suas carreiras, mostrando como as suas realizações científicas estavam conectadas a oportunidades e obstáculos moldados pelo sistema de estratificação da ciência e detalhando os processos sociais de acumulação de vantagens e recursos de seus ganhadores. Por essa razão, o Prêmio Nobel é uma maneira de olhar para as realizações científicas ideais, sendo ele um símbolo de prestígio máximo da ciência. Mais recentemente, Shinn e Marcovich (2009) estudaram os ganhadores do Prêmio Feynman de Nanotecnologia para poder identificar e discutir o que é considerado, entre os praticantes da pesquisa em nanoescala, como pesquisa de ponta e investigação promissora, ou seja, o que é visto como excelente, modelar, digno de recompensa e premiação. É nesse sentido que o suporte das agências de fomento aparece nesta pesquisa, como um indicador de legitimidade semelhante a uma 16 Edital MCT/CNPq/CT-SAÚDE $\mathrm{N}^{\circ}$ 57/2010. Disponível em: http://cnpq.br/chamadas-publicas? p p p id=resultadosportlet WAR_resultadoscnpqportlet_INSTANCE 0ZaM\&id $=75-32-$

$1204 \&$ detalha $=$ chamadaDetalhada\& filtro $=$ resultados. Acesso em $01^{-0}$ de maio de 2018.

17 O conceito de doença rara utilizado pelo Ministério da Saúde é o mesmo recomendado pela OMS, ou seja, é a doença que afeta até 65 pessoas em cada 100 mil indivíduos. $C f$. Portaria $\mathrm{n}^{\circ}$ 199: http://bvsms.saude.gov.br/bvs/saudelegis/gm/2014/prt0199_30_01_2014.html. Ainda que não trate exatamente de doenças genéticas, muitas dessas estão incluídas nessa definição adotada.

18 Essa política para doenças raras ainda está nos momentos iniciais de implementação. 
premiação que reconhece o valor do que foi realizado pela pesquisa anterior e a um estímulo para o desenvolvimento de novas realizações.

De outro lado, devido a sua dimensão mais aplicada, seja em termos de atendimento a pacientes, seja em termos de política pública de saúde em genética clínica, a área permite observar relações e tensões entre a "pesquisa de ponta" e a dimensão local ou nacional de sua produção e utilização. Em outros termos, trata-se de uma tensão entre um perfil mais voltado à pesquisa inovadora, com pesquisadores fortemente integrados em redes de colaboração internacional, que participam de programas de pesquisa e congressos internacionais, e outro perfil de produção de conhecimento mais ligado ao atendimento a pacientes, que busca responder às necessidades locais de conhecimento.

\section{Abordagem qualitativa, etapas e procedimentos de pesquisa}

Em termos de seus procedimentos, esta pesquisa é composta de três movimentos principais. Como ponto de partida, foi revisitado o tema da institucionalização da pesquisa em genética humana e médica, já inicialmente tratado em meu mestrado (Ferreira, 2013), porém enfatizando as relações com o internacional e processos de divisão do trabalho na história da área no Brasil. Para tanto, foi feito amplo levantamento bibliográfico sobre o tema, iniciado no mestrado e complementado no doutorado, acrescido da leitura de algumas fontes documentais, notadamente entrevistas com os "pioneiros" da genética brasileira, disponíveis em revistas como a Ciência e Cultura, organizada pela Sociedade Brasileira para o Progresso da Ciência (SBPC) e no arquivo do Centro de Pesquisa e Documentação de História Contemporânea do Brasil (CPDOC), que conta com entrevistas com cientistas brasileiros de várias gerações, realizadas no âmbito do projeto "História da ciência no Brasil", desenvolvido entre 1975 e 1978, coordenado por Simon Schwartzman, e financiado pela Financiadora de Estudos e Projetos (Finep).

Para a análise do processo de institucionalização da pesquisa em genética foi utilizado o conceito de tradição científica, como formulado por Pablo Kreimer (2010), que considera esse conceito um elemento-chave para a compreensão das dinâmicas locais na produção de conhecimentos, permitindo dotar a análise de historicidade, na medida em que uma tradição remete tanto à conformação intergeracional de redes de identificação, de práticas e enfoques comuns, quanto à atualização dessas dimensões no tempo presente.

Em seguida, de modo a traçar um quadro contextual apresentando os contornos no interior dos quais se realiza a pesquisa em genética humana e médica, foi feito um extenso 
levantamento dos pesquisadores/as que compõem a área em questão. A amostra que compõe o meu referencial de análise, de 381 pesquisadores/as, foi selecionada de forma manual. $\mathrm{O}$ primeiro procedimento consistiu em buscar nos sítios eletrônicos de todas as universidades federais e estaduais brasileiras a lista de professores/pesquisadores dos departamentos ou institutos de "biociências", "biologia", "genética", "biomedicina", "bioquímica", "biofísica" e similares, além das faculdades de medicina. Em paralelo, foi feito um levantamento no Diretório de grupos do CNPq, nos Programas de Pós-Graduação reconhecidos pela CAPES, em Institutos Nacionais de Ciência e Tecnologia (CNPq), nos Centros de Pesquisa, Inovação e Difusão (Fapesp), e nas listas de associados da Sociedade Brasileira de Genética e da Sociedade Brasileira de Genética Médica. Por fim, foi realizado o levantamento dos laboratórios de genética humana e médica localizados fora das universidades, principalmente em hospitais privados e públicos.

A pluralidade de fontes utilizadas se explica, principalmente, pela falta de trabalhos anteriores que sistematizaram essas informações, em suma, o não levantamento do "estado da arte" da pesquisa em genética humana e médica no país. Dessa forma, a diversidade de fontes de informações visou realizar um levantamento o mais abrangente possível, e que pudesse identificar os pesquisadores em todas as regiões do país.

Nem todas as universidades divulgam a lista de docentes de seus departamentos e, nesse caso, buscou-se obtê-las com seus coordenadores, recorrendo à consulta pessoal. Outra dificuldade é que parte desses sítios eletrônicos encontrava-se visivelmente desatualizada. Logo, ainda que a pesquisa tenha feito esforço considerável na busca desses profissionais, é provável que um número deles não tenha sido localizado, embora estejam efetivamente trabalhando em alguma instituição de ensino e pesquisa no país.

De posse dessas listas, foi feita a análise inicial de seus currículos disponíveis na Plataforma Lattes para identificar a área de atuação desses pesquisadores. Isso se tornou necessário porque muitas das universidades não têm departamentos mais especializados, como "departamento de genética", tornando-se imperativo identificar os pesquisadores que apresentavam maior proximidade com o objeto desta pesquisa. Com essa lista atualizada em mãos - que excluía pesquisadores em botânica, zoologia, genética animal, entre outros - foi necessário fazer nova seleção para identificar os pesquisadores em genética humana e médica. Optou-se por manter na amostra de pesquisadores apenas aqueles que identificaram expressamente "genética humana", "genética médica", ou "genética humana e médica" no campo "área de atuação" disponível na plataforma Lattes, ou que tenham identificado essa 
como a área de formação no nível de doutorado. Essa escolha é um tanto arbitrária porque, ainda que a disciplina permaneça no centro dos trabalhos contemporâneos de pesquisa, alguns dos eixos temáticos exigem uma abordagem que congrega outras disciplinas. Mais do que falar propriamente em interdisciplinaridade, nesse caso, lida-se com temas que podem ser tratados a partir de diferentes abordagens disciplinares ${ }^{19}$.

A forma de coleta dos dados impõe algumas limitações: a primeira é que os pesquisadores encontrados estão majoritariamente nas universidades públicas brasileiras, no nível federal e estadual. Devido à grande dispersão e diversificação das universidades privadas e confessionais, optou-se por excluí-las da pesquisa. A exceção se deu quando esses professores e/ou pesquisadores estavam ligados a grupos de pesquisa ou projetos com pesquisadores das universidades públicas ou foram expressamente mencionados nas entrevistas realizadas. Outra dificuldade, no que diz respeito às instituições privadas, é seu baixo comprometimento com a pesquisa, apresentando-se, na maior parte das vezes, como instituições de ensino, mais do que como instituições que sejam conhecidas como produtoras de conhecimento (Martins, 2009; Sampaio, 2011).

Chegou-se, então, a uma amostra de 381 pesquisadores(as), cujas características principais são desenhadas no primeiro capítulo desta tese. Em destaque estão informações sobre as trajetórias formativas e profissionais desses pesquisadores, distribuição regional e institucional, inserção departamental - se biologia ou medicina, e experiências internacionais de formação e/ou trabalho. Esses dados foram coletados dos currículos Lattes dos 381 pesquisadores(as) selecionados entre setembro de 2015 e janeiro de 2016, sendo complementados pelo acesso ao Portal da Transparência do Governo Federal, que contém informações sobre todos os servidores públicos em nível federal. Alguns desses dados foram atualizados em 2017, durante o trabalho de campo, quando novos nomes foram identificados, a partir das entrevistas realizadas, e inseridos na amostra.

A centralidade alcançada pela Plataforma Lattes decorre, em grande parte, da decisão tomada pelo $\mathrm{CNPq}$ de tratá-la como o formato único de apresentação de currículo nas chamadas públicas para a distribuição de recursos para a pesquisa - seja em forma de bolsas, seja em forma de auxílios diversos. Para operacionalizar essa unificação, os currículos são produzidos a partir de um formulário padrão, que deve orientar o preenchimento das

\footnotetext{
19 A pesquisa sobre o câncer é um bom exemplo. Em estudo discutindo a pesquisa em oncologia molecular no estado de São Paulo, Renan Leonel da Silva (2015, p. 192-193) mostra que os recursos advindos da Fapesp para esse tema foram distribuídos entre diferentes disciplinas: genética, bioquímica, medicina, imunologia, farmacologia e morfologia.
} 
informações consideradas relevantes para o processo de julgamento das solicitações de apoio ou, mais precisamente, de definição do valor da carreira desenvolvida pelo pleiteante.

Ainda que essa iniciativa tenha gerado protestos quando lançada, ela foi progressivamente aceita e, hoje, é praticamente inconcebível que um pesquisador atuante se permita "estar fora" dessa base de dados. Considerando que a Plataforma Lattes é o principal instrumento atual na pesquisa brasileira na busca por qualquer tipo de financiamento e que há pressões cada vez maiores para a atualização constante dos currículos, é possível afirmar que os dados apresentados no primeiro capítulo tendem a apresentar alta confiabilidade, sendo o contingente de currículos não recentemente atualizados bastante restrito ${ }^{20}$. Embora extenso, o formulário da plataforma tem um caráter limitado, pois define um conjunto finito de categorias de informações julgadas a priori como pertinentes para indicar o tipo de carreira desenvolvida até esse ponto pelo professor ou pesquisador. Entre essas informações, encontram-se dados sobre a formação acadêmica e a titulação, acompanhadas por data e instituição de origem de cada título, informações sobre vínculos profissionais e sobre a sua produção científica.

Apesar da aparente objetividade do formulário, a tentativa de utilizar as informações contidas nos currículos depositados na Plataforma Lattes para estudar os padrões de carreira dos acadêmicos brasileiros esbarra em uma dificuldade central, que é a variação no sentido que os pesquisadores dão a alguns itens. Assim, embora as informações que ali se encontram respondam aos itens de um formulário com opções pré-definidas e campos de preenchimento obrigatório, há certas liberdades que podem ser tomadas (Almeida, Moschkovich \& Polaz, 2012). São encontradas variações, por exemplo, em itens como a titulação, quando um professor utiliza a categoria "professor titular" para indicar que se encontra no estágio final da carreira de professor nas universidades públicas e outro o utiliza para indicar que é professor efetivo de alguma instituição ${ }^{21}$. O item reservado aos "prêmios e títulos" é também interpretado de maneiras muito diversas. Assim, para além do que se entende normalmente como prêmio (nomeação com júri explicitamente constituído para tal), são por vezes considerados como prêmios a solicitação de recursos atendida por uma agência de pesquisa, assim como a participação em programas de televisão ou jornais de grande circulação. Isso indica que, como qualquer fonte de pesquisa, os currículos reunidos na Plataforma Lattes

\footnotetext{
20 O grau de adesão é ainda mais elevado nos assim chamados "centros de excelência”, em suma, programas de pós-graduação bem avaliados. Isso porque a avaliação da Capes dá-se, primordialmente, a partir da Plataforma Lattes, provocando um outro tipo de pressão para a constante atualização dos currículos.

21 Essa foi uma das características que pode ser controlada por meio do Portal da Transparência, que permite identificar, de maneira atualizada, o nível de carreira em que se encontram docentes de instituições federais.
} 
devem ser objeto de um exame crítico e as informações ali contidas precisam ser contrastadas com outras obtidas em fontes diversas, o que foi feito nesta pesquisa, na medida do possível.

Como dito, os resultados desse levantamento são apresentados no primeiro capítulo da tese, dedicado, entre outras coisas, a apresentar o mapeamento do campo científico da genética humana e médica no Brasil, buscando elencar algumas de suas características institucionais e o conjunto dos diferentes agentes no interior do campo. O conceito de campo científico $^{22}$ remete, de maneira geral, a um conjunto de aspectos institucionais que lhe garantem existência, um sentido prático e coletivo. Tais elementos não são dados, mas sim construídos pelos agentes da pesquisa ao procurar garantir condições para desenvolver seu trabalho (Gingras, 1991). Considerando que a atividade de pesquisa é levada a cabo por agentes sociais com características particulares, a descrição da emergência dessa atividade supõe explicar a produção desse tipo de agente e sua relação com o campo científico.

O uso da noção aqui proposta é o de campo como um operador relacional, que permite olhar para as instituições e agentes em um espaço hierarquizado de produção e circulação de conhecimento científico em genética humana e médica. Ou seja, mais do que postular a existência real de um campo científico autônomo, visa afirmar a existência de um espaço simultaneamente social e cognitivo, no qual o conceito de campo permite observar as dinâmicas e mediações pelas quais as estruturas institucionais e as práticas concretas dos agentes se vinculam. De outro lado, supomos uma noção de um campo com fronteiras mais ou menos definidas, mas porosas, dotadas de uma estabilidade relativa e provisória, em que as representações culturais e os interesses dos agentes são mais amplos que a busca de maior autoridade, seja ela social ou cognitiva (Kreimer, 2016).

Algumas ressalvas adicionais precisam ser feitas. Tal como formulou Medina (2013), a teoria dos campos de Bourdieu pressupõe que a ciência é organizada da mesma forma, ao redor do globo, o que permite que as especificidades de cada local sejam ignoradas. As condições de produção do conhecimento na metrópole são implicitamente aceitas como normas que devem ser replicadas em outras partes. Como consequência, a circulação internacional do conhecimento não é percebida como um problema relevante, uma vez que ela responde aos mesmos imperativos: aquisição e reprodução do capital científico. Em sua 22 Bourdieu define da seguinte maneira o campo científico: "[um] sistema de relações adquiridas (em lutas anteriores), o lugar, o espaço de jogo de uma luta concorrencial, onde o que está em jogo especificamente é o monopólio da autoridade científica, definida de maneira inseparável como capacidade técnica e poder social; ou, se quisermos, o monopólio da competência científica, compreendida enquanto capacidade de falar e agir legitimamente (isto é, de maneira autorizada e com autoridade), que é socialmente outorgada a um agente determinado" (Bourdieu, 1975, pp. 91-92). A ciência aparece, desse modo, como um espaço essencialmente conflituoso e estratificado, cujo objetivo é o controle da autoridade científica ou, em outras palavras, uma disputa pelo capital científico. 
análise do campo acadêmico francês, Bourdieu (1984) mostra que a maior parte dos acadêmicos, das diversas disciplinas, não estudou no exterior e, por isso, não faz nenhuma análise ou estudo especial sobre o impacto da trajetória no exterior sobre os membros do campo, suas posições e capital acumulado. No entanto, essa dimensão assume importância na periferia, tal como será discutido nesta tese. Campos centrais e periféricos podem até ter os mesmos componentes estruturais, mas são diferentes no que diz respeito ao impacto e à influência dos estudos estrangeiros (Medina, 2013) e, sobretudo no que diz respeito às colaborações entre eles, como será analisado no segundo e terceiro capítulo desta tese.

Para lidar com essa assimetria entre campos centrais e periféricos Leandro Medina (2013), em sua análise sobre o campo da ciência política na Argentina, propõe uma classificação dos campos científicos, distinguindo-os entre campos institucionalizados e campos em rede, a partir de quatro critérios principais: 1) condições de entrada; 2) número de atores; 3) fontes de capital; e 4) grau de autonomia. Os campos institucionalizados têm condições restritas para a entrada, que implicam requisitos formais, como o doutorado na disciplina. Esses campos incluem uma grande quantidade de membros, e, principalmente, membros mais diversificados e especializados. Uma característica crucial dos campos institucionalizados é que a fonte do capital é local: os recursos materiais e simbólicos necessários para legitimar uma carreira se originam no próprio campo. Como consequência, os acadêmicos nesses campos só olham para além do seu contexto local quando querem realizar pesquisas empíricas em lugares distantes ou quando são especializados em uma determinada região. Por fim, campos institucionalizados expressam um alto nível de autonomia. Já os campos em rede, segundo Medina (2013), têm condições de entrada mais flexíveis, um número reduzido de atores, e raramente muito especializados. A fonte do capital em campos em redes geralmente vem dos centros, de campos científicos mais avançados, sendo um indício a preferência dos pesquisadores e administradores científicos desses campos a publicar em revistas dos centros, reconhecidas como conferindo maior prestígio e garantindo uma distribuição mais ampla da publicação e, consequentemente, uma circulação mais ampla do conhecimento produzido localmente. Finalmente, a autonomia em campos em rede é baixa porque a influência de outros campos - como a economia ou a política geralmente afeta os padrões de produção científica. As universidades são facilmente moldadas por clivagens políticas e o sistema de ciência e tecnologia depende das políticas provisórias que mudam de acordo com o clima político (Medina, 2013).

A maior parte dos estudos em sociologia da ciência tratou, segundo a classificação 
apresentada, de campos institucionalizados, predominantemente localizados nos países tidos como desenvolvidos. Os estudos empíricos em Estudos Sociais da Ciência têm focado, também, em laboratórios, centros de pesquisa, universidades, museus e outros espaços de pesquisa no mundo desenvolvido (Anderson \& Adams, 2008). Nesse sentido, esta pesquisa busca contribuir para o aumento dos conhecimentos e reflexão sobre campos periféricos, mas considera que os campos científicos das periferias, longe de conformar espaços homogêneos de produção de conhecimentos, são organizações fortemente segmentadas e em constante tensão (Kreimer, 2006). O estudo dos diferentes grupos de pesquisa - no interior de uma mesma disciplina ou área do conhecimento - busca colocar em primeiro plano o caráter heterogêneo dos campos de pesquisa localizados em contextos periféricos. Olhar para pesquisadores inseridos em diferentes contextos regionais e institucionais permite, inclusive, trazer nuances ao modelo centro-periferia.

De modo a poder aprofundar o tema da divisão internacional do trabalho científico e das relações entre centros e periferias na genética humana e médica, optou-se pela entrevista em profundidade como recurso fundamental. Diversos métodos e técnicas de pesquisa vêm sendo utilizados para estudar as relações entre centros e periferias, mas a predominância reside nos estudos que utilizam a bibliometria e a cientometria (Gaillard, 2010), com análises estatísticas de publicações em coautoria (Wagner, 2006) e dos padrões de citação (Schott, 1998). Ainda que esses estudos mostrem, no geral, padrões desiguais no que tange à produção do conhecimento em diversas áreas, esse tipo de estudo concede um papel destacado às grandes redes de pesquisa e neglicencia todo o trabalho de construção de polos locais de pesquisa e, sobretudo, não enfoca as práticas de pesquisa (Arvanitis, 2011b).

Estudos etnográficos foram - e continuam sendo - realizados, em análises da produção do conhecimento, principalmente a partir da obra Vida de Laboratório, de Latour e Woolgar (1997). Eles permitem a observação das dinâmicas da ciência, ao focar nas atividades diárias dos cientistas, a partir da observação em locais específicos, como laboratórios, museus e centros de pesquisa. No entanto, no que diz respeito às questões delineadas para esta pesquisa, a abordagem etnográfica tradicional dos estudos sociais da ciência apresenta dois problemas. Primeiro, mesmo que se passe dois anos em um laboratório realizando o trabalho de campo, esse tempo é curto para apreender algumas características estruturais e tendências do campo em que o laboratório está localizado (Kreimer, 2005), assim como as características mais estruturais das relações entre centros e periferias na produção e circulação do conhecimento. Segundo, estudos etnográficos, ao focar nas atividades diárias, 
raramente olham para a trajetória dos pesquisadores, as oportunidades e restrições com as quais eles têm de lidar.

O desafio, neste trabalho, era conectar as experiências dos pesquisadores envolvidos com o processo de circulação e divisão do trabalho científico aos padrões, tendências ou fatores estruturais mais gerais que influenciam essas experiências. Para essa abordagem, foram realizadas entrevistas qualitativas semiestruturadas, buscando reconstruir a trajetória de pesquisadores da área de genética humana e médica, enfatizando não apenas suas escolhas individuais, mas também a reconstrução dos intercâmbios sociais, colaborações de pesquisa, experiências internacionais, buscando conectá-las com o contexto de atuação profissional, seja em termos de instituição de trabalho, seja em termos do contexto brasileiro.

No entanto, o foco, nessas entrevistas, não foi a reconstrução das histórias de vida em um sentido mais clássico, mas relatos parciais nos quais a trajetória profissional é o eixo da narrativa. A ênfase na trajetória profissional - que inclui o processo de formação dos pesquisadores - justifica-se porque a produção e circulação do conhecimento pode ser considerada como resultado de decisões estratégicas feitas pelos pesquisadores no decorrer de suas carreiras (Medina, 2014). Em outras palavras, as relações entre centros e periferias na produção do conhecimento em genética humana e médica devem ser analisadas em relação às trajetórias intelectuais e profissionais daqueles que participam ativamente do processo.

A história de vida permite situar pessoas e processos, evitando a tentação de generalizações que não possam ser fundamentadas. As entrevistas possibilitam abordar, também, as motivações de fundo para a colaboração internacional, o que significa explicar que aspectos socioculturais a incentivam ou atrapalham e, também, permitem compreender diferentes estratégias no que tange à relação com o internacional, e às diferentes formas com que elas impactam a produção de conhecimento, em um contexto de recursos materiais e simbólicos - relativamente - escassos. Entende-se que essas entrevistas em profundidade são necessárias, também, para reunir dados sobre as percepções dos pesquisadores sobre o campo de que fazem parte e suas relações com outros pesquisadores. De certo modo, as entrevistas são um diálogo entre o pesquisador e o entrevistado, em que o último reflete sobre sua vida e sobre o campo da genética humana e médica como um todo ${ }^{23}$.

\footnotetext{
23 As experiências relatadas pelos pesquisadores são narrações no presente sobre o passado e elas o recriam de acordo com o lugar, a situação e os interesses do sujeito no presente, de modo que não podemos dar aos relatos estatuto de objetividade ou neutralidade, o que não quer dizer que devam ser tratados como discursos ideológicos. Esses relatos são importantes não para observar um passado inacessível de outro modo, mas sim porque permitem ver as influências das experiências vividas sobre a formação desses sujeitos e como eles as interpretam (Debert, 1986). As entrevistas permitem compreender a partir de que categorias do presente os sujeitos olham para o passado e para as suas trajetórias; ou seja, a entrevista exige a atenção não tanto para o passado, mas para a relação entre o presente e o passado.
} 
Seleção dos entrevistados e suas características

Foram aventadas duas possibilidades para a escolha de pesquisadores a serem entrevistados: a seleção amostral e aleatória de pesquisadores, ou a seleção de grupos de maior peso identificados no levantamento apresentado no primeiro capítulo. A primeira abordagem implica maior representatividade dos dados coletados, e uma possibilidade maior de falar em termos de "Brasil". Ao mesmo tempo, ela implica uma compreensão menor das especificidades regionais e institucionais. A segunda abordagem, em contrapartida, possibilitaria compreender em maior detalhe as especificidade regionais e, mais ainda, permitiria comparações mais densas no modo de fazer pesquisa, e no modo de inserção internacional da pesquisa, partindo da premissa de que o desenho institucional deixa marcas na organização do trabalho científico. Ao mesmo tempo, selecionar grupos com grande quantidade - relativa - de pesquisadores, significa deixar de fora aqueles pesquisadores mais marginais do campo da genética, inseridos de forma isolada em diferentes instituições na região Centro-Oeste, Norte, e mesmo Sudeste.

A segunda abordagem foi escolhida porque, tal como explicitado anteriormente, um dos objetivos do trabalho era analisar os detalhes e meandros das relações entre centros e periferias na área específica. Nesse sentido, foram escolhidos para as entrevistas pesquisadores de instituições diferentes, tendo em vista alguns critérios. Primeiro, tomando por base o relatório da Avaliação Trienal da Capes dos Programas de Pós-Graduação (20102012), divulgado em 2013, levantou-se os programas de excelência na área de genética ${ }^{24}$.

Tabela 1: Programas de Pós-Graduação em Genética, avaliados com nota 6 ou 7 (triênio 2010-2012) 25 $^{25}$

$24 \quad$ A genética humana e médica, pensada em termos institucionais, é considerada na tabela de áreas da Capes e CNPq como uma subárea, dentro da área genética, que por sua vez está na grande área Ciências Biológicas. Não há programas de pós-graduação exclusivamente nessa subárea, por isso o recorte na área de genética.

$25 \mathrm{Na}$ avaliação do quadriênio 2013-2016, disponibilizada no final de 2017, algumas dessas notas mudaram: o programa da UFRJ subiu de 6 para 7 e os dois programas da USP caíram de 6 para 5. Nesse momento, tanto os grupos já tinham sido escolhidos quanto o trabalho de campo realizado. 


$\begin{array}{lccc}\text { Nome do PPG } & \text { Instituição } & \text { Estado } & \text { Nota } \\ \text { Genética e Biologia } & \text { UFRGS } & \text { RS } & 7 \\ \begin{array}{l}\text { Molecular } \\ \text { Genética e Biologia }\end{array} & \text { Unicamp } & \text { SP } & 7 \\ \begin{array}{l}\text { Molecular } \\ \text { Genética e Biologia }\end{array} & \text { UFPA } & \text { PA } & 6 \\ \begin{array}{l}\text { Molecular } \\ \text { Genética }\end{array} & \text { UFMG } & \text { MG } & 6 \\ \begin{array}{l}\text { Ciências Biológicas } \\ \text { (Genética) }\end{array} & \text { UFRJ } & \text { RJ } & 6 \\ \begin{array}{l}\text { Ciências Biológicas } \\ \text { (Biologia Genética) }\end{array} & \text { USP } & \text { SP } & 6 \\ \begin{array}{l}\text { Ciências Biológicas } \\ \text { (Genética) }\end{array} & \text { USP/RP } & \text { SP } & 6 \\ \begin{array}{l}\text { Ciências Biológicas } \\ \text { (Genética) }\end{array} & \text { Unesp/ } & \text { SP } & 6\end{array}$

Fonte: Relatório Capes de Avaliação 2010-2012. Elaboração própria.

Por motivos de viabilidade da pesquisa, foram selecionadas inicialmente três instituições para a realização do estudo aprofundado, baseado em entrevistas. Primeiramente, foram escolhidos os pesquisadores situados na UFPA, única instituição da lista fora do eixo Sul-Sudeste e, como pode ser verificado no anexo 2 desta tese, terceira instituição em número total de pesquisadores da área de genética humana e médica. Em segundo lugar, escolheu-se o campus de Ribeirão Preto da USP, principalmente por ter sido o local de criação da primeira residência em Genética Médica no Brasil, em 1977, no Hospital das Clínicas. Além disso, ao contrário da UFPA, em que a maior parte dos pesquisadores da amostra estão situados no Instituto de Ciências Biológicas, na USP/RP a filiação institucional é, majoritariamente, o Departamento de Genética da Faculdade de Medicina ${ }^{26}$.

A escolha da UFRGS, cujo Programa de Pós-Graduação é nota 7, deu-se porque o programa em questão congrega duas linhas de pesquisa com grande destaque, uma de genética de populações e outra de genética médica. Além disso, o Serviço de Genética Médica do Hospital de Clínicas de Porto Alegre (HCPA) é um dos mais antigos e renomados do país, sendo desde 2004 um Centro Colaborador da Organização Pan-Americana da Saúde/ Organização Mundial da Saúde (OMS).

Concluídas as entrevistas nessas três instituições, sentiu-se a necessidade de realizar outro conjunto de entrevistas, porque no conjunto de dados obtidos até aquele momento,

\footnotetext{
26 A Faculdade de Medicina de Ribeirão Preto (FMRP) foi criada com financiamento da Fundação Rockefeller, cuja contrapartida exigida era a expansão do tempo integral, a formação de pesquisadores experimentais e criação de condições para a dedicação exclusiva à pesquisa (Marinho, 2001). Embora voltada à formação profissional em medicina, assumiu, desde a sua fundação, um perfil mais científico, com incentivo a pesquisa básica, para além da aplicada (Marinho, 2001; Carlotto, 2014).
} 
estavam sub-representados um perfil específico de pesquisador, aquele formado em medicina, que atende pacientes e realiza pesquisa em genética médica. Para suprir essa necessidade escolheu-se uma quarta instituição, a Unicamp, por ser o local do primeiro departamento de genética médica da América Latina, localizado em uma Faculdade de Medicina - ou seja, um caso raro de existência institucional de um departamento que não é apenas de "genética", como é o caso da FMRP, por exemplo.

Nas quatro instituições contatou-se os pesquisadores previamente selecionados na amostra geral e, após as respostas, foram feitas 46 entrevistas $^{27}$, o que corresponde a cerca de $70 \%$ dos contatos realizados. Todas as entrevistas foram realizadas durante o ano de 2017 . O grupo de entrevistados não é tido como uma amostra representativa (nem aleatória). Ao mesmo tempo, ele tem características similares a outros geneticistas brasileiros, apresentando diversificação suficiente para fornecer insights úteis à discussão sobre a divisão internacional do trabalho científico e relações entre centros e periferias. Se a amostra probabilística possibilita conhecer aspectos gerais de uma dada realidade social, o caráter exemplar e único da amostra não probabilística dá acesso a um conhecimento detalhado e circunstanciado da vida social (Deslauriers \& Kérisit, 2008).

Ao mesmo tempo, não sendo estatisticamente representativas do universo dos grupos de pesquisa brasileiros na área de genética humana e médica, essas instituições podem ser consideradas como exemplares das estratégias bem-sucedidas de inserção internacional. Ainda que a seleção não abarque toda a diversidade temática, geográfica e institucional da genética humana e médica no Brasil, os laboratórios escolhidos representam um espectro de expectativas e atitudes variadas a respeito de seu desenvolvimento e das oportunidades que oferecem. Nesse sentido, se o objetivo não é olhar para a ciência brasileira - nem para a genética brasileira - de forma totalizante, defende-se que o recorte escolhido permite discutir em termos mais gerais, para a área específica, as relações entre centros e periferias.

É possível falar em representativo no nível sociológico, e não morfológico ou estatístico. Assim, o problema não é quantas pessoas precisam ser entrevistadas, e sim quem são os entrevistados, como eles dão sentido a suas vidas acadêmicas e sua relação com o contexto social e material mais amplo. Nas quatro instituições buscou-se entrevistar pesquisadores com perfis distintos de idade, sexo e trajetória profissional, pesquisadores com fortes relações com colaboradores internacionais - identificadas via Lattes -, mas também

27 É importante destacar que nessas instituições buscou-se pesquisadores da área de genética humana e médica em diversos departamentos, não apenas naqueles de genética. $\mathrm{Na}$ Unicamp, por exemplo, foram entrevistados também pesquisadores - aqui entendido no sentido de inserção profissional, cargo de pesquisador - no Centro de Biologia Molecular e Engenharia Genética. 
pesquisadores com relações fracas ou inexistentes com profissionais para além de seu contexto local, bem como pesquisadores ligados tanto à biologia quanto à medicina. Foi justamente depois de constatado o baixo número de entrevistados detentores dessa última característica que se optou por realizar entrevistas também na Unicamp.

Finalizadas as entrevistas na Unicamp, o trabalho de campo foi encerrado, obedecendo o princípio de saturação: já havia conseguido variedade suficiente, tinha entrevistado pesquisadores de perfis distintos, e percebeu-se que entrevistas adicionais não forneciam informações que sugeririam novos temas de análise. Além disso, mesmo esta pesquisa tendo se situado em "centros de excelência" - escolhidos a partir da nota dos programas de pósgraduação -, foram entrevistados agentes dominantes e não dominantes no campo, pesquisadores premiados e reconhecidos, e aqueles ainda em início de carreira e que, por vezes, inclusive, não estão inseridos em programas de pós-graduação. De um lado, como um todo, esses entrevistados são vistos como o "topo" na produção do conhecimento em genética humana e médica, de outro, ressalta-se a heterogeneidade interna desses grupos, ainda que esta tese tenha se focado em identificar algumas tendências e padrões mais gerais, a partir das falas dos entrevistados, com enfoque voltado à descrição detalhada das diversas dimensões das relações entre centros e periferias, o que significa, também, uma busca permanente de semelhanças e diferenças, de modo a olhar para acordos e tensões.

Foram entrevistados 14 pesquisadores da UFRGS, 13 da UFPA, 10 da USP/RP, e 09 da Unicamp. Do total, 24 dos entrevistados são do sexo feminino e 22 do sexo masculino. 31 dos 46 pesquisadores têm experiência internacional de longa duração (mais de seis meses), 32 são formados em biologia, e 14 em medicina. Na tabela abaixa encontram-se alguns dados dos entrevistados, divididos por instituições, referentes ao gênero, à formação e se obtiveram ou não experiência internacional.

Tabela 2: Panorama dos entrevistados por instituição

\begin{tabular}{|c|c|c|c|c|c|}
\hline & \multirow[b]{2}{*}{ Homens } & \multirow[b]{2}{*}{ Mulheres } & \multicolumn{2}{|c|}{ Formação } & \multirow[b]{2}{*}{$\begin{array}{l}\text { Experiência } \\
\text { internaciona }\end{array}$} \\
\hline & & & Biologia & Medicina & \\
\hline UFPA & 8 & 5 & 10 & 3 & 6 \\
\hline UFRGS & 6 & 8 & 10 & 4 & 12 \\
\hline Unicamp & 1 & 8 & 6 & 3 & 5 \\
\hline USPIRP & 7 & 3 & 4 & 6 & 8 \\
\hline
\end{tabular}

Fonte: Plataforma Lattes.

Elaboração própria. 
Todos os entrevistados são doutores, ainda que nem todos tenham começado a trabalhar na universidade com o título em questão. 32 realizaram ao menos um pós-doutorado, seja no Brasil, seja no exterior. O grupo inclui desde aquele que publicou dez artigos em sua carreira até o que publicou mais de 300 . O quadro completo dos entrevistados está disponível no anexo 3 desta tese.

Na identificação de meus informantes, utilizei nomes fictícios - de modo a resguardar a identidade das/os entrevistadas/os -, e não números ou siglas, com o intuito de deixar claro que estamos lidando com falas de indivíduos, ainda que considerados pelas posições que compartilham como membros de uma dada categoria social, a saber pesquisadores de genética humana e médica em centros de excelência, e marcada também por diferenças de inserção institucional, formação e gênero. Ao mesmo tempo, é necessário ressaltar que as entrevistas são instâncias empíricas sociologicamente elaboradas que não se confundem com os indivíduos empíricos. Trata-se, antes, de uma construção analítica (Bourdieu, 1984), que seleciona um conjunto finito de propriedades significativas com o objetivo de produzir insights importantes sobre as relações entre centros e periferias, a partir da prática concreta e cotidiana dos pesquisadores.

\section{Roteiro e análise das entrevistas}

Ao elaborar o roteiro de entrevista (consultar anexo 1), busquei fazer um amplo quadro da participação no cenário internacional a partir de perguntas que lidavam com formação e treinamento em centros de pesquisa estrangeiros, experiência de trabalho e viagens, participação em conferências e redes de colaboração, trabalho - e divisão do trabalho - com colaboradores estrangeiros, e percepções sobre a inserção da pesquisa em genética humana e médica no cenário internacional. Foram feitas, também, perguntas relativas à formação local, ao cotidiano de trabalho e à participação no atendimento aos pacientes ou realização de aconselhamento genético, quando pertinente.

Embora tenha havido um conjunto de perguntas mais comuns a todas as pessoas entrevistadas, a condução das entrevistas não ocorreu de modo padronizado/estruturado, mas sim a partir dos relatos mobilizados pelos entrevistados, buscando, na medida do possível, manter o compromisso com a não-diretividade, na situação de entrevista. A maior parte das entrevistas foi realizada presencialmente, nas salas de trabalho dos pesquisadores, salvo quando estes mencionaram a preferência por conceder a entrevista a distância, por meios virtuais, o que aconteceu em três ocasiões. 
Desde as primeiras entrevistas surgiu um tema imprevisto: a pergunta sobre se a minha pesquisa havia obtido a aprovação do Comitê de Ética da USP e, consequentemente, se existia um Termo de Consentimento Livre e Esclarecido (TCLE) a ser entregue aos entrevistados. Esta pesquisa teve início em 2014, sendo que a resolução sobre ética em pesquisa nas Ciências Humanas e Sociais data de 2016. Nesse sentido, ela não seguiu os novos trâmites ainda em implementação - e não foi submetida à Comissão Nacional de Ética em Pesquisa (Conep). Não haveria tempo hábil para realizar a submissão do projeto de pesquisa à Conep e realizar o trabalho de campo, de modo que se negociou com os pesquisadores a elaboração de um TCLE especificando a maneira como as entrevistas seriam utilizadas nesta tese, a garantia do anonimato, e o retorno das transcrições para a verificação.

As entrevistas foram transcritas e inseridas no Software Atlas Ti para a análise qualitativa. Seguindo os procedimentos de codificação aberta da "teoria fundamentada" de Strauss e Corbin (2008), a análise envolveu a seleção de trechos das entrevistas, a criação de códigos e a codificação desses trechos - o que permitiu desagregar os discursos individuais e reagrupá-los em subtemas específicos -, a releitura desses códigos e a recodificação dessas passagens, a partir dos novos códigos criados a partir da releitura e da comparação. Ainda que já existissem alguns temas preestabelecidos no início da análise das entrevistas, como "experiências de divisão do trabalho" e "experiências de colaboração internacional”, esse procedimento permitiu refinar tais noções e identificar uma série de outros elementos nas entrevistas, complexificando a análise das relações e dinâmicas entre centros e periferias, tal como evidenciado nos dois últimos capítulos desta tese. Segundo Strauss \& Corbin (2008), os procedimentos de codificação permitem construir teorias em vez de testá-las, no entanto, não se pretendeu com esta tese a construção de uma teoria. O que esses procedimentos proporcionaram foi relacionar a codificação das entrevistas aos temas pré-selecionados na pesquisa, a criação de novas categorias a partir dos diversos momentos de codificação e, sobretudo, realizar afirmações e discussões sem se afastar dos dados. A sistematização das entrevistas possibilitou, por exemplo, abordar a incidência e a recorrência de valores e expectativas presentes nas falas e práticas dos pesquisadores das quatro instituições visitadas.

$\mathrm{O}$ recurso à abordagem qualitativa, como dito acima, tem por objetivo aprofundar processos ou fenômenos complexos, tal qual a relação entre centros e periferias na produção de conhecimento, enfatizando os diversos sentidos e tensões de um fenômeno social. O uso da entrevista é tido como um meio de aproximar-se do ponto de vista dos agentes sociais e de considerá-lo para compreender e interpretar as suas realidades. Ou, em outros termos, 
apreender os sentidos que os agentes conferem a suas condutas, a maneira como eles representam o mundo e como vivem a sua situação.

Mas a entrevista permite, também, coletar informações sobre as estruturas e o funcionamento de uma dada formação social, nesse caso, o campo da genética humana e médica. Não pensando a técnica numa concepção positivista, em que o informante descreveria o que de fato se passa em uma sociedade, mas como meio de acesso a reconstruções que permitem explorar diferentes facetas sobre o fenômeno e sobre a experiência dos agentes. Assim, analisa-se essas falas como reveladoras de condições das práticas de pesquisa em genética humana e médica e as relações concretas e simbólicas estabelecidas com o “internacional”. Nesse sentido, tal como o formulam Deslauriers e Kérisi (2008, p. 131), “o objeto por excelência da pesquisa qualitativa é a ação interpretada, simultaneamente, pelo pesquisador e pelos sujeitos da pesquisa; de onde a importância da linguagem e das conceituações que devem dar conta tanto do objeto "vivido', como do objeto 'analisado"”.

Para dar conta das questões até aqui delineadas, a presente tese está dividida em três capítulos:

O primeiro capítulo - A genética humana e médica no Brasil - tem como objetivo contextualizar e analisar o espaço da genética humana e médica no Brasil. Discute-se o processo de institucionalização da área no Brasil, as principais características do espaço presente da genética humana e médica, e, por fim, as relações entre a biologia e a medicina e entre a pesquisa e o atendimento a pacientes - na produção do conhecimento em genética humana e médica.

O interlúdio - Divisão internacional do trabalho científico na genética humana e médica - realiza uma aproximação ao tema da divisão internacional do trabalho, na área objeto do estudo, a partir da análise das contribuições de pesquisadores brasileiros em artigos escritos com colaboradores situados em outros países. Olhando para o que chamo de discriminação da autoria, disponibilizada em um conjunto de periódicos, em artigos de coautoria internacional, reflito brevemente acerca do aporte dado pelos pesquisadores brasileiros à empreitada científica publicada.

O segundo capítulo - Explorando colaborações internacionais: rumo à identificação de dimensões da relação entre centros e periferias - parte da exploração das falas dos pesquisadores, descrevendo suas motivações e estratégias para a realização de colaborações 
internacionais para delinear as diferentes dimensões das relações entre centros e periferias presentes na produção do conhecimento em genética humana e médica. Apresento e interpreto o sentido das falas dos entrevistados, que concebem seu cenário como uma periferia pensada em termos de falta.

O terceiro capítulo - Elementos e constrições da colaboração em pesquisa: aportes envolvendo a articulação e legitimação de uma agenda de pesquisa periférica - complexifica os achados do capítulo anterior e avança na compreensão da formulação de agendas de pesquisa em contextos periféricos, em articulação e tensão com os pares internacionais. Discuto, também, a inserção da pesquisa em genética humana e médica no cenário internacional, notadamente no que diz respeito às articulações discursivas para justificar e legitimar a agenda e os resultados das pesquisas realizadas no contexto local.

Finalmente, nas Considerações finais, sistematizo e articulo os resultados desta pesquisa, explicitando os principais aspectos que eles permitiram identificar, bem como questões que exigem maiores investigações.

Para finalizar essa introdução, é preciso destacar que o cenário descrito nos próximos capítulos pode estar diante de uma profunda mudança. As imagens e percepções sobre a produção do conhecimento em genética humana e médica foram elaboradas - na situação de entrevista - em um contexto de diminuição do financiamento da pesquisa, que os entrevistados viam com preocupação. Ainda assim, naquele momento, os laboratórios desses centros de excelência eram descritos como bem equipados e em condições - potenciais - de realizar pesquisas "competitivas". O que todos os entrevistados concordam, no entanto, é que se a situação atual do financiamento à ciência brasileira não se alterar, essa descrição não mais corresponderá à realidade, pois em uma área de ponta, de constante mudança tecnológica, a diminuição do financiamento pode ter consequências muito rápidas e profundas para a produção do conhecimento no nível local. Uma das características de campos em rede, tal como formulou Medina (2013), é justamente a baixa autonomia das políticas científicas nacionais, devida ao caráter provisório das políticas públicas para a ciência, que, acompanhando diretamente o clima político, dificultam a podem até mesmo comprometer continuidade institucional. Logo, talvez a mesma pesquisa que realizei, de 2014 a 2018 , se desenvolvida alguns anos à frente, poderia encontrar configurações, tipos de colaborações, definições de agenda de pesquisa, motivações e modalidades de inserção na comunidade internacional bastante distintas das apresentadas, discutidas e interpretadas nesta tese. 


\section{CAPÍTULO 1}

\section{A genética humana e médica no Brasil}

O objetivo deste capítulo é contextualizar e analisar o espaço da genética humana e médica no Brasil. Tal como explicitado na introdução, considera-se que a atividade científica não pode ser tratada de maneira uniforme, havendo configurações distintas de acordo com a área de conhecimento, o espaço disciplinar, a organização institucional e a tradição científica à qual se filia. Nesse sentido, o capítulo busca delinear as principais características do contexto nacional e as suas principais instituições, no que diz respeito à área em questão.

Para tanto, são feitos três movimentos principais. O primeiro movimento delineia um panorama da institucionalização da genética no Brasil, enfatizando os arranjos entre pesquisadores, universidade e agência de fomento. Busca-se mostrar como o início do desenvolvimento da genética no Brasil, por volta de 1940, conformou uma tradição local de pesquisa, que abrange desde a escolha de temas de investigação e desenvolvimento de práticas de pesquisa específicas às modalidades de colaboração, de divisão do trabalho, e de inserção da pesquisa brasileira no cenário internacional. Discute-se, também, o papel central de uma fundação estrangeira, a Rockefeller, na institucionalização da pesquisa em genética e alguns contornos iniciais de uma divisão internacional do trabalho científico na área.

O segundo movimento busca delinear as características do campo presente da genética humana e médica. São descritas as principais características da amostra de pesquisadores, cujo mapeamento e seleção foram descritos na introdução, notadamente seus trajetos formativos e profissionais, sua inserção disciplinar, sua distribuição geográfica e institucional, bem como as experiências de formação e trabalho no exterior. Trata-se, em resumo, de traçar um quadro contextual apresentando os contornos no interior dos quais se realiza a pesquisa em genética humana e médica.

Por fim, em um terceiro movimento, tem-se a discussão sobre as relações entre a biologia e a medicina na produção do conhecimento em genética, acompanhada pelas referências ao atendimento a pacientes. A pesquisa em genética médica e genética médica populacional se desenvolveu no contato próximo com os afetados por doenças de base genética, geralmente em hospitais, e no Brasil isso não é exceção. Depreende-se dessa consideração que o atendimento aos pacientes marca os modos de produção de conhecimento na área escolhida e que essa relação precisa ser explicitada. 


\subsection{A institucionalização da pesquisa em genética no Brasil}

No início do século XX, a genética despertou cada vez mais o interesse de cientistas e instituições de diferentes países. Pesquisando inicialmente a variação e hereditariedade em plantas, a genética logo começou a ser aplicada na pesquisa agrícola para o melhoramento de sementes e animais (Mayr, 1982). Nas primeiras décadas do século XX, a genética também foi usada na medicina, na eugenia, e na antropologia física para estudar hereditariedade, evolução e diferenciação racial em diferentes partes do mundo (Adams, 1990; Kevles, 1985).

No Brasil, os primeiros estudos genéticos foram realizados entre 1910 e 1920 nas escolas de agronomia, como a Escola Superior de Agricultura Luiz de Queiroz (ESALQ) e o Instituto Agronômico de Campinas (IAC), ambas localizadas no interior do estado de São Paulo. Estes institutos enfatizaram o ensino e a pesquisa - básica e aplicada - em genética vegetal e animal (Habib, 2010). Nesse momento, como em outros países, o movimento eugênico brasileiro também ajudou a promover a genética no país, a partir da discussão sobre hereditariedade (Stepan, 2005; Santos, 2012).

Ao longo dos anos 1930 e 1940, o financiamento das primeiras universidades brasileiras deu novo impulso às atividades científicas no país. Destaca-se, no debate historiográfico sobre o desenvolvimento da genética no Brasil, a criação da Cadeira de Biologia Geral, no curso de História Natural da Universidade de São Paulo (USP), em 193428, sob a direção do médico André Dreyfus, e a vinda ao Brasil, em diversas ocasiões, do biólogo russo, Theodosius Dobzhansky, com financiamento da Fundação Rockefeller (Araújo, 2004; Glick, 2003; Monte Sião, 2007; Schwartzman, 1979).

A pesquisa em genética - inicialmente na USP - expandiu-se significativamente a partir de 1940, especialmente com o estímulo da Fundação Rockefeller (Cueto, 1994; Marinho, 2001). O vínculo entre essas duas instituições, durante os anos 1940 e 1950 período crucial para a institucionalização da pesquisa em genética no Brasil -, deve ser compreendido, segundo Marinho (2001), como desdobramento da associação anteriormente estabelecida a partir da Faculdade de Medicina, cuja origem remonta a 1915, data em que foram estabelecidos os primeiros contatos com membros da elite científica de São Paulo, com o objetivo de estudar as condições gerais de saúde pública e ensino médico da região. Os objetivos eram a implantação de um amplo programa de combate a doenças endêmicas e a

28 O curso de História Natural da USP começou a funcionar em 1935 e integrava disciplinas biológicas e geológicas congregando os seguintes departamentos: mineralogia e metrografia, geologia e paleontologia, biologia geral, zoologia, botânica e fisiologia geral e animal; ele permaneceu com esse nome até 1957, quando foi desmembrado em Ciências Biológicas e Ciências Geológicas (Mendes, 1994). 
identificação de centros de ensino médico, dispostos a implantar disciplinas de higiene e saúde, que pudessem ser apoiados pela Fundação (Marinho, 2001, pp. 54-58).

Como desdobramento desses primeiros acordos tem-se, a partir de 1928, um deslocamento da política filantrópica da Fundação, que passa a apoiar cada vez mais a implantação e manutenção de grupos de pesquisa na área de ciências naturais. Esse deslocamento de foco da Fundação Rockefeller beneficiou diretamente a institucionalização de grupos e linhas de pesquisa em genética.

Em 1942, André Dreyfus foi contatado pela Fundação Rockefeller por meio de um de seus funcionários em visita ao Brasil, Harry Miller Jr., assessor e diretor associado da Fundação nas áreas de medicina e ciências naturais na América Latina, e um promotor da genética e biologia evolutiva na América Latina (Glick, 2003; Salzano, 1991). Crodowaldo Pavan, um dos pioneiros da genética brasileira, menciona em uma entrevista que, ao visitar a Faculdade de Filosofia, Ciências e Letras (FFCL), Miller colocou à disposição de Dreyfus uma bolsa de pós-graduação nos Estados Unidos, de duração de um ano, para realizar pesquisa em laboratório e ministrar alguns cursos. Nas palavras de Pavan, um dos pioneiros:

Miller, que desde logo sentiu as possibilidades de um bom trabalho no laboratório e o indiscutível talento do Dreyfus, ofereceu a este uma bolsa de estudos nos Estados Unidos, mas com uma condição - Dreyfus deveria passar lá pelo menos um ano. Dreyfus ficou muito entusiasmado com o convite, mas no dia seguinte informou ao Miller que não poderia se ausentar durante tanto tempo do laboratório. Miller disse, então, que nesse caso ele poderia substituí-lo por um professor de origem russa, que estava na Universidade de Columbia. Esse professor estava empenhado em fazer pesquisas na América Central. Declinou o nome — "trata-se do Theodosius Dobzhansky". Ora, o Dreyfus ministrava seu curso baseado num livro de Dobzhansky, por isso imediatamente replicou: "Se o Dobzhansky pode vir ao Brasil, não necessito ir aos Estados Unidos”. Assim, Dreyfus perdeu uma excelente oportunidade de terminar sua formação no exterior, mas, em troca, gerou um fato de incalculável significado para o desenvolvimento da Genética no Brasil (Estudos Avançados, 1993, p. 193).

O geneticista Theodosius Dobzhansky foi, então, escolhido para desenvolver um programa de cooperação científica com o grupo de cientistas da USP, que veio a ser conhecido como Escola tropical brasileira de genética ou a escola de genética DreyfusDobzhansky (Formiga, 2007, p. 43). De origem russa, Dobzhansky tinha se estabelecido nos EUA na década de 1920, onde ensinou na Universidade de Columbia, com o grupo de Thomas Hunt Morgan, na época um dos centros mais importantes do mundo para a pesquisa em genética. Este grupo foi pioneiro no uso de drosófilas como modelo em estudos genéticos (Kohler, 1994). Dobzhansky tem seu nome relacionado à "Teoria Sintética da Evolução" - ou 
neodarwinismo -, movimento no interior da biologia que procurou integrar diversas disciplinas da área biológica, durante o período entre guerras (Araújo, 2006, pp. 7-8).

Com o convite da Fundação Rockefeller para ir ao Brasil, Dobzhansky viu uma oportunidade de ampliar seu programa de pesquisa, podendo incorporar as espécies de drosófilas de ambientes tropicais em seu trabalho, pois muito pouco se sabia sobre a estrutura das populações naturais nos trópicos. Não é por acaso que em sua primeira visita ao Brasil, além das atividades na USP, foi organizada uma expedição para coleta de drosófilas, e que a primeira atividade do grupo formado na USP foi a descoberta e catalogação das novas espécies (Ferreira, 2013). Em suas viagens, especialmente em 1943 e entre 1948 e 1949, Dobzhansky realizou algumas expedições científicas ao interior do país, particularmente à Amazônia, para a coleta e análise de espécies selvagens de drosófilas (Souza \& Santos, 2014). Nesse sentido, é possível afirmar que a vinda para o Brasil era importante, do ponto de vista das intenções e planos de pesquisa do biólogo russo, podendo se falar em uma combinação de interesses, cujo resultado foi a aceleração do desenvolvimento da pesquisa em genética no Brasil e a possibilidade de estender o programa de pesquisa em populações selvagens de drosófilas para além daquelas provenientes de ambientes temperados (Ferreira, 2013).

Em estudo discutindo a importância da Fundação Rockefeller para a emergência da genética no Brasil, Thomas Glick (2003, pp. 151-152) estabelece três fases para a Escola de Genética Dreyfus-Dobzhansky: 1) O período de 1943-1947, no qual são iniciadas as atividades de discussão sobre a obra de Dobzhansky e a introdução de metodologias científicas, mais precisamente a da pesquisa com drosófilas; 2) O período de 1948-1949, considerado a fase experimental, iniciada com a segunda visita de Dobzhansky ao Brasil, quase toda devotada a estudar a genética das populações de duas espécies de drosófilas brasileiras; 3) O período de 1950-1956, durante o qual seria realizado um segundo projeto de pesquisa envolvendo uma rede de pesquisadores sobre temas relacionados à drosófila, e no qual se observa a criação de outros centros de pesquisa em genética no Brasil.

Durante esse período, a Fundação Rockefeller não só aumentou o seu apoio ao Departamento de Biologia da USP, mas também financiou estadias de pesquisadores de outros países e estados brasileiros para treinar com Dobzhansky e Dreyfus, como Antonio Cordeiro e Francisco Salzano, de Porto Alegre, Chana Malogolowkin, Oswaldo Frota-Pessoa e Laden Cavalcanti, do Rio de Janeiro, Hans Burla, de Zurique, e Martha Wedel, de Buenos Aires (Glick, 2008, p. 318). Nesse grupo estavam jovens cientistas que, posteriormente, fundariam laboratórios de genética Brasil afora. Como exemplo temos os centros de genética criados na 
Universidade do Brasil (Rio de Janeiro) e na Universidade do Rio Grande do Sul (atual UFRGS), a partir de estágios de pesquisadores dessas instituições na USP, durante a estadia de Dobzhansky (Oliveira, 2015). A Fundação financiou, também, equipamentos para o estabelecimento e manutenção desses laboratórios. Sob a orientação de Dobzhansky, esse grupo se especializou em genética de populações, com destaque para o estudo da variabilidade biológica de diferentes espécies de drosófila (Araújo, 1998; Salzano, 1991).

Após a década de 1950, a genética brasileira se consolidou com grupos de pesquisa sendo estabelecidos em várias regiões do país, muitos deles dedicados à pesquisa com drosófilas (Santos, 2012). Foram criados, primeiro, laboratórios e departamentos de genética. Mais tarde, foram criados os cursos de pós-graduação. Entre 1940 e 1960, a Fundação Rockefeller também financiou viagens de geneticistas brasileiros para completar a formação, após o doutorado, em universidades estadunidenses (Glick, 2003; Salzano, 1991), notadamente na Universidade de Columbia.

Além dos recursos de agências internacionais, a partir de 1950 o governo brasileiro passa a investir mais no desenvolvimento da ciência, com a criação do Conselho Nacional de Pesquisa (hoje, Conselho Nacional de Desenvolvimento Científico e Tecnológico - CNPq), da Coordenação de Aperfeiçoamento de Pessoal de Nível Superior (CAPES), bem como da Sociedade Brasileira para o Progresso da Ciência (SBPC). Essas instituições passariam a ter um papel fundamental na organização e promoção da ciência brasileira (Schwartzman, 1979).

Continuando esse processo, em 1955, foi fundada a Sociedade Brasileira de Genética (SBG), reunindo um grande número de geneticistas. Com o contínuo apoio da Fundação Rockefeller, que inclusive financiou a organização da SBG, a genética foi um dos ramos da ciência brasileira que mais rapidamente cresceu (Salzano, 2011). A criação de associações científicas é parte constitutiva do processo de institucionalização da ciência (Merton, 1970; Ben-David, 1974), e, nesse sentido, é possível afirmar que a própria criação da SBG é marco fundamental, considerando a importância que teve para a consolidação, controle e difusão da área, por meio do estabelecimento de reuniões, congressos (como o Congresso Brasileiro de Genética, que teve início em 1956), publicações e prêmios.

Tem-se também como elemento fundamental da institucionalização a produção científica especializada e a criação de veículos para a sua publicação. Ainda que desde o início a produção dos pesquisadores em genética tenha sido marcada pela publicação em revistas internacionais (o que foi facilitado pela colaboração de pesquisadores estrangeiros 
como Dobzhansky), foram criados periódicos nacionais, como a Revista Brasileira de Genética, que existe até hoje com o nome de Genetics and Molecular Biology.

\subsubsection{Da escola tropical à genética humana}

Com a expansão teórica e metodológica e a consolidação da biologia evolutiva nas primeiras décadas do século XX, especialmente com um número crescente de investigações sobre as populações de animais e plantas, os pesquisadores começaram a aplicar o estudo dos processos evolutivos à espécie humana. No Brasil, segundo Vanderlei Sebastião de Souza e Ricardo Ventura Santos (2014), a mudança em direção à genética humana pode ser explicada por uma série de fatores. Primeiro, havia o interesse na constituição biológica da população brasileira, que era vista como amplamente miscigenada, de um lado, mas com um grande número de grupos considerados geneticamente isolados, como certas populações indígenas, de outro. Um segundo aspecto está relacionado à demografia do país, incluindo a alta migração, as taxas de natalidade e mortalidade, que foram fatores importantes para pesquisas sobre processos microevolutivos da população humana. Um terceiro fator seria uma longa tradição intelectual e científica no Brasil que considerava a "questão racial” e os problemas de saúde pública como os grandes dilemas da formação do país (Souza \& Santos, 2014, p. 100).

Algumas pesquisas relacionadas à genética humana foram feitas no Brasil entre $1925 \mathrm{e}$ 1950 por pesquisadores isolados, com publicações esporádicas, em revistas de divulgação restrita (Ferrari, 2006, pp. 323-324). Entretanto, tais pesquisas, apesar de seu valor na época, não foram consideradas como marcos do desenvolvimento da genética humana no país, pois esses autores não tinham a genética como seu principal interesse e não influenciaram outros pesquisadores a ponto de estimular a criação de tradições científicas voltadas para a exploração de problemas da genética na espécie humana (Beiguelman, 1979-80, p. 275). Nesse sentido, considera-se a década de 1950 como o momento em que a área de genética humana se institucionalizou no país (Frota-Pessoa, 1989, p. 458).

Fazendo uma breve reconstituição da história da genética humana, um pesquisador da área aponta alguns fatores que contribuíram para que houvesse certo desinteresse pela área antes de 1950: o compromisso dos principais centros de pesquisa com estudos de melhoramento vegetal e com pesquisas de genética de drosófila; a influência da eugenia e da propaganda nazista nas décadas de 1930 e 1940, que desestimulou o estudo de genética na espécie humana em diversos países, incluindo o Brasil; e a falta de cursos de bioestatística nos 
centros de pesquisa no país, que fazia com que poucos pesquisadores conseguissem compreender o que estava sendo pesquisado no exterior (Beiguelman, 1979).

A primeira geração da genética humana brasileira foi constituída majoritariamente por pesquisadores oriundos do estudo de drosófilas, discípulos de Dreyfus e Dobzhansky. Esse é o caso de Newton Freire-Maia (UFPR), seguido por Oswaldo Frota-Pessoa (Universidade do Brasil e, posteriormente, USP) e Francisco Mauro Salzano (UFRGS). As exceções dessa primeira geração ficaram por conta de Pedro Henrique Saldanha (USP) e Cora de Moura Pedreira (UFBA), que não tiveram uma fase de pesquisa com drosófilas, nem foram discípulos de Dobzhansky e Dreyfus ${ }^{29}$ (Ferrari, 2006).

O intercâmbio entre a geração de brasileiros especializados em drosófila, quase todos treinados por Dobzhansky, e geneticistas americanos influentes, como James Neel e Newton Morton, também foi decisivo no desenvolvimento da genética humana no Brasil (Souza \& Santos, 2014). Com bolsas de estudos da Fundação Rockefeller, jovens geneticistas brasileiros foram para a Universidade de Michigan, para estudos de doutoramento ou pós-doutoramento com James Neel, um dos principais nomes da genética humana nos EUA ${ }^{30}$ (Lindee, 2001; Salzano, 2000). Francisco Salzano, por exemplo, que se formou no Instituto de Ciências Naturais da UFRGS e estagiou na USP, pouco depois de seu bacharelado, em 1950, iniciou um processo de migração para a genética humana, interesse que se consolidou com a sua permanência, durante um ano, na Universidade de Michigan, com bolsa da Fundação Rockefeller (Beiguelman, 1979; Ferrari, 2006). Em entrevista, Salzano comenta esses anos de apoio da Fundação Rockefeller:

O Neel já tinha recebido o Barbosa Viana, que estava mais interessado em Genética Matemática; tinha aceito o Newton Freire Maia, como bolsista, quando ele escreveu dizendo que eu poderia ir. Quando fui, o Newton já estava lá há três meses, e isso ajudou muito em termos de adaptação nos Estados Unidos. Além do que, os membros da Rockefeller davam muito apoio e ajudavam muito os bolsistas (...). Fiquei lá de setembro de 1956 a setembro de 1957. Voltei para iniciar pesquisa na área de Genética Humana, e me dediquei a fundo, durante todos esses anos (Salzano, 2010, p. 7).

$\mathrm{Na}$ década de 1960, alguns pesquisadores brasileiros também completaram seus estudos de doutorado na Universidade do Havaí, com Newton Morton ${ }^{31}$ (Ferrari, 2004; Salzano, 2011). Nesse momento, a genética humana, que já havia se consolidado na década

$29 \quad$ No entanto, Cora conhecia Dreyfus, esteve em seu laboratório durante uma das estadas de Dobzhansky no Brasil, e foi uma das pesquisadoras que participou da fundação da Sociedade Brasileira de Genética, em 1955 (Ferrari, 2006, p. 328).

30 Como muitos geneticistas que iniciaram suas carreiras na primeira metade do século XX, Neel também teve sua introdução na genética a partir das drosófilas (Salzano, 2000).

31 Newton Morton, pesquisador estadunidense, foi um dos fundadores do campo da epidemiologia genética, tendo recebido, em 1962, o prêmio William Allan, concedido pela American Society of Human Genetics. 
anterior, teve um consistente processo de expansão, com muitos alunos dos pioneiros encontrando espaço em outras universidades e montando laboratórios de genética humana. Como exemplo temos Antonio Quelce Salgado, aluno de Freire-Maia, que passou a fazer parte da cadeira de biologia da Faculdade de Filosofia de Marília, em 1962, acompanhado de outro aluno de Freire-Maia e uma orientanda de Frota-Pessoa (Beiguelman, 1979, p. 1205). Outro aluno de Freire-Maia, Henrique Krieger, foi trabalhar no Departamento de Genética da Faculdade de Medicina de Ribeirão Preto, enquanto Manuel Ayres, aluno de Salzano, ajudou a criar um Instituto de Biologia na Universidade Federal do Pará (Beiguelman, 1979, p. 1206).

Dessa forma, nos anos 1960, novos laboratórios de genética humana eram criados e aqueles que existiam na década anterior passavam por uma expansão do número de pesquisas e do número de alunos. Esse processo não só foi intimamente associado ao desenvolvimento da genética de populações humanas em escala global, mas também, especificamente, às atividades da Fundação Rockefeller na América Latina (Souza \& Santos, 2014).

\subsubsection{O papel da Fundação Rockefeller na institucionalização da pesquisa em genética e os} contornos de uma divisão internacional do trabalho científico

Em minha dissertação de mestrado (Ferreira, 2013) discuti em maior detalhe a institucionalização da pesquisa em genética no Brasil e o papel desempenhado pela Fundação Rockefeller no processo de constituição de uma tradição científica na área. Retomo, aqui, alguns dos elementos principais dessa tradição, de modo a contextualizar a discussão sobre a divisão do trabalho, em algumas de suas manifestações e expressões, e sua contribuição para a formação e a consolidação do campo da genética de populações de drosófilas e da genética humana e médica no Brasil.

Como dito acima, em 1943, a Fundação Rockefeller, em um primeiro momento, financiou a vinda do biólogo russo Dobzhansky à USP, e a vinda de pesquisadores de outras instituições para estudar com ele (Formiga, 2007). Dessa maneira, em vez de dispersar recursos em diversas instituições, a Fundação estimulou primeiramente a concentração da pesquisa em genética da drosófila, em São Paulo. A escolha por financiar pesquisadores e grupos de pesquisa na cidade de São Paulo não foi fortuita, resultando, antes, de condições institucionais favoráveis, tais como a disseminação do regime de tempo integral para os pesquisadores, bem como a disponibilidade de oferecer contrapartidas locais aos recursos oferecidos, exigência da Fundação quando se tratava de gastar somas mais expressivas: 
É interessante assinalar também que, embora amparado por um discurso filantrópico, as ações empreendidas estavam marcadas pelo viés da eficiência. Desse modo, a filantropia pautava-se não por um suposto caráter desinteressado, caritativo, mas por uma lógica de resultados (...). Amparada nessa lógica de resultados, ou seja, respaldada por uma busca pragmática de produtividade e retorno dos investimentos, os recursos da Fundação Rockefeller continuaram sendo majoritariamente transferidos para São Paulo, cuja estrutura de poder - político e econômico - mostrava-se, naquelas circunstâncias, capaz de responder mais prontamente às exigências colocadas (Marinho, 2001, p. 154, grifos no original).

Tendo isso em vista, a concentração do financiamento em São Paulo era vista como forma de potencializar os investimentos realizados. A Fundação financiou, também, a ida de pesquisadores brasileiros para a Universidade de Columbia - onde Dobzhansky era professor. A ida dos pesquisadores brasileiros que vinham sendo treinados na genética para uma mesma instituição nos EUA acabou por provocar certa homogeneização da pesquisa feita na área de drosófilas, outra característica dessa tradição local em consolidação. A lógica de resultados marcou, ainda, a seleção de bolsistas brasileiros para a ida ao exterior, com a Fundação buscando identificar os talentos científicos já inseridos nas instituições acadêmicas, com mais chances de serem bem-sucedidos quando de seu retorno ao país. Segundo Brito da Cunha, um dos pesquisadores do grupo Dreyfus-Dobzhansky:

Miller visitava os nossos laboratórios, uma ou duas vezes por ano. Conversava com todos os pesquisadores dos laboratórios para ver como andavam as pesquisas. Consultava as pessoas dos laboratórios e entrevistava cada candidato. Só concedia bolsa a pesquisadores já aprovados em doutoramento e que comprovadamente teriam garantia de emprego ao regressar ao país. Posteriormente mantinha contato estreito com o bolsista no exterior, assim como com o seu professor responsável. Ao regressar ao Brasil, o bolsista recebia auxílio para aquisição de equipamento que iria precisar para o prosseguimento do seu trabalho. Dessa forma, levava para o exterior só pessoal muito bem selecionado e que já tinha adquirido aquilo que era possível, aqui no Brasil (Brito da Cunha, 1990, p. 11).

Nesse sentido, é possível afirmar que a Fundação buscava jovens pesquisadores já inseridos no espaço local de pesquisa e que possuíam treinamento específico em pesquisa. Eram necessárias, também, garantias institucionais de que esse pesquisador seria reintegrado quando do seu retorno, como forma de potencializar os resultados do investimento.

Também pode ser destacado como contribuição da Fundação o fomento a um estilo de pesquisa marcado pela coordenação e cooperação: foi tomada a decisão de limitar o número de projetos em torno de um projeto de pesquisa comum, o estudo da drosófila, e em muitos depoimentos dos membros desse grupo essa decisão é considerada acertada ${ }^{32}$. Destacando a

32 Tal decisão não se deu sem tensões, como no caso da saída de Newton Freire-Maia da linha oficial de pesquisa de genética de populações de drosófila, marcada por problemas com Dobzhansky, que não 
importância da pesquisa em equipes e de projetos comuns, em oposição à pulverização de trabalhos individuais, Pavan descreve, em 1989, a importância da Fundação, na figura de Miller e Dobzhansky, para a organização da pesquisa:

Desde o início, por decisão de Dreyfus, com o apoio de Dobzhansky, acertou-se que no laboratório iríamos desenvolver poucos projetos. Assim, todos que trabalhávamos com Dreyfus e Dobzhansky - entre 1943 e 1950 pesquisamos genética populacional de drosophilas e tínhamos apoio total de Harry M. Miller Júnior, que era responsável pelas atividades da Fundação Rockefeller no Brasil (Pavan, 1989, p. 454).

A difusão desse modelo concentrado de pesquisa para outras instituições se dá, também, com um controle rígido da pesquisa e dos pesquisadores. Esse processo configurou uma certa organização do trabalho, marcada pela concentração de recursos e por um conjunto limitado de temas de pesquisa. É possível afirmar que essa tradição foi, em grande medida, fomentada por um padrão específico de financiamento, que imprimiu características específicas ao trabalho dos pesquisadores, produzindo alterações significativas em suas práticas de pesquisa e nas características de sua formação (Ferreira, 2013).

Essas alterações disseram respeito, principalmente, ao modo de ensino da genética, progressivamente mais marcado pela pesquisa, no lugar das aulas baseadas em livros-texto, e à contratação de pesquisadores estrangeiros que enfatizavam o método experimental e o treinamento sistemático em laboratório, em detrimento de um certo autodidatismo que teria marcado o período anterior (Ferreira, 2013; Brieger, 2010) ${ }^{33}$. Outra mudança significativa no padrão de formação dos pioneiros da genética foi a ida para um conjunto muito restrito de universidades nos Estados Unidos, que reforçaram a organização institucional e as práticas de pesquisa dos cientistas.

Segundo Marinho (2001, p. 119), nesses processos existiria uma forma sutil de controle da Fundação, na medida em que ela determinava as áreas que seriam apoiadas e, por conseguinte, definia a agenda mais geral de temas e objetos de pesquisa. O controle não era direto, no sentido de determinar ao pesquisador o seu objeto específico de trabalho, mas de

aprovava sua pesquisa com espécies de moscas domésticas (Glick, 2003, pp. 158-159). Para mais detalhes sobre essas tensões ver Ferreira, 2013, pp. 49-51.

33 Nas palavras de Friedrich Brieger, geneticista alemão, que aceitou um convite para trabalhar na ESALQ, em 1936: “a Genética, praticamente, não existia no Brasil. Tinha professores que davam aulas sobre Genética, mas ninguém trabalhou em Genética. O sistema de dar aulas por livros realmente é um sistema de dar aulas de terceira mão. Antes de uma pesquisa entrar nos livros já se passaram quatro ou cinco anos; para o livro ser lido, usado e traduzido para o português outros cinco anos. Era tudo meio teórico e meio atrasado. (...). Nesta época, mais ou menos já no início, apareceu Mister Miller da Fundação Rockefeller que tinha começado a se interessar pela América Latina. O Miller me conhecia porque eu tinha sido bolsista da Rockefeller. Entrou em contato comigo dizendo não querer ajudar a Genética a ser ciência aplicada, porque isso o país deve fazer, mas ajudar a fundamentar, por exemplo a Genética e a Biologia em geral (Brieger, 2010, pp. 5-6). 
caráter indireto, na medida em que sinalizava as áreas para as quais havia disponibilidade de recursos. O papel indutor da Fundação Rockefeller fica ainda mais patente quando se trata da criação da genética humana no país. Embora alguns pesquisadores já demonstrassem algum interesse nessa área, sua criação efetiva só se deu a partir do momento em que a Fundação assinala a disponibilidade de recursos para o tema. Apesar de muitos pesquisadores identificarem a atuação da Fundação como dando grande espaço para a autonomia do pesquisador, vemos, com a criação da genética humana, a partir de 1950, como pesquisadores antes envolvidos com a genética de populações de drosófila - estimulada na década anterior também pela Rockefeller - mudam os temas de suas pesquisas (Ferreira, 2013). Claro que posteriormente, ao recontar essa mudança, os pesquisadores citados recorrem a interesses anteriores e vocações, não reconhecendo a influência, mesmo que indireta, que a Fundação exerceu nessa escolha (Frota-Pessoa, 1989; Freire-Maia, 1989). No entanto, descrevendo a criação da genética humana, Pavan é bastante explícito:

Ao redor de 1955, quase que por imposição da Fundação Rockefeller, que nos pedia, nos solicitava que iniciássemos um grupo trabalhando em Genética humana, então eu, na época, era presidente da Sociedade Brasileira de Genética, fiz uma Comissão de Genética Humana (...), e então abriu-se um novo campo no departamento, que era de Genética Humana (Pavan, 2010 , p. 84 , grifos meus).

A genética humana seguiu padrão semelhante à pesquisa com drosófila na década anterior. Inicialmente, a Fundação concedeu auxílio financeiro a poucos pesquisadores, para formá-los em uma universidade estadunidense, nesse caso, a Universidade de Michigan. Novamente optou-se pela concentração em poucos pesquisadores, em um conjunto delimitado de temas, e numa mesma instituição estrangeira. Na organização da comissão de genética humana da SBG pode-se, igualmente, ver uma adesão ativa dos pesquisadores a esse modelo concentrado e coordenado de pesquisas, tal qual pode ser verificado na fala de Frota-Pessoa:

A comissão de genética humana da SBG desempenhou de forma notável sua missão, porque examinava e aprovava projetos de pesquisa a serem financiados de forma ilimitada pela Fundação Rockefeller, realizando inúmeras atividades de intercâmbio científico. Seu êxito - eis a lição básica decorreu do fato de não pulverizar recursos, mas de concentrá-los (FrotaPessoa, 1989, p. 454).

Nesse sentido, mesmo em um momento de difusão da pesquisa em genética para outras instituições brasileiras, buscou-se reproduzir os elementos da tradição constituída. Como descrito brevemente, os principais elementos dessa tradição foram: 1) a concentração de recursos e pesquisadores em poucas instituições, notadamente em São Paulo; 2) a seleção 
de um projeto único, ou, em outros termos, a concentração em poucos temas de pesquisa; 3) a valorização do método experimental e do treinamento sistemático em laboratório; e 4) o desenvolvimento da pesquisa e da formação em torno da figura de um pesquisador estrangeiro, Dobzhanski, e o incentivo a experiências formativas em uma mesma instituição estrangeira, a Universidade de Columbia, o que provocou certa homogeneização da pesquisa feita na área de drosófilas.

O elemento mais importante dessa tradição, para esta pesquisa de doutorado, é a concentração em poucos temas de pesquisa. Tanto no caso da genética de populações de drosófilas quanto na genética humana, os pesquisadores buscaram encontrar temas que trariam certa facilidade para se inserir internacionalmente:

[Uma] possibilidade foi discutida entre o Dreyfus, Dobzhansky e eu ouvindo, era de que o melhor seria escolher poucos campos, o melhor seria escolher organismos tropicais, que não estavam sendo trabalhados nos países mais avançados (...). Acho que foi uma proposta não só válida, mas extremamente útil para nós, porque com esta filosofia de todos trabalharmos só em drosófila no departamento, a fama do departamento realmente se tornou internacional e chegamos a ter um dos melhores laboratórios de Genética de drosófila do mundo (Pavan, 2010, p. 29, grifos meus).

Agora, para nós a Drosophila foi extremamente importante porque conseguiu fazer com que o grupo de brasileiros trabalhasse num problema de fronteira com material nosso, sem muita competição internacional e produzindo trabalho de repercussão lá fora. A grande vantagem que eu vejo na Drosophila é que esse pequeno grupo de pessoas que começou teve uma grande influência na formação genética dos estudantes (...) e fez o progresso da genética (Pavan, 2010, p. 82, grifos meus).

No caso da pesquisa com drosófilas, tem-se a "opção" de trabalhar com organismos tropicais, espécies de drosófilas não existentes em climas temperados, que permitia produzir dados originais, não disponíveis nos centros de pesquisa de destaque na época, como a Universidade de Columbia. Na genética humana, tem-se como "opção" o estudo das populações isoladas e dos povos indígenas, além das questões ligadas à miscigenação, sendo que o Brasil foi descrito pelos pesquisadores da época como uma espécie de laboratório propício para investigar essas questões (Santos, Lindee \& Souza, 2014).

Nessas duas grandes linhas de pesquisa era possível produzir dados originais, sem precisar competir diretamente com centros de pesquisa internacionais. Foi possível aos pioneiros se inserir em pesquisas mais amplas e comparativas, a partir dos dados originais produzidos, publicar em revistas de alto impacto, construir carreiras bem-sucedidas, sem ter que rivalizar com os centros de pesquisa mais bem organizados e financiados. 
O problema é o seguinte (isso eu estou defendendo há muito tempo e foi o princípio básico, inclusive do departamento): é nós fugirmos da competição quando ela se mostra desnecessária, não interessa nós tentarmos competir com os americanos ou com os europeus ou com os japoneses se nós podemos, trabalhando com um organismo nosso em que eles não podem trabalhar, em que não haja competição, fazer uns trabalhos tão importantes e num nível superior [ao que] eles podem fazer no exterior (Pavan, 2010, p. 81, grifo meu).

Essa opção pela não competição direta, que fez com que os geneticistas brasileiros apostassem nas espécies tropicais de drosófilas e nas populações locais, reaparece quando passam a discutir o desenvolvimento da pesquisa em genética no país, a partir do diagnóstico das grandes transformações ocorridas nos maiores centros de pesquisa:

Um geneticista que está querendo fazer Genética de bactéria, que é feita de maneira tremendamente sofisticada em outros lugares, leva uma desvantagem terrível no Brasil. Tem que estar muito constantemente em contato, tem que, com muita habilidade, escolher tópicos ainda não explorados e agir muito rápido, pois os outros agem muito rápido também por que essa é uma área da Genética muito "quente". Se escolhe um organismo que não existe em outros lugares, que é peculiar no Brasil, isso lhe dá uma vantagem sobre os outros pesquisadores e pode descobrir coisas (Cordeiro, 2010, p. 66, grifo meu).

Vê-se aqui a tentativa de, novamente, encontrar organismos inexistentes nos grandes centros, de modo a manter uma inserção na comunidade científica internacional, não marcada pela competição direta. Subjacente, está a discussão de que há um progressivo aumento na velocidade das descobertas na área, dado pela mudança tecnológica. Assim, não se trata apenas de uma área "quente" - um espaço de alta competição -, mas um espaço que exige o acompanhamento dessas transformações técnicas de modo a poder participar dessa competição. A ideia da aceleração das descobertas e a metáfora da corrida marcam o desenvolvimento da biologia molecular e da genética de microrganismos, e a opção que os pioneiros citados defendem é a impossibilidade de participação direta nessa corrida:

Competir com este pessoal não é vantagem, porque já tem milhares de laboratórios, milhares não digo, mas já deve ter mil laboratórios atualmente trabalhando no assunto e esse pessoal está muito bem equipado (...). Então o que nós precisamos, a meu ver, é ter um grupo capaz de acompanhar se não totalmente pelo menos na área de coisas que nós temos a possibilidade de acompanhar o progresso e dizer: esse problema já pode ser aplicado no Brasil (Pavan, 2010, p. 72).

Pela escassez de material, não é possível afirmar se essa visão era compartilhada por todos os pioneiros, ou apenas por Pavan, Cordeiro e, em menor medida, por Salzano, a partir 
das longas entrevistas que eles concederam em 1977, para um projeto de história da ciência ${ }^{34}$. $\mathrm{O}$ fato de essa discussão ter sido feita pelos pioneiros indica, ainda, que provavelmente se tratava de um debate em andamento dentro do grupo dos geneticistas, debate esse que provavelmente abarcava posições contrárias à “opção pela não competição", posições essas que acabaram obscurecidas. No terceiro capítulo, essa discussão é trazida para o presente, a partir das entrevistas realizadas com pesquisadores em genética humana e médica.

Até agora me referi à "opção" de trabalhar com organismos tropicais e populações isoladas, mas uma forma mais precisa de descrever o fenômeno talvez seja o de extroversão, tal como propôs Hountondji $(1990 ; 2006)$ : a ideia de que acadêmicos do dito terceiro mundo, para atender a necessidades dos pesquisadores de países dos centros, devem produzir e apresentar dados originais, ou mesmo exóticos, movimento que o autor descreve em termos de um confinamento ao particular:

O discurso científico local é interessante apenas se olha para realidades locais (...). Limitados ao seu próprio horizonte, os pesquisadores do 'Terceiro Mundo' deixam para outros a tarefa de teorizar, interpretar os dados que eles reuniram e integrá-los em sistemas mais abrangentes. Pesquisadores do Sul negam a si mesmo o acesso ao universal. Objetivamente, eles operam como meros informantes a serviço da ciência mundial; informantes bem formados [learned informants], sem dúvida, mas informantes de toda forma - pessoas que não desenham as questões nem determinam o método, mas estão felizes em responder às questões que lhes são colocadas (Hountondji, 2006, p. 47).

Desse modo, subjacente a uma "opção", é possível ver a definição de agendas de pesquisa em uma relação de tensão e negociação com seus pares dos centros de pesquisa dos países centrais e com as agências de fomento internacionais. Esses breves trechos das falas dos pesquisadores mostram, também e justamente, que se trata de uma escolha estratégica ${ }^{35}$, evidenciada no recurso ao trabalho em temas específicos, locais, sobre os quais depositam expectativas quanto a sua inserção e visibilidade na comunidade internacional.

No entanto, a criação de um nicho específico de pesquisa, fortemente ligado à tradição local, a partir da pesquisa com espécies de drosófilas do mundo tropical e populações indígenas, que nenhum europeu ou norte-americano poderia estudar facilmente, teve outra

34 O projeto "História da ciência no Brasil", foi desenvolvido entre 1975 e 1978, coordenado por Simon Schwartzman, e financiado pela Financiadora de Estudos e Projetos (Finep). Resultou em 77 entrevistas com cientistas brasileiros de várias gerações, sobre sua vida profissional, a natureza da atividade científica, o ambiente científico e cultural no país e a importância e as dificuldades do trabalho científico no Brasil. As entrevistas podem ser consultadas em: http://cpdoc.fgv.br/acervo/historiaoral/entrevistas \#

35 A noção de "estratégia" não é aqui compreendida a partir dos pressupostos derivados da economia ou da administração, como unidade de análise individual, ator plenamente racional, otimização de decisões etc. Neste caso, a ênfase é dada à "estratégia" no sentido de respostas - coletivas -, ainda que não plenamente explícitas ou conscientes, às limitações de ordem institucional, organizacional e financeira. 
consequência: limitou o horizonte de pesquisa e atrasou a entrada dos pesquisadores brasileiros na genética de microrganismos, responsável pelos desenvolvimentos contemporâneos da pesquisa em genética e pelo advento da chamada biologia molecular. Assim, em certa medida, devido às especialidades dos pioneiros da genética brasileira e de seus discípulos, a genética de microrganismos não foi, após o seu sucesso no exterior, imediatamente introduzida no Brasil. Houve esforços isolados, entre 1940 e 1960, mas estes careceram de continuidade e vieram de grupos mais voltados à área de microbiologia e biofísica do que propriamente à genética (Pizzirani-Kleirer \& Azevedo, s. d.). Ao mesmo tempo, os geneticistas pioneiros identificaram a genética de microrganismos e a genética molecular como subáreas importantes no cenário internacional, tanto que no final dos anos 1950 foi criada a Comissão de Genética de Microrganismos e Genética Molecular, pela SBG. No entanto, em 1977, a comissão ainda era vista como pouco desenvolvida:

Na questão dos microrganismos, apesar de esforços como os da Sociedade Brasileira de Genética, que tentou incentivar esses estudos, o número de pessoas que se dedicam à pesquisa é pequeno. E em Genética molecular é menor ainda. Isso é inevitável devido à própria situação do país, em que existe a dependência completa de material importado para essas pesquisas.

\section{E essas pesquisas dependem de bastante material?}

É um nível de sofisticação enorme. O futuro dessa área no Brasil é ainda muito nebuloso, pelas restrições às importações (Salzano, 2010, pp. 29-30).

Uma das razões para o desenvolvimento menor desses temas é o aumento considerável dos custos desse tipo de pesquisa, aliado à dificuldade de importação do material necessário para a sua realização. Mas, talvez, o principal motivo para o não investimento, naquele momento, nesses desdobramentos, na genética, seja justamente os obstáculos para enquadrá-la na tradição desenvolvida anteriormente: a dificuldade de encontrar organismos locais, elementos "peculiares" ao Brasil, que permitissem realizar a pesquisa nos moldes da nãocompetição direta, desenhados pela tradição descrita acima.

Destaca-se que essa dificuldade tem algumas consequências pois a genética de microrganismos foi a que primeiro incorporou os desdobramentos da biologia molecular, base do que posteriormente foram os projetos genomas de sequenciamento. Demorar para entrar no que seria uma nova fase mundial da pesquisa em genética fez com que o Brasil perdesse o "bonde" da pesquisa em genética, só retomado a partir da década de 1990, com os financiamentos da Fapesp, na esteira dos projetos genomas (Dal Poz, 2002). 


\subsection{O campo brasileiro da genética humana e médica no Brasil}

Esta seção se dedica a apresentar o mapeamento do campo científico da genética humana e médica no Brasil, buscando elencar algumas de suas características institucionais e o conjunto dos diferentes agentes no interior do campo. O intuito é traçar um quadro contextual apresentando os contornos no interior dos quais se realiza a pesquisa em genética humana e médica. Lembro, aqui, que os procedimentos de seleção da amostra foram apresentados na introdução desta tese.

\subsubsection{Caracterização geral dos pesquisadores}

Do total de pesquisadores, 146 são homens e 235 são mulheres. Ou seja, 61,7\% dos pesquisadores selecionados são do sexo feminino e 38,3\% são do sexo masculino. Ao considerar apenas os indivíduos situados em faculdades de medicina essa proporção diminui um pouco (59\% de mulheres), mas mantém-se a predominância feminina da amostra.

É importante notar que quando se passa para alguns indicadores de prestígio, como, por exemplo, possuir Bolsa de Produtividade em Pesquisa do CNPq, é possível notar certa hierarquia de gênero. Dos 381 pesquisadores, 142 (37,3\%) possuem a bolsa de produtividade, dividindo-se em 76 pesquisadoras $(53,5 \%)$ e 66 pesquisadores (46,5\%). Tal proporção não segue a distribuição de gênero na amostra de pesquisadores, e há uma inversão do nível $1 \mathrm{C}$ em diante, em que a maior parte dos bolsistas passa a ser do sexo masculino, apesar de eles representarem $38,3 \%$ da amostra geral.

Tabela 3: Bolsistas de Produtividade CNPq divididos por sexo e nível (2015)

\begin{tabular}{cccccccc} 
Sexo & Nível 2 & Nível 1D & Nível 1C & Nível 1B & Nível 1A & Sênior & Total \\
\hline Masculino & 28 & 7 & 11 & 9 & 10 & 1 & 66 \\
\hline Feminino & 40 & 15 & 10 & 5 & 6 & 0 & 76 \\
\hline Total & 68 & 22 & 21 & 14 & 16 & 1 & 142 \\
\hline
\end{tabular}

Fonte: Plataforma Lattes.

Elaboração própria.

Uma das formas de financiamento do CNPq, a Bolsa de Produtividade em Pesquisa (doravante PQ) é atribuída a pesquisadores de todas as áreas científicas, baseado não só na qualidade de um projeto submetido, mas principalmente na "qualidade" do pesquisador. (Wainer \& Vieira, 2013, p. 62). É importante salientar que, sobretudo para docentes das universidades federais, essa frequentemente se apresenta como uma das principais fontes de financiamento, notadamente pela sua duração, de três a cinco anos. 
Inclusive, além do prazo de relativa extensão - que tende a ser maior do que as parcas oportunidades oferecidas estadualmente - o acesso ao nível mais baixo, o de bolsista 2 , em que o prazo máximo de execução da proposta é de 36 meses (CNPq, 2017), é o pressuposto para galgar os degraus de modo a ascender a bolsista 1 (categorias D, C e B), com prazo de execução de 48 meses, e, por fim, idealmente, alcançar a categoria 1A, que oferece prazo para a realização do projeto em até 60 meses. Desse modo, se o estado de São Paulo se apresenta como uma exceção em termos das oportunidades de financiamento, haja vista o volume de recursos que é disponibilizado pela Fapesp, no restante do Brasil a falta de garantias ou de volume (ou, em alguns casos, ambos) orçamentárias acaba tornando a bolsa PQ do CNPq ainda mais relevante para viabilizar projetos de maior fôlego, um aspecto fortalecido tendo em vista a sua flexibilidade em termos de uso da verba.

A seleção dos pesquisadores é realizada a partir dos comitês assessores para cada subárea do conhecimento, compostos por pesquisadores reconhecidos daquela subárea indicados por um conselho deliberativo do CNPq, que seleciona os membros por meio de consultas às entidades científicas e à comunidade científica, entre outros. Uma das funções dos comitês assessores é atribuir os níveis da bolsa de produtividade para os pesquisadores que submeteram propostas (CNPQ, 2017).

Criada em 1976, tal bolsa se institucionalizou progressivamente como um:

sistema hierarquizado de posições, tipificando um perfil de excelência do que pode ser considerado uma elite científica - a de especialistas e profissionais da pesquisa, a quem se reconhece a liderança na condução das atividades de C\&T no país e se contempla com recursos materiais e simbólicos (Guedes, Azevedo \& Ferreira, 2015, p. 369).

Nesse sentido, a bolsa de produtividade se destina a pesquisadores que desfrutam de alto reconhecimento entre seus pares e tem uma dinâmica própria de funcionamento que a distingue dos demais tipos de bolsa oferecidos. Além disso, às bolsas de produtividade podem ser vinculadas bolsas de formação de recursos humanos, destinadas a estudantes de graduação (iniciação científica) e de pós-graduação (mestrado, doutorado), e a recém-formados (bolsas de apoio técnico e de aperfeiçoamento) que atuam no projeto do pesquisador bolsista. Sua concessão implica, assim, também a possibilidade de mobilização de recursos indiretos.

A bolsa de produtividade tem algumas características importantes. A primeira delas é sua estratificação interna em três categorias: sênior; pesquisador 1, subdividida em níveis A, B, C, D; e pesquisador 2. Cada categoria corresponde a diferentes requisitos e critérios para solicitação, enquadramento, prazos de vigência e remuneração estipulada pela agência. $O$ 
número de bolsas de produtividade é fixo, por subárea, o que significa que, para que um pesquisador tenha acesso à bolsa $1 \mathrm{~A}$, outro deve perdê-la.

A tabela 3, acima, indica que quanto mais se sobe na hierarquia das bolsas, mais a proporção entre homens e mulheres tende a favorecer o gênero masculino. Nesse sentido, a distribuição por sexo segundo as categorias PQ repete o padrão encontrado por outras pesquisas: a concentração de mulheres na categoria 2 (Guedes, Azevedo \& Ferreira, 2015; Alves, Yanasse \& Soma, 2011). Destaca-se, no entanto, que as Ciências Biológicas são a terceira grande área em montante de Bolsas PQ e que o peso das bolsistas mulheres (46,1\%) é bastante superior em comparação a outras áreas, como as Ciências Exatas e da Terra e as Engenharias - primeira e segunda grande área em número de bolsistas de produtividade, em que o peso das mulheres na distribuição dessa bolsa é de, respectivamente, $23,3 \%$ e 18,8\% (Guedes, Azevedo \& Ferreira, 2015, pp. 383-387).

Outro indicador de prestígio científico possível é a ascensão ao nível de professor titular ou emérito. Dentre a amostra geral, apenas 42 indivíduos (11\%) se tornaram professores titulares - o topo da carreira universitária - e outros quatro receberam o título de professor emérito. Apesar de $61,7 \%$ da amostra serem mulheres, elas representam tão somente $43,5 \%$ dos professores titulares ou eméritos, evidenciando certa assimetria de gênero.

\subsubsection{Distribuição regional e institucional}

O Brasil realizou investimentos continuados e consideráveis na formação de recursos humanos em ciência e tecnologia nos últimos quarenta anos. Sustentado nos Planos Nacionais de Pós-Graduação (PNPG), o processo de expansão da pós-graduação resultou de planejamento e financiamento estatal, tendo como base institucional as universidades públicas. Como resultado, os cerca de 800 cursos de mestrado e doutorado da década de 1970 cresceram para quase 3.700 em 2008. Esses programas formaram, apenas em 2008, 33.360 mestres e 10.711 doutores, com um contingente de estudantes em torno de 140 mil (Ramos, 2014, p. 17). Essa expansão quantitativa ocorreu em todas as áreas do conhecimento, porém, de forma desigual no território nacional. Em 1996, o estado de São Paulo oferecia 36,4\% dos programas de mestrado e 55\% dos de doutorado. Doze anos depois, a concentração havia diminuído e São Paulo oferecia 36\% dos doutorados. Ainda assim, a liderança desse estado é notável, principalmente quando se leva em consideração a presença de programas com notas mais altas: $42,7 \%$ dos programas de mestrado e doutorado avaliados com conceitos 5,6 ou 7 pela CAPES, em 2008, estavam localizados em São Paulo (Ramos, 2014, p. 18). 
Conforme pode ser verificado na tabela a seguir, mais de metade da amostra de pesquisadores em genética humana e médica trabalha em instituições no Sudeste do país, mostrando forte concentração geográfica. Tal concentração não destoa dos dados gerais da ciência brasileira, conforme pode ser verificado na coluna à direita da tabela, que indica a distribuição percentual do total de docentes brasileiros por região geográfica, de acordo com dados coletados pela Capes em 2013.

Tabela 4: Distribuição geográfica de pesquisadores em genética humana e médica (2015) e do total de docentes brasileiros (2013)

\begin{tabular}{cccc} 
Distribuição & $\begin{array}{c}\text { Pesquisadores } \\
\text { Genética } \\
\text { Gumana }\end{array}$ & $\%$ & $\begin{array}{c}\text { \% docentes } \\
\text { brasileiros }\end{array}$ \\
Centro Oeste & 21 & 5,5 & 4,5 \\
Norte & 29 & 7,6 & 7,7 \\
Nordeste & 62 & 16,3 & 18,5 \\
Sul & 73 & 19,2 & 19 \\
Sudeste & 196 & 51,4 & 50,3 \\
Total & 381 & 100 & 100 \\
\hline
\end{tabular}

Fonte: Plataforma Lattes, Portal da Transparência e Geocapes (2014).

Elaboração própria.

Nesse sentido, é possível dizer que a pesquisa em genética humana reproduz a concentração identificada na própria organização da pesquisa nacional. É interessante notar que, quando se olha para a distribuição não de pesquisadores, mas dos grupos cadastrados no Diretório de Grupos de Pesquisa - Plataforma Lattes - $\mathrm{CNPq}^{36}$, essa desigualdade geográfica se ameniza um pouco, com proporcionalmente menos grupos do Sudeste na amostra, como pode ser visto na tabela abaixo.

Tabela 5: Distribuição geográfica dos grupos de pesquisa em genética humana e médica cadastrados no CNPq - 2016

\begin{tabular}{|ccc|}
\hline Região & Grupos CNPq & $\%$ \\
\hline Centro-Oeste & 6 & 8 \\
\hline Norte & 8 & 10,6 \\
\hline Nordeste & 15 & 20 \\
\hline Sul & 14 & 18,7 \\
\hline Sudeste & 32 & 42,7 \\
\hline Total & 75 & 100 \\
\hline
\end{tabular}

\footnotetext{
36 O Diretório dos Grupos de Pesquisa do CNPq reúne informações sobre os grupos de pesquisa em atividade no país abrangendo pesquisadores, estudantes, técnicos, linhas de pesquisa, e produção científica, tecnológica e artística geradas pelos grupos. Apesar de caracterizar-se como uma base de informações de preenchimento opcional, o universo abrangido pela mesma vem aumentando ao longo do tempo, podendo-se supor relativa representatividade do espaço científico nacional (Rapini, 2007, p. 103).
} 
Fonte: Diretório de Grupos de Pesquisa - Plataforma Lattes - CNPq. Elaboração própria.

É possível levantar como hipótese o fato de muitos dos grupos do Sudeste estarem envolvidos com outros grupos e redes, tais como os Centros de Pesquisa, Inovação e Difusão (Cepids-Fapesp) e os Institutos Nacionais de Ciência e Tecnologia (INCT-CNPq), que já conferem destaque simbólico suficientemente significativo para não valerem o esforço adicional de organizar grupos e se tornar "líderes de pesquisa".

Do ponto de vista da concentração institucional, alguns aspectos se destacam quando se observa as diferentes regiões. Entre as instituições localizadas no Nordeste, o destaque está com a UFBA, a UFPE e a UFAL, respectivamente com 11, 10 e 07 pesquisadores. Os demais 34 pesquisadores estão distribuídos em 17 outras instituições, sendo que cinco delas contam com apenas um pesquisador ligado à genética humana. Padrão semelhante pode ser encontrado na região Sul, em que os 73 pesquisadores dividem-se em 16 instituições. No entanto, 54 desses pesquisadores encontram-se em quatro instituições: 25 pesquisadores na UFRGS, 13 na UFPR, 9 na UFCSPA e 07 na UFSC.

$\mathrm{Na}$ região Norte encontra-se a maior concentração de pesquisadores em uma mesma instituição: 20 dos 29 pesquisadores pertencem ao corpo docente da UFPA. No Centro-Oeste, a região geográfica com o menor número de pesquisadores na área (o que se explica em parte pela concentração de pesquisadores em outras áreas, como genética vegetal e biotecnologia), 19 deles se dividem entre três das principais instituições da região: UnB, UFG e UFMT.

A região Sudeste, responsável por mais de metade dos pesquisadores representados na amostra, também tem composição interna bastante diversificada. Do total de 196 pesquisadores, 62,8\% encontram-se no estado de São Paulo. Olhando especificamente para esse estado, verifica-se, também, um alto contingente de pesquisadores localizados na USP, totalizando 49,6\% dos pesquisadores de São Paulo.

Tabela 6: Distribuição dos pesquisadores na região Sudeste (2015)

\begin{tabular}{|ccc|}
\hline Estado & $\mathbf{n}^{\mathbf{0}}$. pesquisadores & $\mathbf{\%}$ \\
\hline ES & 3 & 1,5 \\
\hline MG & 28 & 14,3 \\
\hline RJ & 42 & 21,4 \\
\hline SP & 123 & 62,8 \\
\hline Total & 196 & 100 \\
\hline
\end{tabular}

Fonte: Diretório de Grupos de Pesquisa - Plataforma Lattes - CNPq. Elaboração própria. 
Deslocando o olhar para a distribuição entre as diferentes instituições, chama a atenção que os pesquisadores estão divididos entre 74 instituições de ensino e pesquisa, sendo que 49 delas não contam com mais de três pesquisadores ${ }^{37}$. Como já destacado, a USP é a instituição com maior número de pesquisadores, seguida pela UFRGS, UFPA e Unicamp. Na tabela abaixo destacam-se as instituições que têm dez ou mais pesquisadores em genética humana.

Tabela 7: Instituições com mais pesquisadores em genética humana (2015)

\begin{tabular}{|cccc|}
\hline Instituição & Estado & Região & Pesquisadores \\
USP & SP & Sudeste & 61 \\
\hline UFRGS & RS & Sul & 25 \\
UFPA & PA & Norte & 20 \\
\hline UNICAMP & SP & Sudeste & 16 \\
\hline UFMG & MG & Sudeste & 16 \\
\hline UFPR & PR & Sul & 13 \\
\hline UNIFESP & SP & Sudeste & 12 \\
\hline UNESP & SP & Sudeste & 12 \\
\hline UFBA & BA & Nordeste & 11 \\
\hline UFPE & PE & Nordeste & 10 \\
\hline
\end{tabular}

Fonte: Plataforma Lattes e Portal da Transparência.

Elaboração própria.

Do ponto de vista das instituições a que estão ligados os pesquisadores em genética humana é possível dizer que, embora exista uma relativa dispersão, a concentração em algumas poucas instituições é o padrão dominante. Destacam-se, no entanto, alguns polos regionais no Norte e Nordeste, por exemplo a UFPA, terceira instituição em número de pesquisadores, e a UFBA. Nesse sentido, é possível notar que, embora a distribuição geográfica geral dos pesquisadores mantenha correlação com a distribuição total dos docentes brasileiros, ao olhar de forma mais desagregada para as instituições, identifica-se alguns grupos de pesquisadores em instituições menos centrais, tomando o ponto de vista do campo científico brasileiro.

A distribuição regional das Bolsas PQ - tomada como um indicador dos pesquisadores que compõem a elite do sistema de pesquisa - demonstra um grau de concentração ainda maior do que aquele encontrado nos dados anteriores.

37 No anexo 2 encontra-se a tabela com todas as instituições de ensino e pesquisa da amostra, bem como o número de pesquisadores associados a cada uma delas. 
Tabela 8: Distribuição de bolsista de produtividade CNPq por região geográfica (2015)

\begin{tabular}{|ccc} 
Região & $\begin{array}{c}\text { Bolsa } \\
\text { Produtividade }\end{array}$ & $\%$ \\
\hline Centro-Oeste & 5 & 3,5 \\
\hline Norte & 6 & 4,2 \\
\hline Nordeste & 10 & 7,1 \\
\hline Sul & 25 & 17,6 \\
\hline Sudeste & 96 & 67,6 \\
\hline Total & 142 & 100 \\
\hline
\end{tabular}

Fonte: Plataforma Lattes.

Elaboração própria.

Ao mesmo tempo, ao se desagregar esses dados por instituição, verifica-se, mais uma vez, a existência de ao menos um polo regional, para além do eixo Sudeste-Sul, a UFPA, contando com seis pesquisadores bolsistas de produtividade.

Tabela 9: Bolsista PQ por instituição (cinco bolsas ou mais) - 2015

\begin{tabular}{|cc|}
\hline Instituição & Bolsa Produtividade \\
USP & 42 \\
UFRGS & 13 \\
UFMG & 9 \\
UFRJ & 7 \\
\hline UNICAMP & 7 \\
UFPA & 6 \\
\hline Total & $\mathbf{8 4}$ \\
\hline Outras instituições & 58 \\
\hline Total Geral & 142 \\
\hline
\end{tabular}

Fonte: Plataforma Lattes.

Elaboração própria.

Foi possível verificar, a partir dos dados apresentados neste item, uma forte concentração geográfica dos pesquisadores em genética humana, que ocorre simultaneamente a uma significativa dispersão institucional, com pesquisadores isolados inseridos em diversas instituições. Além disso, foi possível verificar que, mais do que uma concentração regional, há a constituição de grupos de pesquisa em um número relativamente pequeno de instituições, localizadas notadamente nas regiões Sudeste e Sul, mas com alguns grupos de destaque nas regiões Norte e Nordeste, como é o caso da UFPA, terceira instituição em número de pesquisadores. 


\subsubsection{Tipo de instituição}

No Brasil, a produção de conhecimento em genética humana e médica está solidamente ancorada nos departamentos e laboratórios ligados às universidades públicas, em nível estadual ou federal. Na tabela abaixo, os pesquisadores da amostra estão distribuídos a partir do tipo de instituição ao qual estão vinculados.

Tabela 10: Tipo de instituição em que se localizam os pesquisadores (2015)

\begin{tabular}{|cc|}
\hline Tipo Instituição & Pesquisadores \\
\hline $\begin{array}{c}\text { Instituição Particular de } \\
\text { Ensino }\end{array}$ & 3 \\
$\begin{array}{c}\text { Faculdade estadual ou } \\
\text { municipal }\end{array}$ & 7 \\
Hospital Particular & 11 \\
Instituto de Pesquisa & 18 \\
Público & 122 \\
\hline $\begin{array}{c}\text { Universidade Estadual } \\
\text { Universidade Federal }\end{array}$ & 220 \\
Total & 381 \\
\hline
\end{tabular}

Fonte: Plataforma Lattes.

Elaboração própria.

Mais recentemente há o desenvolvimento de pesquisa em genética humana e médica em hospitais não ligados à universidade, como é o caso do Hospital A. C. Camargo e do Hospital Albert Einstein, bem como em institutos de pesquisa, como o Instituto Ludwig de Pesquisas sobre o Câncer. Ainda que sua representação seja baixa na amostra geral, em termos quantitativos essas instituições vêm se consolidando como lócus da pesquisa em genética médica, sendo financiadas e, portanto, também disputando a verba das agências públicas de fomento. Os pesquisadores do Hospital A. C. Camargo, por exemplo, conseguiram aprovar um Instituto Nacional de Ciência e Tecnologia em Oncogenômica (vigente de 2008 a 2013).

De toda forma, trata-se de pesquisa realizada nos moldes do que Terry Shinn (2008) chamou de regime disciplinar de produção e de distribuição do conhecimento científico. $\mathrm{O}$ conceito de regimes de produção e de distribuição do conhecimento científico parte do reconhecimento de que a ciência constitui-se como esfera relativamente autônoma - social e cognitivamente -, levando em conta não só o seu enraizamento histórico, como a diversidade das suas práticas e culturas de pesquisa. Nas palavras do autor:

A gênese de cada regime [de produção e de distribuição do conhecimento científico] corresponde ao ambiente cognitivo, político e econômico de uma época histórica, às dimensões culturais de um dado tempo. Cada regime possui também sua divisão específica de trabalho, sistema organizacional, 
regras e hierarquia internas, universo de emprego, formas de produzir resultados, clientela e seu sistema particular de circulação entre produção e mercado. É esse conjunto complexo de fatores que estabelece as diferenças entre os regimes e sobre o qual suas respectivas fronteiras são baseadas (Shinn, 2008, pp. 13-14).

Shinn (2008) distingue quatro regimes: o disciplinar, o utilitário, o transitório e o tecnológico [Research-Technology]. A pesquisa em genética humana é organizada a partir de características do regime disciplinar, definido por Shinn da seguinte forma:

\begin{abstract}
O regime disciplinar de produção e difusão da ciência está assim baseado em departamentos disciplinares de universidades, cujo objetivo é: (1) reproduzir o conhecimento disciplinar-padrão para os estudantes e (2) conduzir pesquisa original no interior da disciplina. O regime disciplinar é fortemente definido por sua orientação autorreferente. Com relação aos tópicos de pesquisa, eles são retirados do interior da disciplina e relacionam-se tanto com a história e a inércia disciplinares, como com a direção para a qual o futuro da disciplina aponta, segundo a percepção dos praticantes disciplinares. A disciplina também estabelece seus critérios internos para a avaliação de seus resultados de pesquisa. (...). O regime disciplinar constitui seu próprio mercado. Os praticantes são os consumidores de suas próprias produções. O resultado da pesquisa está dirigido aos pares disciplinares, que avaliam, portanto, a qualidade do resultado e consomem os produtos cognitivos gerados por outros colegas disciplinares (Shinn, 2008, p. 17).
\end{abstract}

No caso brasileiro, Maria Carlotto (2013) propôs falar em regime disciplinar/estatal pois "embora a estrutura disciplinar possa existir fora do sistema estatal de produção do conhecimento, ou seja, sem o financiamento do Estado, não é o que acontece no Brasil, nem em outros países, sobretudo os europeus" (Carlotto, 2013, p. 44). O regime disciplinar está sólida e historicamente baseado na universidade. O processo se inicia por volta do início do século XIX, quando os Estados nacionais orientaram a produção e a reprodução do conhecimento para uma nova forma de organização, ao mesmo tempo unida ao Estado e buscando independência da intervenção política e estatal, e lutando sistematicamente para evitar a vinculação às demandas práticas de curto prazo economicamente orientadas (Shinn, 2008, p. 17). No Brasil esse movimento é mais recente.

O processo de institucionalização científica no Brasil, levando em conta apenas as ciências naturais, apresentou três fases de implantação, segundo Maria Amélia M. Dantes (1988, pp. 265-275). No primeiro momento, de meados do século XVIII até meados do século XIX, foram feitas as primeiras viagens e expedições e criadas as primeiras associações científicas, como a Academia Científica e a Sociedade Literária. Com o estabelecimento da Corte portuguesa na colônia, em 1808, há o desenvolvimento de medidas mais concretas para 
a institucionalização da atividade científica no Brasil, com a fundação de algumas escolas profissionais, bibliotecas e museus.

O segundo momento seria a introdução da ciência experimental no final do século XIX, que corresponde ao auge da produção cafeeira e à transferência do centro econômico e político do Brasil para a região Sudeste. Apesar de a cultura científica brasileira ser, nesse período, menos desenvolvida que a cultura literária, a autora destaca a criação da Sociedade Brasileira de Ciências (atual Academia Brasileira de Ciências), em 1916, e as reformas nas escolas profissionais de engenharia e medicina, que incluíram o ensino prático e contrataram professores estrangeiros, apesar de não chegarem a inserir a pesquisa em seus currículos. Foi somente com a atuação dos primeiros institutos de pesquisa na área de microbiologia, criados a partir de 1889, já no período republicano, que se iniciou uma tradição em medicina experimental no país, com o Instituto Bacteriológico de São Paulo, dirigido por Adolfo Lutz, e o Instituto Manguinhos, dirigido por Oswaldo $\mathrm{Cruz}^{38}$ (Dantes, 1988, pp. 268-271).

O terceiro momento da implantação da ciência no Brasil se daria com a criação tardia - das universidades brasileiras e o desenvolvimento das ciências básicas, a partir de 1930. Se, nos períodos anteriores, houve a criação de instituições de ensino superior visando essencialmente a formação de profissionais mais propriamente voltados à organização do Estado (oficiais militares, engenheiros, médicos e advogados), neste período foram criadas as universidades, baseadas no modelo universitário francês e alemão (Paula, 2002). Foram fundadas neste período as universidades do Distrito Federal (Rio de Janeiro) e de São Paulo, as primeiras a serem implantadas de forma duradoura no país. Essas duas universidades, apesar de terem objetivos políticos distintos, tinham algumas características comuns: a contratação de professores estrangeiros, o objetivo de desenvolver pesquisa básica desinteressada, além da formação de profissionais liberais, e a tentativa de aliar o ensino à pesquisa, tornando-se centros formadores de pesquisadores (Dantes, 1988, pp. 271-273). É nesse momento que se pode falar em desenvolvimento do regime disciplinar/estatal, ainda que sua construção não tenha sido exatamente linear.

38 Dantes destaca dois fatores para o sucesso dessas instituições: a) o apoio do governo, interessado no controle das epidemias que assolavam o país e comprometiam sua imagem no exterior, criando barreiras à política de atração de mão de obra estrangeira; b) o interesse de uma parcela da classe médica brasileira, atraída pelas novas áreas da medicina preventiva, mais especificamente na linha dos trabalhos desenvolvidos por Pasteur (Dantes, 1988, p. 270). Ver também: Cukierman, 2007. 


\subsubsection{Departamentos universitários}

A universidade brasileira contemporânea está estruturada em departamentos. A quantidade e especialização deles varia, principalmente, de acordo com a antiguidade da instituição e os recursos disponíveis. Os pesquisadores da genética humana não estão todos localizados em departamentos de genética, ainda que esses sejam maioria.

Tabela 11: Inserção departamental (2015)

\begin{tabular}{|cc|}
\hline Departamentos & Pesquisadores \\
\hline Genética & 80 \\
\hline Medicina & 71 \\
\hline Biologia & 64 \\
\hline Genética, Faculdade & \\
de Medicina & 34 \\
\hline Biomedicina & 25 \\
\hline Biologia Molecular & 11 \\
\hline Farmácia & 10 \\
\hline Bioquímica & 8 \\
\hline Patologia & 5 \\
\hline Biofísica & 4 \\
\hline Fisiologia & 4 \\
\hline Biologia Celular & 3 \\
\hline Ecologia & 3 \\
\hline Centro de Pesquisal & 32 \\
\hline Hospital Particular & 27 \\
\hline Outros/ Não informado & 381 \\
\hline Total & \\
\hline
\end{tabular}

Fonte: Plataforma Lattes. Elaboração própria.

Para facilitar a compreensão, alguns departamentos foram agrupados. A categoria "Outros" agrupa os departamentos com apenas um pesquisador na amostra, como Botânica, Odontologia e Estatística. Os departamentos de Química e Bioquímica foram agrupados em "Bioquímica". Os departamentos de Biomedicina, Ciências da Saúde, Ciências da Vida, e Ciências Básicas da Saúde foram agrupados em conjunto com o nome de "Biomedicina". "Medicina" agrupa desde departamentos com esse nome a outras especialidades médicas, como a pediatria ${ }^{39}$, a oncologia e a clínica médica.

Na rubrica "Genética", estão inseridos os departamentos de Genética e Biologia Evolutiva, Genética e Biologia Molecular, Genética e Bioquímica, entre outros. Optou-se por manter separados os departamentos de genética localizados não nas faculdades ou institutos

39 A pediatria é a especialidade médica que mais se destaca, devido ao fato de a maior parte das doenças genéticas começarem a se desenvolver ainda na infância. 
de ciências biológicas, mas nas faculdades de medicina. $\mathrm{O}$ fato de a genética humana estar focada no estudo das doenças genéticas explica, em parte, a força que as faculdades de medicina têm nesse campo de pesquisa. A relação entre a genética e a medicina ocorre desde a constituição do campo de pesquisa, quando foram criados, em paralelo, laboratórios de genética humana na Faculdade de Medicina e no Departamento de Biologia Geral, na USP (Ferreira, 2013, pp. 36-37) ${ }^{40}$. Essa relação será trabalhada ao final deste capítulo.

Além disso, a disciplina de genética humana faz parte do currículo da maior parte das faculdades de medicina, embora seja possível afirmar que ela não ocupe uma posição de destaque dentre as diversas especialidades. A primeira residência em Genética Médica no Brasil foi criada em 1977, no Hospital das Clínicas de Ribeirão Preto da USP (Emerick; Montenegro \& Degrave, 2007), e seu reconhecimento como especialidade médica pelo Conselho Federal de Medicina ocorreu apenas seis anos depois, em $1983^{41}$. Além de recente, até os dias atuais continua sendo a especialidade médica com menos integrantes, havendo tão somente 305 médicos geneticistas, com título de especialista, em 2018 (Sheffer et al., 2018, p. 109). A segunda e a terceira menores especialidades, Radioterapia e Cirurgia da Mão têm, respectivamente, 734 e 791 titulados, enquanto a especialidade com maior número de titulados é a Clínica Médica, com 42.728 especialistas (Sheffer et al., 2018, p. 110).

De toda forma, identificar as relações e tensões entre as duas grandes áreas - ciências biológicas e medicina - faz parte da compreensão do campo científico em genética humana e médica e será abordado mais adiante neste capítulo. Lenoir (2003), discutindo aspectos fundamentais para a análise da criação, desenvolvimento e transformação de disciplinas científicas, enfatiza a necessidade de olhar para a relação com as disciplinas vizinhas na constituição de uma nova. Nesse sentido pode-se afirmar que para o desenvolvimento de uma disciplina, como o da genética humana e médica, é necessário contar com as contribuições de outras disciplinas e especialidades.

Destaca-se, a partir da tabela acima, que, se contabilizados os departamentos de genética nas ciências biológicas e na medicina, a porcentagem de pesquisadores com essa inserção institucional é de 34,9\% ${ }^{42}$. Em segundo lugar, tem-se os departamentos agrupados

\footnotetext{
$\overline{40}$ Os pioneiros da genética humana realizaram estágio doutoral ou pós-doutoral com James V. Neel, em um departamento de genética humana inserido na Faculdade de Medicina da Universidade de Michigan (Ferreira, 2013, p. 143). Nesse sentido, tanto no Brasil quanto nos grandes centros, essa justaposição existe de longa data (Lindee, 2005).

41 Criada pela resolução $\mathrm{n}^{\circ} 1128 / 1983$ disponível em: http://www.portalmedico.org.br/resolucoes/CFM/1983/1128_1983.htm. Acesso em 30 de maio de 2016.

42 Para essa conta foram excluídos os pesquisadores que não são vinculados às universidades e aqueles em que a informação sobre o vínculo departamental não estava disponível. São 329 os pesquisadores ligados a departamentos em universidades, excluindo 20, cuja informação é desconhecida, e 32, que estão ligados a
} 
em "Medicina" (21,7\%) e os departamentos de Biologia (19,6\%). Esse segundo caso revela que em algumas instituições de ensino superior brasileiras não há especialização departamental na área de ciências biológicas, com um mesmo departamento agrupando pesquisadores em genética, botânica, zoologia, entre outras subáreas.

A partir desses dados é possível dizer que, apesar de a pesquisa em genética humana e médica ser fortemente disciplinar, localizada preponderantemente nos departamentos de genética, nas principais instituições de pesquisa no país, encontram-se alguns pontos de convergência com outras disciplinas científicas, como a biologia molecular e a bioquímica (com 5,8\% dos pesquisadores) e a biomedicina, com 7,6\%. Atualmente, a relação com a biologia molecular e a bioquímica é fundamental para a pesquisa em genética humana, pois houve uma progressiva modificação não apenas das questões de pesquisa, como das técnicas, instrumentos e demais práticas de pesquisa, principalmente a partir da crescente incorporação da biologia molecular no estudo do humano e a passagem da genética clássica para a "nova genética"43 ou genômica (Correa, 2002; Wilkie, 1994).

De maneira bastante esquemática é possível definir a genética clássica e a genômica da seguinte maneira: 1) a genética mendeliana ou clássica é aquela que estuda a correlação entre um único gene e um traço (cor dos olhos, por exemplo) ou uma doença (monogênica); 2) a genômica, por sua vez, é o estudo direto de genes, de suas funções e interações simultâneas (Correa, 2002). Além das doenças monogenéticas, ela tem como objeto traços e doenças poligênicas e multifatoriais, que envolvem a interação entre diferentes genes e destes com fatores ambientais não-genéticos. O marco mais emblemático dessa "nova genética" é, sem dúvida, o Projeto Genoma Humano (Wilkie, 1994).

As pesquisas em sociologia da ciência sobre o PGH têm explorado o desenvolvimento de técnicas laboratoriais cruciais para o PGH, como o desenvolvimento do PCR (Rabinow, 1996; Jordan \& Linch, 1998), o desenvolvimento de técnicas de mapeamento, informação, computação e automação dos processos (Hilgartner, 2004; Hine, 1995; Mackenzie, 2003), as modificações na prática clínica (Hogle, 2008; Lock, 2008), além das implicações éticas de tal empreendimento (Caplan, 2000; Dreger, 2000). De forma resumida, é possível afirmar que o PGH foi um megaprojeto ${ }^{44}$ que associou desenvolvimentos da pesquisa em genética, biologia hospitais e centros de pesquisa, como o Instituto Nacional do Câncer, no Rio de Janeiro, e o Hospital Albert Einstein, em São Paulo.

43 A expressão "nova genética" foi cunhada em 1980 por David Comings, editor da revista American Journal of Human Genetics, ao comentar as novas técnicas para análise do DNA (Wilkie, 1994).

44 Usando o conceito de big science, tal como formulado por De Solla Price (1963), muitos pesquisadores qualificaram o PGH como o primeiro empreendimento desse tipo desenvolvido para as ciências biológicas (Leite, 2006; Beatty, 2000), estando o modelo até então restrito à química e, principalmente, à física, que inaugurou o empreendimento big science com o Projeto Manhattan de construção da bomba nuclear. 
molecular, biotecnologia, biofísica, teoria da informação e computação (Sloan, 2000), e que marcou a conversão da pesquisa biológica a um modelo predominantemente molecular (Hedgecoe \& Martin, 2008).

A biologia molecular, que promoveu o desenvolvimento de projetos genoma, desenvolveu-se ao longo do século XX e apresenta três marcos relevantes: o descobrimento da estrutura de DNA (1953), das técnicas de RNA recombinante (1970) e de novas técnicas e equipamentos que automatizaram o processo de sequenciamento do genoma de organismos vivos (1995). Durante muito tempo a biologia molecular se concentrou no estudo de micróbios, vírus, bactérias e outros organismos mais $\operatorname{simples}^{45}$ e, a partir deles, foi desenvolvida uma série de técnicas moleculares que puderam ser, posteriormente, utilizadas na genética humana (Rheinberger, 2000):

Gradualmente, quase sem o perceber, os pesquisadores começaram a reunir um poderoso instrumental que lhes permitia "editar" o texto genético escrito na hélice dupla. Descobriram tesouras moleculares com que podiam cortar um fragmento de texto e uma fita adesiva biológica para colar os pedaços de texto editado. Mais importante que tudo, começou-se a perceber que o conjunto microbiano de ferramentas para a edição do DNA era capaz de localizar textos específicos dentro do DNA (Wilkie, 1994, p. 71).

A noção de uma ciência em nível molecular varia consideravelmente conforme os agentes que a empregam, sendo considerada por alguns uma disciplina científica com status cognitivo autônomo (Abir-Am, 1982; Kay, 1993) e, por outros, um grande e potente conjunto de técnicas para a compreensão de fenômenos complexos em toda sorte de organismos (Sloan, 2000). Seja como for, essa forma de prática científica passou a dominar institucional e conceitualmente os departamentos de biologia em grande parte do mundo ocidental a partir dos anos 1960 e passou a ser estendida, a partir da década de 1970, para a genética humana e médica com base nas discussões e na elaboração do PGH (Sloan, 2000; Kohler, 1976).

Internacionalmente o campo da genômica ganha destaque a partir dos anos 1970, sobretudo pelos avanços dos projetos de sequenciamento genético de uma diversidade de organismos. Essa nova forma de fazer pesquisa reconfigurou os rumos do espaço científico em relação às áreas prioritárias para a formulação de programas e para o destino de recursos financeiros para a pesquisa (Silva \& Costa, 2012). No Brasil, é a partir da década de 1990 que há um aumento considerável no financiamento da pesquisa em genética, primeiro em São Paulo, na esteira dos desdobramentos da biologia molecular e da genômica nos grandes centros de pesquisa internacionais.

45 A explicação para isso é que o DNA das bactérias está organizado em um único cromossomo, em contraste com as células muito mais complexas dos fungos, plantas e animais (Gaudillière, 1993). 
A Fapesp tomou como um de seus objetivos institucionais a criação desse novo campo de pesquisa no Brasil, para permitir que a produção científica nacional participasse da comunidade genômica internacional (Dal Poz, 2002; Negraes \& Egler, 2002). Para tanto, foi formulado o primeiro Projeto Genoma Brasileiro ${ }^{46}$, cujo objetivo era dar conta de três metas: (i) formar um grande número de pesquisadores nesses temas emergentes, (ii) participar internacionalmente como protagonista das pesquisas genômicas, e (iii) estimular a criação e incorporação da biotecnologia no setor produtivo (Hamburger, 2004; Henriques, 2010).

A partir desse primeiro projeto, constituiu-se uma orientação de política de C\&T no Estado de São Paulo (e depois no resto do país), preocupada com o desenvolvimento de uma infraestrutura científica e tecnológica que estimulasse a pesquisa de fronteira em genômica, principalmente aquelas aplicadas à medicina, tal como pode ser evidenciado pela criação do Projeto Genoma do Câncer (Silva \& Costa, 2012), do qual muitos dos pesquisadores da amostra, em São Paulo, fizeram parte. O Projeto Genoma do Câncer, idealizado em 1999, foi resultado da cooperação entre a Fapesp e o Instituto Ludwig de Pesquisas sobre o Câncer (um centro de pesquisa internacional com laboratórios em 13 países, dentre eles, o Brasil). O objetivo principal do projeto era produzir sequências de genes extraídas de tumores humanos e, com isso, gerar uma base de dados de livre acesso internacional, possível de ser consultada e complementada em outros centros de pesquisa estrangeiros (Kimura \& Baía, 2002).

Esse processo institucional de incentivo à pesquisa em genômica e de qualificação de pesquisadores e instituições nas novas modalidades de pesquisa - em termos de agenda e metodologias - explica, em parte, o espraiamento da pesquisa em genética humana e médica para outros departamentos, quando a modalidade de pesquisa em genética de populações passou a ser minoritária, diante da nova agenda de pesquisa que se delineou ${ }^{47}$.

\subsubsection{Formação dos pesquisadores}

Parte fundamental do retrato sobre o campo da genética do Brasil passa pela compreensão do processo de formação dos pesquisadores, considerado por muitos sociólogos como central no estudo sociológico da ciência (Bourdieu, 2001; Ben-David, 1974), pois é ao longo desse processo que os cientistas incorporam a tradição científica, um certo ethos da sua comunidade:

\footnotetext{
$\overline{46}$ O primeiro projeto foi o sequenciamento da bactéria Xylella Fastidiosa, causadora da praga do amarelinho nas plantações de laranja, afetando, assim, um importante produto do agronegócio brasileiro.

47 A discussão sobre o estabelecimento de novas agendas de pesquisa na área da genética humana e médica, como, por exemplo, a genética do câncer, será trabalhada no terceiro capítulo.
} 
cientistas de um campo específico formam uma comunidade fechada, pesquisam uma amplitude bem definida de problemas, com métodos e instrumentos bem adaptados à tarefa. Sua definição dos problemas e seus métodos de pesquisa derivam de uma tradição profissional de teorias, técnicas e habilidades. E estas são adquiridas através de instrução prolongada (...). Os cientistas mais jovens são socializados na ciência; os cientistas mais maduros sustentam e transmitem essa tradição à geração seguinte (Ben-David, 1974, p. 15).

É nessa socialização na ciência que os indivíduos entram em contato com uma tradição profissional de teorias, técnicas e habilidades. Para Bourdieu (2003), por exemplo, uma das características que distingue o campo científico de outros campos é o fato de os requisitos de admissão no campo científico serem adquiridos por um longo processo de formação, que assegura aos novos cientistas o domínio da linguagem específica da ciência. $\mathrm{O}$ processo de formação dos cientistas também é uma dimensão central para Terry Shinn, em sua análise sobre a formação e a reprodução dos regimes de produção e distribuição do conhecimento científico (Shinn, 2008).

É uma assunção geral a de que uma carreira na ciência começa na universidade, local em que os estudantes recebem não apenas formação teórica, mas também educação prática, para dominar as habilidades necessárias de uma disciplina. Além disso, professores e pesquisadores mostram aos alunos um conjunto de regras e comportamentos que eles devem seguir ao longo de suas carreiras, assim como um conjunto de imagens do que significa ser um bom cientista. Considerando que a atividade de pesquisa é levada a cabo por agentes sociais com características particulares, a descrição da emergência dessa atividade supõe explicar a produção desse tipo de agente e sua relação com o campo científico (Gingras, 1991). Passo, portanto, a discutir esse aspecto da minha amostra.

Tabela 12: Cursos de Graduação frequentados (2015)

\begin{tabular}{lcc|} 
Graduação & No. & $\%$ \\
\hline Ciências biológicas & 185 & 48.6 \\
\hline Medicina & 104 & 27,3 \\
Biomedicina & 37 & 9,7 \\
Farmácia & 25 & 6,6 \\
\hline História Natural & 6 & 1,6 \\
\hline Veterinária & 4 & 1 \\
Química & 3 & 0,8 \\
Agronomia & 3 & 0,8 \\
\hline Física & 2 & 0,5 \\
\hline Odontologia & 2 & 0,5 \\
Matemática & 2 & 0,5 \\
Outros/Não informado & 8 & 2,1 \\
\hline Total & 381 & 100 \\
\hline
\end{tabular}


Fonte: Plataforma Lattes.

Elaboração própria.

Considerando o curso de graduação realizado, os pesquisadores em genética humana e médica distribuem-se da seguinte maneira: 48,6\% são formados em cursos de ciências biológicas, $27,3 \%$ se formaram em medicina, $9,7 \%$ se formaram em biomedicina, e $6,6 \%$ se formaram em farmácia ${ }^{48}$. No que diz respeito às demais formações, a dispersão é bastante considerável, com 7,8\% da amostra distribuída em outros 15 cursos de graduação.

Quando o olhar se volta aos cursos de pós-graduação, a distribuição é semelhante, sendo que mais da metade dos pesquisadores em genética humana fez seu doutorado em programas de pós-graduação em genética (Genética, Biologia Genética, Genética Humana, Genética e Biologia Molecular, Genética e Evolução, entre outros). Destacam-se, também, as diferentes especialidades médicas (Clínica Médica, Pediatria, Cardiologia, Oncologia, entre outros), formando $16,8 \%$ dos pesquisadores em nível de doutorado ${ }^{49}$.

Tabela 13: Programas de Pós-Graduação frequentados (2015)

\begin{tabular}{|c|c|c|}
\hline PPG & No. & $\%$ \\
\hline Genética & 204 & 53,5 \\
\hline Especialidades médicas & 55 & 14,4 \\
\hline Bioquímica & 23 & 6,1 \\
\hline Biologia Molecular & 14 & 3,7 \\
\hline Biofísica & 14 & 3,7 \\
\hline Neurociências & 8 & 2,1 \\
\hline Ciências Biológicas & 8 & 2,1 \\
\hline Biotecnologia & 8 & 2,1 \\
\hline Patologia & 8 & 2,1 \\
\hline Morfologia & 7 & 1,8 \\
\hline Farmacologia & 6 & 1,6 \\
\hline Outros & 26 & 6,8 \\
\hline Total & 381 & 100 \\
\hline
\end{tabular}

Fonte: Plataforma Lattes.

Elaboração própria.

É interessante notar que se há, de um lado, concentração nos programas voltados à genética, há, de outro, bastante dispersão quando se trata das outras áreas. Esse é mais um indício importante de que se trata de pesquisa realizada nos moldes disciplinares, ainda que, por não ter fronteiras de todo rígidas, receba contribuições de outras disciplinas e especialidades.

\footnotetext{
48 Na tabela 12, a categoria "Outros" inclui aqueles pesquisadores que não informaram seus cursos de graduação no currículo Lattes, e as formações com apenas um caso, como computação e enfermagem.

49 A categoria "Outros" inclui programas de pós-graduação com cinco pesquisadores ou menos, como é o caso de Microbiologia, Ciências Nucleares, Fisiologia e Medicina Veterinária.
} 
Tabela 14: Curso de Graduação e Pós-Graduação frequentados (2015)

\begin{tabular}{|c|c|c|c|c|c|c|c|c|c|c|c|}
\hline \multirow[b]{2}{*}{ Curso graduação } & \multicolumn{11}{|c|}{ Curso de pós graduação } \\
\hline & Genética & Medicina & Bioquímica & $\begin{array}{l}\text { Biologia } \\
\text { Molecular }\end{array}$ & Biofísica & Morfologia & $\begin{array}{l}\text { Ciências } \\
\text { Biológicas }\end{array}$ & Neurociências & Biotecnologia & Outros & Total \\
\hline Ciências & & & & & & & & & & & \\
\hline Biológicas & 120 & 7 & 8 & 8 & 10 & 4 & 5 & 0 & 6 & 17 & 185 \\
\hline Medicina & 37 & 38 & 4 & 3 & 1 & 1 & 1 & 6 & 1 & 12 & 104 \\
\hline Biomedicina & 22 & 5 & 3 & 2 & & 2 & & 1 & & 2 & 37 \\
\hline Farmácia & 8 & 4 & 4 & 1 & 1 & & 1 & 1 & 1 & 4 & 25 \\
\hline Total & 204 & 55 & 23 & 14 & 14 & 7 & 8 & 8 & 8 & 40 & 381 \\
\hline
\end{tabular}

Fonte: Plataforma Lattes.

Elaboração própria.

Na tabela acima foi realizado o cruzamento dos dados da graduação com aqueles da pós-graduação e, a partir dele, é possível delinear três perfis de formação mais comuns na genética humana. O primeiro deles é o do pesquisador que cursou ciências biológicas no nível da graduação e realizou seus estudos doutorais em programas de pós-graduação em genética. O segundo perfil é daqueles formados em medicina e que, ao se interessar pela disciplina de genética humana, migraram - no doutorado - para programas de genética, geralmente vinculados a institutos de biologia. Por fim, tem-se o terceiro perfil, o dos pesquisadores que se graduaram em medicina e continuaram seus estudos em programas de pós-graduação inseridos também em faculdades de medicina. Esses três perfis estão representados nas entrevistas realizadas para esta pesquisa, abordadas nos dois próximos capítulos.

Parte da literatura em sociologia da ciência enfatiza a necessidade de considerar a formação disciplinar como constitutiva das experiências, visões e práticas de pesquisa. Ao contrário dos estudos que enfatizam a interdisciplinariedade e um declínio das disciplinas, esses autores destacam a importância dessas instituições que, por meio de longos processos formativos, conformam os esquemas de percepção e os modos de atuação dos pesquisadores (Marcovich \& Shinn, 2012).

Com relação, ainda, à formação de pesquisadores, no nível do doutorado é importante destacar mais algumas informações, que revelam certas especificidades institucionais e geográficas. Dos 14 pesquisadores com doutorado em biofísica, 13 deles realizaram seus estudos na UFRJ, ou seja, mais do que uma íntima relação entre a biofísica e a genética humana, tem-se um perfil institucional específico, dessa universidade fluminense, de realizar também pesquisas em genética no Programa de Pós-Graduação de Ciências Biológicas (Biofísica). Essa instituição conta, igualmente, com um programa de pós-graduação de ciências biológicas com ênfase em genética, que formou 11 dos pesquisadores da amostra 
aqui analisada. Processo semelhante se dá com os pesquisadores que realizaram doutorado em Morfologia: do total de 7 pesquisadores, 6 realizaram seu doutorado na Unifesp.

Por fim, destaca-se que há sete pesquisadores graduados em história natural, todos com doutorado em genética. Trata-se de pesquisadores mais velhos, já aposentados, que frequentaram esse curso, que na maior parte das universidades brasileiras foi extinto até a década de 1960. O curso de História Natural esteve presente nas universidades brasileiras de criação mais antiga e integrava o que hoje são as disciplinas de biologia, geologia, zoologia e botânica. O primeiro curso foi criado na USP, em 1935, congregando os seguintes departamentos: mineralogia e metrografia, geologia e paleontologia, biologia geral, zoologia, botânica e fisiologia geral e animal; ele permaneceu com esse nome até 1957, quando foi desmembrado em dois cursos - Ciências Biológicas e Ciências Geológicas (Tomita, 1990). Processo semelhante ocorreu com os demais cursos de História Natural.

No que diz respeito às instituições em que foram realizados os cursos de graduação, é notável que, dos 381 pesquisadores, apenas 38 se formaram em instituições particulares e/ou confessionais de ensino superior. Esse número cai para apenas três pesquisadores, quando o olhar se volta para o tipo de instituição de realização do doutorado, o que mostra que não só a pesquisa em genética humana e médica é realizada majoritariamente em instituições públicas, como também o é a formação desses pesquisadores.

\subsubsection{Formação e requisitos para entrada na carreira}

Analisando os concursos para a área de genética nos últimos dois anos, é possível afirmar que as credenciais para a inserção no campo estão definidas, no mínimo, pelo doutorado. No entanto, quando o olhar se volta para a amostra selecionada é possível afirmar que há um contingente significativo de pesquisadores que encontrou um posto permanente de trabalho antes da obtenção de um nível doutoral. Na tabela abaixo é possível ver, no total de pesquisadores, a proporção deles que já era doutor ao ingressar na universidade, e aqueles que obtiveram esse diploma quando já estavam trabalhando, e também, essa proporção desagregada por região geográfica.

Tabela 15: Inserção profissional e titulação (2015) 


\begin{tabular}{lcccccccccccc|} 
& Total & $\%$ & CO & $\%$ & N & $\%$ & NE & $\%$ & S & $\%$ & SE & $\%$ \\
Doutor(a) & 247 & 64,8 & 15 & 71,4 & 15 & 51,7 & 38 & 61,3 & 38 & 52,1 & 142 & 72,4 \\
Não doutor(a) & 134 & 35,2 & 6 & 28,6 & 14 & 48,3 & 24 & 38,7 & 35 & 47,9 & 54 & 27,6 \\
Total & 381 & 100 & 21 & 100 & 29 & 100 & 62 & 100 & 73 & 100 & 196 & 100 \\
\hline
\end{tabular}

Fonte: Plataforma Lattes e Portal da Transparência Elaboração própria.

Nessa mesma tabela é possível verificar, também, diferenças regionais significativas. Nas regiões Norte e Sul, quase metade dos pesquisadores se inseriram institucionalmente antes da realização de seu doutorado (embora todos tenham se tornado doutores posteriormente), enquanto na região Sudeste, em que se encontra a maior parte dos pesquisadores da amostra, a proporção daqueles que não tinham doutorado no momento de entrada na carreira é de aproximadamente $25 \%$.

Há, também, diferenças quando se considera a inserção departamental, sendo que a proporção de não doutores no momento da entrada em uma instituição é maior nos departamentos vinculados a faculdades de medicina, se comparados aos departamentos em institutos de biologia e similares, como pode ser visto na tabela abaixo.

Tabela 16: Inserção profisssional e titulação - por departamento (2015)

\begin{tabular}{lccccc} 
& Biologia & $\%$ & Medicina & $\%$ & Total \\
Doutor(a) & 191 & 69,2 & 56 & 53,3 & 247 \\
\hline Não doutor(a) & 85 & 30,8 & 49 & 46,7 & 134 \\
\hline Total & 276 & 100 & 105 & 100 & 381 \\
\hline
\end{tabular}

Fonte: Plataforma Lattes e Portal da Transparência Elaboração própria.

Mas, sem dúvida, a principal diferença transparece quando se cruza o fato de ter ou não terminado o doutorado antes da obtenção do trabalho atual, com a década de entrada na instituição, como mostrado na tabela a seguir.

Tabela 17: Década da inserção profissional e titulação

$\begin{array}{lcccccccc} & 1950 & 1960 & 1970 & 1980 & 1990 & 2000 & \mathbf{2 0 1 0} & \text { Total } \\ \text { Doutor(a) } & 0 & 0 & 0 & 17 & 34 & 97 & 99 & 247 \\ \text { Não doutor(a) } & 2 & 2 & 20 & 36 & 45 & 22 & 7 & 134 \\ \text { Total } & 2 & 2 & 20 & 53 & 79 & 119 & 106 & 381\end{array}$

Fonte: Plataforma Lattes e Portal da Transparência Elaboração própria. 
Até a década de 1990, a quantidade de pesquisadores que começaram a trabalhar em universidades, institutos de pesquisa ou hospitais antes da conclusão de seu doutorado é superior àqueles que tiveram sua inserção institucional posteriormente ao doutorado. Essa tendência se inverte completamente nos anos 2000, sendo que a partir de 2010 cerca de $94 \%$ deles eram doutores previamente, contra 43\% em 1990. Tal fato expressa o avanço da institucionalização da carreira acadêmica no país e o consequente aumento dos níveis de titulação, que passam a se tornar requisitos profissionais de entrada no campo universitário.

\subsubsection{Formação dos pesquisadores: relação com o internacional}

Uma dimensão essencial do estudo do processo de formação dos pesquisadores é, também, o grau de internacionalização da sua pós-graduação:

Desde a emergência da ciência moderna no período da revolução científica, a formação de pessoas para desempenhar atividades de investigação é feita por outros pesquisadores, através de uma relação do tipo "mestre e aprendiz". Tendo em vista que a competência dos pesquisadores qualificados, por uma série de razões, não é homogênea no mundo, o esforço de formação de pesquisadores de um dado país sempre contou, em alguma medida, com a expertise instalada em outros países (Velho, 2001, p. 607).

A passagem pelo exterior foi considerada importante do ponto de vista da capacitação de pesquisadores segundo padrões internacionais, e do ponto de vista da formação individual, ou seja, do impacto que o contato com outras instituições e culturas científicas pode vir a ter sobre a atuação dos pesquisadores na volta ao país de origem (Velho, 2001). Conforme um país qualifica seus próprios pesquisadores, vai adquirindo competências que, somadas às outras condições necessárias (emprego, financiamento, reconhecimento social etc.), tornam possível a formação de pesquisadores dentro de suas próprias fronteiras. Essa é a trajetória histórica da maioria dos países que conseguiu estabelecer um sistema significativo de formação de novos pesquisadores (Velho, 2001; Trindade, 2004).

Analisando o local de realização do doutorado, é possível constatar que a imensa maioria - 347 pesquisadores ou $91,1 \%$ - fez sua formação no país ${ }^{50}$. As informações gerais sobre a pequena parcela de doutores brasileiros no exterior - em formação ou titulados - são insuficientes e fragmentadas em estudos ocasionais (Schwartzman, 1979; Guimarães, 2002; Velloso, 2006); sabe-se, no entanto, que são estatisticamente muito poucos, principalmente

50 Foram excluídos os pesquisadores estrangeiros trabalhando com genética humana e médica em instituições brasileiras. Ainda que seus doutorados tenham sido realizados no exterior, inclúí-los aqui poderia não retratar bem a distribuição da realização do doutorado integral fora do país, enquanto política pública brasileira. 
quando comparados ao contingente de doutores de outros países, inclusive competidores emergentes, tais como China e Índia (Ramos \& Velho, 2011).

A distribuição entre os pesquisadores da amostra reflete, em parte, a alteração na política de internacionalização da pós-graduação brasileira, com a substituição progressiva do doutorado pleno no exterior por outras opções como o doutorado parcial - conhecido como doutorado-sanduíche - e o pós-doutorado. O argumento central dos defensores dessa política é que o custo de financiamento da bolsa de doutorado-sanduíche é menor, evita a permanência de doutores no exterior e os problemas de falta de adaptação no retorno ${ }^{51}$, ao mesmo tempo em que propicia aos doutorandos treinamento e experiência de estudo/pesquisa no exterior (Velho, 2001). Ou seja, ganhar-se-ia o mesmo que com o doutorado pleno, com algumas vantagens e a um custo significativamente menor, inclusive aumentando, poder-se-ia argumentar, a eficiência do investimento público em ciência e tecnologia.

Há um número significativamente maior de pesquisadores que realizaram doutoradosanduíche, se comparado ao percentual daqueles que realizaram o doutorado integral em instituições estrangeiras: 68 pesquisadores $(17,9 \%)$ da amostra realizaram doutoradosanduíche, contra 32 pesquisadores $(8,4 \%)$ que cursaram o doutorado integral no exterior.

Tabela 18: Doutorado ou doutorado-sanduíche em instituições estrangeiras (2015)

\begin{tabular}{|ccccccc|} 
& Centro-Oeste & Norte & Nordeste & Sul & Sudeste & Total \\
\hline $\begin{array}{c}\text { Sanduíche } \\
\text { Doutorado }\end{array}$ & 7 & 0 & 9 & 17 & 35 & 68 \\
$\begin{array}{c}\text { Integral } \\
\text { Sem formação }\end{array}$ & 0 & 4 & 2 & 7 & 19 & 32 \\
internacional & 14 & 25 & 51 & 49 & 142 & 281 \\
Total & 21 & 29 & 62 & 73 & 196 & 381
\end{tabular}

Fonte: Plataforma Lattes.

Elaboração própria.

Destaca-se, na tabela acima, a distribuição geográfica dos pesquisadores que realizaram ao menos parte de seu doutorado em uma instituição estrangeira. A distribuição segue, em geral, a distribuição geográfica dos pesquisadores da amostra, mas com pequenos desvios, como pode ser visto na tabela abaixo. Tanto a região Norte quanto a região Nordeste têm proporcionalmente menos pesquisadores com experiência internacional, se comparado com a distribuição geográfica. O fato de as regiões Sul e Sudeste terem proporcionalmente

51 Em que pese, aqui, o fato de que muitas vezes essa dificuldade de adaptação é, na verdade, dificuldade de encontrar empregos condizentes com a formação dos pesquisadores, posteriormente ao término do doutorado no exterior. 
mais pesquisadores com formação internacionalizada pode ser explicado, ao menos em parte, pela distribuição desigual do orçamento em Ciência \& Tecnologia no país.

A partir dos dados levantados, não é possível afirmar que se apresentem elementos claros de uma mudança no que diz respeito à política de financiamento da internacionalização da pesquisa, podendo-se falar apenas em alguns indícios de alterações. A tabela abaixo divide, na segunda coluna, os pesquisadores da amostra por década de início do doutorado, tanto no Brasil quanto no exterior. A terceira e quarta coluna apresentam a quantidade de pesquisadores que realizaram, respectivamente, doutorado integral e estágio doutoral no exterior. Se não é possível analisar esses dados em termos de mudança de política pública do doutorado integral para o doutorado-sanduíche - é notável o crescimento de estágio doutoral de longa duração (seis meses ou mais) a partir dos anos $1990^{52}$.

Tabela 19: Década de início do doutorado

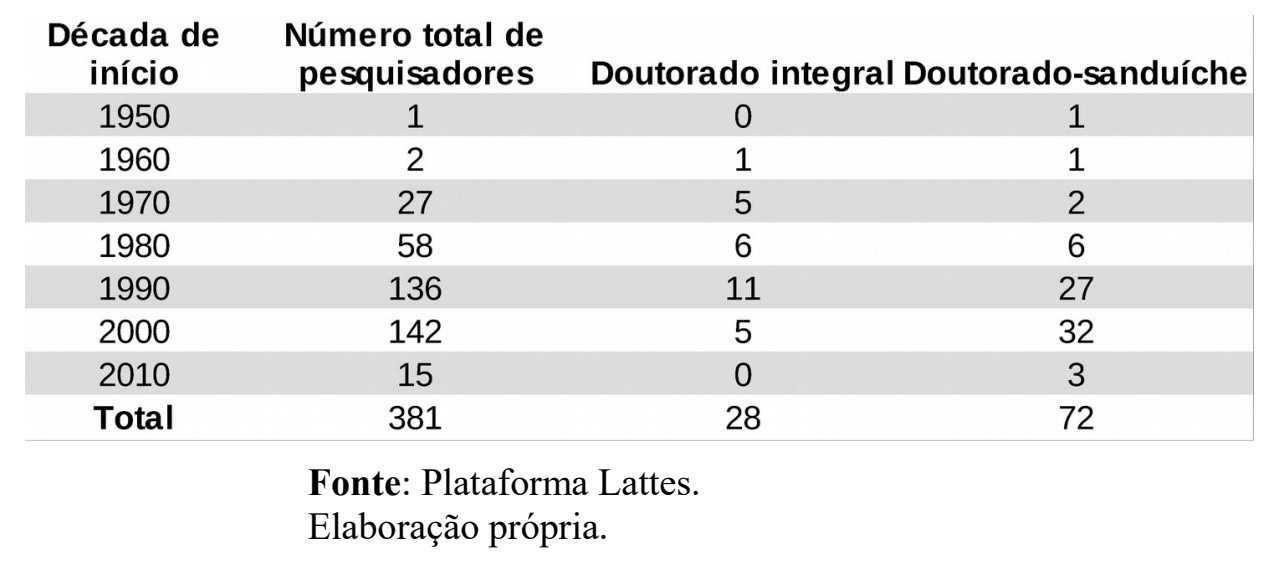

As 100 experiências internacionais em nível de doutorado são divididas em 81 instituições diferentes, indicando que não há trajetórias homogêneas quando se trata de inserção internacional. Os únicos destaques em termos de instituição são a University of London, na Inglaterra (conglomerado de faculdades/institutos, como University College London, Imperial College London e King's College London), com sete pesquisadores que lá realizaram parte de sua formação; a Ludwig-Maximilians-Universität München, na Alemanha, com quatro; bem como a New York University, nos EUA, com três pesquisadores.

Se a dispersão institucional dessas experiências internacionais é grande, o mesmo não pode ser dito da dispersão geográfica. Dos pesquisadores que fizeram ao menos parte de sua

52 Os números mais baixos em 2010 devem-se ao fato de que muitos daqueles que iniciaram seu doutorado nessa década estão em fase de finalização, ou ainda não encontraram espaços de trabalho mais ou menos permanentes para serem inseridos na amostra aqui analisada. De toda forma, é possível supor que o número de doutorados-sanduíche para essa década tende a ser mais alto do que o da década anterior. 
formação doutoral no exterior, 50\% estudaram na América do Norte, $47 \%$ na Europa, com destaque para Inglaterra e Alemanha, e apenas 3\% em países de outros continentes - Austrália e Israel. É notável, ao olhar para esses dados, que nenhum pesquisador tenha realizado sua formação doutoral em países tidos como mais periféricos, na América Latina, ou em outros países menos centrais da própria Europa. A exceção se dá, talvez, com vistas aos países latinos da Europa, tal como Portugal e Espanha, que, do ponto de vista do sistema mundial da ciência, podem ser considerados como países semiperiféricos. A expressão "semiperiferia" é usada por João Arriscado Nunes e Maria Eduarda Gonçalves (2001) para caracterizar a posição da ciência portuguesa num sistema mundial organizado em zonas centrais, periféricas ou semiperiféricas, em uma análise sobre a globalização da ciência, que produz centralidade e marginalização.

Tabela 20: País em que foi realizado o doutorado integral ou sanduíche (2015)

\begin{tabular}{|ccc|}
$\begin{array}{c}\text { País realização } \\
\text { doutorado }\end{array}$ & $\begin{array}{c}\text { Pesquisadores } \\
\text { EUA }\end{array}$ & $\%$ \\
\hline Alemanha & 12 & 42 \\
\hline Inglaterra & 11 & 12 \\
\hline Canadá & 8 & 11 \\
\hline França & 7 & 8 \\
\hline Itália & 6 & 7 \\
\hline Suíça & 2 & 6 \\
\hline Espanha & 2 & 2 \\
\hline Portugal & 2 & 2 \\
\hline Holanda & 2 & 2 \\
\hline Austrália & 2 & 2 \\
\hline Irlanda & 1 & 2 \\
\hline Escócia & 1 & 1 \\
\hline Suécia & 1 & 1 \\
\hline Israel & 1 & 1 \\
\hline Total & 100 & 1 \\
\hline
\end{tabular}

Fonte: Plataforma Lattes.

Elaboração própria.

Nesse sentido, é possível afirmar que o movimento não se dá aleatoriamente. Possui características que são, em parte, reflexos do estágio de desenvolvimento educacional, científico e tecnológico e das políticas correlatas, implantadas nos países de origem e de destino. Assim, e em maior proporção, o fluxo ocorre em direção aos que dispõem de condições mais favoráveis para a pesquisa, em termos de recursos físicos e financeiros, e pela existência de polos universitários capazes de proporcionar uma formação vista como superior à encontrada no país de origem (Altbach, 2006). 
Como dito na introdução, essa circulação de estudantes e pesquisadores não e um fenômeno novo (Karady, 2002), mas as viagens vêm se tornando cada vez mais um fenômeno institucionalizado, e, no caso brasileiro, apoiado por políticas de internacionalização das principais agências de fomento e universidades (Ramos, 2018). Mas, para melhor compreender esses movimentos, é preciso levar em conta a hierarquia internacional. Imagens da globalização sugerem um processo que homogeneiza e equaliza o mundo, mas os dados sobre esses deslocamentos mostra que eles não vêm sendo aleatórios, seguindo determinadas rotas: os estudantes têm viajado principalmente para os Estados Unidos, Canadá e alguns países da Europa (Schott, 1998; Connell \& Wood, 2002). Essa característica identificada em estudos mais gerais sobre a globalização da ciência e mobilidade internacional, está fortemente presente nos pesquisadores da área de genética humana e médica situados no Brasil. Os fluxos de pesquisadores para esses países são um elemento importante da dinâmica de produção e reprodução das relações entre centros e periferias, discussão essa que será retomada no próximo capítulo, a partir da análise das entrevistas realizadas.

\subsubsection{Inserção internacional e regional: o pós-doutorado}

O contato com o "internacional", entre os pesquisadores da amostra, se dá menos no momento da formação doutoral do que no pós-doutorado. Dos 381 pesquisadores selecionados, 36,5\% realizaram ao menos um pós-doutorado no exterior, proporção essa mais acentuada do que os $26,2 \%$ que realizaram ao menos parte de seu doutorado em instituições estrangeiras. Ao realizar a distribuição por região geográfica, há diferenças, com um percentual mais significativo de pesquisadores do Sudeste que realizaram pós-doutorado no exterior, se comparado à região Norte, por exemplo.

Tabela 21: Pós-doutorado no exterior - por região geográfica (2015)

\begin{tabular}{lccccc} 
Região & Sim & \% & Não & $\%$ & $\begin{array}{c}\text { Total } \\
\text { pesquisadores }\end{array}$ \\
Centro Oeste & 8 & 38,1 & 13 & 61,9 & 21 \\
Norte & 5 & 17,2 & 24 & 82,8 & 29 \\
Nordeste & 18 & 29 & 44 & 71 & 62 \\
Sul & 23 & 31,5 & 50 & 68,5 & 73 \\
Sudeste & 85 & 43,4 & 111 & 56,6 & 196 \\
Total & 139 & & 242 & & 381 \\
\hline
\end{tabular}

Fonte: Plataforma Lattes.

Elaboração própria. 
Essa proporção ganha mais sentido analítico quando comparada com o conjunto de pesquisadores que realizaram pós-doutorado. Dos pesquisadores da amostra, 220 ou 57,7\% realizaram ao menos um pós-doutorado ${ }^{53}$. Desse conjunto de pesquisadores com ao menos um pós-doutorado, é notável que $63,2 \%$ realizaram ao menos um pós-doutorado fora do país ${ }^{54}$, como pode ser verificado na tabela abaixo.

Tabela 22: Proporção de pós-doutorados dentro e fora do país (2015)

\begin{tabular}{|ccc|}
\hline & N. pesquisadores & $\%$ \\
\hline No exterior & 139 & 63,2 \\
\hline No Brasil & 81 & 36,8 \\
\hline Total & 220 & 100 \\
\hline
\end{tabular}

Fonte: Plataforma Lattes.

Elaboração própria.

Quando se trata dos países em que se localizam as instituições-sede que receberam esses pesquisadores, a distribuição não é muito diferente daquela observada para a formação doutoral na modalidade integral ou sanduíche.

Tabela 23: Países em que foram realizados os pós-doutorados (2015)

\begin{tabular}{lc|}
\hline Países & N. pós-doc. \\
\hline EUA & 106 \\
\hline Inglaterra & 22 \\
\hline França & 10 \\
Canadá & 9 \\
Alemanha & 7 \\
Itália & 6 \\
Portugal & 6 \\
Holanda & 5 \\
Espanha & 4 \\
Austrália & 4 \\
Japão & 3 \\
Suíça & 3 \\
Outros países & \\
europeus & 6 \\
Total & 191 \\
\hline
\end{tabular}

Fonte: Plataforma Lattes. Elaboração própria.

53129 pesquisadores realizaram um pós-doutorado; 66 realizaram dois; 25 realizaram três ou mais, sendo o número mais alto o de seis pós-doutorados realizados por um mesmo pesquisador.

54 Destaca-se que nesta tabela não há total de pesquisadores que realizaram ao menos um pós-doutorado no Brasil, apenas aqueles que realizaram somente pós-doutorado no Brasil (e nenhum no exterior). Os casos excluídos da segunda linha da tabela são daqueles que, embora tenham realizado um pós-doutorado no Brasil, também tiveram essa experiência no exterior. Entre os 139 pesquisadores que realizaram pósdoutorado no exterior, 35 deles realizaram, também, ao menos um pós-doutorado no Brasil. 
É notável a quantidade de pós-doutorados realizados nos Estados Unidos, seguidos de Inglaterra, França e Canadá, e a completa ausência de instituições de países da América Latina. Novamente destaca-se que o fluxo dos pesquisadores se orienta aos centros com maior intensidade de conhecimento - que fixam os padrões e paradigmas; são deslocamentos geográficos que configuram movimentos de circulação que obedecem à hierarquia internacional das relações científico-tecnológicas (Meyer, Kaplan \& Charun, 2001).

Quando se trata das instituições nacionais em que foram realizados os pós-doutorados, a orientação em direção ao centro se mantém, com grande destaque para instituições localizadas no estado de São Paulo, sobretudo para a USP, que conta com 49 dos 146 pósdoutorados realizados no Brasil, conforme pode ser visto na tabela, em que são destacadas as instituições nacionais mais frequentes para a realização do pós-doutorado.

Tabela 24: Instituições nacionais de realização do pós-doutorado (2015)

\begin{tabular}{lc|}
$\begin{array}{l}\text { Instituições } \\
\text { brasileiras }\end{array}$ & $\begin{array}{c}\text { Quantidade } \\
\text { pós-doc }\end{array}$ \\
USP & 49 \\
UFRGS & 16 \\
Unicamp & 9 \\
Unifesp & 8 \\
INCA & 7 \\
Unesp & 6 \\
UFMG & 5 \\
UFPR & 5 \\
UFSC & 5 \\
Outros & 36 \\
Total & 146 \\
\hline
\end{tabular}

Fonte: Plataforma Lattes. Elaboração própria.

Essas tendências, referentes aos países de destino e às instituições brasileiras, sugerem que o processo de circulação dos pesquisadores é marcado por uma lógica centrípeta, pela qual os pesquisadores tendem a caminhar em direção aos centros do sistema de pesquisa, ainda que esse centro varie e seja definido de acordo com o ponto de partida (Carlotto, 2013, p. 269). Nesse sentido, pesquisadores de outras regiões do país tendem a migrar para o Sudeste, particularmente para as universidades estaduais paulistas, que são o núcleo central do regime disciplinar/estatal brasileiro do ponto de vista da quantidade e qualificação dos pesquisadores, de número de programas de pós-graduação e infraestrutura de pesquisa.

Na tabela acima, além das instituições localizadas no estado de São Paulo, destaca-se a UFRGS como centro importante de formação e pesquisa. Isso se explica, em parte, pelo fato 
de o Programa de Pós-Graduação em Genética e Biologia Molecular da instituição ser bastante antigo, datando de 1954, e ter nota sete no sistema de avaliação Capes. Trata-se, no entanto, de uma instituição bastante endógena. Dos 16 pós-doutorados realizados na instituição, 14 deles foram feitos por pesquisadores cuja formação de mestrado e doutorado se localizam na instituição. Dos dois restantes, um pesquisador realizou sua formação doutoral em outra instituição do Rio Grande do Sul, e outro em universidade da Argentina. Essa endogenia não desaparece, no entanto, nas outras instituições presentes na tabela acima, o que mostra uma tendência de fraca mobilidade institucional e regional, como será melhor visto mais à frente.

A análise do pós-doutorado permite, além da verificação da experiência internacional, constatar dois padrões de formação e carreira. $\mathrm{Na}$ área de genética humana e médica, as credenciais para a inserção no campo estão definidas, no mínimo, pelo doutorado ${ }^{55}$, mas, devido ao crescimento quantitativo da formação de doutores no país, à escassa disponibilidade de postos na carreira acadêmica e à consequente competição, o pós-doutorado aparece progressivamente como etapa igualmente fundamental. Ao olhar para o momento de realização do pós-doutorado, é possível constatar que, quando se trata de pesquisadores inseridos em instituições de ensino superior há mais tempo, a maioria realizou seu primeiro pós-doutorado já trabalhando. Enquanto isso, os pesquisadores de carreira mais recente realizaram o(s) seu(s) - às vezes mais de um - pós-doutorado(s) antes de encontrar espaço em alguma instituição de pesquisa.

Tabela 25: Inserção profissional durante o pós-doutorado (2015)

\begin{tabular}{lcc} 
& $\begin{array}{c}\text { Estava trabalhando? } \\
\text { Sim }\end{array}$ & $\begin{array}{c}\text { Não } \\
2010\end{array}$ \\
\hline 2000 & 19 & 63 \\
1990 & 25 & 49 \\
1980 & 23 & 17 \\
1970 & 11 & 5 \\
1960 & 0 & 0 \\
1950 & 2 & 0 \\
Total & 86 & 0 \\
\hline
\end{tabular}

Fonte: Plataforma Lattes. Elaboração própria.

55 Embora essa seja uma tendência mais recente, como apresentado no item 1.2.6. 
A tabela acima indica que, quanto mais recente a carreira do pesquisador, maior a probabilidade que ele realize o pós-doutorado - seja no Brasil, seja no exterior - como parte dos requisitos mínimos para a inserção profissional mais estável nas instituições de ensino superior. Nesse sentido, é possível perceber a coexistência de dois padrões de carreira distintos, e de significações também distintas para a realização do pós-doutorado. O primeiro padrão de carreira e significado do pós-doutorado se dá entre aqueles que tiveram uma inserção profissional permanente mais rápida, até dois anos após o término do doutorado, e realizam um pós-doutorado - notadamente no exterior - com objetivos mais próximos de uma atualização ou aquisição de novos conhecimentos, ou, ainda, para a expansão de linhas de pesquisa, como será visto no próximo capítulo.

O pós-doutorado, para aqueles que ainda não encontraram inserção mais estável no mercado de trabalho, aparece como uma possibilidade transitória de se manter na carreira, fazendo pesquisa com uma remuneração. Ao mesmo tempo, ele implica a insegurança da condição temporária de bolsista, sem vínculo empregatício ${ }^{56}$. Os pesquisadores da amostra superaram a condição temporária e instável do pós-doutorado, mas alguns deles tiveram que esperar alguns anos - e algumas bolsas - para tal. É possível aventar como hipótese a de que esse segundo padrão de carreira explica, ao menos em parte, a endogenia no que tange à instituição brasileira de realização do pós-doutorado, que, mais do que uma nova experiência, permite que o pesquisador continue desenvolvendo pesquisas na instituição em que se formou no doutorado, à espera de uma vaga permanente nessa ou em outra instituição ${ }^{57}$.

Destaca-se, ainda, que a maior parte dos pesquisadores que realizaram pós-doutorado no Brasil o fizeram antes da inserção profissional permanente, cenário diferente de quando se trata de pós-doutorado no exterior. Do total de 144 pós-doutorados realizados no território nacional, apenas 10 (ou 6,9\%) deles foram realizados quando o pesquisador já tinha vínculo empregatício. Esse dado evidencia uma característica tanto das escolhas individuais quanto da política pública brasileira de privilegiar o pós-doutorado no exterior.

56 Em artigo escrito previamente, discuto, a partir de um laboratório da USP, os padrões de formação e carreira dos jovens pesquisadores em genética humana e médica, notadamente a percepção, entre aqueles que já realizaram diversos pós-doutorados, de que, apesar de adultos, são percebidos e se percebem na condição de estudantes (Ferreira, 2015).

57 Daqueles que realizaram pós-doutorado no Brasil, $65 \%$ o fizeram na mesma instituição em que obtiveram seu diploma de doutorado. 


\subsubsection{Padrões de trajetórias formativas}

Nesta seção continua-se a análise de alguns padrões de trajetória dos pesquisadores em genética humana e médica situados no Brasil. Na tabela abaixo estão presentes as etapas mais comuns em termos de trajetória de formação, desde a graduação ao pós-doutorado.

Tabela 26: Padrões de trajetória dos pesquisadores em genética humana $(2016)^{58}$

\begin{tabular}{|c|c|c|}
\hline Trajetória & N. pesquisadores & $\%$ \\
\hline Graduação - Mestrado - Doutorado & 145 & 38,1 \\
\hline $\begin{array}{c}\text { Graduação - Mestrado - Doutorado - } \\
\text { pós-doutorado no exterior }\end{array}$ & 81 & 21,3 \\
\hline $\begin{array}{c}\text { Graduação - Mestrado - Doutorado - } \\
\text { pós-doutorado no Brasil }\end{array}$ & 67 & 17,6 \\
\hline $\begin{array}{c}\text { Graduação - Doutorado - pós- } \\
\text { doutorado no exterior }\end{array}$ & 26 & 6,8 \\
\hline $\begin{array}{c}\text { Graduação - Doutorado - Pós- } \\
\text { doutorado }\end{array}$ & 16 & 4,2 \\
\hline $\begin{array}{l}\text { Graduação - Mestrado - Doutorado no } \\
\text { exterior - pós-doutorado exterior }\end{array}$ & 13 & 3,4 \\
\hline Graduação - Doutorado & 11 & 2,9 \\
\hline $\begin{array}{c}\text { Graduação - Doutorado no exterior - } \\
\text { pós-doutorado no exterior }\end{array}$ & 11 & 2,8 \\
\hline Outras & 11 & 2,9 \\
\hline Total & 381 & 100 \\
\hline
\end{tabular}

Fonte: Plataforma Lattes.

Elaboração própria.

O padrão de trajetória formativa mais recorrente é o dos pesquisadores que realizaram graduação, mestrado e doutorado, e não realizaram pós-doutorado $(38,1 \%)$. A segunda e a terceira trajetórias mais frequentes incluem a realização do pós-doutorado, seja no exterior $(21,3 \%)$, seja no próprio país $(17,6 \%)$. Somadas, elas equiparam-se ao total do primeiro padrão, indicando a institucionalização da formação estendida do pesquisador nos pósdoutorados. Outro ponto observável é que, embora o número de pesquisadores que não realizaram a etapa do mestrado seja significativo, não se tornou o mais frequente em termos de trajetória formativa.

58 Sempre que não mencionado, o diploma ou título em questão foi realizado no país. Quando havia mais de um tipo de vínculo, como duas graduações ou mais de um pós-doutorado, optou-se por considerar apenas o primeiro. Na categoria "Outras" estão incluídas as trajetórias mais excepcionais, com poucos casos encontrados, como: Graduação - Mestrado - Doutorado no exterior - pós-doutorado no Brasil (6 casos), Graduação - Mestrado - Doutorado no exterior (3 casos); Graduação - Doutorado no exterior (1 caso); Graduação - Doutorado no exterior - pós-doutorado no Brasil (1 caso). Nenhuma das trajetórias implica a não realização do doutorado, embora, como visto acima, ele possa ser realizado posteriormente ao vínculo empregatício em uma universidade. 
Em seu estudo sobre os pesquisadores do Laboratório Nacional de Luz Síncrotron (LNLS), Carlotto (2013, pp. 255-263) identificou tendências semelhantes nos padrões de formação. De um, lado, ela nota uma tendência recente para a "aceleração" da formação, devido à diminuição de prazos dos programas de pós-graduação e à figura do doutorado direto, eliminando o momento formativo do mestrado. No entanto, a autora afirma que esse fenômeno deve ser compreendido à luz de dois outros processos: a antecipação da formação, a partir dos programas de iniciação científica, que passa a ser quase um momento obrigatório, e o prolongamento da pós-graduação, por meio da realização de um ou mais pós-doutorados. Esses dados permitem que a autora afirme, a partir das trajetórias formativas dos pesquisadores do LNLS, que o tempo total de formação não se alterou, a despeito da diminuição generalizada dos prazos para a realização da pós-graduação.

A partir desses dados encontra-se, portanto, indícios de que há processos de transformação em andamento, tanto no que diz respeito à formação, quanto na própria carreira, que vai adquirindo, sobretudo no Sul e Sudeste, características mais semelhantes àquelas de países como os Estados Unidos, em que é recorrente a realização de diversos pósdoutorados e outros vínculos de inserção profissional temporários, antes da obtenção de uma posição permanente em uma instituição de ensino e pesquisa.

Não foram encontradas diferenças significativas nesses padrões de trajetória quando relacionados a variáveis como sexo e inserção departamental (se em instituto de biologia ou faculdade de medicina). As tabelas 28 e 29, abaixo, descrevem a correlação dos padrões de trajetória com região geográfica e as datas de finalização do doutorado, respectivamente. 
Tabela 27: Trajetórias divididas por década de término do doutorado $(2016)^{59}$

\begin{tabular}{|c|c|c|c|c|c|c|c|c|c|c|c|}
\hline & 1970 & $\%$ & 1980 & $\%$ & 1990 & $\%$ & 2000 & $\%$ & 2010 & $\%$ & Total \\
\hline $\begin{array}{c}\text { Graduação - Mestrado - } \\
\text { Doutorado }\end{array}$ & 2 & 16,7 & 10 & 25 & 37 & 35,9 & 64 & 38,1 & 32 & 58,2 & 145 \\
\hline $\begin{array}{c}\text { Graduação - Mestrado - } \\
\text { Doutorado - Pós-doutorado } \\
\text { no exterior }\end{array}$ & 7 & 58,3 & 17 & 43 & 27 & 26,2 & 24 & 14,2 & 6 & 10,9 & 81 \\
\hline $\begin{array}{l}\text { Graduação - Mestrado - } \\
\text { Doutorado - Pós-doutorado }\end{array}$ & 0 & & 1 & 2,5 & 10 & 9,7 & 44 & 26,2 & 12 & 21,8 & 67 \\
\hline $\begin{array}{l}\text { Graduação - Doutorado - } \\
\text { Pós-doutorado no exterior }\end{array}$ & 0 & & 2 & 5 & 7 & 6,8 & 14 & 8,3 & 0 & & 23 \\
\hline $\begin{array}{c}\text { Graduação - Doutorado - } \\
\text { Pós-doutorado }\end{array}$ & 0 & & 1 & 2,5 & 6 & 5,8 & 6 & 3,6 & 3 & 5,5 & 16 \\
\hline $\begin{array}{l}\text { Graduação - Mestrado - } \\
\text { Doutorado no exterior - } \\
\text { Pós-doutorado no exterior }\end{array}$ & 0 & & 2 & 5 & 6 & 5,8 & 4 & 2,4 & 1 & 1,8 & 13 \\
\hline Graduação - Doutorado & 0 & & 2 & 5 & 2 & 2 & 7 & 4,2 & 0 & & 11 \\
\hline $\begin{array}{l}\text { Graduação - Doutorado no } \\
\text { exterior - Pós-doutorado no } \\
\text { exterior }\end{array}$ & 3 & 25 & 3 & 7 & 4 & 3,9 & 1 & 0,6 & 0 & & 11 \\
\hline Outros & 0 & & 2 & 5 & 4 & 3,9 & 4 & 2,4 & 1 & 1,8 & 11 \\
\hline Total & 12 & 100 & 40 & 100 & 103 & 100 & 168 & 100 & 55 & 100 & 378 \\
\hline
\end{tabular}

Fonte: Plataforma Lattes.

Elaboração própria.

A tabela acima buscou apreender possíveis diferenças, em termos de carreira, entre o que podem ser consideradas - de forma indicativa - como gerações distintas de pesquisadores. Foi tomada como base a data de término do doutorado, e não a data do primeiro vínculo empregatício, de modo a não distorcer os dados em meio a certa demora para a entrada formal no mercado de trabalho, principalmente entre os pesquisadores que opta(ra)m por permanecer no Sudeste. A primeira diferença a ser destacada é a de que pesquisadores mais velhos, que terminaram o doutorado entre 1970 e 1980, têm como trajetória mais frequente aquela em que se realiza todas as etapas formativas no país e ao menos um pós-doutorado no exterior. Considero que, mais do que uma diferença entre gerações, se comparado à trajetória mais comum das décadas subsequentes - graduação, mestrado e doutorado no país -, é possível afirmar que esses pesquisadores mais velhos simplesmente têm mais tempo de carreira e, consequentemente, maiores oportunidades para a realização do pós-doutorado no exterior.

Nesse sentido, considera-se mais relevante o aumento da importância que o pósdoutorado no próprio país assumiu, inexistente entre aqueles que concluíram o doutorado na década de 1970, e subindo de 5\% das trajetórias daqueles que obtiveram o título de doutor na 
década de 1980, para 15,5\% em 1990, e 30\% em $2000^{60}$. Esse dado fortalece a reflexão feita anteriormente acerca da importância crescente que o pós-doutorado desempenha nas carreiras dos pesquisadores mais jovens, como elemento adicional de constituição dos currículos, antes da inserção profissional mais duradoura e formal. Simultaneamente, a queda, ao longo do tempo, no percentual de pessoas que realizaram seu doutorado integral fora do Brasil, pode ser lida como um reflexo do aumento das oportunidades de doutoramento no país, devido às políticas de expansão da pós-graduação no Brasil.

Tabela 28: Padrões de trajetória divididos por região geográfica (2016)

\begin{tabular}{|c|c|c|c|c|c|c|c|c|c|c|c|}
\hline & Sudeste & $\%$ & Sul & $\%$ & Norte & $\%$ & Nordeste & $\%$ & Centro-Oeste & $\%$ & Total \\
\hline $\begin{array}{c}\text { Graduação - Mestrado - } \\
\text { Doutorado }\end{array}$ & 54 & 27,6 & 34 & 46,6 & 16 & 55,2 & 33 & 53,2 & 8 & 38,1 & 145 \\
\hline $\begin{array}{c}\text { Graduação - Mestrado - } \\
\text { Doutorado - Pós-doutorado } \\
\text { no exterior }\end{array}$ & 44 & 22,4 & 14 & 19,2 & 5 & 17,2 & 11 & 17,8 & 7 & 33,3 & 81 \\
\hline $\begin{array}{c}\text { Graduação - Mestrado - } \\
\text { Doutorado - Pós-doutorado }\end{array}$ & 40 & 20,4 & 12 & 16,5 & 7 & 24,2 & 4 & 6,5 & 4 & 19 & 67 \\
\hline $\begin{array}{l}\text { Graduação - Doutorado - } \\
\text { Pós-doutorado no exterior }\end{array}$ & 17 & 8,7 & 3 & 4,1 & 0 & & 6 & 9,7 & 0 & & 26 \\
\hline $\begin{array}{c}\text { Graduação - Doutorado - } \\
\text { Pós-doutorado }\end{array}$ & 10 & 5,1 & 2 & 2,7 & 1 & 3,4 & 3 & 4,8 & 0 & & 16 \\
\hline $\begin{array}{l}\text { Graduação - Mestrado - } \\
\text { Doutorado no exterior - } \\
\text { Pós-doutorado no exterior }\end{array}$ & 11 & 5,6 & 2 & 2,7 & 0 & & 0 & & 0 & & 13 \\
\hline $\begin{array}{c}\text { Graduação - Doutorado no } \\
\text { exterior - Pós-doutorado } \\
\text { no exterior }\end{array}$ & 7 & 3,6 & 3 & 4,1 & 0 & & 1 & 1,6 & 0 & & 11 \\
\hline Outros & 5 & 2,6 & 3 & 4,1 & 0 & & 2 & 3,2 & 1 & 4,8 & 11 \\
\hline Total & 196 & 100 & 73 & 100 & 29 & 100 & 62 & 100 & 21 & 100 & 381 \\
\hline
\end{tabular}

Fonte: Plataforma Lattes.

Elaboração própria.

Destaca-se, a partir da tabela acima, que a trajetória mais frequente em todas as regiões geográficas é a mesma - Graduação, Mestrado e Doutorado -, porém, a sua maioria no Sudeste é bem menos significativa que em outras regiões: $28,2 \%$, comparado com $50 \%$ no Sul, $56,7 \%$ no Norte e $56,5 \%$ no Nordeste. É possível formular como hipótese que, pelo fato de a região Sudeste se configurar como o centro do sistema de pesquisa brasileiro, seus critérios para a contratação em suas diferentes instituições acabam por ser progressivamente mais elevados, se comparados às outras regiões, exigindo, cada vez mais, o pós-doutorado como credencial de acesso à profissão científica, seja esse realizado no país ou no exterior.

60 Aqui estão somadas as trajetórias que incluem o pós-doutorado no país: Graduação - Mestrado - Doutorado - Pós-doutorado e Graduação - Doutorado - Pós-doutorado. 


\subsubsection{Padrões de trajetórias geográficas}

Nesta seção discutem-se padrões de trajetória, levando em conta não só a formação, mas a inserção institucional com vínculo empregatício, com destaque para a circulação dos pesquisadores no âmbito do território nacional. O interesse reside na análise da mobilidade dos pesquisadores, no decorrer de sua formação acadêmica e inserção profissional. Na tabela abaixo destacam-se, primeiramente, os padrões geográficos da trajetória dos pesquisadores ${ }^{61}$.

Tabela 29: Padrão de trajetória geográfica dos pesquisadores em genética humana e médica (2016)

\begin{tabular}{lcc|} 
Trajetória & No & $\%$ \\
\hline $\begin{array}{l}\text { Totalmente endogâmica } \\
\text { Graduação e trabalho mesmo }\end{array}$ & 194 & 50,9 \\
$\begin{array}{l}\text { estado, doutorado em outro } \\
\text { Graduação e dout orado mesmo } \\
\text { estado - trabalho em outro }\end{array}$ & 73 & 19,3 \\
$\begin{array}{l}\text { Graduação em um estado, } \\
\text { doutorado e trabal ho em outro }\end{array}$ & 32 & 12,3 \\
$\begin{array}{l}\text { Graduação, doutorado e trabalho } \\
\text { em Estados diferentes }\end{array}$ & 28 & 8,4 \\
$\begin{array}{l}\text { Não se aplica } \\
\text { Total }\end{array}$ & 7 & 7,3 \\
\hline
\end{tabular}

Fonte: Plataforma Lattes.

Elaboração própria.

O dado mais notável da tabela acima é que pouco mais da metade dos pesquisadores em genética humana realizou todos os passos de sua formação e encontrou emprego no mesmo estado da federação, indicando uma baixa mobilidade regional dos pesquisadores.

Outro padrão de trajetória a se destacar é que quase $20 \%$ dos pesquisadores se formaram na graduação em um estado, realizaram o doutorado em outro e retornaram para trabalhar no mesmo estado em que se haviam graduado. É possível considerar, com alguma

61 Na primeira linha ("Totalmente endogâmica”), estão os pesquisadores que realizaram sua formação - no caso, graduação e doutorado - em um mesmo estado da federação e trabalham nesse mesmo estado. A categoria "Não se aplica" foi usada para pesquisadores estrangeiros que trabalham no país, mas que aqui não realizaram nenhuma etapa de sua formação. Os demais pesquisadores estrangeiros que realizaram ao menos o doutorado em instituições brasileiras foram computados nos demais padrões de trajetória. Destaca-se, ainda, que para a construção dessa tabela e análise subsequente não foram utilizados os dados geográficos para o mestrado e para o pós-doutorado, de modo a evitar uma multiplicidade de trajetórias, que esconderia os padrões mais importantes de circulação regional. Além disso, tanto o mestrado como o pós-doutorado não são requisitos essenciais para a carreira de professor-pesquisador nas universidades brasileiras. Na amostra selecionada, quase $20 \%$ dos pesquisadores não fizeram o mestrado e cerca de $40 \%$ não realizaram, até o momento, o pós-doutorado, dificultando, portanto, a padronização desses resultados. 
margem de erro, o local de graduação como local de nascimento dos pesquisadores ${ }^{62}$. Assim, esse padrão de trajetória indica que os pesquisadores buscaram, para o seu doutorado, um programa de pós-graduação em instituição mais central, no que se refere ao sistema nacional de ensino e pesquisa, mas optaram por - ou tiveram incentivos para - retornar ao seu estado natal, no momento de uma inserção profissional permanente. A concentração dos pesquisadores em trajetórias endogâmicas indica que eles evitam se mudar para outras instituições do país quando buscam emprego, tendendo a viver na mesma região em que realizaram a graduação e, muitas vezes, também o doutorado.

Esse dado - o de que os pesquisadores brasileiros em genética humana tendem a buscar emprego próximo às instituições em que obtiveram seus diplomas de bacharelado encontra relação com o campo científico brasileiro como um todo. Em pesquisa realizada com os pesquisadores brasileiros ligados a INCTs, pesquisadores da ciência da computação da UFMG encontraram resultados semelhantes, que indicam baixa mobilidade regional, com $32 \%$ dos pesquisadores realizando doutorado em região diferente daquela que obtiveram seus diplomas de graduação e trabalho (Furtado et al., 2015).

Ao olhar para os pesquisadores distribuídos nas cinco regiões do país, é possível encontrar, no entanto, variações nessa tendência nacional geral.

Tabela 30: Padrão de trajetória geográfica por região (2016)

\begin{tabular}{|c|c|c|c|c|c|c|c|c|c|c|}
\hline & Centro-Oeste & $\%$ & Norte & $\%$ & Nordeste & $\%$ & Sul & $\%$ & Sudeste & $\%$ \\
\hline Totalmente endogâmica & 2 & 9,5 & 10 & 34,5 & 10 & 16,1 & 43 & 58,9 & 129 & 65,8 \\
\hline $\begin{array}{l}\text { Graduação e trabalho no } \\
\text { mesmo estado, doutorado } \\
\text { em outro }\end{array}$ & 1 & 4,8 & 10 & 34,5 & 27 & 43,5 & 17 & 23,3 & 18 & 9,2 \\
\hline $\begin{array}{l}\text { Graduação e doutorado no } \\
\text { mesmo estado - trabalho } \\
\text { em outro }\end{array}$ & 9 & 42,8 & 5 & 17,2 & 11 & 17,7 & 10 & 13,7 & 12 & 6,1 \\
\hline $\begin{array}{c}\text { Graduação em um estado, } \\
\text { doutorado e trabalho em } \\
\text { outro }\end{array}$ & 3 & 14,3 & 1 & 3,5 & 1 & 1,6 & 2 & 2,7 & 25 & 12,8 \\
\hline $\begin{array}{c}\text { Graduação, doutorado e } \\
\text { trabalho em Estados } \\
\text { diferentes }\end{array}$ & 6 & 28,6 & 2 & 6,8 & 12 & 19,5 & 1 & 1,4 & 7 & 3,6 \\
\hline Não se aplica & 0 & & 1 & 3,5 & 1 & 1,6 & 0 & & 5 & 2,5 \\
\hline Total & 21 & 100 & 29 & 100 & 62 & 100 & 73 & 100 & 196 & 100 \\
\hline
\end{tabular}

Fonte: Plataforma Lattes.

Elaboração própria.

$\overline{62}$ E, mesmo que não o seja, ainda assim isso em nada invalida o padrão encontrado, isto é, que o local em que é realizada a graduação predomina como o local de fixação do pesquisador na sua carreira acadêmica, ou seja, que esse momento formativo desempenha papel central nesse sentido. 
Pela tabela acima é possível perceber que a região Sudeste é a mais endogâmica, com $65,8 \%$ dos seus pesquisadores realizando todas as etapas da formação e encontrando emprego na mesma região geográfica. É interessante destacar, também, que ao se olhar apenas para o estado de São Paulo, a proporção aumenta ainda mais, com $74 \%$ dos pesquisadores tendo um tipo de trajetória completamente endogâmica. Enquanto isso, Minas Gerais é o estado do Sudeste menos endogâmico, com $56,4 \%$ de seus pesquisadores nessa situação.

No segundo padrão de trajetória geográfica da tabela, aquele que indica o número de pesquisadores que buscaram a formação doutoral em estado diferente daquele no qual realizaram a graduação, e em que posteriormente conseguiram emprego, é preciso fazer uma ressalva. No caso de pesquisadores do Sudeste, esse "outro estado" é, na sua maior parte, constituído por instituições estrangeiras de ensino e pesquisa. No caso do estado de São Paulo, os seis pesquisadores que compõem esse perfil de trajetória realizaram seu doutorado em instituições da América do Norte e Europa ${ }^{63}$.

Destaca-se, também, que o centro do sistema de ensino e pesquisa, a região Sudeste, exporta pouco a sua mão de obra formada localmente para outros estados e regiões, sendo que apenas 5,5\% daqueles que obtiveram o diploma de bacharelado e doutorado nos estados que compõem o Sudeste estão atualmente trabalhando em estados diferentes.

$\mathrm{O}$ dado de $12,8 \%$ de pesquisadores do Sudeste que realizaram graduação em um estado, e encontraram emprego no mesmo estado em que realizaram o doutorado, indica uma baixa absorção dos talentos advindos de outras regiões por parte do centro do sistema de ensino e pesquisa, ainda que esse número não seja irrelevante. Nesse padrão de trajetória, trata-se de pesquisadores que fizeram graduação em outro estado - considerado aqui, de forma aproximada, como local de nascimento - e foram em busca de formação doutoral em instituições mais consagradas, ainda que isso significasse ter de mudar de Estado para tal. Os dados levantados indicam que esses pesquisadores não são, via de regra, absorvidos pelas instituições que os recebem, embora não seja possível afirmá-lo de modo categórico, pois é possível que tais pesquisadores tenham o desejo de retornar aos seus estados de nascimento e não tenham interesse de permanecer na região em que realizaram o doutorado.

É nesse sentido que se deve compreender a trajetória mais frequente nas regiões Norte e Nordeste, aquela em que a formação doutoral é realizada em estado diferente da graduação e do emprego. São estados que têm instituições de ensino superior e programas de pós-

63 São elas: McGill University (Canadá), University of California System, Johns Hopkins University e Medical College of Wisconsin (EUA), Ludwig-Maximilians-Universität München (Alemanha) e University of London (Inglaterra). 
graduação mais recentes - salvo exceções como a UFBA e a UFPA - e não teriam condições de manterem uma endogenia de grau semelhante aos estados que compõem a região Sudeste. Nesse sentido, constata-se que 34,5\% dos pesquisadores da região Norte e $43,5 \%$ dos pesquisadores do Nordeste obtiveram seu doutorado em estados diferentes daqueles em que realizaram a graduação e encontraram trabalho. A região Norte, por sua vez, é proporcionalmente mais endogâmica que a região Nordeste.

Nesse caso, falar em região Norte de forma abstrata pode apagar o fato de que nela, como visto mais acima, a maior parte dos pesquisadores da amostra se localiza em uma mesma instituição, a UFPA. Nas outras instituições do Norte, o padrão mais frequente é o de atrair profissionais que não realizaram nenhuma parte de sua formação no estado, com pesquisadores vindos com frequência do Sudeste e da própria UFPA. Nesse caso, torna-se difícil dizer, com certeza, se esses pesquisadores são, de fato, do Sudeste ou se eles são da própria região Norte e se deslocaram para realizar sua formação ainda na graduação: há poucos dados globais sobre a migração interna brasileira no que diz respeito ao ensino superior, de modo a poder discutir essa questão com mais propriedade. Pode tanto se tratar de pesquisadores do Sudeste que não obtiveram vínculo empregatício permanente em sua região de origem e optaram por migrar, quanto da dinâmica de busca de formação em direção ao centro do sistema de ensino e pesquisa.

Na região Centro-Oeste, a trajetória mais comum é daqueles formados integralmente em outro estado, particularmente no estado de Goiás, em que todos os pesquisadores realizaram sua formação inteiramente em instituições do Sudeste, e no estado do Mato Grosso, em que todos os pesquisadores realizaram ao menos o doutorado em instituições do Sudeste. No Distrito Federal, as trajetórias estão igualmente divididas, com exceção daquela mais comum nas regiões Norte e Nordeste, em que não há nenhum caso. Evidentemente, essas constatações devem ser lidas com cautela, devido ao baixo número de pesquisadores do Centro-Oeste na amostra aqui considerada.

Por fim, destaca-se que a região Sul, assim como a Sudeste, é bastante endogâmica, com 58,9\% de seus pesquisadores nessa situação. Quando se olha apenas para o estado do Rio Grande do Sul, a tendência acentua-se ainda mais, com 75\% dos pesquisadores sem mudar de estado em nenhum momento de sua trajetória. No Paraná esse número diminui para 50\%, mas, ainda assim, constitui a trajetória mais frequente no estado.

A segunda trajetória mais comum na região Sul, seguindo distribuição similar à da região Sudeste, é aquela em que a graduação e o trabalho formal se localizam em um mesmo 
estado, e o doutorado em outro estado. Nesse caso, quatro dos pesquisadores realizaram o doutorado em outro estado da própria região Sul, 7 deles realizaram o doutorado no Sudeste, e 6 em instituições no exterior ${ }^{64}$. Destaca-se, também, a baixa absorção de pesquisadores vindos de outros estados ou regiões, totalizando apenas $2,7 \%$ da amostra regional.

Os dados sobre os diferentes padrões de trajetória institucional e regional indicam o quanto a "periferia" do sistema científico mundial não se configura como espaço homogêneo de produção de conhecimentos, mas, antes, como conjunto de organizações segmentadas e hierarquizadas e em potencial tensão, sendo possível encontrar distinções semelhantes no interior de uma região, de um país e mesmo de uma instituição.

Busquei, nas páginas que antecederam, discutir as principais características dos pesquisadores que compõem o campo da genética humana e médica no Brasil. Partiu-se de dados mais gerais, como distribuição geográfica e por sexo, passando por diferentes características da formação - incluindo-se suas dimensões nacionais e internacionais -, terminando com uma discussão sobre as diferentes trajetórias formativas e de mobilidade geográfica. Essas informações permitiram elaborar um panorama do campo científico escolhido como objeto desta pesquisa e avançar na sua compreensão.

$\mathrm{Na}$ Introdução discuti a proposta de Medina (2013) para a análise dos campos científicos periféricos, que, segundo ele, apresentam condições de entrada mais flexíveis, um número reduzido de atores, e raramente muito especializados. Ao contrário do que ele verificou, para a ciência política, o campo brasileiro da genética humana e médica tem condições de entrada bem regulamentadas, por mais que a exigência do doutorado seja mais recente e, como visto, alguns pesquisadores da amostra tenham encontrado trabalho antes de se doutorarem. Ainda assim, uma marca de que o doutorado - e progressivamente o pósdoutorado - se tornaram condição fundamental para a participação no campo é o fato de todos que alcançaram a inserção profisssional prévia ao doutorado, posteriormente obtiveram essa titulação. Quanto ao número de participantes do campo, embora ele não seja necessariamente pequeno, as disparidades regionais são notáveis. Algumas instituições, notadamente no Sul e Sudeste, têm uma quantidade de pesquisadores que permite formar grupos de pesquisa em genética humana e médica, enquanto a maioria das outras instituições conta tão somente com pesquisadores isolados, em departamentos de biologia pouco especializados.

Discutindo o caso da bioinformática no Brasil, disciplina crucial para a viabilização da pesquisa genômica, Bicudo (2016) mostra duas fases principais. A primeira, de 1997-2006, 
que se deu a partir dos projetos iniciais, como é o do Projeto Genoma Fapesp, e acarretou uma grande concentração geográfica no Sul e Sudeste brasileiro, principalmente nos estados de São Paulo, Minas Gerais e Rio Grande do Sul. A segunda fase, de 2007 a 2014, que tem como característica a dispersão geográfica, refletindo as escolhas tomadas pelo governo brasileiro, que criou instituições de ensino superior, especialmente no interior, em cidades antes sem universidades, e as decisões dos próprios cientistas. Nesse sentido, Bicudo (2016) descreve um desenvolvimento que se inicia pela concentração, mas cuja difusão marcou o desenvolvimento recente da genômica e bioinformática no país. Ainda que a bioinformática esteja presente na genética humana e médica, pensadas enquanto disciplinas, não são a mesma coisa. Dependendo dos mesmos equipamentos e financiamentos, é possível afirmar que um movimento semelhante ao que descreve Bicudo (2016), para a bioinformática, pode ser constatado na área aqui estudada. No segundo capítulo desta tese retoma-se com mais detalhes, a partir da percepção dos entrevistados, as questões relativas ao número de pesquisadores do campo e à falta de especialização nele existente.

$\mathrm{Na}$ próxima e última seção deste capítulo, discuto uma característica marcante e distintiva da área da genética humana e médica. Ao contrário de outros ramos da genética, essa área se desenvolveu aproximando fortemente a genética da medicina, e essas relações precisam ser melhor compreendidas.

\subsection{Genética humana e médica - uma área híbrida}

O objetivo desta seção é discutir a relação entre a genética e a medicina - que se expressa no próprio nome da área estudada, genética humana e médica -, e, como desdobramento, a relação entre a atividade de pesquisa e o atendimento de pacientes com enfermidades genéticas. Para tanto, são utilizadas as entrevistas realizadas com pesquisadores na USP, Unicamp, UFRGS e UFPA, bem como alguns documentos históricos, já tratados na seção destinada à análise do processo de institucionalização da genética no Brasil.

Como dito anteriormente, a primeira geração da genética humana e médica brasileira foi constituída majoritariamente por pesquisadores oriundos do estudo de drosófilas, discípulos de Dreyfus e Dobzhansky, formados, em sua maioria, em cursos de história natural. $\mathrm{Na}$ transição para a pesquisa em genética humana e médica, houve uma forte articulação entre a pesquisa e o aconselhamento genético ${ }^{65}$, criada pelos pioneiros da genética na década de

65 Segundo Décio Brunoni, geneticista ligado ao Departamento de Morfologia da Unifesp, uma das definições correntemente aceitas de aconselhamento genético é a dada pela American Society of Human Genetics: "trata-se do processo de comunicação que lida com problemas humanos associados com a ocorrência, ou risco de ocorrência, de uma doença genética em uma família, envolvendo a participação de uma ou mais 
1950, de modo a viabilizar a pesquisa de doenças genéticas (Ferreira, 2013), sendo que o primeiro serviço desse tipo foi criado por Newton Freire-Maia, na UFPR.

A genética do Brasil se desenvolve basicamente a partir da drosófila, da genética não-médica, e aí chegou um momento em que havia uma demanda grande por aconselhamento genético, as famílias que tinham problemas de doenças hereditárias não tinham a quem se dirigir para receber esclarecimentos. Logo que eu voltei dos Estados Unidos, e logo que o Newton Freire-Maia voltou, também, a gente montou, nos dois lugares, serviços de aconselhamento genético. Então, embora eu não fosse médico, nem o Newton, a gente procurou associações com médicos, e forneceu esse tipo de esclarecimento durante bastante tempo (Joaquim, biólogo, UFRGS).

A relação entre a genética e a medicina existe desde a constituição da área no Brasil, com pesquisas em genética sendo feitas em Faculdades de Medicina - como é o caso de Pedro Saldanha, formado em história natural - e médicos fazendo pesquisa nas faculdades de história natural/biologia - como é o caso de Oswaldo Frota-Pessoa. Relatando o processo de institucionalização da genética do país, uma pesquisadora da Unicamp, envolvida com atendimento de pacientes, afirma:

Como as coisas funcionavam na genética no Brasil? Tem muito a ver com o histórico da especialidade, não só no Brasil, mas no mundo. Onde a genética nasceu? Quando ela surgiu como especialidade médica? Foi no finalzinho da década de 1950. Em 1958 descobriu-se o número exato de cromossomos na espécie humana; depois teve a primeira condição associada a uma alteração genética identificada, que foi a síndrome de Down (...). E muitas dessas pesquisas com a parte cromossômica aconteciam nos institutos de biologia. Então havia alguns médicos que se formaram em outras áreas, mas que se voltaram para a genética por conta de tudo que foi identificado naquele período, e muitas pessoas que trabalhavam nos institutos de biologia da época, inclusive muitos biólogos, que acabaram se envolvendo com a genética, e são geneticistas, de fato, e às vezes até atuando de uma maneira mais clínica, pela falta de médicos para atuar nessa área. Isso meio que aconteceu no mundo todo. E existem aqueles indivíduos que se formaram médicos, e fizeram residência em genética, então tiveram sua formação toda nessa área, principalmente depois dos meados da década de 1980 e 1990, porque antes só havia a residência de Ribeirão Preto, que começou na década de 1980 (Beatriz, médica, Unicamp).

A partir dessas falas, é possível afirmar que o desenvolvimento da pesquisa em genética humana e médica é anterior à consolidação da genética clínica como especialidade médica e foi, de início, levada a cabo por biólogos, de um lado, e médicos com formação em

pessoas treinadas para ajudar o indivíduo ou sua família a: 1) compreender os fatos médicos, incluindo o diagnóstico, provável curso da doença e as condutas disponíveis; 2) apreciar o modo como a hereditariedade contribui para a doença e o risco de recorrência para parentes específicos; 3) entender as alternativas para lidar com o risco de recorrência; 4) escolher o curso de ação que pareça apropriado em virtude do seu risco, objetivos familiares, padrões éticos e religiosos, atuando de acordo com essa decisão; 5) ajustar-se, da melhor maneira possível, à situação imposta pela ocorrência do distúrbio na família, bem como à perspectiva de recorrência do mesmo" (Brunoni, 2002, p. 101). 
outras especialidades, de outro. Como dito na introdução, no Brasil, a primeira residência em genética clínica foi criada em 1977, no Hospital das Clínicas, ligado à USP de Ribeirão Preto (Emerick; Montenegro \& Degrave, 2007) e seu reconhecimento como especialidade médica pelo Conselho Federal de Medicina ocorreu apenas em 1983.

Nesse contexto, a relação entre a "assistência"66 e a pesquisa é uma característica marcante do início da pesquisa em genética médica, e persiste até o presente, embora não necessariamente organizada da mesma maneira e tendo as mesmas finalidades. O objetivo aqui é então retraçar, a partir dos depoimentos coletados, as relações entre a pesquisa e a assistência, no contexto de trabalho dos entrevistados. A percepção dessa relação varia significativamente de acordo com as características dos entrevistados e o tipo de pesquisa que realizam. Por exemplo, entre entrevistados formados em medicina - com residência em genética clínica ou não -, quando se fala dessa relação, é comum o destaque à assistência:

Nós aqui estamos pra dar aula, fazer assistência, e fazer pesquisa. (...). Mas a minha pesquisa não é pesquisa básica, minha pesquisa é aplicada, eu sou médico. (...) Eu acho que a pesquisa é subproduto - e o ensino também - da assistência médica. Em pesquisa e ensino, a assistência, para o médico, é o essencial. Se você não tiver uma boa assistência, não vai ter material para pesquisa e para o ensino. O que vou ensinar para os alunos de medicina? Tenho que mostrar pra eles como é o diagnóstico, ensinar como se examina uma criança do ponto de vista genético (Tiago, médico, USP/RP).

O trabalho que eu faço com as populações [indígenas] é como se a pesquisa fosse um subproduto da atenção que eu tenho com eles. Se eu faço atendimento a uma população, a pesquisa vai ser o subproduto daquela atenção. (...) eu faço os exames de laboratório lá na aldeia, vejo o nível de glicose, colesterol, faço hemograma, vejo se tem anemia ou não... É extensão. E a pesquisa é como um subproduto disso, então as coisas estão juntas (Matheus, médico, UFPA).

Nessas falas, a pesquisa aparece como algo que de certa forma é uma consequência do atendimento de pacientes, tido como mais central, em que as questões a serem pesquisadas vão aparecendo a partir desse contato. Essa relação entre atendimento e definição do que seria uma agenda de pesquisa aparece de forma ainda mais marcante na fala de uma médica geneticista, contando um pouco de sua experiência no mestrado e doutorado:

A minha prática, e creio eu que a de todos nós aqui - eu digo nós, os mais velhos - começa com o fato de que a gente é incorporado ao staff, nós fizemos parte do quadro de trabalho para fazer assistência dentro desse hospital. Assistência de uma especialidade que não existia muito nitidamente, não era nada tradicional, e que atende doença rara. Hoje em dia doença rara está na moda, a portaria 199 é de 2014. E eu estou falando de 1987, quando não tinha portaria, mas as doenças raras existiam, e eram ainda

66 "Assistência" foi o termo mais utilizados pelos pesquisadores entrevistados para descrever o atendimento aos pacientes no contexto dos serviços de genética médica. 
mais raras, porque ninguém estava diagnosticando elas. (...) então cada doente que aparecia era quase um território a ser desbravado, é como se a gente estivesse fazendo relatos de caso, case reports, anedoctal reports, toda semana. Claro que à medida que a gente começou a ver e ver e ver, a gente identificou as mais comuns ao nosso redor. (...) E era natural que a gente, à medida que visse 2, 3, 4, 5 casos semelhantes, começasse a pensar "o que é isso? É um efeito fundador? (...)". A pesquisa em medicina sempre é uma pesquisa traduzida, pretende traduzir algum resultado para a assistência; a pesquisa básica, aberta, só na básica mesmo, quando a gente está em área clínica não é. Porque o que nos move é tentar reduzir o sofrimento, tentar descobrir um tratamento. E como a assistência influencia? Primeiro ela vai influenciar como nesse exemplo que eu te dei, do meu assunto de doutorado, $\mathrm{o}$ assunto era doença [1], e de repente não era mais, porque a realidade se impõe, o que é frequente se impõe [mudou para doença 2]. Então é importante a gente saber o que tem na assistência, porque aquilo ali acaba dando a escala de prioridades (Ana, médica, UFRGS).

$\mathrm{Na}$ descrição acima é possível visualizar como o que aparece no atendimento a pacientes, no serviço de genética médica de um hospital, acaba por se impor no momento de formular as questões de pesquisa pertinentes, nesse caso, um doutorado. O outro destaque importante, nessa relação entre a assistência e pesquisa presente nas falas de alguns entrevistados, é a definição das pesquisas nesses moldes como sendo "aplicadas". Uma pesquisadora da Unicamp, também médica, define sua pesquisa de modo semelhante:

Pensando que eu sou médica e pensando na genética baseado em quem faz medicina, a pesquisa vem muito da prática. $\mathrm{O}$ fato de você ter atendido um número $\mathrm{X}$ de pacientes com determinada doença te faz pensar em coisas que você poderia contribuir, na etiologia, no tratamento, no suporte desses indivíduos, no aconselhamento genético. Isso, acho, é o mais clássico em termos de atendimento e de pesquisa em genética, no Brasil. Você acaba reunindo um grupo de pacientes e a partir dali vai estudar. Também tem quem faça pesquisa básica, não é o meu caso, eu faço pesquisa aplicada. Então tem gente que pode fazer genética só no laboratório, mas em genética médica, normalmente, ele tem algum acesso a material de paciente, embora não atenda, ou às vezes tem pesquisa de células-tronco ou mutagênese, alguma coisa que é só a partir de célula, mesmo. Mas, em geral, em termos de genética médica, a maioria depende de atendimento de pacientes ou de algum contato com paciente. Desenvolvi minha carreira focada no paciente, mas não necessariamente em atendimento direto; eu busquei estratégias que juntassem um número maior de pesquisadores para trabalhar dentro do mesmo assunto, e com realidades diferentes, então são enfoques diferentes, mas, o dado primário é de pacientes, sempre (Gabriela, médica, Unicamp).

A genética médica enquanto atividade científica é caracterizada, nessas falas, como uma pesquisa na maior parte das vezes "aplicada", que vem da "prática", ou seja, é elaborada no contexto da assistência, que pode fornecer, inclusive, as prioridades em termos de temas e abordagens. No último trecho citado, fica marcante uma outra dimensão, que é o acesso ao “material de pacientes" como condição para a realização desse tipo de pesquisa, ainda que não 
seja necessário, como foi apontado pela pesquisadora, um contato direto para a viabilização da investigação. Tal configuração não é descrita apenas pelos médicos geneticistas, mas também por biólogos trabalhando com genética médica, como por exemplo:

Então a gente tenta vasculhar o câncer e ver o que acontece nele, para usar esse achado para beneficiar o paciente diretamente. A nossa preocupação aqui, o raciocínio, a gente parte daí: "qual é o problema do paciente?", "olha, acontece isso", "então vamos ver o que está levando a isso, ou porque aconteceu isso". A gente vai meio que nessa linha (Samuel, biólogo, UFPA).

Ainda que o pesquisador em questão seja formado em biologia, ele descreve o processo de definição das questões de pesquisa a partir das necessidades da assistência ao paciente de forma semelhante a dos médicos entrevistados. Em outros termos, ter como ponto de partida - e objetivo - a assistência, não é característica exclusiva dos médicos entrevistados. Essa conexão fica mais clara no exemplo a seguir, que marca também o caráter "aplicado" da pesquisa que realiza:

Acho que no geral é uma pesquisa muito aplicada. Mesmo que ela no papel não seja aplicada, na minha cabeça eu já tenho a aplicação dela. A gente tem um contato muito bom com os pacientes, então pelo menos uma vez por ano, a gente se reúne com todos os pacientes. Vou te dar um exemplo de como surgiu um projeto: veio uma paciente e disse "eu estou recebendo um tratamento - é um tratamento caro, o tratamento deles é muito caro - e eu tive que entrar na justiça para conseguir o dinheiro para o tratamento". Ela conseguiu o tratamento, veio por três meses, aí parou, não veio mais, ficou um tempo sem vir, depois voltou. Ela disse "me sinto mais cansada, a primeira coisa que eu sinto quando paro o tratamento é que eu fico cansada". Eu disse "pode ter uma alteração aí". Então eu peguei os animais, dei os tratamentos para os animais, parei, voltei a tratar, para ver se melhora tudo como era antes. $\mathrm{O}$ trabalho foi esse. $\mathrm{E}$ o que a gente viu foi que algumas coisas realmente pioram e não voltam (...). Então a gente pega as informações a partir dos pacientes para tentar trazer para o nosso dia a dia de laboratório, ver o que a gente pode pesquisar que vai, de alguma forma, ter alguma aplicação para eles no futuro (Gustavo, biólogo, UFRGS).

Se no exemplo acima o projeto de pesquisa está ligado ao tratamento de uma determinada doença genética, a articulação que mais apareceu nas entrevistas foi a da relação entre o diagnóstico de um paciente com uma determinada síndrome genética, e a elaboração de pesquisas e artigos discutindo essa síndrome, tal como pode ser verificado na fala abaixo:

No início dos anos 1990, foi formado um grupo de estudos dos distúrbios da diferenciação do sexo (...). A gente trabalha em conjunto, faz a avaliação dos possíveis diagnósticos para aqueles indivíduos, e a gente estuda a parte molecular para a confirmação do diagnóstico, para ver se aquela causa genética realmente explica o fenótipo do paciente. (...) A gente vê um grupo de pacientes que tenham mais ou menos as mesmas características, e nesse grupo a gente vai buscar um determinado gene que seja candidato para que tenha alguma mutação, alguma alteração, e que seja por causa disso que eles 
estão apresentando aquele fenótipo. Fazemos esse tipo de trabalho. E dele decorre todas as outras propostas de pesquisa, a partir da nossa curiosidade: achou uma mutação, "ah, o que ela está fazendo naquela molécula?", "ah, ela muda a estrutura da molécula, aí a proteína não tem mais capacidade de se ligar não sei aonde", ou "não tem a capacidade de fazer a atividade enzimática que ela deveria". Vamos buscando a partir do paciente, a mutação, e a partir dessa mutação a gente vai buscar a ciência, a causa daquela falha que está causando a doença. (...). As novas ideias surgem dos novos pacientes, dos casos que ainda não foram resolvidos. A gente tem uma casuística bastante grande, temos uns 500,600, pacientes já estudados, e muitos ainda estão a esclarecer (Manuela, bióloga, Unicamp).

A gente vive de amostras de pacientes e a gente trabalha sobre elas, encontra as alterações e estuda essas alterações (Sara, bióloga, Unicamp).

Como as "amostras de pacientes" são cruciais para essa articulação entre diagnóstico e pesquisa, a colaboração com médicos aparece como fundamental para a viabilização e o bom desenvolvimento da pesquisa, nas falas de alguns entrevistados formados em biologia e áreas correlatas, como biomedicina.

Eu não teria condições de estudar [determinada doença] sem um psiquiatra do meu lado, que entende da doença. Eu posso entender do DNA, de como as coisas se processam, explicar porque tal gene pode ser importante, mas a visão clínica dele é extremamente importante para aquilo fazer sentido. E é diferente do pessoal (...) que está muito focado nas doenças genéticas clássicas, esses talvez precisem menos de colaborações de clínicos, mas se a gente vai para essas áreas de doenças multifatoriais é imprescindível essa colaboração. Eles têm menos essa necessidade que eu tenho, porque trabalho com essas doenças multifatoriais, de ter essa interação importante com os médicos. Mas mesmo pensando nas doenças mendelianas, como é que esses pacientes chegam? São mandados por clínicos (Débora, bióloga, UFRGS).

Essa colaboração com médicos geralmente é buscada pelos pesquisadores, e como destaca uma delas, não se trata de uma relação institucionalizada, mas muitas vezes de um contato direto, ou mesmo "pessoal".

Eu trabalho investigando a função de genes que a gente especula que tenham participação na leucemia, então, com isso, eu faço toda uma pesquisa em linhagens celulares, em modelo animal, de pesquisa básica, que independe de material de paciente. (...). E tem análises que eu faço em amostras de pacientes. Eu tinha acesso muito grande quando eu estava como pós-doc no hemocentro, porque ali eu estava inserida em um grupo em que a pesquisadora tinha todo esse cuidado, a médica que era chefe do laboratório, a minha supervisora, tinha todo o ambulatório, que tinha uma organização e que recolhia esses materiais. Então eu tenho acesso a esses materiais por questão de conexão, de ter os contatos. (...) eu tenho esse contato pessoal, se eu não tivesse eu teria que ir lá, bater na porta dela e pedir o que eu preciso. E aí depende da abertura que cada pesquisador tem... Como eu disse, não é uma coisa institucionalizada: olha, a gente tem esse banco, os pesquisadores têm acesso a esse banco (Isabela, bióloga, USP/RP). 
A pouca institucionalização desse tipo de colaboração - e sua necessidade prática para alguns biólogos entrevistados, que dependem das "amostras de pacientes" - pode produzir algumas tensões:

Acho que não há como fazer genética médica sem colaboração, porque a gente não tem condições de acessar todas as nossas perguntas sem auxílio. Por exemplo, eu que sou biomédica, eu não tenho como acessar os meus pacientes, os pacientes que vão entrar na minha pesquisa, sem as médicas; então se eu não fizer colaboração com elas, isso não vai existir. (...) Apesar das dificuldades disso, apesar de que as pessoas acham que só porque tem a amostra de uma determinada doença no freezer ela é dona dessa amostra. Apesar de as vezes ser difícil, eu acho que a colaboração é fundamental em qualquer campo da ciência (Monique, bióloga, UFPA).

Acima, é possível identificar uma certa dificuldade de convencer pessoas a colaborar, ainda mais quando se está no início da carreira, sem muito a oferecer em troca de amostras de uma determinada doença. Ao que tudo indica, a moeda de troca nesses casos pode ser a própria publicação, o que também causa certo desconforto:

Não é incomum algum médico me mandar paciente para estudar e querer o nome dele no artigo. Mas ele não fez nada, ele mandou o sangue para mim. E muitas vezes a gente tem que ceder a isso. Isso não é correto. Isso está acabando, as revistas têm perguntado o que exatamente cada um fez no artigo (Sara, bióloga, Unicamp).

Há, nesses relatos, evidências de certa relação assimétrica: como se trata de uma pesquisa que depende de amostras, um pesquisador formado em biologia, sem um contato estabelecido ou "institucionalizado" com médicos, pode precisar "ceder" a pressões e colocar como autor do artigo alguém que, do seu ponto de vista, não cumpre os requisitos necessários para fazer parte da autoria. Outra entrevista evidencia essa mesma relação assimétrica, com mais veemência:

[No doutorado] eu tinha que fazer plantão no hospital [para coletar material para pesquisa]. A minha formação é biologia, não medicina, e eu estava acostumada a trabalhar em laboratório. Sou bióloga por opção - isso é uma coisa que os biólogos sofrem um pouquinho, principalmente os biólogosque estudam biologia humana, um certo preconceito: "por que vocês não vão fazer medicina?". A gente não quer fazer medicina. Acham que a gente faz biologia porque não tem a capacidade de passar no vestibular de medicina. $\mathrm{E}$ minha opção é ser bióloga, estou priorizando a pesquisa, não o atendimento clínico (Camila, bióloga, UFRGS).

Essas tensões, embora presentes em poucas entrevistas, foram descritas com algum constrangimento por aqueles que as mencionaram, evidenciando ser de alguma forma um assunto tabu, o que indica, também, que a pouca frequência em que é mencionado não é indicativo de sua pouca frequência nas colaborações. O fato de que ao final de uma das 
entrevistas em que o tema foi discutido com mais veemência, me foi solicitado que se suprimisse essa parte da conversa da transcrição fortalece o indício de que essa tensão é mais comum do que as entrevistas deixam entrever.

Discutindo se a pesquisa em genética humana e médica pode ser realizada por biólogos, um pesquisador formado em medicina - mas que explicita não se identificar como "médico", afirma:

Se o sujeito é biólogo, e está numa instituição que não é da área médica, como é que ele vai poder coletar o material pra estudar? Eventualmente ele pode obter material humano a partir de uma colaboração, mas uma enorme parte do trabalho será impossível num instituto que não tenha uma área médica em desenvolvimento, como uma faculdade de medicina ou um hospital. Se ele for um biólogo dentro de uma instituição desse tipo, não vejo diferença alguma, o que importa é a hipótese que ele fez. Ele não precisa ser um médico atendente. Aliás, um médico atendente se divide em dois, na minha opinião, quando ele resolve fazer pesquisa, porque uma coisa é ele atender o paciente e resolver qual deles vai ser parte de uma pesquisa, e a outra é fazer as análises. Ele tem que ser dois: na hora que ele está no laboratório ele é um, na hora que ele está no ambulatório ele é outro. Eu costumo dizer aos alunos (...): "a grande diferença entre um médico e um biólogo é que o biólogo é treinado a fazer perguntas, e o médico é treinado a dar respostas" (Vinícius, médico, USP/RP).

Além de discutir a necessidade que biólogos têm de fazer colaborações para obter o "material" da pesquisa, enuncia-se um outro tipo de tensão, essa não mais relativa a um biólogo fazendo pesquisa em genética, mas às dificuldades que um médico que atende pacientes pode ter. Alguns pesquisadores, médicos, inclusive relataram certas dificuldades em realizar a sua pesquisa, no contexto de uma faculdade de medicina:

Aqui sempre teve, também por conta do meu orientador, ele sempre deu muito valor à atividade clínica associada com a atividade de laboratório, com a mão na massa. Isso é diferente de outras áreas clínicas. Eu sempre brinco que aqui a gente é muito médico para o departamento, e muito biólogo para $o$ hospital. Mas, na verdade, a gente tem uma frequência de laboratório muito maior [do que outras áreas clínicas]. Então, mesmo na residência, se passa pelo laboratório de citogenética, vai lá lavar a lâmina, no mestrado passa um tempo no laboratório... Ribeirão tem um pouco essa cultura, né? $\mathrm{O}$ médico vai para o laboratório com mais facilidade que em outros lugares (Artur, médico, USP/RP).

Aqui [na USP de Ribeirão Preto] eu me sentia seguro, eu sabia que as pessoas valorizavam esse tipo de ciência. Por que na época [final dos anos 1990], médico mexendo com camundongo era um negócio quase meio ofensivo (Diego, médico, USP/RP).

Destaca-se uma ambivalência dos pesquisadores em genética médica, que, de um lado, podem ser considerados como não fazendo pesquisa séria, serem "muito médico para o 
departamento" e, de outro, não serem identificados como verdadeiros médicos atendentes pelos seus colegas de profissão. Está subentendida aqui uma visão de que médicos não fariam pesquisa, o que é questionado pelos entrevistados médicos, de uma forma geral. Tal tensão fica ainda mais evidente na fala abaixo:

\begin{abstract}
Quais são as especificidades de ser um geneticista clínico, em termos de pesquisa?

Primeiro que você se apropria de uma das ferramentas, que é o exame clínico (...), você tem um arsenal, pela formação, que o outro profissional não tem. Eu acho que não impede, na pesquisa, você conseguir fazer uma coisa boa não sendo médico. Por exemplo, esse meu aluno é biólogo, mas eu sempre tento fazer os meus alunos, independente da formação, participarem do ambulatório, para eles saberem a relevância do que eles estão fazendo, em relação ao material com o qual eles estão trabalhando. É diferente de você abrir uma estufa e tirar uma placa de Petri (...). É mais difícil, você tem que convocar, você tem que conversar com o paciente sobre o termo de consentimento livre e esclarecido... É uma outra dinâmica, o paciente se sente grato em poder ajudar, mas ele espera receber alguma coisa em troca, e você tem uma responsabilidade, de alguma forma, com isso. (...) O que tem de dificuldade é que seu compromisso com o laboratório é mais limitado, você tem que dividir o seu tempo. Mas a pecha de que a gente não sabe fazer laboratório não é verdade (Artur, médico, USP/RP).
\end{abstract}

Além de questionar a visão de que médico "não sabe fazer laboratório", esse trecho da entrevista evidencia que, se de um lado há vantagens, no contexto da pesquisa, em ser um médico que atende pacientes - porque você tem um conhecimento específico, no caso, o exame clínico, além do acesso direto aos pacientes -, de outro, é necessário "dividir o seu tempo", ou "se dividir em dois", para poder realizar as duas atividades. A dificuldade em realizar a pesquisa num contexto de alta carga de atendimento é destacada por uma médica geneticista de Belém:

Quando você está muito envolvida na parte assistencial, você tem mais para publicar, porque você vai ter que dar uma parada, você vai ter que fazer uma atualização de artigos (...). Mas o tempo, quando você está muito envolvida na parte assistencial, que foi a minha trajetória, é pequeno. (...) Mas quando você está envolvida nessa questão do diagnóstico, às vezes você vai buscando aproximação de pessoas que colaboram contigo e que, muitas das vezes, estão muito arraigadas na academia, e isso é uma coisa que te puxa e que te leva (Eduarda, médica, UFPA).

Destaca-se acima outro elemento da colaboração entre médicos e biólogos, em que os últimos, mais identificados pela entrevistada como estando no contexto acadêmico, realizando pesquisa, a estimulam a realizar trabalhos de pesquisa e a publicar artigos.

Observou-se algumas dimensões envolvidas na colaboração entre médicos e biólogos, tanto em elementos considerados como produtivos para a pesquisa, com a ideia de junção de 
expertises ou ferramentas diferentes para responder a questões de pesquisa - e mesmo viabilizar a pesquisa em si -, como em elementos mais conflituosos, que evidenciam tensões que fazem parte desse tipo de trabalho.

Pode-se constatar, aqui, um jogo relacional, permeado de percepções e autopercepções, que são reforçadas e/ou combatidas. Primeiro, a imagem do biólogo que atende paciente, situação que é vista como inadequada por aqueles formados em medicina. Segundo, a percepção, entre biólogos, que alguns os enxergam como tendo status inferior, como se os "biólogos humanos", se pudessem escolher, teriam se tornado médicos. Do outro lado, tem-se a imagem de que médicos não fazem pesquisa, ou que seu tempo precisa ser dividido entre fazer perguntas e dar respostas, o que incomoda aqueles que se veem - e querem ser reconhecidos - como pesquisadores. Por fim, entre aqueles que se identificam como médicos, que atendem pacientes, tem-se igualmente uma reclamação acerca de um status inferior, no interior da medicina, por ser uma especialidade pequena e, em termos relacionais, desvalorizada.

De toda forma, principalmente entre aqueles envolvidos com o diagnóstico de pacientes com doenças genéticas - sejam médicos, sejam biólogos -, a relação entre pesquisa e assistência é marcante, imbricada, e muitas vezes tida como benéfica para ambas. Descrevendo o serviço de genética médica do Hospital de Clínicas de Porto Alegre, um dos pesquisadores entrevistados afirma:

Desde o início, nós optamos por construir o serviço com três pilares: assistência, ensino e pesquisa. Têm muitos projetos de pesquisa em andamento. E o serviço é um jogo de ganha-ganha, porque a pesquisa se desenvolve, faz um projeto, capta recursos, e com isso apoia o diagnóstico, por exemplo, apoia a assistência, porque aí tem o equipamento novo que faz mais exames. E os pacientes que a gente avalia acabam nos dando experiência para poder testar os novos métodos, para poder fazer os diagnósticos de uma maneira correta. E tem a parte de ensino, os alunos de mestrado e doutorado fazendo as pesquisas aqui. Acho que essas três coisas são integradas e funcionam se apoiando umas às outras. Tem um quarto componente que é a parte de extensão. $\mathrm{O}$ que a gente gera aqui dentro de conhecimento, a gente procura estender para a sociedade, ou para a própria comunidade médica de outros lugares do Brasil (Luciano, médico, UFRGS).

Relato similar é feito por um pesquisador - biólogo - da Unicamp, ligado, também, ao atendimento de pacientes:

Queria saber mais sobre a relação entre a assistência e a pesquisa. Em que medida elas se relacionam? Elas se relacionam?

Elas caminham juntas. Porque, na verdade, a assistência que a gente presta aqui é a nossa fonte de casuística para as pesquisas. Como eu te falei, eu trabalho muito com pesquisa aplicada, a gente trabalha com a genética 
humana aplicada, a principal área de pesquisa é a genética médica aplicada à genética clínica. Então os projetos e as publicações envolvem pacientes. Então a nossa fonte de casuística são os pacientes que a gente atende na assistência. E, por outro lado, a assistência é, digamos, melhorada, pela possibilidade de os pacientes poderem participar de projetos de pesquisa. Porque se eles não tivessem a possibilidade de participar de projetos de pesquisa, muitos testes genéticos, muitos exames, que a gente pode fazer via projeto de pequisa, não seriam possíveis via SUS. Então é uma via de duas mãos. A gente encaixa eles nos projetos de pesquisa, consegue casuística para as pesquisas, e por outro lado eles conseguem um diagnóstico que eles não conseguiriam pelo SUS. É o jeito que a gente tem trabalhado há muitos anos (Danilo, biólogo, Unicamp).

Nessa fala, é possível visualizar uma outra dimensão da relação entre pesquisa e atendimento aos pacientes, enunciada por aqueles que estão em contato mais direto com pacientes, geralmente ligados a um hospital: a pesquisa que auxilia - inclusive financeiramente $-\mathrm{o}$ atendimento aos pacientes.

No Brasil a gente praticamente não tem acesso a diagnóstico molecular. Porque é caro, porque o SUS não paga, porque os convênios muitas vezes não pagam. A maneira que muitas pessoas têm de conseguir acesso ao diagnóstico é através de um projeto de pesquisa (Thais, bióloga, UFRGS).

Mas essencialmente é isso, acho que a pesquisa sustenta a investigação clínica e o manejo em doenças raras no Brasil (Artur, médico, USP/RP).

Nas quatro instituições em que foi realizado este trabalho de campo há relatos da importância dos projetos de pesquisa para a manutenção da assistência aos pacientes, seja por meio da compra de equipamentos que podem ser usados para realizar testes melhores ou mais precisos, seja pelo financiamento mesmo desses testes. Um dos pesquisadores entrevistados, de Ribeirão Preto, conta que, para além do financiamento, o fato de o atendimento ser realizado em um contexto de pesquisa - como um hospital universitário - pode trazer benefícios, porque são médicos que também tem interesse em fazer pesquisa, em publicar artigos, o que em parte auxilia na hora de viabilizar exames não cobertos pelo SUS, mesmo que não haja verba de uma pesquisa naquele momento:

Você pode pedir exames moleculares, que via convênio e SUS não pode. A gente tem feito o uso de todos os recursos que a gente tem. Então, a minha pesquisa, como a de outros professores aqui, está muito vinculada ao estudo de casuística. E ao estudar a casuística você sempre passa por uma etapa que é de diagnóstico, e você sempre acaba incorporando uma técnica que auxilia você a esclarecer esses casos, e acaba ajudando a família a se posicionar melhor frente ao problema que ela tem, as suas escolhas reprodutivas ou de metodologias de prevenção. Acho que dentro do serviço universitário, quando a gente considera ele de qualidade, tem que levar isso em consideração, não é o SUS igual ao resto, é o SUS sustentado pela linha de pesquisa, que tem outras pretensões. Um pronto-socorro não quer 
publicar caso, isso não é importante para o profissional que está trabalhando lá, mas é para nós (...), a nossa carreira precisa dessas coisas.

Então vem um paciente, ele precisa de um diagnóstico, e vocês têm mais ferramentas para dar esse diagnóstico porque tem verba de pesquisa....

Não é só verba! A verba também, mas tem a necessidade de se fazer pesquisa dentro da instituição. Quando está financiado, está financiado, mas quando não está a gente tenta dar um jeito, porque a gente considera que isso seja importante (Artur, médico, USP/RP).

Nesse sentido, a necessidade de se fazer pesquisa na instituição universitária - e a vontade de realizá-la - incentiva os médicos inseridos no "SUS sustentado pela linha de pesquisa" a buscar alternativas para a viabilização de diagnósticos e possíveis publicações, a despeito de dificuldades orçamentárias. Nessa mesma temática, uma pesquisadora sênior, falando de seu doutorado, afirma que essa relação entre atendimento e pesquisa é, de certa forma, constitutiva da institucionalização da área no país:

Os ambulatórios foram começando. Existia o ambulatório de pediatria e o de clínica médica, e o departamento de genética, que fazia os exames, e com essa colaboração as coisas iam caminhando. Mas o que acontecia? Muito do que se fazia, e que já seria no contexto de pesquisa, acabava sendo a assistência que nós oferecíamos para os nossos pacientes. Isso foi o que aconteceu aqui: o departamento oferece um rol de exames, mas, na verdade, poucos desses exames são pagos pela SUS (...). Com isso, nos habituamos a dar aquele jeitinho brasileiro, que é usar a pesquisa para poder oferecer assistência de qualidade. E de repente a gente vê que praticamente todo mundo está trabalhando dessa maneira (...). E muitas vezes a gente acabava fazendo os projetos de pesquisa já com esse viés. E, com isso, as instituições de fomento começam a perceber que nós estamos fazendo projetos muito mais para fazer essa pesquisa aplicada e oferecer esses exames do que de fato fazendo pesquisa de ponta (Beatriz, médica, Unicamp).

A partir desses relatos, é possível ver com mais detalhes a relação entre a pesquisa e o atendimento em suas várias dimensões. De um lado, ela é colocada como uma forma de viabilizar a pesquisa, obter "material de pacientes" e também novas ideias, novos temas ou novos caminhos a percorrer, em um contexto descrito como "pesquisa aplicada". De outro, a pesquisa auxilia no atendimento, seja pela formação dos médicos-pesquisadores e seu interesse em se manter atualizado, encontrar novos casos, publicar novos artigos, seja pela obtenção de aparelhos mais sofisticados, pelo avanço e refinamento de métodos diagnósticos, ou pela própria viabilização financeira desse diagnóstico, por meio das verbas de projeto de pesquisa. Por fim, tem-se a ideia de que essa articulação, como explicitado na fala acima, faz com que recorrentemente os projetos de pesquisa funcionem mais para oferecer exames, do que para fazer "pesquisa de ponta". Ao mesmo tempo, tal articulação - ou "jeitinho 
brasileiro" - apesar de ser de longa data, é motivo de crítica por parte de alguns dos entrevistados, porque traz problemas para a pesquisa e, principalmente, para o atendimento:

É uma relação extremamente próxima, e isso traz vantagens e desvantagens. Conseguimos fazer muita coisa em termos de diagnóstico só pela via da pesquisa. Isso é bom e isso é ruim. Por que é bom? Porque de outra maneira os pacientes não teriam acesso ao diagnóstico, essa é uma maneira de introduzir determinados diagnósticos com técnicas complexas, dentro da prática clínica (...). Por outro lado isso é uma coisa ruim. Por quê? Ninguém se mexe para implantar como serviço, como realmente diagnóstico. E não há dúvida que existem determinados padrões de qualidade que você tem que ter quando oferece diagnóstico, e que você não tem que ter quando você oferece pesquisa. Vou te dar um exemplo: quem faz o teste na pesquisa, o trabalho laboratorial, é o aluno, que é uma pessoa em formação; quando você vai para um laboratório de serviço, que fornece isso como diagnóstico, vai ser um técnico, um profissional de nível superior, especificamente treinado para fazer aquilo. É diferente. Quando você tem um aluno, bom, ele vai fazer tudo direitinho, mas você pode ter alunos que são um pouco mais sloppies, não vão fazer a coisa direito. E quando o aluno acaba a tese, quando acaba o financiamento, você para de oferecer aquilo (Sofia, médica, Unicamp).

Com isso nós não temos algo que possa ser considerado justo, equitativo, sempre disponível; porque eu acho perverso você abrir um projeto, vêm as pessoas, tem o diagnóstico, e, de repente, tem aquela outra família que chega e você diz "não, agora não pode mais porque o projeto de pesquisa terminou” (Beatriz, médica, Unicamp).

É possível entrever alguns problemas elencados pelos pesquisadores nessa relação entre atendimento e pesquisa. Primeiro, questões sobre a qualidade desse diagnóstico, feito no contexto da pesquisa: não se trata de um laboratório de análises clínicas, com técnicos especializados e certificados, controle de qualidade e formalização ${ }^{67}$, mas um laboratório de pesquisa, em que os exames são realizados por alunos sem treinamento anterior específico, envolvidos com suas dissertações ou teses. Para além da questão de um "padrão de qualidade", o exame realizado nesses moldes não é perene, muitas vezes será oferecido apenas enquanto durar o projeto de pesquisa, o financiamento daquela pesquisa. Esse oferecimento provisório ${ }^{68}$, ao mesmo tempo, cria uma "expectativa", e os pacientes com suspeita daquela determinada doença continuam sendo encaminhados para o serviço de genética. Por fim, alguns pesquisadores afirmam que há uma certa "acomodação" com esse estado das coisas, que tanto médicos quanto pacientes, ao lançar mão desse "jeitinho

67 Como afirma um dos entrevistados: "se você vai em qualquer laboratório privado, se você muda um celular de lugar, tem que colocar no protocolo: 'mudei de lugar em tal data, calibrei o equipamento de novo'. Agora vai em laboratório de pesquisa, em qualquer lugar, ver se tem isso. Não tem. E 'vende' o exame como se fosse de pesquisa mas também como exame clínico. Acho que a gente está aprendendo muito com isso tudo ainda... (Artur, médico, USP/RP).

68 Há exames disponíveis na rotina do Serviço, cobertos pelo SUS, mas eles são de alcance limitado, e não atendem todas as síndromes genéticas. 
brasileiro", deixem de fazer tanta pressão para de fato inserir os testes mais complexos na rotina de atendimento em genética clínica do SUS, de modo a estar sempre disponível, independente da existência de um projeto de pesquisa.

A motivação para se participar de um projeto de pesquisa não precisa ser o diagnóstico, o indivíduo pode querer participar independente do diagnóstico. Essas coisas não estão claras na cabeça - e eu falo para você - dos médicos, e não estão claras na cabeça dos pacientes. No Brasil existe muita confusão entre o que é assistência e o que é pesquisa. Preferiria trabalhar num ambiente em que essas coisas são separadas (Sofia, médica, Unicamp).

A separação entre a pesquisa e a assistência, considerada acima como algo desejado, que traria mais clareza na relação entre médicos e pacientes, é também defendida por uma pesquisadora de Porto Alegre, ligada ao Hospital de Clínicas:

A assistência, antigamente, e eu acho que em muitos hospitais ainda é assim, era feita quase que no mesmo ambiente da pesquisa. Nesse hospital, até mais ou menos 2010, a gente fazia tudo no mesmo ambulatório, tanto pesquisa quanto assistência. Às vezes na mesma entrevista da assistência tu acabava coletando coisas de pesquisa. Então parecia para nós natural fazer isso, e que seria ruim clivar, dividir, separar, porque ia ser artificial (...). [A partir de 2010 a pesquisa e atendimento passaram a ser feitas inclusive em prédios separados] E aquilo é uma maravilha. É muito melhor dividir, porque dai tu tem objetivos e metas claras, tanto para ti quanto para o paciente (...) A pesquisa feita de forma separada da assistência é muito melhor porque a gente tem mais clareza de metas: hoje eu estou aqui para ouvir os seus problemas, para tentar resolver assistencialmente eles, e hoje não, hoje eu estou aqui para a senhora ouvir o que eu preciso saber da pesquisa; é o contrário, quando a gente faz pesquisa quem está mobilizado, quem pediu para fazer alguma coisa foi o pesquisador, e quando a gente está na assistência, quem está mobilizado, quem pediu para fazer alguma coisa, foi o paciente, inverteu a seta de interesse, de quem busca, e de quem aceitou participar. (...) Então eu sugiro que qualquer hospital universitário, tenha o seu centro de pesquisa para poder separar as coisas (Ana, médica, UFRGS).

A partir dessas falas que descrevem experiências de separação entre atendimento e pesquisa, é possível afirmar que a articulação desenhada entre assistência e pesquisa não é estática, está em transformação. Ainda que os entrevistados descrevam tal articulação como constitutiva do processo de institucionalização e consolidação da área - no contexto brasileiro, mas não somente - há indícios de uma maior profissionalização dos dois elementos, seja em experiências concretas, seja nos discursos mobilizados para defendê-las. Parte dos entrevistados, inclusive, se envolve ou se envolveu, de alguma forma, em um debate mais político, uma atuação para a intervenção na política pública de saúde, de modo a tentar viabilizar uma assistência em genética clínica no âmbito do SUS, muitas vezes via articulação na Sociedade Brasileira de Genética Médica, e, mais recentemente, na formulação da Política 
Nacional de Atenção Integral às Pessoas com Doenças Raras, aprovada em 2014. Essa atuação pode ser vista como uma forma de, justamente, solucionar alguns dos problemas levantados, como a intermitência no atendimento de pacientes, quando ele é feito por razões relacionadas a um projeto de pesquisa, e a falta de financiamento específico para o atendimento, que se sustenta - em parte - via os mesmos projetos de pesquisa.

Se, no momento da institucionalização da genética humana e médica, tal articulação ou mistura - era vista como fundamental para a realização dos trabalhos na área, porque permitia a obtenção de material da pesquisa, a mesma articulação é percebida como trazendo consequências negativas no tempo presente. De um lado, esforços de pesquisa são mobilizados para realizar o atendimento, o que pode dificultar a realização de "pesquisas de ponta", de outro, essa situação, tida como não ideal, tem consequências para o atendimento, visto, em alguma medida, como ainda pouco profissional, intermitente, e, sobretudo, não inserido como deveria sê-lo no Sistema Público de Saúde.

Procurou-se descrever, nesta seção, as diferentes configurações da relação entre genética e medicina, e entre pesquisa e atendimento, em suas diversas dimensões, de modo a explicitar que entre os entrevistados há perfis e posições diferentes nessa relação. Uma das hipóteses auxiliares desta pesquisa é que esses diferentes perfis - mais ligados à pesquisa ou mais ligados à assistência - teriam diferentes formas de relação com o "internacional", diferentes modalidades de inserção em uma divisão internacional do trabalho, e diferentes tipos de colaboração. Tal hipótese auxiliar foi inspirada no trabalho de Pablo Kreimer (2010) sobre a biologia molecular na Argentina, que identificou alguns grupos de pesquisa fortemente integrados, que faziam parte de projetos e programas de pesquisa internacionais, participavam dos congressos internacionais e, muitas vezes, recebiam recursos de origem estrangeira; e outros grupos com integração mais frágil - ou inexistente - e que, portanto, trabalhavam de forma mais isolada, algumas vezes tentando responder às necessidades locais de conhecimento, outras tentando imitar a agenda de pesquisa dos grupos mais integrados. Nesta pesquisa, não encontrei modalidades diferentes de relações com o internacional a partir desses perfis: há entrevistados bastante engajados com a assistência, mas que fizeram doutorado integral em países dos centros, participam de grandes consórcios internacionais e têm muitos artigos em coautoria internacional em periódicos de alto impacto; e há entrevistados mais ligados à pesquisa considerada "básica", biólogos, que não fazem atendimento, e não apresentam trajetórias formativas no exterior nem colaborações internacionais significativas. 
Ao mesmo tempo, ainda que a hipótese não tenha se verificado no material analisado, a descrição dessas relações entre o atendimento de pacientes e a pesquisa permite compreender de forma mais aprofundada o contexto da produção brasileira em genética humana e médica. Ao abordar detalhadamente essas relações, no interior de uma área específica, tal como é o espírito deste trabalho, o que se percebe são diferentes sentidos, situações e configurações específicas. Por exemplo, a elaboração de pesquisas ligadas ao atendimento de pacientes não é monopólio daqueles que atuam diretamente nessa atividade, mas é encontrada também nas práticas de pesquisa de alguns biólogos. Ao mesmo tempo, alguns médicos - que fazem parte de serviços de genética médica - têm projetos de pesquisa desvinculados dessa prática, e que podem ser considerados pesquisa "básica". E há, como visto, diversas combinações realizadas entre atividades propriamente médicas e atividades ligadas à pesquisa científica.

Tais arranjos descritos também serão importantes para compreender as tensões entre a inserção internacional e a inserção local, analisadas no terceiro capítulo da tese. Antes de passar ao segundo capítulo, que abordará alguns aspectos das colaborações internacionais, no intuito de formular aportes no que diz respeito às dimensões da dinâmica centro-periferia, a seguir encontra-se um interlúdio, que apresenta e discute um estudo de caso envolvendo as formas de autoria na genética humana e médica. Essa breve reflexão busca situar um aspecto da divisão do trabalho científico, atentando particularmente a como a prática de coautorias em parceria com colaboradores estrangeiros é levada a cabo, levantando, assim, certos temas que têm ganhado relevância nesse debate contemporâneo. 


\section{Interlúdio:}

Divisão internacional do trabalho científico na genética humana e médica

Um dos objetivos desta pesquisa, tal como exposto na Introdução, era investigar a divisão internacional do trabalho científico no campo da genética humana e médica, a partir de laboratórios brasileiros. Mais do que isso, verificar empiricamente tal divisão do trabalho a partir da análise das contribuições de pesquisadores brasileiros em artigos escritos com colaboradores situados em outros países, para além de discursos, denúncias ou contestações. Buscando, então, testar a hipótese de que é possível falar em uma divisão internacional do trabalho científico na área da genética humana e médica - em termos de centros e periferias o ponto de partida, aqui, é a análise das publicações de pesquisadores em genética humana e médica, a partir do que chamo de discriminação da autoria.

Em outras palavras, tomando por base a análise das contribuições de pesquisadores brasileiros em artigos escritos com colaboradores situados em outros países, verificar em que medida as dimensões apresentadas na Introdução estão presentes na área em questão. Para tanto, foi realizada uma análise dos artigos publicados pela amostra selecionada de 381 pesquisadores da área de genética humana e médica nos periódicos da plataforma Public Library of Science (PLOS). Tal levantamento de artigos foi realizado, em dezembro de 2016, a partir do currículo Lattes dos pesquisadores da amostra, e do próprio sistema de busca da plataforma.

A PLOS é um projeto sem fins lucrativos que tem por objetivo criar uma biblioteca de revistas científicas dentro do modelo de licenciamento de conteúdo aberto, fazendo uso, especificamente, do Creative Commons. A escolha desse conjunto de periódicos para esta análise atende a alguns critérios. O primeiro e mais importante é o de que eles foram um dos primeiros a exigir dos autores a discriminação das atividades de autoria. Em outros termos, para a publicação do artigo é necessário dizer "quem fez o quê" em um artigo. Há certa flexibilidade na forma de se apresentar essa informação, mas a maior parte dos artigos analisados segue as diretrizes fornecidas pelo próprio periódico e divide os autores entre aqueles que conceberam e desenharam os experimentos ("conceived and designed the experiments"), aqueles que realizaram os experimentos ("performed the experiments"), aqueles que analisaram os dados produzidos ("analyzed the data"), aqueles que contribuíram 
com reagentes, materiais ou ferramentas de análise ("contributed reagents/materials/analysis tools", e, por fim, aqueles que escreveram o artigo ("wrote the paper") ${ }^{69}$.

Tal divisão - acompanhada da filiação institucional - dos autores permite analisar, em artigos de coautoria internacional, o aporte dado pelos pesquisadores brasileiros à empreitada científica publicada. Outra justificativa para o seu uso é a importância conferida ao conjunto de periódicos da plataforma, sobretudo o Plos One, bastante utilizado pelos pesquisadores para dar vazão aos seus resultados de pesquisa, e bem avaliado no âmbito do qualis capes:

Tabela 31: Avaliação Qualis Capes do periódico Plos One (quadriênio 2013-2016)

\begin{tabular}{|l|c|}
\hline BIOTECNOLOGIA & $\mathrm{A} 1$ \\
\hline CIÊNCIAS AMBIENTAIS & $\mathrm{A} 1$ \\
\hline CIÊNCIAS BIOLÓGICAS I & $\mathrm{B} 1$ \\
\hline CIÊNCIAS BIOLÓGICAS II & $\mathrm{B} 1$ \\
\hline MEDICINA I & $\mathrm{B} 1$ \\
\hline MEDICINA II & $\mathrm{A} 2$ \\
\hline MEDICINA III & $\mathrm{A} 2$ \\
\hline SAÚDE COLETIVA & $\mathrm{A} 1$ \\
\hline
\end{tabular}

Fonte: Qualis-capes, quadriênio 2013-2016. Elaboração própria.

A PLOS foi fundada em 2000, com uma petição online iniciada por Patrick O. Brown - bioquímico da Universidade de Stanford, ex-diretor dos National Institutes of Health - e por Michael Eisen - biólogo computacional na Universidade da Califórnia, em Berkeley. A petição pedia que todos os cientistas prometessem que, a partir de setembro de 2001, suspenderiam a submissão de artigos para revistas que não disponibilizassem o texto completo de seus artigos a todos, de forma livre e gratuita. Em agosto de 2001, Brown e Eisen anunciaram o início de seu projeto sem fins lucrativos, que começou a ser publicado em $2006^{70}$. O seu financiamento, para além de doações, é realizado majoritariamente pelos autores dos artigos publicados, cujos valores pagos para a publicação se encontra na tabela abaixo:

\footnotetext{
69 A sugestão de trabalhar com um periódico que disponibiliza a discriminação da autoria veio de um dos geneticistas entrevistados, a quem agradeço enormemente.

70 Informações retiradas de https://en.wikipedia.org/wiki/PLOS ONE. Acesso em dezembro de 2016.
} 
Tabela 32: Valores para a publicação na Public Library of Science (2018)

\begin{tabular}{|l|l|}
\hline PLOS Biology & $\$ 3.000$ USD \\
\hline PLOS Medicine & $\$ 3.000$ USD \\
\hline PLOS Computational Biology & $\$ 2.350$ USD \\
\hline PLOS Genetics & $\$ 2.350$ USD \\
\hline PLOS Pathogens & $\$ 2.350$ USD \\
\hline PLOS Neglected Tropical Diseases & $\$ 2.350$ USD \\
\hline PLOS ONE & $\$ 1.595$ USD \\
\hline
\end{tabular}

Fonte: http://journals.plos.org/plosone/s/publication-fees. Acesso em outubro de 2018.

Os artigos são avaliados pelo sistema de revisão por pares, precedido de uma análise interna que lida, principalmente, com as questões de "interesses conflitantes", "exigências éticas exigidas em estudos envolvendo a participação humana" (como estudos que envolvem amostras de sangue de pacientes), e adequação às normas do periódico, que envolve a publicação aberta e a completa disponibilização de dados. O que significa, na prática, que a revista só aceita artigos que estão de acordo com as normas creative commons, que não têm dados patenteados - e portanto não disponibilizados - e que não têm financiamento que possa conflitar com essas regras de submissão.

Antes de passar propriamente à análise dos artigos selecionados por meio dessa plataforma, é necessário fazer uma breve contextualização do debate em torno da autoria na pesquisa biomédica, que em parte é motivador da criação recente da discriminação da autoria em artigos científicos. A autoria científica é comumente definida por meio de uma combinação entre crédito e responsabilidade (Zuckerman, 1968); no entanto, mais recentemente os critérios para qualificar quem deve ser considerado como autor de determinado trabalho tornaram-se espaço de intensos debates (Biagioli, 2013). De um lado, a autoria garante a atribuição de crédito por uma ideia ou descoberta, e, de outro, define a responsabilidade e os direitos sobre ela, além de fornecer as bases para o reconhecimento entre os pares (Merton, 1973), em uma economia em que o capital científico desempenha papel fundamental (Bourdieu, 1975).

A autoria científica tem sido causa de grande preocupação profissional entre os cientistas, especialmente nas atuais publicações com múltiplos autores. Os cientistas, editores e administradores da ciência tornaram-se profundamente preocupados com a ordem de autoria 
das publicações científicas e com a distribuição do crédito em colaborações em larga escala (Biagioli \& Galison, 2013). Ao mesmo tempo, recentes achados de fraude científica chamaram a atenção para a ligação entre a autoria e a responsabilidade, forçando universidades, agências de financiamento e revistas a articularem e reforçarem esse vínculo.

Com o aumento dos trabalhos publicados em coautoria e à medida que o trabalho se torna mais especializado no âmbito das diversas vertentes de Big Science, uma questão premente passa a ser a definição dos critérios de autoria em tais colaborações ${ }^{71}$. $\mathrm{O}$ desenvolvimento de colaborações em grande escala e a publicação de artigos com centenas de autores só agravaram o problema, tornando mais difícil descobrir quais nomes listados deveriam carregar o ônus da responsabilidade: alguns proclamam que cada coautor deve ser responsável por toda a publicação, outros, em vez disso, afirmam que a responsabilidade deve ser limitada à extensão de uma dada contribuição (Biagioli, 2013).

Dadas as consequências dos casos de fraudes na pesquisa biomédica, o International Committee of Medical Journal Editors (ICMJE) - órgão influente que representa centenas de revistas biomédicas anglófonas - exigiu que cada nome listado no artigo se refira a uma pessoa que é inteiramente responsável por todo o artigo e não apenas pela tarefa que possa ter realizado. Mais do que isso, preocupado com o que viu como a inflação do crédito de autoria devido à multiautoria (Biagioli, 2013), respondeu com definições rigorosas de autoria, a partir de quatro critérios, que devem estar presentes simultaneamente ${ }^{72}$ :

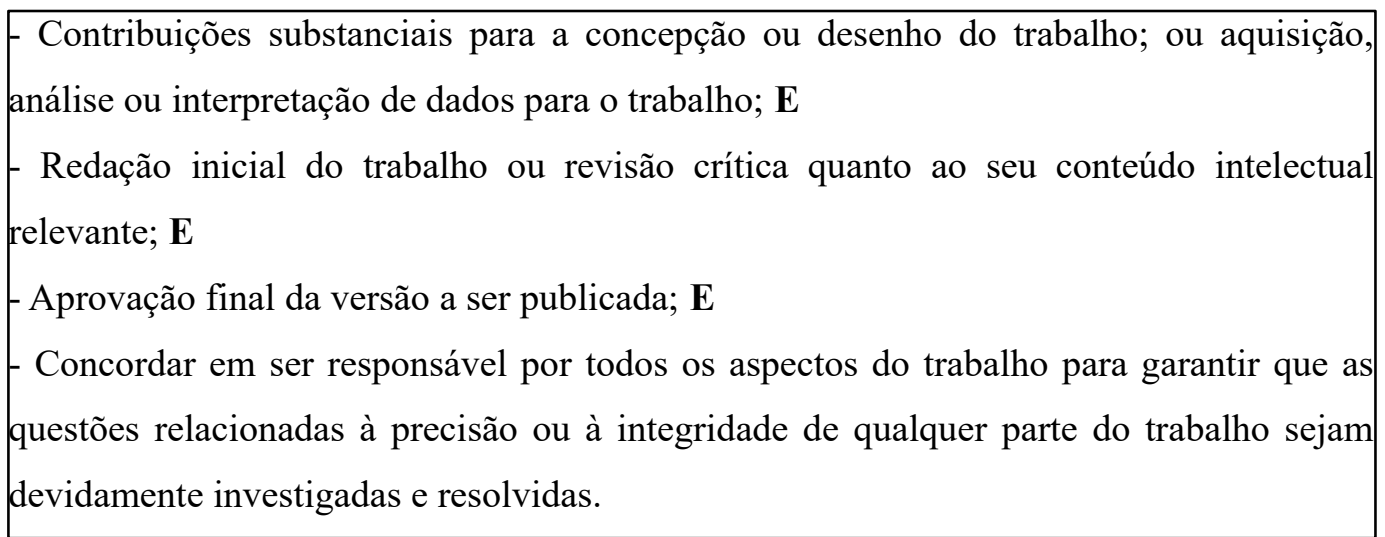

71 Tal como o formulam Biagioli e Galison, em seu trabalho Scientific Authorship (2013), a discussão da autoria na pesquisa biomédica ganhou contornos "práticos" e soluções provisórias, enquanto seu livro busca compreender as implicações teóricas dessas mudanças, dada a combinação de questões literárias, filosóficas, econômicas, históricas e científicas levantadas pela autoria científica. Essa é uma discussão bastante importante que foge ao escopo do presente trabalho.

72 Disponível em: http://www.icmje.org/recommendations/browse/roles-and-responsibilities/defining-the-roleof-authors-and-contributors.html\#two. Acesso em 15 de junho de 2017. 
Nessa acepção, o que qualifica uma pessoa para a autoria são suas contribuições intelectuais, e não outras formas de trabalho que são consideradas não-intelectuais. Vários pesquisadores se opuseram a essa definição. A posição dos críticos foi que eles não podem ser responsáveis pelos aspectos de um projeto que estão fora da sua expertise (Biagioli, 2013). Também argumentaram que uma definição estreita de autoria é injusta para muitos trabalhadores científicos que, embora não se empenhem na conceitualização e redação de uma determinada publicação, viabilizaram-na com seu trabalho (Macauley, 1992).

Em resposta, novas formas de atribuição de crédito apareceram, entre elas a ideia de Contributorship, em que a lista de contribuições específicas de cada autor é colocada no artigo (Lavière et al., 2016). Em artigos publicados no Journal of the American Medical Association (1997; 2000), Drummond Rennie (um dos editores adjuntos) e seus colaboradores argumentaram que cada pessoa que auxiliou de forma útil em um trabalho deve ser listada como "contribuinte", e cada nome deve vir junto com uma descrição da sua contribuição. Essa ideia foi adotada por periódicos em biomedicina a partir do final dos anos 1990 (Wager, 2007). Nessa proposta, a hierarquia entre o autor como o criador dos traços distintivos da obra e os ajudantes, que forneceram as condições de fundo para o trabalho, é substituída por diferentes graus de contribuição; cada pessoa que adicionou algo ao projeto é tratada como um contribuinte (Biagioli, 2013).

Em resumo, como resposta prática às questões relativas à relação entre crédito e responsabilidade em pesquisas publicadas por muitos autores, em um contexto em que fraudes na pesquisa biomédica são cada vez mais frequentes ou visíveis, diversos periódicos e editores começaram a coletar descrições sobre a contribuição individual em trabalhos envolvendo múltiplos autores. Periódicos como o aqui analisado definiram um conjunto de tarefas fixas em que os autores devem ser inseridos, enquanto outros, com a Nature, pedem textos descrevendo as contribuições, sem características pré-definidas; há, ainda, periódicos que solicitam a descrição das contribuições, mas não a publicam (Brand et al., 2015). Ou seja, a discriminação da autoria é um processo em andamento, que não está padronizado, e não é realizado por todos os periódicos da pesquisa biomédica. Ainda assim, argumenta-se, aqui, que a separação e a descrição das contribuições dos diferentes autores - nomeada de discriminação da autoria - permite visualizar processos de divisão do trabalho no interior das colaborações científicas (Lavière et al., 2016), destacando-se ao longo desta investigação os processos de divisão internacional do trabalho. 
O levantamento dos artigos publicados pelos 381 pesquisadores da área de genética humana e médica nesse conjunto de periódicos resultou em uma amostra de 268 artigos, publicados por 180 pesquisadores. Desse conjunto, alguns artigos foram excluídos, por não serem nem ao menos tangencialmente da área de genética humana e médica, tal como artigos em genética de plantas, sendo a distribuição final dos artigos apresentada na tabela abaixo:

Tabela 33: Distribuição de artigos em colaboração, nos periódicos da PLOS (2016)

\begin{tabular}{|l|c|c|}
\hline Tipo de colaboração & Artigos & \% \\
\hline Colaboração internacional & 88 & 35,1 \\
\hline $\begin{array}{l}\text { Colaboração internacional } \\
\text { e colaboração nacional }\end{array}$ & 80 & \\
\hline Colaboração nacional & 53 & 21,1 \\
\hline Colaboração local & 110 & 43,8 \\
\hline Total & & 100 \\
\hline
\end{tabular}

Fonte: Plataforma Lattes e Public Library of Science (PLOS). Elaboração própria.

Em “colaboração internacional" estão classificados os artigos que tem ao menos um autor que está inserido em uma instituição fora do Brasil; foram excluídos dessa categoria autores brasileiros, provisoriamente inseridos em instituições estrangeiras (que estavam realizando doutorado-sanduíche e pós-doutorado). Por "colaboração nacional" entende-se aqueles artigos publicados por pesquisadores de mais de um estado da federação. Em “colaboração internacional e nacional" são classificados os artigos que reúnem entre os autores tanto pesquisadores estrangeiros, quanto pesquisadores brasileiros de mais de um estado da federação. Por fim, designa-se "colaboração local” aqueles artigos em que todos os autores são do mesmo estado da federação e, notadamente, da mesma instituição.

Como o objetivo aqui é analisar possíveis contornos de uma divisão internacional do trabalho científico, serão analisados apenas os artigos escritos em coautoria internacional, embora seja importante destacar que a maior parte dos artigos publicados na Plos - quase $65 \%$ deles - é composta apenas de autores brasileiros. Tal dado é um indício de que, ainda que se trate de pesquisadores ligados a centros de excelência, com inserção internacional relevante, a maior parte da produção científica é feita nacionalmente. Sobretudo, são publicações em que as colaborações se realizam no mesmo estado da federação e, 73 Do total estão excluídos os artigos da linha "Colaboração internacional e colaboração nacional" da tabela, incluídos, também, na categoria "colaboração internacional". 
frequentemente, na mesma instituição, indicando que a área da genética humana e médica ainda é muito ancorada nas estruturas nacionais, regionais e institucionais de produção de conhecimento $^{74}$.

A análise dos artigos escritos em coautoria internacional parte de algumas premissas. Primeiramente, que os autores dos artigos seguem as diretrizes relativas à autoria e que a posição que ocupam é uma aproximação adequada à análise do tipo e grau de contribuição em um artigo científico. No entanto, até o momento não há pesquisa empírica de larga escala que ateste a veracidade dessa premissa, ou seja, não há ainda indicadores confiáveis de que aquilo que está descrito nos artigos é, de fato, o que aconteceu. Além disso, as declarações sobre as contribuições dos diferentes autores ainda não são uma fonte comum de dados para a compreensão das relações entre a autoria e a produção de conhecimento. Elas não são indexadas em bases de dados bibliográficos de grande escala e são apenas exigidas por poucas revistas. Nesse contexto, seria necessária a realização de pesquisas sobre a percepção dos acadêmicos dessas declarações de contribuições bem como acerca do nível de rigor com o qual elas são feitas, o que ajudaria a contextualizar os resultados aqui apresentados.

Como dito anteriormente, as contribuições dos autores são divididas entre categorias preestabelecidas, sendo que os autores podem estar presentes em mais de uma delas, ou mesmo em todas elas. As categorias são: (1) desenho da pesquisa, (2) realização de experimento, (3) análise dos dados, (4) contribuição com reagentes, materiais ou ferramentas de análise, e (5) escrita do artigo. Os artigos foram analisados buscando encontrar o que chamo aqui de tipo ideal da divisão desigual do trabalho científico, e também seu exato oposto, o tipo ideal da divisão igualitária das tarefas.

Caracterizo o tipo ideal da divisão - desigual - do trabalho científico como aquele artigo em que o primeiro e o último autor são estrangeiros ${ }^{75}$ - de países da Europa e Estados Unidos -, o número de autores brasileiros é reduzido, se comparado ao número de pares internacionais, e o papel desses autores está restrito à contribuição "fornecimento de materiais e reagentes" e "realização do experimento", sem uma participação na análise dos dados. Nos

74 Ainda que os dados apresentados sejam insuficientes para discutir grandes tendências, eles indicam que, na maior parta das vezes, o trabalho de produção e análise é feito localmente, entre pesquisadores da mesma instituição ou de instituições vizinhas, e, se uma colaboração é buscada, a orientação não é voltada para outros laboratórios do campo brasileiro, mas sim para os espaços centrais.

75 Há regras formais e informais distintas entre as disciplinas e mesmo entre instituições no que diz respeito à atribuição da autoria (Jabbehdari \& Walsh, 2017). Na genética humana e médica, identificou-se, como critério relevante, o primeiro e último autor de um artigo científico. Como exemplo, tem-se a descrição da autoria feita por um de meus entrevistados na USP/RP: "normalmente o coordenador do grupo fica como último autor, e quem vai escrever o artigo vai ser o primeiro (...), e no meio ficam aqueles que contribuíram, mas que não tiveram papel fundamental". 
artigos desse perfil, a contribuição dos pesquisadores da amostra diz respeito ao fornecimento de dados sobre a população brasileira ${ }^{76}$ - entendida em sentido amplo, incluindo povos indígenas que ocupam o território nacional - a serem somados e comparados com dados de outras populações para responder a questões mais amplas e obter resultados mais generalizáveis, ou com maior grau de abstração.

A construção desse tipo ideal está baseada na literatura que trata das relações entre centros e periferias, que identifica algumas características do contexto periférico, no que diz respeito à marginalidade e à dependência (Keim, 2010). Muito presente, como visto na introdução, é a divisão do trabalho em termos de separação entre a concepção e a execução do projeto (Houtoundji, 2006), e mais especificamente, uma certa divisão entre estudos comparativos e estudos de caso (Alatas, 2003). Para esta análise do campo da genética humana e médica, foi considerado que haveria uma separação entre concepção e análise, de um lado, e execução, de outro, quando o papel ocupado pelos pesquisadores brasileiros era restrito ao fornecimento de amostras da população local, para serem usadas de modo a construir teorias e hipóteses mais robustas e com maior grau de generalização por parte dos pesquisadores dos centros. E são esses os pesquisadores que acumulariam o reconhecimento simbólico, dado que no campo científico há uma hierarquia entre as diferentes contribuições no cenário internacional da ciência, que compreende, de um lado, a concepção de um trabalho e a análise dos dados, e, de outro, o que se pode considerar um trabalho mais técnico de produção de dados (Keim, 2010). Ou, mais simplesmente, uma divisão entre teoria e empiria, sendo a primeira tarefa considerada mais prestigiosa que a segunda.

Artigos desse tipo representam cerca de um quarto da amostra analisada e evidenciam uma relação centro-periferia marcada, em que o Brasil participa da empreitada científica como fornecedor de amostras, mas que serão analisadas nos centros, junto a amostras de outras populações, sejam das periferias ou dos próprios centros. Importante lembrar que contemporaneamente, tal como propôs Hountondji (2006), as periferias não seriam necessariamente apenas exportadoras de dados crus, não-tratados, porque o processo preliminar de tratamento dos dados ocorreria cada vez mais nos países periféricos. Mas esses autores brasileiros, situados no "meio" do artigo, têm pouco controle - e responsabilidade pelas análises e teorizações realizadas. Além disso, ainda que esse tipo de artigo represente $25 \%$ da amostra, ele é relevante porque povoa o imaginário dos pesquisadores em termos do

76 Como a maior parte da pesquisa na genética humana e médica lida com amostras de pacientes de doenças genéticas (genética médica) e de populações humanas "saudáveis" (genética humana populacional), foi feito um levantamento, na seção "material e métodos dos artigos" para verificar de onde provinha a amostra analisada. 
que não deve ser feito, da colaboração a ser evitada, porque percebida em termos de exploração, como será discutido em mais detalhes no terceiro capítulo.

O tipo ideal da divisão igualitária das tarefas é o exato oposto daquele descrito acima: primeiro e último autor encontram-se divididos entre pesquisadores brasileiros e pesquisadores dos centros, configurando uma proporção similar de pesquisadores provenientes dos dois espaços e tendo todas as tarefas compartilhadas entre os pesquisadores, incluindo a produção e análise dos dados, assim como o desenho da pesquisa e a contribuição com materiais e reagentes. Esse tipo de artigo, assim como o primeiro, representa cerca de um quarto da amostra analisada.

É possível afirmar que, embora tenha sido encontrado o tipo de artigo que mais se encaixaria em análises como a de dependência acadêmica (Alatas, 2003) ou de extroversão (Bringel \& Domingues, 2015; Houtoundji, 1990), apresentados na introdução desta tese, eles não estão presentes em quantidade suficiente para afirmar, categoricamente, a existência de uma divisão internacional do trabalho científico marcadamente desigual entre centros e periferias. Ao mesmo tempo, os artigos do tipo ideal igualitário também não se fazem presentes em quantidade suficiente para afirmar, categoricamente, que não há uma divisão internacional do trabalho científico desigual, sendo, então, necessário complexificar e nuançar essas relações discutindo outros tipos de colaboração internacional. Como exemplo, tem-se os artigos em que a maioria dos autores são brasileiros, com material brasileiro, muitas vezes no formato estudo de caso, com financiamento brasileiro, mas há algum pesquisador do centro na lista de autores, que ficou a cargo de uma análise específica que, provavelmente, o mais das vezes não era possível de ser realizada no país. Ou, ainda, os artigos que incluem algum pesquisador estrangeiro, responsável pela instituição internacional em que o primeiro autor realiza estágio - sanduíche ou pós-doutoral. Nos dois casos, há relações assimétricas - como será abordado no capítulo a seguir - porém menos evidentes que no tipo ideal da divisão desigual do trabalho científico.

Nesse sentido, em metade dos artigos é possível ver os dois opostos descritos, um dos pesquisadores brasileiros ocupando o papel de informantes bem-formados (Houtoundi, 2006), e um em que os pesquisadores brasileiros estão em posição simétrica aos seus pares dos centros, e, por isso, não seria possível falar de uma divisão internacional do trabalho com as características da relação entre centros e periferias. A outra metade dos artigos tem, como dito, configurações complexas que precisam ser melhor compreendidas. Esse cenário aponta para um quadro mais heterogêneo e complexo do que aquele imaginado no projeto desta pesquisa. 
Discutiu-se, na Introdução o trabalho de Baber (2003), que analisou empiricamente a diferença entre o localismo e a abstração - a separação entre o trabalho "prático" ou "técnico", atribuído às periferias, e o trabalho "puro", "conceitual" ou "teórico", realizado pelos centros -, tomando por base os títulos das publicações em ciências humanas. $\mathrm{O}$ autor aponta que, em geral, os livros e artigos que tratam das sociedades periféricas têm, no próprio título, a identificação do país ou região em que o estudo foi realizado, enquanto é muito raro encontrar títulos que façam referência aos EUA, Reino Unido ou França, sinalizando que, quando se trata de olhar para essas sociedades, a localização e o contexto não importam, e seus resultados são presumidos como tendo significância universal e não unicamente local.

Quando, visando testar essa hipótese para a minha amostra de artigos, realizei o mesmo tipo de análise para os textos selecionados na plataforma Plos, essa correlação não foi encontrada. Apenas $21 \%$ dos artigos selecionados mencionam, no título, o local de realização da pesquisa - ou a origem das amostras -, não havendo variações significativas ao se olhar para os artigos com ou sem colaboração internacional. Para além de afirmar que não é possível perceber possíveis separações entre o "local" e o "universal”, esses dados também apontam a necessidade de desenvolver análises mais detalhadas das relações entre centros e periferias na genética humana e médica.

Para aprofundar a discussão sobre colaborações internacionais, e aumentar sua complexidade, passo a examinar, no capítulo a seguir, o modo como esses temas apareceram em minhas entrevistas, e avançar no delineamento de dimensões da relação entre centros e periferias identificadas nesta pesquisa. 


\section{CAPÍTULO 2}

\section{Explorando colaborações internacionais: rumo à identificação de dimensões da relação entre centros e periferias}

Tal como explicitado no interlúdio, é necessário discutir de forma mais complexa as relações dos pesquisadores brasileiros da área de genética humana e médica com o internacional, bem como os processos de divisão internacional do trabalho científico, mediante a análise das entrevistas qualitativas realizadas em quatro instituições de ensino e pesquisa: UFRGS, UFPA, Unicamp e USP, campus de Ribeirão Preto. Nesse sentido, este capítulo inicia com uma descrição dos motivos que levam os pesquisadores entrevistados a se engajarem em colaborações internacionais, e a visitarem centros de pesquisa no exterior. Abordar essas motivações significa enfatizar o fato de que aspectos institucionais, socioculturais e econômicos incentivam, refreiam ou mesmo obrigam as colaborações internacionais, bem como enfocar a percepção que os participantes do trabalho conjunto têm sobre seu estatuto científico, em termos individuais e coletivos. A partir dessa primeira exposição de motivos, são identificadas algumas dimensões da relação centro-perferia que serão esmiuçadas na sequência. Essas diferentes dimensões são resumidas na ideia de uma periferia relacional, articulada em termos de falta, entendida em referência a questões institucionais, financeiras, técnicas, culturais e, também, cognitivas.

Destaca-se, aqui, que o recurso às falas dos entrevistados será feito sem grandes restrições, com grande quantidade de citações, de modo a explicitar as principais dimensões das relações entre centros e periferias identificadas por esta pesquisa, bem como esmiuçar os detalhes e tensões presentes nessas relações. O recorte deste trabalho busca compreender, no detalhe, as diferentes relações, tensões e especificidades que marcam a produção, circulação e legitimação do conhecimento na área da genética humana e médica. Além disso, como não foram encontrados dados que se encaixavam em padrões muito definidos de centros e periferias e divisão internacional do trabalho, tal como explicitado no interlúdio, o uso - e abuso - dos relatos dos pesquisadores é a única maneira de compartilhar e analisar os arranjos complexos, a heterogeneidade das posições e, sobretudo, as variações, de acordo com as questões postas aos entrevistados. Trata-se de explorar, em suma, a heterogeneidade das posições no interior de uma certa homogeneidade marcada pelos centros de excelência. Nesse 
sentido, o recurso abundante às falas dos entrevistados foi a maneira que encontrei para compartilhar, também, as minhas "amostras" de pesquisa.

\subsection{Razões para visitar centros de pesquisa no exterior/realizar colaborações internacionais}

As viagens de longa distância e suas correspondentes estadias no exterior ocupam um papel proeminente nas carreiras analisadas. A maior parte dos entrevistados obteve seus primeiros diplomas no Brasil e, nesse sentido, são produtos locais. Mas, no que diz respeito ao treinamento avançado, muitos realizaram estágios doutorais, doutorados integrais e pósdoutorados nos laboratórios de pesquisa localizados em países centrais. Dos 46 pesquisadores entrevistados nas quatro instituições, apenas 14 não tiveram experiência internacional de longa duração ${ }^{77}$, ainda que tenham realizado estágios curtos ou cursos. Nesse sentido, entre os entrevistados, cerca de 70\% tiveram alguma experiência internacional, porcentagem bastante superior aos cerca de $50 \%$ de pesquisadores na mesma situação, na amostra total analisada no capítulo anterior.

Cinco razões foram apresentadas pelos entrevistados para a realização dessas viagens: ter acesso a técnicas de pesquisa, instrumentos e ferramentas de análise; permitir uma maior rapidez no desenvolvimento da pesquisa (acelerar o trabalho); “driblar" o que é percebido como falta de financiamento à pesquisa, no contexto brasileiro; facilitar a publicação da pesquisa realizada; e permitir a participação em pesquisas de "grande amplitude". Passo a discutir mais detalhadamente esses motivos, ordenados pela frequência em que apareceram nas entrevistas.

\subsubsection{Acesso a técnicas de pesquisa}

O principal motivo para a ida a esses centros, explicitado por 40 dos 46 entrevistados, é o acesso a técnicas de pesquisa e, em menor medida, o acesso a ferramentas de análise e instrumentos de pesquisa. Em menor medida os instrumentos, porque, como relatado pelos entrevistados, as políticas científicas mais recentes permitiram a compra de equipamentos ${ }^{78}$, fazendo com que o maior gargalo seja custeio, ou seja, a compra dos materiais necessários para colocar os equipamentos em funcionamento, como será visto mais adiante no capítulo.

\footnotetext{
77 Qualifico como experiência internacional de longa duração aquela de seis meses ou mais.

78 Bicudo (2016) destaca que um elemento importante para a compra de instrumentos entre os grupos de pesquisa brasileiros foi a criação, por parte da Capes, do programa Pró-Equipamentos, em 2007, que permitiu uma certa dispersão de plataformas de sequenciamento de DNA entre diferentes instituições brasileiras de pesquisa.
} 
São muitos os exemplos desse tipo de interação, presentes nas entrevistas. Destaco, inicialmente, uma entrevistada que descreve suas motivações para a realização de um pósdoutorado nos Estados Unidos da seguinte forma:

E o que aconteceu foi que no momento de analisar esses dados, já no final do meu doutorado, me deparei com dados que eram um pouco controversos, quando eu analisava o comportamento daquele gene, daquela molécula que eu estava investigando. E eu queria muito entender o porquê disso. E nesse momento eu me deparei com a dificuldade de ir além, porque aí realmente a gente não tinha as ferramentas, não tinha condições de dar esse salto. Então quando eu fui buscar o desenvolvimento de um projeto de pós-doutorado no exterior o que eu fiz foi ir em busca de pesquisadores que trabalhavam com essa mesma temática (Carolina, bióloga, USP/RP).

Quando descreve o desenvolvimento de seu doutorado, a pesquisadora em questão afirma que todos os elementos necessários para a realização de sua pesquisa estavam disponíveis no laboratório em que se concentrava, mas, no momento em que passou a encontrar "dados que eram um pouco controversos", sentiu a necessidade de buscar uma formação complementar, nos Estados Unidos, no sentido de obter novas ferramentas - ainda não disponíveis em seu grupo de pesquisa - para viabilizar a continuidade de sua pesquisa. Ainda que não fique claro o que exatamente a pesquisadora em questão foi buscar nos Estados Unidos, é possível afirmar que a busca de uma instituição e de um colaborador internacional é uma tendência comum entre os entrevistados, e tem por finalidade principal preencher uma lacuna existente em seu grupo de origem, como fica ainda mais claro na explicação de outra pesquisadora sobre os objetivos de seu estágio doutoral, também nos Estados Unidos:

Faltava para a gente a expertise, o conhecimento de uma ou outra técnica. No meu doutorado eu trabalhei com dois genes diferentes, e para um deles eu pude fazer tudo aqui, a gente tinha tudo. Os equipamentos eram de um projeto da Fapesp do meu orientador, então não faltava nada, assim como no mestrado, tudo foi desenvolvido aqui. Estudei o P53 e o RB1. Para o P53 a gente fez tudo aqui. Para o RB1, a gente precisou de auxílio, porque era um gene muito grande, e precisava de uma técnica diferente. Então eu saí do país, para aprender a fazer, e acabei fazendo tudo lá, fiquei um ano fazendo essa etapa do doutorado (Luísa, bióloga, Unicamp).

O depoimento acima explicita como, ainda que os equipamentos necessários para a realização da pesquisa estivessem disponíveis no laboratório, mediante financiamento de agência de fomento estadual, permanecia a lacuna de uma "técnica", que precisou ser aprendida em instituição estadunidense.

Raciocínio semelhante é utilizado para justificar a necessidade de colaborações internacionais, para além do momento de formação dos pesquisadores, como pode ser visto na 
descrição dos motivos pelos quais um pesquisador da Unicamp busca estabelecer uma parceria com dois laboratórios europeus:

Por exemplo, tanto esse contato que eu estou fazendo com o pessoal da Dinamarca, como da Holanda, é por conta de tecnologia, de expertise, em coisas muito específicas. A gente tem um caso aqui interessante, que a gente precisa mapear pontos de quebra de alterações cromossômicas, e esse pesquisador da Dinamarca é um dos que tem mais experiência nisso no mundo. E a gente nunca fez aqui, então a gente precisa aprender como fazer. Então você vai tentar aprender com quem tem mais experiência, e ele é uma das pessoas que tem mais experiência disso no mundo. O grupo da Holanda é um dos grupos que mais tem experiência em identificar perdas e ganhos de segmentos de DNA em dados de sequenciamento de exoma. É uma coisa que eu acho que é o futuro, e a gente está interessado. Então eu acho que a gente tem que fazer esse tipo de parceria para ter, também, o avanço tecnológico, e aí o avanço de conhecimento (Danilo, biólogo, Unicamp).

De maneira geral, é possível perceber a busca de elementos bastante específicos para viabilizar um projeto de pesquisa, ligados a determinadas técnicas ou tecnologias não existentes nos centros de pesquisa de origem. Na fala acima, por exemplo, fica claro o objetivo de ter um "avanço tecnológico", a partir da colaboração com um grupo considerado mais experiente na técnica pretendida - identificar perdas e ganhos de segmentos de DNA em dados de sequenciamento de exoma -, de modo a incrementar a pesquisa feita localmente. Destaca-se aqui que, tal como explicitado no capítulo anterior, essa é uma área marcada por constantes avanços tecnológicos, associados, na fala acima, com avanços no conhecimento. Ou, em outros termos, tem-se a ideia de que para "avançar" na produção de conhecimento novo, é preciso se apropriar dos "avanços tecnológicos".

No entanto, não apenas novas técnicas são buscadas nessa interação. Ainda que em menor medida, o acesso a "ferramentas de análise" também foi destacado por alguns pesquisadores, sobretudo aqueles que se dedicam aos temas de genética de populações e imunogenética. Essa necessidade é descrita por um pesquisador que realizou seu doutorado sanduíche em Portugal:

Lá eu fiz uma parte do meu doutorado, referente à ancestralidade genômica, fiz mais a parte não-prática do trabalho, a parte voltada para o estudo, análise estatística, e assim por diante. (...) foi mais a análise estatística e a tentativa de padronização do sistema chamado snapshot (...). O snapshot, na época, era um sistema promissor que podia analisar até 60 mutações juntas, então tornaria o trabalho mais rápido e mais barato. (Carlos, biólogo, UFPA)

No caso acima, "ferramentas de análise" é sinônimo de análise estatística - mais precisamente, análise computacional bioinformática - e padronização de um sistema de análise de mutações. Há alguns outros exemplos de busca de ferramentas de análise, como o 
de uma pesquisadora de Porto Alegre que realizou um pós-doutorado na Inglaterra, buscando aprender o "manejo de dados" para definir a contribuição ancestral de diferentes populações. A relação mais direta entre um tema de pesquisa - genética de populações ou genética médica populacional - e uma razão para ir ao exterior - acesso a "ferramentas de análise" -, só foi encontrada aqui, não tendo sido identificados outros padrões no que se refere a temas e razões para colaborar com o exterior.

Os quatro casos citados até aqui representam a ida ao exterior por razões bastante específicas, como ter acesso a uma técnica, um equipamento, ou aprender a fazer determinada análise estatística. Mas há idas mais gerais, com o objetivo de fazer uma "reciclagem" ou uma "atualização", tal como destacam duas pesquisadoras que realizaram seus pós-doutorados, respectivamente, nos Estados Unidos, e na Inglaterra:

A ideia, quando a gente vai para algum lugar, é procurar alguma coisa que esteja relacionada ao que tu já faz ou com algo que tu gostaria de fazer. Para começar a aprender, para visualizar como é o campo, e depois tentar aplicar no retorno. Esse foi o objetivo no meu pós-doutorado, fazer uma reciclagem - acho que essa é uma boa palavra (Erica, bióloga, UFRGS).

\section{Qual era a sua motivação para fazer esse pós-doutorado?}

Era me atualizar. Porque quando as técnicas moleculares começaram a entrar no Brasil, pela literatura a gente percebia que existia uma defasagem bastante importante. Uma defasagem, na época, de uns vinte anos. Então eu concluí o doutorado e logo senti que já estava defasada, que eu precisava me atualizar. E foi essa a principal razão pela qual fui para Londres, fiquei um ano e meio. (Natalia, bióloga, Unicamp).

Para além do que foi definido como uma necessidade de "atualização" - ou, mais especificamente, uma necessidade de acompanhar os novos desdobramentos das técnicas moleculares -, a ida a laboratórios do exterior foi também descrita como "prospecção" de técnicas que sejam viáveis no contexto de pesquisa dos entrevistados, como é o caso da experiência de pós-doutorado de um pesquisador em um instituto de pesquisa ligado aos National Institutes of Health (NIH) estadunidenses:

Fui prospectar técnicas de genotipagem que fossem economicamente viáveis e práticas para a gente fazer estudos em larga escala em genética humana e genética médica de doenças multifatoriais, de transtornos que não são só genéticos, que têm a contribuição de muitos genes com pequeno efeito, mais o ambiente. Lá eu trabalhei bastante com esse equipamento, que é o que a gente acabou comprando depois, aqui, que é o aparelho de genotipagem baseada na emissão de fluorescência (Miguel, médico, UFRGS).

Tem-se a ideia de que é necessário fazer uma mediação da experiência no exterior, selecionando o que pode ser implementado no laboratório brasileiro em que se trabalha, noutras palavras, aquilo que é economicamente viável e "prático" de ser realizado no contexto 
local. A experiência no exterior permite, nesse sentido, mapear o que há de mais novo - e disponível - em termos de tecnologia, mas é necessário fazer uma avaliação cuidadosa do que é possível ser colocado em ação em um laboratório brasileiro, evidenciando que é preciso tomar decisões mediante a disponibilidade - limitada - de financiamento.

Seja para suprir uma necessidade técnica ou tecnológica específica, seja para buscar novas ideias viáveis de como realizar a pesquisa, ou mesmo fazer uma "reciclagem", a ida para centros de pesquisa no exterior é uma característica marcante da trajetória dos pesquisadores entrevistados. No entanto, mais que o acesso pontual a novas técnicas, equipamentos ou ferramentas de análise, o que marca os relatos dessas experiências é a ideia de "aprender" com os centros de pesquisa considerados mais avançados. Essa discussão será retomada adiante neste capítulo.

Matthieu Hubert e Ana Spivak L'Hoste (2009), discutindo modalidades de inserção em redes internacionais e locais de colaboração, na área de nanotecnologia, na Argentina, afirmam que um dos seus principais achados de pesquisa é o de como as redes são estruturadas primeiramente como uma estratégia de acesso a instrumentos. No caso da genética humana e médica no Brasil, esta pesquisa mostrou tratar-se de uma dimensão importante, mas não fundamental. Ainda que a instrumentação seja fundamental para a realização da pesquisa na área, os pesquisadores indicam que, com as políticas de financiamento recentes, muitos equipamentos puderam ser comprados, não sendo a colaboração internacional necessária para ter acesso a instrumentos não disponíveis no contexto local. Ao mesmo tempo, é importante destacar que, como os próprios pesquisadores ressaltam, a instrumentação muda rapidamente devido ao desenvolvimento tecnológico, de modo que cortes no financiamento podem, em curtos períodos de tempo, aumentar a necessidade de colaborações para ter acesso a equipamentos.

\subsubsection{Maior rapidez no desenvolvimento da pesquisa}

O segundo motivo mais citado para ir ao exterior ou ter colaborações com o exterior que apareceu em 15 entrevistas - está relacionado ao primeiro, ainda que não seja a ele idêntico: não se trata do acesso a determinada técnica ou instrumento não disponível localmente, mas sim de realizar mais rápido uma tarefa, ou conjunto de tarefas, que poderiam, em princípio, ser realizadas em laboratórios brasileiros. Descrevendo seu estágio doutoral em Portugal, uma entrevistada de Belém afirma: 
Eu executei a genotipagem de microssatélites usados para marcação de ancestralidade, tanto nas amostras que eu levei do Brasil (...), quanto nas amostras de populações africanas.

\section{A parte prática que você fez lá você não conseguiria fazer no Brasil?}

Sinceramente eu conseguiria. O que me motivou a ir para lá é que eu estaria perto do grupo de pesquisa que estava trabalhando com isso (...). Mas é bem claro para mim que muitas das coisas que eu fazia lá eu poderia fazer no Brasil. Mas a experiência técnica do grupo, para fazer funcionar um experimento que não era tão simples, também contava muito para mim, eu tinha pouco tempo para fazer; então até padronizar tudo que se estava fazendo era melhor utilizar o que estava pronto (Monique, bióloga, UFPA).

A pesquisadora destaca que, embora o laboratório na USP no qual realizava seu doutorado tivesse a infraestrutura necessária para realizar a técnica pretendida - a genotipagem de microssatélites usados para marcação de ancestralidade -, ela ainda não estava "padronizada" - não era realizada rotineiramente em seu contexto de trabalho - e levaria tempo para ser implementada, atrasando o desenvolvimento da pesquisa. Nesse sentido, a expertise já existente no laboratório visitado permitiria realizar o trabalho mais rapidamente. Ainda que seja possível aprender novas técnicas lendo artigos científicos e tentando montar os procedimentos descritos, os entrevistados destacam que a melhor forma de aprender é "in loco":

Fiquei conhecendo esse modelo [animal] num congresso. E depois eu fui atrás do pesquisador, falei "onde é que está esse cara? Porque eu quero trabalhar com esse modelo". Eu identifiquei que ele estava nesse grupo na Alemanha, e então o [meu aluno] foi para lá para aprender o modelo. Porque a melhor maneira de você aprender é você ir in loco, porque sempre tem o pulo do gato (Sofia, médica, Unicamp).

Fui [para Inglaterra] aperfeiçoar, aprofundar, coisas que eu tinha feito em Ribeirão Preto. (...) Um aprofundamento, porque na época eu já fui trabalhar com sequenciamento de DNA (...).

\section{E isso você não conseguiria fazer no Brasil, naquela época?}

Eles tinham uma abordagem que é, digamos assim, um pulo do gato, eles tinham descrito recentemente uma técnica, que permitia analisar com mais definição. A gente podia tentar fazer aqui, mas eles tinham descrito um procedimento que resolvia alguns problemas metodológicos, que a gente não tinha aqui. Por isso fui para lá, para aprender a fazer, ver na prática como é que se fazia isso, para poder voltar e fazer aqui. (Matheus, médico, UFPA).

Por mais que uma determinada técnica esteja padronizada ${ }^{79}$ e bem descrita na literatura científica, os pesquisadores destacam que há o "pulo do gato", algum detalhe que faz a diferença na realização do procedimento, e que pode ser compreendido mais

79 A padronização-estabilização (Collins, 1975) é um processo histórico nas ciências, e quanto mais ela assume um caráter internacional, mais faz com que apenas equipes que tenham acesso a determinadas relações com os centros (e, portanto, acesso ao uso de insumos e equipamentos necessários de acordo com as normas mais ou menos explícitas que esse processo supõe) possam trabalhar com uma determinada agenda de pesquisa. 
rapidamente, ao ir aprender com quem já realiza o procedimento. O que está em questão aqui é mais do que aprender alguma minúcia não publicada: para além das explicações mais objetivas - é mais rápido, tem o equipamento necessário - os centros são retratados como possuindo um ambiente de aprendizado, aprendizado esse marcado, mesmo com a padronização, pela necessidade da interação face a face. Destacam-se, aqui, elementos menos formalizados do aprendizado, que são difíceis de serem apreendidos exclusivamente pela literatura científica, que precisam ser vistos "na prática", o que remete a questões que são da ordem da experiência, de conhecimentos que podem ser identificados como tácitos. Assim, subjacente ao motivo mais explícito, de ir ao exterior com o objetivo de realizar determinadas etapas de maneira mais veloz, evitando, também, alguns entraves que serão explicitados no item 3.2, tem-se a ideia de que a experiência do (e no) grupo visitado é crucial para a aprendizagem e posterior padronização de técnicas de pesquisa.

\subsection{3 "Driblar" a falta de dinheiro}

O terceiro motivo para realizar colaborações com centros de pesquisa em outros países, presente em 13 entrevistas, é o que chamo aqui de "driblar" a falta de dinheiro para a pesquisa no contexto local. Nesse caso, menos do que ter acesso a técnicas, equipamentos ou ferramentas de análise, ou realizar rapidamente determinadas tarefas, tem-se a ideia de realizar determinadas etapas que poderiam - tecnicamente - serem realizadas no país, mas que, por dificuldades financeiras, são executadas em laboratórios dos centros. No entanto, é importante destacar que esse tema aparece mais comumente nas entrevistas da UFRGS e UFPA do que naquelas realizadas no estado de São Paulo, cujo acesso às linhas de financiamento da Fapesp significa, ao menos em potencial, uma quantidade maior de recursos para a pesquisa. Essa constatação abre as portas para que se pense as hierarquizações e diferenciações internas à periferia, conforme será discutido mais adiante.

Descrevendo suas motivações para a realização de um pós-doutorado na Inglaterra, uma pesquisadora destaca as limitações financeiras de seu contexto, naquele momento, e a rapidez do desenvolvimento tecnológico, que torna o seu acompanhamento mais difícil.

Eu já estava trabalhando em uma área que a gente chama de genética médica populacional, genética médica aplicada às populações (...). E qual a diferença? Por que não fazer aqui? Aí sim, a diferença da tecnologia e do dinheiro. O que eu quero dizer? No Brasil nós temos um conhecimento fantástico, sobre um monte de coisas, mas o dinheiro para fazer alguns tipos de análise, e em grande número, é muito limitado. E a tecnologia em análise de DNA vai indo muito rápido e nós temos às vezes dificuldade de 
acompanhar, nós temos às vezes números amostrais pequenos etc. Então fui para lá para entender esse manejo de dados (Rita, médica, UFRGS).

Para além da experiência internacional de formação - ou mesmo o pós-doutorado, como no relato acima - as colaborações internacionais, de forma mais geral, foram muito destacadas como uma estratégia para a continuação das pesquisas, principalmente em momentos de diminuição do financiamento nacional da ciência.

Por exemplo, os colaboradores foram muito importantes nesse período de dois anos de crise - agora os investimentos estão sendo retomados, mas parou tudo, não tinha dinheiro, não tinha nada. E o que tu faz? Tem dez estudantes, o que tu faz? Originalidade, muita análise de dados que já existem, genomas e genomas que a gente pode olhar $\left[{ }^{80}\right]$ (...). Mas, ainda assim, nesse momento foi muito importante ter as colaborações, tanto que, aqui, todo mundo que pediu para estudante ir para algum lugar conseguiu a autorização do programa para ficar seis meses, um ano fora. (...) É mais vantajoso tu pagar uma passagem para alguém passar seis meses fazendo um experimento na Alemanha, nos Estados Unidos, na Inglaterra, do que ficar aqui sem os recursos. Aí a colaboração está sendo fundamental para nós, por conta do volume de recurso para pesquisa, não estou falando da bolsa do estudante ou a passagem. Se tu tens um bom colaborador, um projeto que pode custar 100 mil reais o estudante faz lá. (Vanessa, bióloga, UFRGS).

$\mathrm{Na}$ fala acima, resume-se com nitidez essa razão específica para colaborar com o exterior. Em um contexto de "crise", que limitou significativamente os investimentos em pesquisa no país, a colaboração internacional aparece como estratégia de viabilização de pesquisas - nesse caso, doutorados de alunos. Nesse sentido, pesquisas custosas, que envolvem equipamentos sofisticados e reagentes caros de pesquisa, podem ser realizadas em laboratórios internacionais, se o pesquisador brasileiro encontrar um "bom colaborador" internacional disposto a financiar a realização desses experimentos.

Descrevendo especificamente um artigo publicado em coautoria internacional, uma pesquisadora expõe que a colaboração aparece como uma alternativa não apenas para realizar experimentos mais rapidamente, driblando a espera por insumos de pesquisa, mas também para realizar etapas custosas da pesquisa, em que, ainda que o país tenha capacidade técnica para realizá-las, não há financiamento suficiente, ao menos não naquele momento:

Então fizeram esse projeto, coletamos as amostras, mas por conta da nossa limitação financeira - não foi técnica, foi uma limitação financeira - a gente não conseguia fazer uma análise completa, só conseguia fazer uma análise parcial das amostras. E eles tinham esse contato com o [pesquisador estadunidense]. Esse rapaz que já tinha uma colaboração com outro grupo no Brasil ficou sabendo... Como é que acharam o guri eu não sei, mas ele veio

\footnotetext{
80 "Genomas e mais genomas que a gente pode olhar" se refere tanto a dados produzidos pelo seu grupo, em pesquisas anteriores, quanto a dados disponíveis em bancos de dados internacionais, como o National Center for Biotechnology Information (NCBI).
} 
e disse "olha, tenho muito interesse em fazer isso, vou levar as amostras e vou fazer lá". E ele levou as amostras e fez.

Você disse que não era uma dificuldade técnica, era financeira...

Isso. Não é que a gente não tenha equipamento, não tinha o dinheiro para fazer a análise, não tinha dinheiro para o reagente (Thais, bióloga, UFRGS).

Como é possível observar nas falas acima, a estratégia de buscar colaborações internacionais para lidar com a percebida escassez de recursos locais foi realizada tanto no âmbito de um projeto ou questão de pesquisa individual, que resultou em uma publicação, quanto no âmbito de um programa de pós-graduação, para a conclusão de pesquisas realizadas pelos alunos, que, se não é incentivada institucionalmente, ao menos é sancionada como tal.

É importante frisar, no entanto, que, embora os pesquisadores destaquem a possibilidade de lidar com a falta de recursos indo para laboratórios no exterior - que custeiam seus experimentos -, quase todos os pesquisadores entrevistados tiveram sua ida e estadia custeada por fundos públicos, por meio da concessão de bolsas. Há aqui três elementos distintos quando se fala em financiamento: bolsas para a realização de estágios doutorais e pós-doutorado em outros países; financiamento para compra de equipamentos, que, como visto, não é percebido como um entrave; e financiamento de material de custeio para a realização de experimentos no laboratório. É nesse último sentido que a falta de financiamento justifica as colaborações internacionais, financiadas mediante bolsas de pósdoutorado e doutorado sanduíche, por parte da política científica nacional.

Ao mesmo tempo, essa estratégia de "driblar" a falta de dinheiro realizando experimentos custosos em laboratórios dos centros tem algumas consequências, como evidenciado na seguinte entrevista:

Para ser sincera, hoje, a gente tenta ao máximo fazer as coisas aqui. A gente pode ter colaborações, mas o que nós temos de mais importante? A gente não tem tanto dinheiro, tecnologia até temos, temos os equipamentos, mas às vezes a gente não tem o dinheiro para realizar pesquisas. O que a gente tem de mais valioso são os nossos pacientes. O pessoal é louco para fazer colaboração com o Brasil, porque eles querem que a gente mande os pacientes para lá, e a gente não quer, a gente quer fazer aqui. A gente mantém as colaborações e a gente só manda DNA para fora em último caso.

O "em último caso" é quando é uma coisa que não dá para fazer aqui?

Quando não dá para fazer aqui, quando eu não tenho dinheiro para fazer aqui, pelo paciente a gente manda. E assim, com muitas restrições, eu mando, mas a publicação é conjunta, com tudo isso (...). E a gente faz colaboração, realmente, para buscar técnicas, para buscar dinheiro. Eu mandei agora um monte de amostras para [o exterior], para fazer sequenciamento. Eu posso fazer aqui, mas não tem dinheiro. E eles falaram: 'a gente faz, vocês analisam, e depois publicamos juntos'. Tem que mandar, fazer o quê? Sendo que eu poderia publicar aqui e ter todo o mérito só nosso, se a gente tivesse condições financeiras (Sara, bióloga, Unicamp). 
Ao realizar a pesquisa em colaboração, o trabalho deixa de ser de responsabilidade de um grupo apenas de brasileiros, e o "mérito" (ou o reconhecimento) passa a ser dividido entre os diferentes grupos que compõem aquela pesquisa. Ao definir a colaboração internacional como estratégia para o avanço da pesquisa em condições adversas, abre-se mão de obter todo o reconhecimento fruto daquele trabalho, cuja ideia, hipótese e material - amostras de pacientes - são produtos locais. Nesse sentido, explicita-se uma tensão: de um lado a preocupação com uma certa autonomia da pesquisa brasileira, mas, de outro, uma constatação de que se a colaboração internacional for a única forma de "fazer ciência", contemporaneamente, ela deve ser buscada:

Deixa eu te explicar, atualmente, para fazer pesquisa relevante, tu precisa poder fazer exoma, e uma série de coisas que são muito caras em um número muito grande de pessoas. E nós aqui não conseguimos fazer às vezes nem para os nossos pacientes. Então existe um gap muito grande pelo preço de fazer uma ciência de ponta. (...). Então a gente depende - mesmo nós - de colaborações internacionais; nós não podemos dizer que nós não queremos mais os estrangeiros, nós queremos, e a gente vai mandar amostra para eles porque às vezes essa é nossa única possibilidade de fazer um negócio decente, considerando o conhecimento atual, porque não adianta fazer ciência dos anos 1990, sabendo que o mundo está em 2017, eu também não sou Dom Quixote (Rita, médica, UFRGS).

Ainda que haja uma preocupação envolvida com a colaboração internacional, no sentido de ter que dividir um trabalho - e o reconhecimento desse trabalho - que, sob condições mais favoráveis, poderia ser realizado inteiramente no país, os pesquisadores reafirmam que se a única forma de avançar na pesquisa for essa, se a única forma de não fazer "ciência dos anos 1990" - pesquisas com técnicas e instrumentos defasados - for essa, a estratégia será seguida. As tensões entre colaboração internacional e uma certa perda de autonomia serão discutidas em mais detalhes no próximo capítulo.

\subsubsection{Facilitar a publicação da pesquisa}

A quarta razão, presente em sete entrevistas, é que a colaboração internacional pode facilitar a publicação de um artigo. Aqui não se trata exatamente de ter acesso a técnicas que possam deixar o trabalho mais robusto, ou de uma maior rapidez para a obtenção dos resultados, nem mesmo de uma limitação no financiamento, mas da inclusão de uma certa legitimidade simbólica fornecida pelo nome de um colaborador internacional. Nesse sentido, mais do que aumentar a qualidade de um artigo, incluindo mais técnicas ou testes mais sofisticados, o que está em questão é o aumento da "qualidade simbólica" da publicação. 
Discutindo as possibilidades de reconhecimento internacional da genética brasileira, um pesquisador sênior relata que se beneficiou de "associações" com pesquisadores importantes, que abriram as portas não só para a realização de pesquisas de qualidade, mas para a publicação dessas pesquisas com certa facilidade:

Esse negócio do reconhecimento internacional é muito complicado, depende muito das associações que a gente tem com determinados tipos de pessoas, ou grupos. No início da genética, nossos trabalhos foram muito beneficiados em termos de repercussão internacional pelo Dobzhansky, que, então, fazia trabalho de campo, como nós, analisava os dados com a gente, mas que tinha uma influência, ele era um membro da Academia de Ciências dos Estados Unidos, e então qualquer artigo que ele enviasse para publicação tinha um certo respeito. A mesma coisa com o Neel, ele era uma pessoa reconhecida internacionalmente, uma pessoa muito importante. Então essas associações facilitam, né? Porque uma coisa é um artigo ser encaminhado por um pesquisador do Brasil, ou da Bolívia, outra coisa é ser encaminhado por um pesquisador dos Estados Unidos, ou da Grã-Bretanha; de início, o revisor já fica de sobreaviso, "deve ser porcaria" (Joaquim, biólogo, UFRGS).

Contemporaneamente, esse tipo de "associação" continua fazendo sentido, como descreve um pesquisador que buscou ativamente a colaboração com um par da Espanha, com o objetivo, entre outros, de intermediar a publicação de um artigo:

E eu tenho uma colaboração muito antiga com um pesquisador espanhol, com quem eu publico muito (...). E ele tem muito nome internacional, para os projetos que eu consegui dinheiro de fora, ele foi muito importante, porque ele intercede por mim lá fora. (...). É uma pessoa a quem devo muito porque ele intercedeu por mim com pessoas que não me conheciam lá fora, disse: "eu sei quem é, vocês podem confiar" (...).

Você poderia detalhar um pouco melhor como é essa colaboração?

Foi o seguinte. Eu mandei para ele ler um artigo meu, e ele gostou. E eu disse que seria muito importante que o nome dele fosse no artigo, que ele fizesse as considerações e entrasse o nome dele no artigo, porque como ele tinha um nome muito forte, e eu queria mandar para uma revista europeia, e o nome dele ia reforçar a entrada do artigo lá (Augusto, biólogo, UFPA).

A colaboração internacional poderia conferir, então, "credibilidade" ao trabalho, ou maior "respaldo da comunidade científica". A colaboração aparece como algo próximo a uma condição para concorrer em pé de igualdade na competição por publicação, ainda que não seja condição suficiente e, portanto, garantia de conseguir publicar determinado artigo:

Essa é uma das coisas que a colaboração internacional traz, você colocar na lista de autores pessoas de outros países, isso dá uma certa credibilidade ao teu artigo, acho. Não no sentido que vai publicar porque colocou o nome de alguém importante na área, mas significa que estão endossando seu artigo pessoas de universidades e de grupos distintos, isso dá uma certa credibilidade (Lucas, biólogo, UFPA).

Outra vantagem de você fazer colaboração é a seguinte: quando você submete um artigo com o nome de um pesquisador de peso, numa revista de 
prestígio, ele é visto com outros olhos né? Para eles mandarem para o referee é mais fácil. Quando manda um artigo do Brasil, a resposta é "não está no escopo da nossa revista". É comum. Mas se tem o nome de um bambambam ali no meio, já olham diferente. Tenho certeza (Sara, bióloga, Unicamp).

Um colaborador internacional tem condições de esclarecer melhor o grupo, se houver algum problema. Às vezes, só o nome dele estando lá no artigo, e o pessoal já olha diferente, porque ele tem o respaldo da comunidade científica, ele é uma pessoa respeitada, então isso ajuda. Mas está mudando isso, o Brasil hoje tem publicações de alto impacto só com brasileiros, em boas revistas. Ainda é pequeno isso, se concentra em alguns grupos, alguns centros, mas existe (Leandro, biólogo, USP/RP).

Nota-se, aqui, uma certa tensão: ao mesmo tempo em que, de modo explícito, afirmase que o artigo não será publicado apenas por causa do nome estrangeiro, diz-se, também explicitamente, que por vezes ele sequer seria enviado à análise por pares sem esse endosso. Essa tensão se explicita ainda mais na fala de alguns pesquisadores que afirmam ter dúvidas se tal estratégia realmente funciona, e, também, se ela é benéfica para a pesquisa brasileira.

Eu acho que essa ideia de que você dá um up no seu paper colocando um nome de um famoso lá no meio é tristonha, porque, para começar, eu acho que não funciona. Porque, se o nome do fulano está lá no meio, qualquer revisor vai saber o que aconteceu, que ele não é o dono da criança, que ele não é o supervisor. É até estranho, porque você está tão acostumado a ver um nomão como o último autor, se ele está no meio você pensa: "será que isso daqui é do bom? O que ele fez? Ou será que é, assim, um acréscimo de misericórdia?" (Fabricio, biólogo, USP).

Mas essa forma de driblar é um beco sem saída, pelo que eu te falei, se tu faz muita colaboração, tu vai ficar dependente do outro, tu não cria autonomia (Ana, médica, UFRGS).

A fala imediatamente acima adiciona uma nova camada: mais do que ter dúvidas se a estratégia de inclusão de nomes internacionais para facilitar a publicação de uma pesquisa é eficaz, o que está em questão é a construção de uma dependência desse reconhecimento simbólico dos centros, e, como consequência, uma dificuldade crescente de se obter autonomia local. Subjacente a essa discussão, há uma questão que divide muito os pesquisadores entrevistados: se há ou não uma dificuldade adicional - ou mesmo preconceito - para se publicar um artigo só com nomes brasileiros da genética humana e médica. Esse tema será posteriormente retomado, no item 2.3 deste capítulo.

\subsubsection{Participação em pesquisa de "grande amplitude"}

A última razão, destacada também em sete entrevistas, é a ideia de que a colaboração internacional permite a participação em pesquisas de "grande amplitude", pesquisas mais 
amplas que reúnem um número grande de amostras ou uma diversidade de técnicas e abordagens, de modo que não seria possível de ser realizada apenas em nível local:

Acho que essa colaboração com o exterior é decisiva no desenvolvimento da pessoa, do pesquisador.

Mas decisiva em que sentido? No que se ganha?

$\mathrm{Eu}$ acho que ganha-se no seguinte sentido, você participa de grupos que atuam em pesquisa, vamos dizer assim, não só de grande amplitude, mas de nível tecnológico muito avançado. No nosso caso, de genética de populações humanas, o que eu chamo de amplitude? São grandes amostras, você pegar amostras de vários países. Então, se você não participar desses grupos, você não tem acesso a isso. Claro que você pode ainda fazer trabalhos com amostras pequenas, como esse que nós estamos fazendo aqui, mas se você tem interesse em participar desses grandes consórcios, você tem que estabelecer uma colaboração e você tem que fisicamente passar um tempo com alguns desses membros do grupo (Vinícius, médico, USP/RP).

O depoimento acima destaca que, para participar de pesquisas de "grande amplitude", é necessário integrar consórcios - grandes colaborações envolvendo diversos grupos, de modo a unir grande quantidade de amostras, que permite, também, a elaboração de questões de pesquisa amplas. Além disso, está presente uma ideia importante, de que para estabelecer colaborações é necessário passar algum tempo com os membros dos grupos que participam dos grandes consórcios. Nesse sentido, não é só o aprendizado que necessita, muitas vezes, da interação face a face, sendo que esta também facilita o estabelecimento de colaborações, pressupondo a ideia de que haveria dificuldades adicionais de estabelecer parcerias a distância, sem um contato presencial.

Para além da concentração de amostras que a colaboração pode proporcionar, evidenciam-se, também, os benefícios existentes ao haver uma concentração de pesquisadores trabalhando em um mesmo assunto:

No doutorado era um projeto em que eu era a principal pessoa, além, claro, dos meus orientadores, mas no pós-doutorado [na Inglaterra] éramos duas ou três pessoas trabalhando em uma mesma pesquisa, claro que cada uma num aspecto diferente, mas rendeu uma publicação que tinha mais de uma pessoa que trabalhava intensamente no assunto (Erica, bióloga, UFRGS).

Nesse sentido, a "amplitude" pode ser pensada em termos de número de amostras e a consequente formulação de questões de maior envergadura, ou, tal qual no exemplo acima, como a quantidade de pesquisadores trabalhando "intensamente" em um mesmo tema, permitindo, também, discussões mais amplas, em contraposição a uma pesquisa realizada individualmente, durante o doutorado no Brasil.

A partir dessa primeira incursão de análise das entrevistas, foi possível identificar cinco razões para a realização de colaborações internacionais, sumariadas no quadro abaixo: 


1. Acesso a técnicas, instrumentos e ferramentas de análise
2. Maior rapidez no desenvolvimento da pesquisa
3. "Driblar" a falta de dinheiro
4. Facilitar a publicação da pesquisa
5. Participação em pesquisa de "grande amplitude"

Para melhor compreender essas razões, no entanto, é preciso articular algumas dimensões do que é percebido como entraves na realização de pesquisas em genética humana e médica, no contexto brasileiro. Subjacente à discussão dos motivos para a colaboração internacional, quando é solicitado aos pesquisadores que fizeram ao menos um estágio fora do país - que, como visto, é sinônimo de uma experiência nos Estados Unidos, Canadá e alguns países da Europa, como Inglaterra, Alemanha, Espanha e Portugal - para comparar as suas experiências de fazer pesquisa no Brasil e fora do Brasil, fica marcada a ideia de uma periferia pensada em termos de falta.

\subsection{Periferia pensada em termos de "falta": contextualizando o cenário das colaborações internacionais}

Nas entrevistas, a comparação entre a experiência de pesquisa no contexto local e a vivência no exterior destaca, sempre, as facilidades obtidas nos locais visitados, e poucas menções são feitas a algum tipo de vantagem ou aspecto positivo da experiência brasileira. Nesse sentido pode-se afirmar que, ao articular discursivamente as diversas características dos dois espaços, o contexto local é sempre descrito em termos de "falta". Primeiramente, faltam recursos para realizar a pesquisa: os lugares visitados no exterior sempre dispõem de mais recursos, seja em termos de equipamentos disponíveis, seja em termos de financiamento.

\section{Naquela época era muito diferente fazer pesquisa lá e aqui?}

Sempre tem diferenças. Por exemplo, eu estava na Inglaterra, e muitos lugares na Inglaterra e Estados Unidos, têm uma boa diferença, principalmente em relação à verba (Erica, bióloga, UFRGS).

Por exemplo, o sequenciador que nós discutimos antes, houve uma época que no Brasil tínhamos cinquenta, enquanto na Inglaterra tinha um laboratório com 200, apenas um laboratório. E aqui nós achávamos que tínhamos muitos sequenciadores, e temos mesmo. Mas se você pegar a média, a China, por exemplo, está lá com não sei quantos milhares de sequenciadores, tudo em linha (Vinícius, médico, USP/RP). 
A primeira fala, de uma pesquisadora de Porto Alegre que realizou todo o seu doutorado na Inglaterra e um pós-doutorado nos Estados Unidos, destaca que a diferença mais marcante que ela encontra, se comparado à instituição na qual trabalha no Brasil, é a disponibilidade de verbas para a pesquisa. Já no segundo depoimento, o pesquisador de Ribeirão Preto destaca que o laboratório que visitou na Inglaterra tinha mais sequenciadores que em todo Brasil, apesar de reconhecer que não considera pequeno o número de equipamentos disponíveis no contexto local. Nos dois casos, o destaque está nos recursos mais escassos para a pesquisa no Brasil, em comparação com os laboratórios visitados.

Ao mesmo tempo, se um pesquisador de Ribeirão Preto, olhando para a Inglaterra, caracteriza a sua situação como de falta de equipamento, um pesquisador de Belém, que realizou o doutorado na USP de Ribeirão Preto - e o mestrado no Canadá - compara a experiência de pesquisa nos dois laboratórios brasileiros da seguinte forma:

\begin{abstract}
A agência de fomento deles, a Fapesp, é uma coisa fantástica. Então tem muito dinheiro, muito dinheiro, os alunos lá têm bolsa, aqui muitos alunos não têm bolsa. Isso dá uma cara diferente. Não que eles sejam pesquisadores melhores, eu costumo dizer que lá o que eles têm é mais dinheiro. Cabeças boas a gente tem lá, cabeças boas a gente tem aqui. A questão é que aqui a gente não tem dinheiro e lá eles têm bastante dinheiro e isso, com certeza, faz a diferença. Não faltava material, era quase um Canadá. Não era um Canadá, porque o Canadá era um absurdo, eu pensava em água destilada para fazer meu experimento, e no dia seguinte o cara já estava lá com a água e uma pipeta (...). A gente trabalha com muita dificuldade, aqui em Belém, nessa área de tecnologia (Jessé, biólogo, UFPA).
\end{abstract}

Nesse sentido, a mesma descrição, do centro como o lugar que tem mais recursos, pode ser verificada em termos regionais: se no Canadá, onde o pesquisador realizou seu mestrado, os recursos eram muito abundantes, se comparados a Ribeirão Preto e Belém, quando se compara os dois últimos, a relação que se estabelece é a mesma, com Ribeirão Preto sendo considerado um lugar que tem "muito dinheiro" para a pesquisa.

No entanto, ainda que a disparidade de recursos financeiros e equipamentos - entre centros e periferias - tenha sido mencionada em algumas entrevistas, a principal diferença, destacada por todos os pesquisadores que tiveram alguma experiência internacional, diz respeito ao tempo. Os centros visitados são vistos como espaços em que a pesquisa se desenvolve de maneira mais rápida, em que os materiais necessários para o trabalho são obtidos com mais agilidade:

Como te disse antes, se você me pedir para dizer uma técnica que só é feita lá fora, e que aqui eu não tenho condições de fazer, é difícil. Tem. Se não tiver no meu laboratório, tem na USP de Ribeirão Preto, na USP de São Paulo, na Unicamp, em algum lugar vai ter. Então a gente tem condições de 
fazer basicamente tudo que eles fazem lá fora, em termos de equipamento. $\mathrm{O}$ problema é que ter o equipamento que permite fazer uma metodologia de ponta não garante que o desenvolvimento da sua pesquisa ocorra de maneira rápida, e que progrida de uma forma que você consiga competir com o que está acontecendo lá. Por que? Porque se eu tenho o equipamento em um determinado instituto do estado de São Paulo, quando eu for comprar esse reagente ele vai custar três vezes mais, ele vai demorar três vezes mais para chegar aqui. E a gente começa a lidar com alguns entraves que fazem com que a gente já saia perdendo nessa corrida (Carolina, bióloga, USP/RP).

Em termos de conhecimento a gente é muito parecido. Em termos de infraestrutura, dependendo do local no Brasil, eles são muito mais bem estruturados. A gente aqui em Ribeirão tem uma boa infraestrutura, dependendo do lugar que você visita no exterior, às vezes não muda muita coisa. A diferença está no aproveitamento dessa infraestrutura, lá eles sabem aproveitar muito melhor. Por quê? Porque eles tem dinheiro, fácil, é muito dinheiro e a burocracia é menor, o reagente chega mais rápido. Por exemplo, eu estou com uma infraestrutura muito boa de análise genômica, mas eu tenho que esperar seis meses para chegar os reagentes. No aproveitamento da infraestrutura que você criou, lá eles são muito mais ágeis do que nós. Dinheiro nós temos, um pouco menos do que eles, mas temos o suficiente para ser competitivos. Lá eu testava três perguntas durante um mês - eu fazia uma pergunta e para responder eu comprava o reagente $\mathrm{x}$ e y, aí eu testo; o resultado não foi legal, eu defino o próximo passo, e compro as coisas. Em três meses eu podia fazer três testes de perguntas. Aqui, para eu fazer um teste, eu demoro um ano (Leandro, biólogo, USP/RP).

Nos dois relatos acima, de pesquisadores da USP de Ribeirão Preto - tido, conforme pode ser observado nas falas de acadêmicos de outras localidades nacionais, como um contexto privilegiado em termos de infraestrutura e financiamento de pesquisa no Brasil - a principal diferença, ou o que falta no país, é a agilidade. Os dois pesquisadores destacam que há dinheiro para a pesquisa, e que não há equipamentos ou técnicas que não estejam disponíveis na sua região. Mas isso não significa que a pesquisa possa andar na mesma velocidade que nos centros estadunidenses em que realizaram seus pós-doutorados. Há, inclusive, um exemplo muito contundente dessa percepção de diferença na velocidade da pesquisa, em que nos Estados Unidos era possível realizar três "testes de perguntas" em três meses, enquanto em Ribeirão se demoraria um ano para fazer um único teste. Mais ainda, aparece nessas falas a metáfora de uma corrida, que não pode ser vencida, porque o "aproveitamento da infraestrutura" local esbarra na dificuldade de obtenção de insumos da pesquisa - notadamente reagentes:

Uma coisa que não evoluiu muito no Brasil, é a entrega de produtos. Eu trabalho numa área que é experimental (...), é uma coisa de bancada, então a gente precisa de reagentes, e esses reagentes são na maioria reagentes importados. Então, para você ter uma noção disso que eu estou falando: se você está nos Estados Unidos ou na Europa, você diz: "eu vou fazer um 
experimento hoje, eu preciso desse reagente", não tem na estante, então eu peço; no máximo em dois dias tem uma caixinha na minha bancada. Eu já tive situações aqui de reagentes que demoraram quatro - não dias - meses, para chegar. Como uma pesquisa pode andar num tempo de competição? Porque essa área compete com o mundo, eu não estou competindo só com o Brasil, eu estou competindo com o mundo, porque a ciência é internacional. É o que eu falo para os estudantes: a gente está trabalhando com uma ideia que pode crer que tem alguém, em algum lugar do mundo, trabalhando com a mesma coisa. Então a gente tem que andar rápido. Mas como é que você pode andar rápido com um esquema desse que nós temos aqui no Brasil? (Rafael, biólogo, USP/RP).

O grande problema é que a gente tem excelentes ideias, a gente tem possibilidades tecnológicas para fazer alguma coisa, mas entre conseguir fazer, implantar e ter o resultado, é muito mais demorado do que é no exterior. Por vários motivos: aprovação no comitê de ética, importação de material, sobe dólar, desce dólar... Então às vezes trabalhos de pesquisa extremamente up-to-date no Brasil não conseguem ser publicados na mesma velocidade que seriam no exterior (Gabriela, médica, Unicamp).

Nos Estados Unidos, tu tens uma ideia, tu lê um artigo e pensa "eu poderia fazer uma coisa parecida, aplicar essa mesma metodologia para uma outra situação", alguma coisa desse tipo. Tendo dinheiro, obviamente, tu pegas o telefone, pede um primer para validar uma mutação que você achou, e no outro dia está na tua mesa, no máximo em uma semana. Aqui eu tenho reagentes que estão sendo prometidos para mim há mais de sessenta dias, e sempre vai chegar semana que vem. Essa é a principal diferença. E não é falta de dinheiro. A ciência brasileira está agora mal de dinheiro, mas a gente passou uma época em que a gente ganhou muito dinheiro. A gente tinha dinheiro disponível, as pessoas ganhavam editais, e ainda assim as coisas não andaram em um ritmo alucinante, porque você não consegue comprar as coisas, tudo demora seis meses. Isso faz muita diferença, porque vai te dando um desânimo, até. Tu tens uma ideia legal, tu vai lá, pede, fica esperando, e daqui a pouco tu lês o artigo feito por uma outra pessoa que fez a mesma coisa que tu pensou, mas mais rápido (Thais, bióloga, UFRGS).

É notável a articulação entre uma noção de competição internacional - e de corrida por descobertas e publicação - e a dificuldade percebida devido à demora da importação de insumos de pesquisa. Tal articulação, embora apareça em algumas falas de Porto Alegre, como aparece acima, em que a pesquisadora se vê lendo um artigo publicado por outros, que continha a ideia que estava tentando desenvolver em seu laboratório, é mais frequente entre os pesquisadores entrevistados no estado de São Paulo. Talvez por terem acesso a mais fontes e volume de financiamento - e infraestrutura comparável a centros de pesquisa no exterior que, em princípio, os colocariam em condições de participar dessa corrida, eles destaquem com maior nitidez em que medida os "entraves" percebidos diminuem, na prática, suas chances de vencerem a corrida. 
Alguns entrevistados de São Paulo, inclusive, enfatizaram que, ainda que demore, as condições em que eles importam material são melhores do que aquelas vividas por pesquisadores em outras partes do país:

Eu acho que isso [demora da importação] é um dos grandes entraves que a gente enfrenta no Brasil. É uma demora, mas a gente nem pode reclamar, porque a Fapesp já melhorou muito isso (Luísa, bióloga, Unicamp).

No estado de São Paulo a situação é bem melhor, porque a gente tem a Fapesp, as coisas são importadas pela Fapesp, são extremamente ágeis, mas fora do estado de São Paulo é um problema muito sério conseguir insumos importados. A solução é você comprar no mercado nacional, quando as empresas importam, e aí você paga quatro vezes mais, porque as empresas têm que colocar no preço todo o trabalho que elas têm para importar, os impostos que elas pagam... (Sofia, médica, Unicamp).

Apresentam-se dois cenários diferentes para a importação: comprar diretamente das empresas estrangeiras que produzem os reagentes - via Fapesp - ou comprar no "mercado nacional", de empresas brasileiras que realizam a importação dos produtos e revendem aos pesquisadores, a um custo mais alto que a importação direta. As empresas, ainda que não sejam analisadas detidamente neste trabalho - que enfatizou pesquisadores, professores, pacientes e políticas públicas - são também atores relevantes na produção do conhecimento em genética humana e médica no contexto brasileiro.

Na mesma linha, duas pesquisadoras destacam, também, que estar em Porto Alegre e em Belém, respectivamente, traz dificuldades adicionais no quesito tempo, que pesquisadores mais do "centro do país" não precisam enfrentar, pelo menos não na mesma medida.

Acho que o Brasil avançou bastante, e acho que alguns lugares, o que a gente considera o centro do país, têm mais possibilidades do que a gente. São Paulo, principalmente - um mundo à parte, tem mais recursos, tem mais disponibilidade de coisas e a gente, em outros lugares do país, nem tanto. Saindo um pouco do eixo São Paulo, Rio e Minas, nas outras partes do país a gente tem algumas dificuldades a mais, além de estar no Brasil.

\section{E essas dificuldades a mais são financeiras?}

Tanto financeiras como também de, por exemplo, a gente que trabalha muito com produto importado, demora ainda mais para chegar aqui. Muitos dos nossos equipamentos, se a gente depende de uma assistência técnica, em geral essas empresas são localizadas em São Paulo, e isso significa que estando em São Paulo, o técnico pode ir um dia e voltar e você estando aqui ou em outros lugares do país isso significa uma viagem, então não é de um dia para o outro que tu resolves o problema. A gente enfrenta esses problemas de distância do país, também (Erica, bióloga, UFRGS).

Se você tivesse que comparar um pouco sua experiência como estudante na UFPA e na UNIFESP, você sentia que tinha muita diferença?

Tem! Com certeza! Dinheiro eu não diria tanto, porque houve um tempo em que tinham os incentivos, tinha aquela cota do $\mathrm{CNPq}$, vários projetos foram 
aprovados aqui para o Norte. Era mais em questão de praticidade, por exemplo, fornecedores. Aqui, para alguém te mandar algo novo, saber preço, demora. Não existe a facilidade de enviar, o frete demora. Lá não! Toda semana ia alguém, representante daquela firma x, batendo lá no laboratório, te apresentar as novidades (Bruna, bióloga, UFPA).

Se todos concordam que há "entraves" que atrasam o andamento da pesquisa brasileira, devidos à legislação e à morosidade burocrática e comercial, há também uma percepção que em locais mais periféricos da periferia - em termos geográficos ou simbólicos - os entraves podem ser ainda maiores, como no exemplo de Porto Alegre, em que tanto os insumos quanto o pessoal especializado na manutenção dos equipamentos demoram ainda mais a chegar, ou no exemplo da pesquisadora de Belém, que destaca como em São Paulo, mais do que dinheiro, havia mais "praticidade" para realizar a pesquisa, com contato mais próximo com empresas que vendem os insumos.

Retornando à discussão sobre a competição internacional, uma pesquisadora de Porto Alegre dá o seguinte exemplo, a partir de uma experiência em uma mesa-redonda, em um congresso internacional:

Me convidaram para falar sobre uma pesquisa que a gente tinha feito aqui, que ia ser publicada em uma revista legal. Era o doutorado de uma aluna, que passou três anos se matando para fazer, e eu fui apresentar. Depois de mim veio uma americana falar de um trabalho que ela deve ter feito em um ano, e que era dez vezes melhor. Eu fiquei pensando: "eu morri para fazer isso", e ela vem com fotos muito melhores, ela tinha microscopia confocal, tinha um knockout, tinha não sei o que. Sabe? Tudo que a gente ficou pensando "ah, talvez seja isso, talvez seja aquilo, talvez seja aquilo outro", ela fez. E não tinha "talvez", todos os "talvez" que ela pensou, ela testou. Eu testei uma coisa, e fiquei com cinco dúvidas. E ela disse "testei seis coisas". Até tem outras dúvidas, mas ela fechou o trabalho dela direitinho. O que saí me perguntando era: vale a pena querer competir? Não vale! Porque eu vou ser infeliz, porque não vai dar (Thais, bióloga, UFRGS).

Nessa fala, a mesma ideia da competição aparece, mas já formulada em termos de desistência: uma ideia - não compartilhada por todos os entrevistados - de que as dificuldades são tantas, que não valeria a pena querer realmente competir com pesquisadores em centros mais equipados, mais bem financiados e que, principalmente, têm acesso facilitado aos insumos de pesquisa que, para eles, não são necessariamente "material importado". As dificuldades, como relatado com frequência, dizem respeito ao intervalo - que pode levar meses - entre "ter uma ideia" e testá-la, mas também às novas ideias ou hipóteses que venham a surgir a partir desse primeiro teste, que terão que esperar para serem testadas, ou, no exemplo acima, que ficarão sem ser testadas. Esse processo é descrito por uma outra pesquisadora da seguinte maneira: 
Jamais teremos toda aquela cadeia de causa e consequência, em que um experimento vai respondendo ao outro, que os grandes pesquisadores têm e publicam em grandes periódicos (Ana, médica, UFRGS).

Essa "cadeia de causa e consequência", em que as dúvidas podem ser respondidas rapidamente, é colocada como responsável, ao menos em parte, pela diferença na velocidade em se fazer pesquisa nos centros, e fazer pesquisa nas periferias. $\mathrm{O}$ que justifica, como evidenciado na discussão sobre porque colaborar com o exterior, que pesquisadores brasileiros se desloquem a outros centros de pesquisa para realizar mais rapidamente determinados experimentos, de modo a poder competir, e publicar os resultados mais rapidamente. Como visto, isso significa, também, a inclusão de nomes estrangeiros em um trabalho que poderia ser potencialmente só de um grupo de brasileiros. De toda forma, o problema da demora na chegada dos materiais de pesquisa é tão destacado nas entrevistas, que em quase todas elas há ao menos um relato que exacerba essas dificuldades:

Tivemos agora uma pesquisa em que a gente precisava de um reagente. Nós compramos esse reagente dos Estados Unidos, ele ficou preso na Alfândega por nove meses. Venceu o prazo do projeto e tivemos que devolver o dinheiro, não conseguimos fazer o projeto (Luciano, médico, UFRGS).

Por que uma pesquisa lá sai em 6 meses, e aqui não? Porque lá você pede um reagente e ele chega no dia seguinte no seu laboratório. Aqui eu pedi um reagente em janeiro e ele chegou em julho (Danilo, biólogo, Unicamp).

Em fevereiro do ano passado eu comprei para uma aluna pellets de progesterona, que eram importados. Chegaram semana passada [um ano e meio depois]. Ela tinha que defender o mestrado, defendeu ontem, obviamente sem isso. Tive que mudar completamente o projeto. Eu fiz em Saint Louis o meu doutorado sanduíche, que é a cidade que é a sede da Sigma, então eu fazia os pedidos de manhã, às duas da tarde os reagentes estavam no laboratório (Gustavo, biólogo, UFRGS).

Nos exemplos acima, corriqueiros e múltiplos, tem-se a demora para poder iniciar uma pesquisa, a devolução de um financiamento obtido no CNPq devido a problemas na entrega dos materiais de pesquisa, e uma pesquisa de mestrado que teve de ser toda reformulada, porque o material necessário só foi obtido depois da sua conclusão.

Em uma das entrevistas foi perguntado diretamente sobre a possibilidade de o Brasil produzir os reagentes necessários da pesquisa, de modo a não depender tanto das importações, descritas como muito demoradas:

O tema da importação é muito frequente nas entrevistas, parece ser um grande gargalo. É impossível produzir esses reagentes aqui?

Essa pergunta já foi feita várias vezes por pessoas com formação técnica e científica: "vou produzir aqui no Brasil, em vez de depender do outro para comprar". Acontece o seguinte: as marcas desses produtos são tão grandes, e 
te oferecem um produto tão perfeito, que você fala "pra que eu vou produzir uma coisa, sendo que basta a gente comprar?". Porque não é a minha pesquisa, eu estou fazendo uma pergunta científica, e o produto é um meio para respondê-la (...). Tem uma outra coisa em ciência, na prática da ciência experimental: você, para fazer um projeto científico, você usa reagentes. $E$ tem uma coisa que pesa, também: qual é a marca do reagente que você usou? Usei as lâminas de tal marca, os sais de tal marca. E a comunidade científica já tem repertoriado quais são as marcas de alta confiança. Por exemplo, eu uso um produto de uma marca mundial, ele é distribuído no mundo inteiro e é muito bom. Um pesquisador do Japão tem acesso a essa mesma marca, usa o mesmo produto que uso aqui; usa no Japão, nos Estados Unidos, na Europa. Por exemplo, eu acredito que o Brasil vá fazer um bom produto de biologia molecular, porque nós temos pessoas altamente capacitadas, podemos importar as máquinas e vamos conseguir produzir. Mas qual é o esquema mundial que o Brasil tem para exportar insumos para a pesquisa de biologia molecular e ser respeitado? Então a gente acaba comprando aquilo que o mundo inteiro está comprando. E o mundo inteiro compra de quem? Estados Unidos, Europa ... (Rafael, biólogo, USP/RP).

Evidencia-se um outro elemento, que pode ser pensado em termos de falta de confiança. $\mathrm{O}$ entrevistado afirma que o Brasil poderia produzir um reagente de alta qualidade - a partir da importação dos equipamentos necessários ${ }^{81}$ - mas que dificilmente teria o mesmo nível de reconhecimento do que aqueles produzidos pelas empresas já consolidadas, situadas nos centros. Esse mesmo pesquisador relata que teve um artigo aceito em um uma "revista muito boa", mas que no processo de análise lhe foi exigido repetir o experimento usando o produto de uma marca diferente, pois a empresa que produziu o material inicial tinha sido vistoriada, e havia sido encontrado uma série de irregularidades, e a marca "caiu em desmoralização". O exemplo indica a importância de usar as marcas consolidadas na realização dos experimentos, e que a falta de confiança poderia, então, prejudicar as chances de um pesquisador brasileiro, que tenha utilizado reagentes produzidos no país, de publicar em revistas de prestígio. Ao mesmo tempo, a partir desse exemplo é possível observar que os centros não são simplesmente o local em que o desenvolvimento tecnológico ocorre, mas também os espaços que conseguem definir - ou impor - aquilo que é considerado bom, avançado, aquilo que é confiável e válido naquele momento.

De modo subjacente, tem-se o problema da replicabilidade das pesquisas: nos artigos publicados em genética humana e médica, as seções de materiais e métodos têm descrições detalhadas sobre as marcas e modelos de equipamentos e reagentes, de modo que outro pesquisador possa reproduzir, em princípio, o mesmo experimento. Nesse sentido, produzir reagentes de biologia molecular mas não conseguir exportá-los para outros países, ou, mais

81 A necessidade de importar os equipamentos evidencia que mesmo que os pesquisadores ou empresas brasileiras passassem a produzir os reagentes, o país ainda ficaria dependente da importação. 
precisamente, não haver a possibilidade de a empresa brasileira produzir para o mundo todo e se tornar o padrão mundial, dificulta a replicabilidade das pesquisas.

Para além da demora na importação dos produtos, outros “entraves” são apresentados, como problemas de infraestrutura, tal qual destacado por um pesquisador de Belém, comparando sua experiência atual com o cotidiano de trabalho no Quebec, Canadá, onde desenvolveu seu mestrado:

Quem trabalha com cultura celular tem muito desprendimento da vida. Porque falta luz, os aparelhos queimam porque falta luz, as tuas células morrem. É muito complicado. Nós avançamos muito nos últimos tempos, mas ainda tem algumas coisas que emperram muito o trabalho de quem trabalha com cultura celular. Obviamente não dá nem para comparar a estrutura que eu tinha lá com a que eu tinha aqui (Jessé, biólogo, UFPA).

Aqui eu tenho um freezer, que quando queima eu perco todas as minhas amostras. E lá [França] é centralizado, mas disponível. A gente tem aqui, hoje, um equipamento que é o citômetro de fluxo, que eles tinham um equivalente lá, mas era um único citômetro de fluxo para o prédio inteiro da imunologia, então a pessoa marcava um horário, ia lá, $e$ a técnica de laboratório te auxiliava nos experimentos (...). É um equipamento bastante complexo, que permite a análise célula por célula, e rápido. Nos custou, há dois anos, seiscentos mil dólares. Realmente caro. Qual o limitante disso? No Brasil tu recebes verba com os editais de infraestrutura, tu consegues comprar um equipamento desses, mas tu não tens autorização para contratar técnico. Não tem um técnico dentro da universidade capaz de manipular esse equipamento. São os estudantes que recebem treinamento, de outros estudantes que já trabalharam nisso, e vai passando um para o outro, e quando todos os estudantes terminam a pesquisa, tu ficas com um equipamento de seiscentos mil dólares ocioso (Daniel, biólogo, UFRGS).

Nos exemplos acima há duas questões envolvidas no que se pode denominar infraestrutura de pesquisa. O primeiro, mais amplo, diz respeito à rede elétrica, cuja instabilidade com alguma frequência queima os equipamentos mais sensíveis, e perde-se o material de pesquisa; há outros tantos relatos de amostras que estragaram por problemas semelhantes. O outro, mais específico, das instituições que realizam pesquisa no país, é a dificuldade de se ter técnicos especializados que ajudem a operar e cuidar dos equipamentos, como é destacado no segundo exemplo, em que o equipamento fica a cargo dos estudantes e pode se tornar ocioso caso não haja novos alunos dispostos a aprender a operá-lo ${ }^{82}$. Um pesquisador da UFPA, comparando sua experiência nessa instituição e na USP/RP, faz essa mesma comparação, em termos regionais:

82 Em meu mestrado, cuja pesquisa de campo foi realizada em um centro de pesquisa em genética humana e médica na USP de São Paulo, discuto em detalhes a dinâmica e as implicações desse modelo de divisão interna do trabalho baseado em estudantes, sendo a consequência mais destacada uma certa intermitência das técnicas estabelecidas em laboratórios, que com alguma frequência se perdem, quando uma geração de alunos se renova (Ferreira, 2013, capítulo 4). 
Eles têm um bom suporte técnico. Aqui, em alguns laboratórios acredito que tenha, mas não é a regra. Eu sentia que em Ribeirão era meio que a regra, tinha bons técnicos que faziam essa parte, pelos menos das técnicas mais rotineiras. Aqui não é a experiência mais comum. Então, o que acontece? $O$ laboratório, no dia a dia, é tocado pelos alunos (Jessé, biólogo, UFPA).

No entanto, mais do que problemas pontuais, essas questões são vistas de uma perspectiva mais geral, que, segundo uma pesquisadora, remete à ausência de "contrapartida que a instituição dá para o pesquisador”:

Considerando que os dois locais em que eu estive depois de voltar da Alemanha são laboratórios de ponta aqui no Brasil, com condições que você não acha em qualquer lugar aqui, certo? Então eu estava [pós-doutorado na Unicamp] em um laboratório que tinha dinheiro, todas as condições possíveis que tem o Brasil a gente tinha; tanto lá quanto aqui. Mas tem diferenças, sim, tem muita diferença. Acho que principalmente em questão estrutural das instituições, a contrapartida que a instituição dá para o pesquisador, isso é muito diferente. Aqui a gente tem que se preocupar com muitas questões de organização, se o equipamento está funcionando, se o técnico veio ver, e o técnico daquele equipamento sofisticado não tem no Brasil, a gente tem que mandar importar um técnico para ver se conserta o equipamento, e eu não tenho essa experiência. E essas dificuldades são muito constantes aqui no Brasil, e são muito graves, porque isso prejudica e atrasa muito a pesquisa. Quanto aos equipamentos sofisticados, as técnicas sofisticadas, a gente tem acesso aqui, pelo menos na USP, na Unicamp (...). Não é em todo lugar, mas os centros em que eu estive no Brasil e aonde eu estou agora a gente tem acesso a essas coisas. Mas ai o equipamento quebra porque a rede de energia elétrica não é tão estável, então fica dando pico de energia, e ai queima o equipamento. Esse tipo de coisa você não tinha que lidar na Alemanha. E se tinha, não era o pesquisador que ficava correndo atrás para resolver. Então isso fazia a vida um pouco mais tranquila, as coisas andavam mais fáceis (Isabela, bióloga, USP/RP).

Tem-se a ideia de que "se pede muito do pesquisador brasileiro", sem muitas contrapartidas, enquanto nos centros de pesquisa internacionais visitados, os pesquisadores não precisariam se preocupar em cuidar da manutenção do laboratório e poderiam apenas realizar o seu trabalho:

Eles têm uma equipe muito bem segmentada, tem a pessoa que cuida da compra do material, tem a pessoa que cuida da extração do DNA, a pessoa que cuida de preparar os reagentes para o experimento, tem a pessoa que cuida da parte A do experimento, tem a pessoa que cuida da parte $\mathrm{B}$, tem a pessoa que cuida da $C$, tem a pessoa que cuida da análise, tem a pessoa que cuida da pós-análise, e todo mundo trabalha em equipe (...). Aqui eu tenho que fazer a cotação, tenho que fazer o pedido, tenho que ligar na empresa e cobrar porque o pedido não chegou, eu tenho que ir no banco pagar, tenho que receber o reagente, tenho que coletar o DNA, tenho que fazer a extração, tenho que preparar a vidraria [risos]. Aqui uma pessoa, num doutorado, faz, do começo ao fim, tudo sozinho. Enquanto lá tem uma equipe com 8 pessoas (Danilo, biólogo, Unicamp). 
Por exemplo, quer ver uma diferença brutal? Lá [Inglaterra] o pesquisador ganha o grant, o dinheiro para pesquisa das agências. E não é ele que tem que cuidar do dinheiro, fazer prestação de contas; esse dinheiro entra para uma conta que ele domina, mas ele não vê nada disso, quem vê é um setor inteiro, a pessoa só pede: "eu quero comprar isso, quero usar tal serviço". E aqui, não, aqui a gente ganha o dinheiro do CNPq ou da Capes e eu sou responsável por fazer a compra, por fazer a prestação de contas, por fazer a tomada de preço... Mas eu sou a pesquisadora, e eu vou ter que parar para fazer isso, e eu paro, tenho que parar (...). E isso lá não tem. O pesquisador não perde esse tempo. É uma diferença brutal (Vanessa, bióloga, UFRGS).

A estrutura é diferente entre o exterior e aqui, ainda hoje. Se pede muito do pesquisador brasileiro. Se quer que o pesquisador publique em revistas qualis A, mas não se dá dinheiro para ele e não se dá estrutura funcional, mas se quer que a gente pesquise no mesmo nível de qualidade e quantidade que se faz lá fora. Pouco provável que isso aconteça (Daniel, biólogo, UFRGS).

Nesses casos, destaca-se a falta de infraestrutura de apoio à pesquisa, no sentido de falta de pessoal especializado na utilização e manutenção dos equipamentos, falta de um serviço de secretariado que ficasse encarregado da compra de materiais e no auxílio a prestação de contas, entre outros. Em contrapartida, os centros de pesquisa no exterior são vistos como possuindo uma melhor infraestrutura de apoio e mais possibilidades de se dedicar integralmente a sua pesquisa, o que também lhes dá condições de competição melhores. Em resumo, o "tempo", nos centros, é melhor aproveitado, por que há mais eficiência burocrática e maior divisão do trabalho especializado, ou, em outros termos, uma maior profissionalização, enquanto no Brasil o pesquisador deve incorporar as funções de secretaria, administração, compras e contabilidade de seu projeto, sem necessariamente ter treinamento adequado para tal, o que remete a um certo amadorismo. Comparativamente as experiências no exterior definem-se como mais produtivas para a pesquisa, seja em função da agilidade dos processos, seja porque ali os pesquisadores podem dedicar-se exclusivamente à pesquisa. Reclama-se muito da burocracia brasileira, que dificulta ainda mais esse trabalho, que já conta com pouco apoio institucional:

O que é fundamental atualmente para você realizar a sua pesquisa, em termos de instrumentos, técnicas, bancos de dados, materiais em geral?

$\mathrm{Eu}$ sou extremamente dependente de insumos importados, certo? Então eu acho que se a gente tiver, por exemplo, uma crise de importação, fecha a Anvisa, fecha as importações, isso seria... Assim, eu sou extremamente dependente da globalização [risos], isso em todos os níveis. Eu acho que, na verdade, o que eu diria para você que é a coisa que é mais importante para eu conseguir fazer as minhas pesquisas, é que eu não tenha entraves burocráticos. Acho que o que mais diflficulta é isso, entraves burocráticos nos diferentes aspectos, "isso ficou parado na alfândega", "tem que ir para a CONEP para você poder mandar as suas amostras para o exterior". (...). Isso é o que eu mais tenho que lutar contra (Sofia, médica, Unicamp). 
O que funciona muito bem lá é a parte de secretarias, e essas coisas burocráticas, que para nós aqui é muito pesado, a burocracia para eles é muito mais leve. Por exemplo, para tu comprar um reagente aqui tem que ter três orçamentos, sabe? Tem que fazer três orçamentos, tem que mandar no sistema, dá problema, falta uma vírgula, volta. Lá [Estados Unidos], não, eu dizia o que eu queria, mandava para a secretária do departamento para a secretária me trazer o reagente. Eu não precisava me preocupar com isso.

\section{Se precisava de três orçamentos ou não, o problema não era seu...}

Não era meu, e não precisava. Eles partem do princípio de que todo mundo é honesto, de que se tu está pedindo esse reagente, é porque é esse que tu precisa, não porque tu está favorecendo alguém (Gustavo, biólogo, UFRGS).

De tudo que foi visto até aqui, em suas diversas dimensões, fazer pesquisa no Brasil é fazer pesquisa em um contexto de falta, ainda que de falta relativa, considerando que muitos dos entrevistados destacam que não falta tudo: não necessariamente falta dinheiro ou equipamento, mas falta material de custeio, há "entraves burocráticos", demora, há pouco pessoal de apoio ou infraestrutura institucional para que um pesquisador possa trabalhar sem se preocupar com cada etapa necessária para a realização de uma pesquisa, da tomada de preços à prestação de contas, passando por avaliação no Conselho de Ética, dificuldades de importação, produtos parados na Alfândega e freezers queimados por picos de energia.

Mas a análise da periferia pensada em termos de falta pode ser melhor compreendida a partir da fala abaixo, de uma pesquisadora discutindo uma falta de "racionalidade" na compra e utilização dos equipamentos em seu contexto de trabalho, se comparado à experiência vivida em seu pós-doutorado na Inglaterra:

Uma outra coisa muito legal que eu vi lá [na Inglaterra] era a racionalização dos recursos. Por exemplo, era um prédio grande, mas os equipamentos mais caros eram super racionalizados, eles estavam em salas que eram de uso comum, tinha cadernos para agendamento, as pessoas agendavam e cumpriam rigorosamente os horários agendados. Quando voltei, eu me lembro que uma das coisas que mais me espantou era o número de máquinas de PCR que a gente tinha aqui, em comparação com o que a gente tinha lá. A gente tinha um número muito inferior de máquinas de PCR lá. A gente tinha muito menos máquinas lá do que aqui. Só que as máquinas eram mais utilizadas, e havia uma disciplina muito forte na utilização (...). Não tinha a duplicação que a gente tem aqui (Natalia, bióloga, Unicamp).

Mais do que a discussão sobre uma falta de racionalidade, está presente nessa fala uma dimensão importante, que fortalece a construção de que a periferia é sempre analisada em termos de falta: mesmo quando o contexto local parece ter uma vantagem face ao centro visitado, nesse caso, uma maior quantidade de equipamentos, isso também é construído enquanto falta, são equipamentos demais, há “duplicação”, falta racionalidade.

Quanto a recursos materiais, então, tem-se uma situação que destoa da "racionalidade" 
dos países centrais, e que não se refere propriamente a falta de recursos (embora isso oscile conjunturalmente, como indicam várias falas), mas à falta de eficiência no uso dos recursos que remete, no limite, à irracionalidade: instrumentos caros e ociosos (seja porque não se pode contratar técnicos, seja porque os insumos para a pesquisa não chegam ao país em tempo hábil, seja porque há financiamento para dispor de instrumentos, mas não para comprar os insumos), e pesquisadores especializados, com mestrado, doutorado e pós-doutorado, realizando serviços contábeis. Nesse sentido, as falas acimas apontam para o que podem ser consideradas falhas na própria profissionalização da atividade científica.

Outra dimensão a que a ideia da periferia como falta se refere é a dimensão propriamente intelectual ou científica. O centro é descrito como efervescente e concentrado:

E lá [pós-doutorado nos Estados Unidos] eu tinha tudo muito agrupado e o Memorial, a exemplo de outros centros grandes, tinha a grande vantagem de ter uma concentração de massa crítica, uma concentração de equipamentos, de gente, de estudantes, o que facilita muito a troca (...). Era muito diferente. Eu acho que tem a questão da massa crítica. Você tem uma densidade de discussão maior. Essa é uma questão muito importante. Eram vinte pósdoutores. Vinte pós-doutores muito selecionados. Então tinha uma competição muito grande para conseguir os melhores laboratórios. É a massa crítica, a discussão científica propriamente dita (Diego, médico, USP/RP).

Os centros aparecem como um espaço em que se constata uma maior "densidade": maior quantidade de pesquisadores trabalhando juntos, maior quantidade de recursos para pesquisa - e recursos concentrados - discussões mais profundas e, também, mais competição. De um lado, há um destaque para a quantidade de pesquisadores em que você consegue dialogar, nos centros, que o pesquisador acima chama de "massa crítica", e, no exemplo abaixo, é discutido em termos de "material humano".

E na Espanha, por exemplo, o que tinha talvez de mais importante era material humano. O material humano é extremamente importante, porque lá o [pesquisador espanhol] funcionava como captador central, e em volta dele havia mais ou menos cinquenta pós-docs que trabalhavam em diferentes áreas, desde câncer, até esquizofrenia, enfim diferentes áreas. (...) Então ele captava diferentes áreas de conhecimento e trabalhava muito bem com elas, porque ele tinha um material humano muito bom para trabalhar. Aqui temos efetivamente, fora o pessoal da pós, uns sete professores. Enquanto lá ele teria mais de 50 profissionais, de diferentes áreas (Carlos, biólogo, UFPA).

A comparação evidencia o que é percebido como uma grande assimetria: o instituto visitado na Espanha era dotado de uma equipe interdisciplinar de cinquenta pessoas trabalhando juntas, ainda que em áreas diferentes, enquanto em seu contexto local há um grupo de sete pesquisadores - o que já é muito em se tratando de dinâmica do campo nacional, como visto no capítulo anterior, em que a maior parte das instituições conta com no 
máximo três pesquisadores da área analisada. Esse mesmo pesquisador, ao realizar a comparação em termos de regiões brasileiras, identifica a mesma assimetria:

O Brasil, como te disse, tem uma escala clara entre as regiões... Comparar o Norte com o Sul e Sudeste, em termos de infraestrutura, em termos de material humano, nós perdemos. (...) O Sul e o Sudeste têm uma história grande na pesquisa. Nós estamos construindo a nossa história. (...) há um vácuo, no Norte e Nordeste em termos de pesquisa, vácuo no sentido de número de gente trabalhando. Talvez a nossa maior dificuldade seja material humano, precisamos aumentar a quantidade de gente trabalhando nessas áreas (Carlos, biólogo, UFPA).

Em outro exemplo, uma pesquisadora de Ribeirão Preto, relatando o cotidiano de sua experiência de pós-doutorado nos Estados Unidos, afirma que não acredita que a diferença esteja apenas no número de pesquisadores:

A gente tinha reuniões regulares, com todo grupo, e eu tinha algumas reuniões em que eu fazia a orientação dos alunos de doutorado. Além disso, a gente tinha outras reuniões científicas, aí já fora do grupo, por exemplo uma reunião semanal que envolvia todos os pesquisadores e laboratórios da universidade que tinham aquele objetivo em comum. Por exemplo, tinha o pessoal que trabalhava com vias de sinalização oncogênica, então tinham esses seminários, essas reuniões, em que todas as pessoas - alunos de doutorado, pós-doutorado, pesquisadores juniores - mostravam seu trabalho e era o momento de discussão, em uma rede de colaboração muito maior, que ia além do grupo em que a gente trabalhava, era uma expansão dessas colaborações. Essa é uma característica bastante marcante desses grupos no exterior: você ter uma rede de interação com outros grupos muito maior e ter um momento específico para isso, que era nesses seminários.

Talvez uma diferença seja então a quantidade de pessoas trabalhando em um mesmo assunto. Imagino que seja mais fácil montar uma rede de colaboração quando tem muitas pessoas trabalhando em coisas próximas?

Sim, esse, sem dúvida, é um dos motivos. Mas eu acho que tem um motivo além, que não é falado abertamente, não que seja segredo, nada disso, talvez seja até algo cultural, dessas instituições mais tradicionais, de manter esses grupos de pesquisa um pouco mais alinhados. Porque se nós compararmos com o que a gente tem hoje aqui na Faculdade de Medicina, nós temos grandes grupos e que têm, sim, assuntos correlatos, mas é muito mais difícil você ver essa interação direta, rotineiramente (Carolina, bióloga, USP/RP).

Nas falas até aqui nota-se o destaque conferido à concentração de pessoas e recursos em um mesmo local. Mas, no relato acima, é destacada uma camada adicional, a saber, a falta de interação regular no contexto local. Nos centros há uma quantidade maior de pesquisadores trabalhando em um mesmo tema, e agrupados em uma mesma instituição, e esses pesquisadores são vistos como mais integrados, ou "alinhados". Face a uma periferia percebida como tendo menos "material humano", sendo menos integrada, onde há menos seminários e menos discussões internas. Uma menor integração é identificada na UFPA, se comparada à USP/RP, como pode ser visto abaixo, quando o entrevistado identifica o contexto 
de pesquisa da USP/RP como sendo mais coeso, em que a pós-graduação está mais institucionalizada, e em que os alunos se reconhecem fazendo parte de um mesmo grupo, em comparação a redes mais "frouxas”, identificadas na UFPA.

Em Ribeirão Preto existe uma cultura de pós-graduação que nós não temos aqui. A cultura de pós-graduação é que tenha a pós-graduação, tem o prédio da pós-graduação, tem a secretaria da pós-graduação, quando tem defesa de um aluno o auditório lota, tem uma rede muito mais coesa. Aqui em Belém, a rede não é coesa, ela é mais frouxa. Lá a gente se sente fazendo um curso de pós-graduação, aqui esse sentimento é menor. (...) as redes são menos coesas, se você tem, por exemplo, a defesa de um aluno tu não tem aquela presença em massa, como tem em Ribeirão (Jessé, biólogo, UFPA).

Ainda no âmbito desse mesmo tema, a fala do pesquisador abaixo, cujo doutorado sanduíche foi realizado em uma instituição estadunidense, coloca mais um elemento nessa comparação entre o trabalho realizado no Brasil e nos centros de pesquisa:

Nos Estados Unidos as coisas andam muito mais rápido. (...) Vou dar um
exemplo: a gente estava analisando um microarranjo das aortas dos animais,
e a gente viu que uma série de genes, que eram do sistema complemento,
que é do sistema imune, estavam alterados, ao que a minha chefe me pegou
pelo braço, na hora, subiu ao andar de cima, onde tinha um cara da
imunologia, ele tinha todos os animais knockouts para cada um dos genes do
sistema imune, e ele começou a oferecer [os animais]. Aqui no Brasil, acho
que como a gente tem muita função, além de ser pesquisador, tu é
pesquisador, tu é professor, tu tem que receber alunos de diferentes áreas, a
gente não tem às vezes um foco tão grande num ponto especifico. Lá ela
sabia que se aparecer qualquer alteração em termos de sistema imune,
alguém do departamento de imunologia ia ter tudo o que a gente precisa. Aí
a coisa anda muito mais rápido (Gustavo, biólogo, UFRGS).

Além da maior quantidade, concentração e integração, há também mais especialização entre os pesquisadores dos centros, que, sem precisarem realizar todas as atividades exigidas do pesquisador brasileiro - notadamente as tarefas burocráticas, bem como, nesse exemplo, a carga docente - pode se especializar mais em um "ponto específico". Faltaria, então, maior especialização às periferias, no âmbito específico da produção do conhecimento científico, para além das limitações descritas acima, em termos de falta de profissionalização.

Os centros são também percebidos como espaços em que há diversos seminários, pesquisadores de renome, e um cotidiano permeado por ciência. Tanto é que uma pesquisadora, que realizou seu pós-doutorado nos Estados Unidos, descreve a sua experiência em termos de "choque cultural".

É um choque cultural. O chefe do departamento de genética de onde eu fiz o meu primeiro pós-doc [Estados Unidos], era uma pessoa muito reconhecida porque ele que tinha descoberto o primeiro RNA longo não codificador da inativação do cromossomo X. Era uma contribuição muito importante na ciência, a descoberta do XIST. E eu estava lá no departamento de genética 
nesta época em que tinha o Projeto Genoma Humano no auge. Então era só ciência o tempo todo, então foi uma época... O duro foi a volta, realmente a volta foi crise total [risos].

Você comentou de um choque cultural. O que você quer dizer com isso?

De tudo. Da quantidade de informação e de informações diferentes. Você estar numa cantina, você vê o fulano discutindo genética humana, a quantidade de informação em qualquer lugar que a gente ia... Nos seminários, na hora do almoço, sempre alguma palestra. Era uma informação por osmose, sabe? Ou seja, o tempo todo você fica ligada naquilo que está acontecendo. Saber que a ciência estava nesse nível... A gente aqui fazia coisas muito mais simples (Amanda, bióloga, USP/RP).

Os centros aparecem como o local em que são de fato realizadas as descobertas, onde estão os nomes importantes que realizaram essas descobertas, o local em que a ciência está na "ponta" e em que se vive a ciência o tempo todo, em comparação ao contexto local de pesquisa, em que se realizava, no momento de seu doutorado, "coisas muito mais simples". Essa forte adesão ao que seria o ambiente efervescente dos centros pode ser ponderada, a partir das duas falas abaixo, de pesquisadoras da UFRGS:

No Canadá, e mesmo na Inglaterra, a ciência é uma profissão como qualquer outra. Não estou dizendo que aqui não seja, mas aqui a gente ainda tem, ou tem mais, essa paixão pela ciência, por descobrir coisas, uma coisa ainda romântica, em algum sentido. Enquanto que nos outros países têm a competição, os rankings, tão importantes (aqui também é!), aqui tem uma ideia de ciência que tem a ver com o prazer da descoberta, de fazer uma coisa importante pelos outros, ou pelo país, sabe? Não é que lá não tenha emoção, mas é de outro tipo. Lá tem um tipo de competição muito mais acirrada entre os grupos do que aqui (...).

Você acha que a "emoção" no Canadá e na Inglaterra se dá mais nessa dimensão da competição, da corrida?

Sim. Acho que existe uma verdade nisso, porque quando os pesquisadores externos vêm ao Brasil, eles têm um certo fascínio. Uma pesquisadora canadense, de uma das colaborações que fiz, veio uma vez para cá, e quando foi embora quase chorou de saudades [risos], dizendo "aqui é tão diferente, é tão legal". Aqui você sai para almoçar, não para conversar coisas que tem que ser conversadas, a gente sai, conversa, toma cerveja etc. Existe ainda uma amizade, uma coisa mais leve, é difícil definir (Rita, médica, UFRGS).

Outra coisa que notei que é diferente, é que as relações deles [na Inglaterra] é mais de business, entre pesquisadores. Aqui a gente forma um grupo de amigos, os meus colegas de trabalho são meus amigos. Lá não, a impressão que eu tinha é que se conversava com um pesquisador só coisas relacionadas à pesquisa, era uma chatice. Se alguém te convidava para almoçar você já sabia que era para conversar de trabalho. Eu não queria conversar só sobre isso, queria falar de outras coisas (Vanessa, bióloga, UFRGS).

Nesse sentido, se para alguns dos entrevistados os centros são espaços em que se vive a ciência o tempo todo, em uma efervescência científica estimulante, que faz falta nos ambientes locais, outros percebem essa efervescência enquanto expressão de um nível muito 
alto de competitividade, correlato a um ritmo de trabalho constante e intenso, em que não é possível fazer outra coisa que não seja trabalhar. Assim, alguns pesquisadores destacam que se de um lado seu contexto local é de menor competição, de outro, isso propicia um ambiente de trabalho percebido como mais leve.

Pesquisadores mais seniores, ao realizar a comparação de suas experiências de formação no exterior e no Brasil, destacam, também, o acesso a uma maior quantidade de informação, por meio das bibliotecas, com mais periódicos, que chegavam mais rapidamente do que no Brasil. Nesse sentido, o acesso ao conhecimento era facilitado ao se realizar um estágio fora do país.

Eles [instituição alemã] tinham uma biblioteca muito boa, estava iniciando o Current Content em $\mathrm{CD}$, eles recebiam os $\mathrm{CDs}$ e eu ia à biblioteca. Minha sexta à tarde e à noite era dedicada à revisão bibliográfica: olhava os periódicos um a um, xerocava, e ficava no laboratório lendo. Voltei com uma mala de xerox. Não ia conseguir aqui os artigos (Lucas, biólogo, UFPA).

Ou como relata uma pesquisadora de Porto Alegre que o mais interessante de um estágio curto que fez na Inglaterra, durante o mestrado, foi ter acesso a uma literatura não disponível tão facilmente em seu contexto local, o que já não era importante durante seu estágio doutoral, em que os artigos já estavam disponíveis na internet.

Em termos de literatura científica, o que era importante? Como você fazia sua revisão bibliográfica para o doutorado?

A gente já tinha internet [risos], já tinha pubmed. Eu me lembro, no meu mestrado, eu fiz um estágio em Londres, e o que eu mais gostei de ter ido para Londres foi pegar vários artigos que a gente não tinha acesso aqui. E isso mudou muito de 1994, 1995, quando fiz meu mestrado, para 1998, 1999, quando fiz meu doutorado, aí a gente realmente tinha acesso a essas revistas online (Thais, bióloga, UFRGS).

Ao ser perguntada sobre a experiência em um pós-doutorado no Canadá, na década de 1990, uma pesquisadora de Porto Alegre afirma:

\section{E naquela época, as instalações, os recursos eram muito diferentes?}

Sim. Vamos pensar em coisas que eram muito diferentes. Uma coisa que fez muita diferença para o Brasil foi o periódicos Capes, e naquela época, eu não me lembro se já existia o periódicos Capes ou não, mas se existia ele era muito rudimentar (...); então o acesso à informação disponível em periódicos era muito diferente no primeiro mundo e aqui - se chamava de primeiro mundo. Então havia uma assimetria no acesso ao conhecimento que agora a gente já não tem mais (Rita, médica, UFRGS).

Nesse sentido, a assimetria no acesso ao conhecimento é percebida como de alguma forma superada, primeiro, com o advento da internet e, segundo, com uma política de financiar o acesso a revistas internacionais, conhecido como "Periódicos Capes". Livros e 
artigos, diferentemente de reagentes, deixam de ser material de pesquisa que precisa ser importado. Nesse caso, uma "demora" existente, a demora para ter acesso às novidades, às revistas, às descobertas, pôde ser superada:

A grande revolução que ajudou os países do terceiro mundo foi: primeiro, a internet. Antes, para a gente ter notícias de uma investigação determinada levava três meses para chegar a revista impressa aqui, agora, através da internet, a gente tem acesso à informação na hora, então isso nos coloca lado a lado com nossos colegas do primeiro mundo (Joaquim, biólogo, UFRGS).

Pesquisadores do estado de São Paulo, e entrevistados de Belém, que realizaram doutorado ou pós-doutorado em São Paulo, relatam que suas bibliotecas eram bem equipadas, ainda que o processo de revisão fosse trabalhoso e por vezes demorado. A título de exemplo, tem-se a descrição de um pesquisador de Belém que realizou seu doutorado na USP de Ribeirão Preto:

As bibliotecas da USP eram muito boas, tinham disponíveis uma boa parte dos periódicos que a gente costumava consultar, mais importantes para a nossa área, mas não é o que a gente tem hoje, ou o que eu já fui ter em Oxford, que era a disponibilidade online de todos os papers. Hoje é outro mundo. Naquela época se não tinha o artigo na biblioteca tinha que pedir na Bireme, que era a biblioteca regional da Medicina, para eles conseguirem o artigo, mandar, e chegar em dias ou às vezes semanas a cópia, o xerox. E isso a gente não tinha em Belém, era muita dificuldade para ter acesso. Mesmo em papel Ribeirão Preto já tinha acesso a muita coisa, em Belém, não, era muito mais difícil (Matheus, médico, UFPA).

Outros pesquisadores de Belém relatam a dificuldade de obter os artigos, e alguns de Porto Alegre também, cuja biblioteca não era considerada tão boa nesse quesito, e os artigos tinham que vir todos de São Paulo ou Rio de Janeiro. Constata-se, de novo, assimetrias regionais, dessa vez na disponibilidade do conhecimento.

Ao mesmo tempo, em um momento mais contemporâneo, um dos principais destaques para a experiência de pós-doutorado nos Estados Unidos, e que faz parte do que foi chamado de "choque cultural", era a possibilidade de ter acesso direto ao conhecimento, para além da sua disponibilização em periódicos:

Lá não ficava só nos livros, nas revistas, lendo o que estava sendo descoberto. Se eu quisesse era só ir no laboratório do lado, aquilo que eu via num artigo, eu podia conhecer. Ou aquilo que eu ficava sempre, aqui no Brasil, só vendo na revista, na hora do almoço eu assistia um seminário e via a pessoa relatando aquela descoberta (Amanda, bióloga, USP/RP).

A descrição mais frequente remete a um clima de imersão, que ganha materialidade no acesso a informações, como descrito acima, mas que é mais do que isso: trata-se de um contato com um clima efervescente de pesquisa. Mais do que ler ao mesmo tempo que todos 
um mesmo resultado, a experiência internacional em lugares nos quais se faz "pesquisa de ponta" significa entrar em contato direto com aqueles que realizaram as descobertas e escreveram os artigos nas revistas disponíveis na internet. E tem-se também a ideia de conseguir acesso às pesquisas - e, sobretudo, às novas técnicas, tecnologias e equipamentos antes mesmo de elas serem divulgadas em publicações:

\begin{abstract}
E como você faz para se manter atualizada, ou para buscar novas ideias? Duas coisas: congressos, eventos da área, e depois a gente vai às revistas científicas. Então eu leio o título dos artigos, ou resumos, da maior parte das revistas que são da minha área. Mas é importante ir no congresso, porque na verdade você fica sabendo das coisas antes de elas serem publicadas. Você sabe as tendências, você sabe para onde a sua área está indo. É importante eleger pelo menos um ou dois eventos que sejam importantes na área, e que tenham não só aquilo que é apresentado do ponto de vista de conhecimento, mas também de avanço tecnológico, porque essa é uma área que depende muito de avanços tecnológicos. Então você vai ter, por exemplo, os fabricantes de equipamentos, que vão apresentar as novas técnicas, as novas tecnologias. Eu acho que um pesquisador da área de genética humana e médica que quer se manter atualizado tem que ir obrigatoriamente ao congresso da American Society of Human Genetics, onde você fica sabendo, com anos de antecedência, as tecnologias que vão ser lançadas, para onde a sua área está se movendo (...). Sei que tem muito pesquisador brasileiro que fala "eu gosto de ir no congresso europeu", e é uma bobagem, sabe? Você pode ir no congresso europeu, mas você vai para passear. Aonde as coisas acontecem é no congresso americano (Sofia, médica, Unicamp).
\end{abstract}

O próprio congresso europeu - organizado pela European Society of Human Genetics - se torna, na fala da pesquisadora, periférico (onde as pessoas vão para “passear"), se tomado em relação ao congresso nos EUA - organizado pela American Society of Human Genetics -, no qual "as coisas acontecem". Evidenciam-se, assim, possíveis estratificações percebidas no interior do espaço constituído pelos países considerados centrais para o desenvolvimento da pesquisa na área. Mostra-se, uma vez mais, que é simplificador falar em uma periferia em termos absolutos, uma vez que até mesmo a Europa pode tornar-se, sob certas circunstâncias - nesse caso, o desenvolvimento tecnológico -, subalterna.

No que se refere ao ethos científico dos pesquisadores dos centros, tem-se a percepção é que eles são mais competitivos e, na fala abaixo, vistos como um exemplo a ser seguido:

Eu acho que a competição lá [Estados Unidos] é mais clara. Se fala mais da competição, inclusive. Isso é uma coisa que no Brasil a gente é muito...

\title{
Polido [risos].
}

Muito polido, sim. Existe essa competição: you have to do it! Você tem que fazer aquilo ali porque você tem. No lab meeting às vezes saía um paper de um grupo concorrente, aí o chefe italiano ficava louco, dizia "nós vamos ser roubados, nós vamos ser roubados". Parecia que tinham roubado a casa dele [risos]. Isso aqui é bem menos evidente, a gente ainda não é tão agressivo, a gente precisa ser mais agressivo, realmente (Diego, médico, USP/RP). 
Nesse sentido, os locais em que se faz "pesquisa de ponta" têm pesquisadores mais "agressivos", entendidos como tendo um perfil mais adequado a um ambiente de grande competição pelas descobertas e publicações. A experiência de formação ou pesquisa nesses centros é vista, inclusive, como uma forma de aprender a se encaixar mais nesse perfil:

Você estar em um ambiente em que você sabe que estão os melhores do mundo, vamos dizer assim, é muito estimulante. E te dá perspectiva e ambições grandes, também, e eu acho que isso é importante. Você dizer "eu estou aqui, eu também posso desejar essas coisas, eu também posso vislumbrar coisas como essas para mim e para o meu grupo, para a minha pesquisa". Acho importante você estar exposto a uma situação dessa. A pessoa que não se expõe a essa situação talvez nunca saiba o tanto que é possível fazer, o que é capaz de atingir, porque fica pensando "aqui não é possível, aqui é mais difícil, aqui não dá". E não é verdade, dá para fazer (...). Acho importante você se expor, porque você vê que, no fundo, é todo mundo mais ou menos igual, o importante é você ter uma boa pergunta, independente de onde você está, e você pode ter essas ambições, assim como em lugares mais desenvolvidos, mais ricos (Isabela, bióloga, USP/RP).

Mais do que desenvolver as "ambições" de um pesquisador em contextos centrais, a experiência internacional de formação ou pesquisa é vista, de forma mais ampla, como um aprendizado de como pensar menos perifericamente:

Naquele momento [doutorado-sanduíche na Itália] acho que para mim foi muito importante entrar em contato com a visão que os pesquisadores tinham. (...) Foi a oportunidade de ver como essas pessoas pensavam, como era o delineamento experimental de um projeto (...).

O que é essa visão, exatamente?

Quando você tem uma limitação de recurso, de tecnologia, você tende a trabalhar de acordo com o que é possivel. Então, de certa forma, a gente condiciona o nosso raciocínio, o desenvolvimento dos projetos que a gente faz, de acordo com o ambiente em que está inserido. E a partir do momento em que você sai desse ambiente, você vai ter uma experiência fora, você entra em contato com um centro de referência, que está fazendo o que é possível de ser feito, da melhor forma. Por que? Porque eles têm acesso a recursos financeiros, à tecnologia, a equipamentos. Quando você se depara com esse cenário, que é totalmente favorável, você abre a sua cabeça: como eu desenho um projeto se eu não tenho nenhuma restrição? Acho que é um momento que você fica livre para pensar: se não tem nenhuma restrição, de que maneira essas pessoas fazem ciência? E você percebe que a questão não é só tecnologia, pois ainda que você tenha algumas dificuldades, algumas restrições, já que no nosso país nós não temos o desenvolvimento tecnológico completamente comparável ao que você tinha lá fora (naquela época, hoje em dia a gente avançou muito), você consegue ver que dá para fazer, que dá para desenvolver uma pesquisa, não digo exatamente igual, mas absolutamente comparável, mesmo em um país em desenvolvimento, onde a pesquisa ainda está um passo atrás (Carolina, bióloga, USP/RP).

Há diversos elementos importantes nessa fala, mas destaca-se aqui que ver - na prática - como a pesquisa é realizada por "referências mundiais", como era a elaboração das questões 
e do delineamento experimental de um projeto, como "essas pessoas pensavam" permitiu, segundo a pesquisadora, visualizar como seria uma pesquisa elaborada sem nenhum dos elementos que caracterizam justamente essa periferia pensada em termos de falta. Ir aos centros te "abre a cabeça" para a ideia de que pesquisas "centrais" podem ser realizadas nas periferias, ou, em outros termos, permite pensar de forma menos periférica.

Assim, tem-se a ideia de que uma agenda de pesquisa, elaborada em um cenário percebido como de escassez, é, de alguma forma, influenciada por esse mesmo cenário, que limita o raciocínio, as questões propostas, e, também, o próprio pesquisador. Uma entrevistada nomeia esse processo de "freezer science", ao comparar sua experiência de mestrado na UFPA com a experiência de doutorado na USP.

Costumo dizer que aqui a gente faz muito freezer-science. Você constrói a sua hipótese em torno do que você tem dentro do freezer, das amostras que estão guardadas, resultado de projetos anteriores. Quando você não tem muito dinheiro, você procura ser mais cuidadoso com as suas perguntas, $e$ às vezes até muito conservador com elas, e isso restringe muito o trabalho. (....) mas o argumento, dentro do nosso grupo, sempre foi: se a gente não tem grana, a gente vai fazer o que dá, temos que responder o que a gente consegue. Teve um referee de um artigo que falou: vocês deveriam olhar para mais marcadores. E a gente respondeu: não é uma escolha nossa, se pudéssemos, faríamos todos os marcadores descritos na literatura, mas a gente não tem condições financeiras. Então eu sinto que a questão financeira restringia muito a gente nesse desenho experimental e restringia muito essas hipóteses. Em São Paulo eu sentia que a gente tinha mais liberdade, sim, porque tinha mais dinheiro para gastar. (Monique, bióloga, UFPA).

O exemplo acima mostra que, também em termos regionais, pode-se identificar uma diferença entre desenhar uma pesquisa em contextos de maior abundância econômica - São Paulo - e em contextos mais periféricos - tal como Belém. Consequentemente, torna-se possível pensar em termos de diferenciações quanto ao que deve ou pode ser tornado objeto e problema de pesquisa, de acordo com as possibilidades ou limitações desses diferentes contextos. A constituição de agendas de pesquisa em genética humana e médica, no âmbito brasileiro, será abordada em mais detalhes no próximo capítulo.

Foram descritas, a partir da reunião de uma série de elementos - e relatos - diferentes características da noção apresentada no início desse item, de uma periferia pensada, na comparação com os centros, em termos de falta. O que falta? Faltam o dinheiro, o equipamento, a agilidade (ilustrada pela demora nas importações e pelos entraves burocráticos), o pessoal técnico especializado para a realização de experimentos de rotina nos laboratórios e para a manutenção dos equipamentos. Faltam a rede elétrica estável (para que equipamentos sofisticados não sejam danificados, e problemas com o freezer não destruam as 
amostras), um serviço de secretaria que ajude a gerir o cotidiano da pesquisa - notadamente as compras, manutenção e prestação de contas -, faltam a "massa crítica", o "material humano", uma maior concentração de pesquisadores e expertises, a articulação, a integração, a coesão e a especialização do trabalho. Falta "racionalização" da produção científica. Falta, também, estar em contato com pessoas que realizam a pesquisa de ponta, estar em um ambiente "cultural" efervescente - e competitivo - que incentive pesquisas mais ambiciosas e a participação na corrida pelas descobertas, vista, em geral, como monopólio dos pesquisadores dos centros, os únicos que de fato participam da corrida. Além disso, foi visto que praticamente todos os elementos da periferia pensada em termos de falta são recolocados quando se mobiliza a comparação entre a UFPA, na região Norte do país, e instituições do Sul e, principalmente, do Sudeste: em Belém falta o que os laboratórios do Sul e Sudeste têm: financiamento, infraestrutura de técnicos e secretaria, tradição de pesquisa, um ambiente mais efervescente, uma "cultura de pós-graduação", com maior quantidade de pesquisadores e especialização mais pronunciada.

Esse cenário, conjugado às cinco razões para colaborar com pesquisadores dos centros, apresentadas anteriormente, permite evidenciar cinco dimensões principais da relação entre centros e periferias, identificadas na área de genética humana e médica, que serão explicitadas a partir de agora.

\subsection{Dimensões principais da relação entre centros e periferias}

A primeira dimensão da relação entre centros e periferias reside no reconhecimento de que os centros são locais em que se vai para aprender, locais que ensinam, pois é em seus laboratórios que foram desenvolvidos os principais instrumentos, técnicas e tecnologias de pesquisa. Ao buscar por "aprender" e termos similares nas transcrições das entrevistas, encontra-se quase uma centena de ocorrências, que em sua maioria descrevem a ida ao exterior como "aprender" algo, e "implementar" esse algo no retorno ao país. Por exemplo, um dos pesquisadores entrevistados, que mantém colaboração duradoura com um instituto de pesquisa francês, afirma que o objetivo principal da parceria, sobretudo no seu início, era "transferência de tecnologia", do laboratório francês para o grupo brasileiro:

Eles estavam muito avançados nessa tecnologia, e eu fui aprender isso lá, a tecnologia do transcriptoma, usando uma determinada técnica chamada micro-arrays. Eu fui aprender isso lá, e eles me deram todo o suporte. (...) E nós montamos um laboratório similar ao laboratório que tinha [na França], porém menor, mas com quase os mesmos recursos que eles tinham. E eles 
vinham para cá e ensinavam a gente a trabalhar. E teve uma transferência de know how, mesmo (Rafael, biólogo, USP/RP).

Um pesquisador, que realizou cinco pós-doutorados, diz que seu objetivo ao escolher uma determinada instituição é avançar em sua pesquisa do momento, tendo experiências diferentes e vendo o que pode ser implementado no seu retorno:

Eu achei que era um passo que eu precisava dar, sair e ir para um outro serviço, aprender coisas e trazer de volta. Foi isso que fiz, fui aprender técnicas de diagnósticos (...), fiquei um ano e meio em Londres. Voltei no início de 1987 e desde então eu tenho tentado, mais ou menos a cada três anos, sair, não tanto tempo, mas sair por uns seis meses, aprender coisas novas, trazer de volta (...). Tem duas ideias principais. Uma está ligada ao trabalho de pesquisa que eu estava fazendo na época, alguma coisa que eu pudesse avançar naquele trabalho, uma colaboração mais intensa com um determinado grupo. E a outra é uma coisa um pouco de diversificar experiências, por exemplo, nunca repeti nenhum país. Fui para a Itália, depois para a França, depois para a Suíça, depois para os Estados Unidos, depois Austrália (...). Acho que a gente vendo como é feito nos outros lugares, a gente consegue se apropriar da experiência e ver o que se aplica aqui e tentar sempre melhorar (Luciano, médico, UFRGS).

Em todas essas falas há uma forte ênfase sobre o aprendizado no exterior. Nesse sentido, mais do que estabelecer colaborações - e mesmo publicar artigos - o que aparece em primeiro plano é a noção de que é necessário ir a centros de pesquisa de outros países para aprender, ou que pesquisadores desses centros venham ao país para ensinar. É possível, nessa temática, verificar e destacar uma continuidade com o período de institucionalização, descrito no primeiro capítulo, em que a pesquisa brasileira em genética ganha impulso com a vinda de um geneticista russo, que ensina métodos experimentais em voga e define - em consonância com os pesquisadores brasileiros - uma agenda de pesquisa e um percurso formativo que inclui estadias de pesquisa nos Estados Unidos. Os centros são, então, tanto no processo de institucionalização da pesquisa, quanto no momento contemporâneo, percebidos como lugares que ensinam, enquanto cabe às periferias adquirir esse conhecimento e implementá-lo localmente, quando há estrutura financeira para tal, como pode ser visto na afirmação abaixo:

A minha pesquisa, eu fui estruturando em cima dos meus estudos de pósdoutorado. Primeiro me especializei em genética fetal. Depois fui a Barcelona, onde me especializei em genética reprodutiva (...). Depois de um tempo, resolvi fazer outro pós-doutorado, fui para Londres, quando estava começando a genética molecular, e aprendi lá as técnicas básicas de genética humana molecular, de duas doenças humanas (...), que eu trouxe para cá. Este laboratório foi montado com a minha volta, em 1996, quando comecei a pesquisar bases moleculares de doenças humanas (...). E eu ainda fui para Chicago, trabalhar com uma técnica que chama SNP, com um aparelho que eu não tinha condição de comprar. Os outros que eu fui, eu comprei todos os aparelhos, montei esses laboratórios (Tiago, médico, USP/RP). 
Fica patente a articulação entre aprendizado e implementação, não apenas no sentido de obtenção de novas técnicas e equipamentos, mas no próprio estabelecimento de agendas de pesquisa, a partir da relação com aquilo que estava sendo realizado no exterior em dado momento. No exemplo acima, o processo ir-aprender-voltar-implementar foi interrompido por motivos financeiros - o equipamento era muito caro -, ainda que a ida para os Estados Unidos tenha sido idealizada nas mesmas bases que as anteriores: ir para aprender, comprar os equipamentos e começar a realizar a pesquisa nos moldes em que ela era realizada nos laboratórios visitados. Tal relação entre experiência internacional e estabelecimento de agendas de pesquisas está fortemente explicitada abaixo:

Todas as linhas de pesquisa que eu fui criando ao longo do tempo foram vinculadas à colaboração: eu fui aprender uma coisa nova, voltei, e implantei a nova linha de pesquisa, exceto genética médica, que foi uma expertise mais local, porque a necessidade era local. Cada colaboração, para mim, tem que ser um desafio, para trazer algo diferente, não adianta fazer colaboração para continuar fazendo o que já está sendo feito, isso eu faço sozinho (Lucas, biólogo, UFPA).

Para além da aquisição de conhecimentos especializados em técnicas e ferramentas de análise, e do acesso a determinados equipamentos, a experiência internacional aparece, então, ligada ao estabelecimento de novas questões de pesquisa, de uma agenda criada nos centros, e adotada nas periferias. Tal questão será melhor esmiuçada no próximo capítulo.

De toda forma, para os entrevistados, como pode ser observado nessas falas, o espaço nacional é visto como a arena para a recepção da ciência feita em outro lugar, no "cenário internacional" 83 . Mas o que os entrevistados querem dizer com "internacional" é algo menos amplo do que poderia se pensar à primeira vista: muitos dos que viajaram ao exterior foram para os Estados Unidos, Canadá e alguns países da Europa Ocidental. Nenhum dos respondentes mencionou colaboração específica com uma universidade ou instituto de pesquisa na China, Índia, África, Leste da Europa, e são poucas as menções a relações com países da própria América Latina. O mundo "internacional” para o qual esses cientistas estão orientados é o mundo - bastante limitado e pouco diversificado - central. Nesse sentido, é possível refletir sobre a pertinência da própria ideia de uma "ciência internacional". Tal noção exige um conjunto de características específicas que emergem como resultado da troca entre

83 Uma coletânea de artigos publicada recentemente (Medina, Costa \& Marques, 2014) defende ser necessário ir além da visão da ciência e da tecnologia, na América Latina, como importadas de outro lugar, explorando visões alternativas de como as ideias e tecnologias científicas são criadas, se movem, são alteradas e adaptadas, de modo a enfatizar as limitações das narrativas comuns de difusão. Embora haja cada vez mais críticas às noções de difusão e de que os pesquisadores das periferias são destinatários passivos ou meros reprodutores dos conhecimentos produzidos pelos centros, a ideia de importação - ou "transferência de tecnologia" - está bastante presente nas falas dos entrevistados. 
os diferentes campos científicos (e suas perspectivas correspondentes sobre a atividade científica) e que não podem ser reduzidas à difusão do ideal de ciência de alguns países para o resto do mundo (Medina, 2014). É possível fazer uma extrapolação e dizer que o "internacional", em si, não existe ou, mais precisamente, que ele é percebido enquanto sinônimo de "central". Nessa mesma direção, Connell e Wood (2002), ao discutir elementos do que se convencionou chamar de globalização da ciência, propõem a ideia de quaseglobalização, uma internacionalização confinada ao centros, produzida por uma participação ativa, mas seletiva, dos pesquisadores da periferia.

As duas únicas experiências formativas fora dos Estados Unidos, Canadá e Europa Ocidental são dois estágios doutorais, um em laboratório na Austrália e outro em Israel. Ainda assim, nessas duas experiências, o destaque é para o acesso a técnicas e instrumentos, os laboratórios são considerados como tendo melhor infraestrutura e financiamento para a pesquisa, e a narrativa gira em torno da mesma ideia de aprender e implementar.

Terminei o doutorado em 2001, faz bastante tempo. Era sequenciamento de DNA, PCR e sequenciamento Sanger, isso era o fundamental. E isso eu não conseguia fazer aqui em Porto Alegre, a gente não tinha o equipamento. Então a parte que eu fiz fora foi justamente o sequenciamento e o estudo de expressão para dizer se aquelas alterações eram patogênicas mesmo (...). Eu tinha um conjunto de pacientes já com os DNAs, que eu levei daqui, e analisei lá (...). Mantive um contato [com o laboratório australiano], mas não é uma colaboração que segue, até porque a gente começou a fazer aqui as coisas que a gente fazia lá (Thais, bióloga, UFRGS).

Evidencia-se, assim, um tipo de colaboração muito frequente: colaborar para obter algo que não pode ser feito pelo seu grupo, naquele momento. Nesse sentido, se o pesquisador aprende a realizar a tarefa em questão - ou, no caso, compra os equipamentos - a manutenção da colaboração já não é mais necessária. Nesse sentido, muitas das colaborações internacionais são pontuais, porque têm em seu horizonte a autonomia local. Essa fala também permite delinear uma certa distinção entre aprendizado - ou formação - e uma colaboração. Ainda que muitas vezes, nas falas dos entrevistados, haja pouca separação entre um e outro, é possível diferenciar esses dois elementos e destacar que, mais que uma colaboração internacional duradoura, o que se busca nessas experiências é ter acesso a determinadas técnicas e aprendizado. E, como descrito no item 2.1.2, ter acesso a um ambiente propício ao aprendizado, tido como importante para a posterior padronização de técnicas de pesquisa.

Essa mesma dimensão da relação centro-periferia foi identificada no interior do contexto nacional, em que alguns entrevistados de Belém, na região Norte, que 
desenvolveram seus doutorados ou pós-doutorados no eixo Sul-Sudeste, descrevem praticamente da mesma maneira suas experiências e motivações:

\section{E como foi a decisão de ir para Ribeirão Preto [para o doutorado]?}

A gente tinha que aprender coisas novas, para incrementar as nossas ferramentas para criar ou responder hipóteses. Na época tinha acabado de se descobrir o primeiro termociclador, que ia democratizar a genética, no sentido de que todo mundo poderia fazer DNA. Então a gente dá um passo muito grande, (...) nós decidimos que íamos trabalhar com DNA e que íamos deixar as proteínas um pouco de lado. Na época uma pessoa tinha acabado de chegar da Alemanha, do mestrado dela, e trouxe a técnica para o laboratório [de Ribeirão Preto]. Eu fui para lá, aprendi, trouxe para cá e fiz aqui (Aline, bióloga, UFPA).

Se, para alguns pesquisadores de São Paulo e Porto Alegre, fazer o doutorado ou pósdoutorado no exterior era importante para aprender ou desenvolver uma pesquisa que não era possível de ser feita em seu contexto local naquele momento, para alguns pesquisadores de Belém, laboratórios em São Paulo ou Porto Alegre cumpriram essa mesma função. Nesse sentido, a noção de "centro" remete justamente a uma relação, mais do que uma localização geográfica estática, sendo que as dimensões dessa relação centro-periferia podem ser encontradas no interior de um mesmo país.

A mesma discussão pode ser feita considerando os diferentes países que compõem o "centro". Comentando sobre uma colaboração duradoura com a Universidade do Porto, uma pesquisadora afirma que ela se mostrou muito importante no início de seu trabalho, porque pesquisadores portugueses auxiliaram nos primeiros diagnósticos de pacientes atendidos no Serviço de Genética Médica, e na montagem do laboratório brasileiro: "ele aceitou 60 amostras, uma por família, são 60 famílias, para fazer a investigação, fazer o diagnóstico. Hoje a gente tem 260 famílias, com um monte de pessoas envolvidas, e tudo a gente fez aqui, exceto essas primeiras 60 pessoas". A pesquisadora relata que o pesquisador com quem trabalhava na Universidade do Porto "mandou os estudantes dele se formarem, pessoas brilhantes, três, para a Universidade McGill, em Montreal, para aprender a fazer isso, investigação de sequências repetitivas". Se o "centro" para o Brasil, naquele momento, era Portugal, esse país também tinha seu "centro" no Canadá, onde pesquisadores portugueses foram treinados na utilização de novas técnicas e tecnologias, para implementá-las posteriormente em seu país de origem. E o Brasil, no mesmo exemplo, pode se tornar o “centro" de outros países da América Latina:

Eu acho que é porque eu tenho uma coisa meio nacionalista, mesmo, eu achava que a gente tinha que montar as coisas aqui, tinha que ter autonomia, tinha que colaborar com a construção das competências técnicas locais aqui. 
E foi mais ou menos assim, hoje a gente tem aqui esse laboratório de diagnósticos que há poucos no país, e aí a gente ajuda os outros. Assim como o [pesquisador português] fez conosco, no início, a gente ajuda outros colaboradores pelo país, e fora do país, também. Então a gente tem ajudado muitos médicos peruanos, por exemplo, que não tem essa nossa plataforma de diagnósticos (Ana, médica, UFRGS).

Mais uma vez a ideia de centros e periferias se faz fundamental, considerando que o local em que se vai para aprender não é estático: se um pesquisador de Porto Alegre aprende com um pesquisador sediado na Universidade do Porto, esse último envia seus alunos para realizar estágios na Universidade McGill; se um pesquisador na USP de Ribeirão Preto identifica uma instituição nos Estados Unidos como aquela em que pode avançar na sua pesquisa, com ferramentas não disponíveis em seu laboratório, um pesquisador de Belém descreve exatamente da mesma maneira suas motivações para realizar um doutorado na USP de Ribeirão Preto. As experiências de formação em laboratórios de Israel e Austrália - países que não são considerados pelos entrevistados como estando no topo da produção de conhecimento em genética humana e médica - se configuram nos mesmos termos, como centros de pesquisa que tinham, à época, condições de pesquisa superiores ao contexto local, em que era possível aprender técnicas não disponíveis, para serem implementadas posteriormente. Nesse sentido, as categorias centros e periferias só podem ser entendidas enquanto relacionais, cujo conteúdo empírico só se revela na investigação que se aprofunda em áreas e contextos específicos.

A segunda dimensão das relações entre centros e periferias identificada nesta pesquisa é a articulação que imputa aos centros uma velocidade - ou dinamismo - ausente nas periferias. É nos centros que o desenvolvimento tecnológico ocorre, de maneira acelerada, mas também são os locais visitados quando é necessário realizar etapas de pesquisa de forma mais rápida, quando se quer "acelerar o trabalho". Há, nessa dimensão, dois elementos distintos do que é percebido como uma maior rapidez dos centros: aquele mais característico ao desenvolvimento tecnológico, e aquele mais ligado a questões preponderantemente práticas, como facilidade - e rapidez - na compra de insumos de pesquisa, infraestrutura mais "produtiva" de pesquisa, com mais apoio logístico, serviços de secretariado, compras e prestação de contas, como evidenciado no item 2.2. De toda forma, os centros de pesquisa no exterior são identificados como espaços em que o andamento da pesquisa é mais veloz e dinâmico. Nesse sentido, como visto, a colaboração com o exterior aparece como uma estratégia importante para dar continuidade a uma pesquisa de forma mais rápida, se ela segue caminhos não previstos originalmente: 
Tem coisas que não dá para prever. Você só tem como saber o que vai precisar para iniciar a pesquisa. Durante a pesquisa você sempre vai ter que comprar alguma coisa que não estava prevista, porque vai aparecer um resultado que gerou uma pergunta que exige uma coisa diferente (...). O que essas colaborações permitem hoje para nós? Em geral a gente inicia o projeto aqui, gera os primeiros resultados, e uma maneira de você ser mais rápido na conclusão, principalmente quando aparecem coisas novas, coisas que não estavam previstas, e que se você for fazer aqui, vai levar três meses para chegar o reagente. Essas colaborações aceleram isso. Você pega um aluno e manda para lá e ele vai fazer um experimento que, muitas vezes, você é capaz de fazer aqui, mas até chegar o reagente vai demorar muito; ou um experimento que você não tem no seu laboratório e que não tem em outro laboratório no Brasil, e que mesmo que tenha ele vai ter o mesmo problema que você, da demora (Leandro, biólogo, USP/RP).

Nesse exemplo, a colaboração internacional - mediada por alunos - permite lidar com o problema da demora na importação de insumos necessários para a realização de pesquisas em genética humana e médica. Em vez de esperar para realizar um experimento "que muitas vezes você é capaz de fazer aqui", vai-se a centros de pesquisa no exterior para realizar tal etapa imediatamente. É nesse sentido que é possível pensar em uma dimensão da relação entre centros e periferias, articulada na fala dos pesquisadores, ao identificar os laboratórios que visitam nos Estados Unidos ou na Europa Ocidental como tendo uma infraestrutura de pesquisa veloz - e racional -, enquanto seu contexto de trabalho é descrito como moroso e repleto de entraves de diferentes tipos. As bolsas de pesquisa disponibilizadas por meio da política científica do Brasil permitem fazer determinados experimentos mais rapidamente em outros laboratórios, possibilitando que os centros façam parte da pesquisa periférica. Como contrapartida, os dados podem ser centralizados e armazenados nos centros e pode-se perder parte do reconhecimento por esse trabalho.

Seja como for, a morosidade do contexto periférico é articulada frequentemente quando se discute as colaborações com centros de pesquisa sediados em outros países, ou mesmo em sentido mais amplo, quando se discute as dificuldades de ser conhecido - ou reconhecido - para além de seu contexto local. Em um contexto de grande competição pela prioridade das descobertas a rapidez proporciona, aos centros, vantagens difíceis de serem compensadas pelas periferias. Como visto na seção anterior, essa rapidez é conjugada com a percepção de que os centros são efervescentes, ambientes em que é possível viver a ciência o tempo todo, nas suas velozes transformações, em contraposição a uma imagem mais convencional, e mesmo estática, da produção do conhecimento na periferia.

A terceira dimensão das relações entre centros e periferias incide mais diretamente sobre o tema da infraestrutura de pesquisa e, principalmente, do seu financiamento. 
Relacionado ao terceiro motivo das colaborações - "driblar" a falta de financiamento - tem-se a ideia subjacente de que os centros têm uma maior disponibilidade de recursos para a pesquisa. Nesse caso, se vai aos centros - ou estabelecem-se colaborações - quando não se tem dinheiro para realizar o trabalho localmente, quando não se quer ser "Dom Quixote" e fazer pesquisa dos anos 1990 no século XXI, ou seja, quando em seu contexto local não estão disponíveis os equipamentos, as técnicas e as ferramentas mais modernas para a realização da pesquisa em genética humana e médica, mesmo que, para isso, seja necessário abrir mão de uma certa independência, e, principalmente, de ter aquele trabalho reconhecido como feito integralmente por seu grupo de pesquisa.

Uma quarta dimensão das relações entre centros e periferias pode ser articulada em termos de prestígio e preconceito. Como dito no item sobre as razões que levam os pesquisadores brasileiros a buscar colaborações com seus pares internacionais, há uma percepção quanto a certa dificuldade de publicar um artigo, quando todos os nomes que o assinam são brasileiros. Essa não é uma percepção partilhada por todos, mas aparece com alguma frequência nas entrevistas.

Você já sentiu dificuldade por ser brasileira, para publicar em
determinados periódicos, para ter seu trabalho aceito...? Já senti, sim, claro. Com a experiência tu sabe que tu está sendo prejudicado, porque aquela mesma revista que não aceitou a tua publicação está publicando coisas que são piores, são mais frágeis, às vezes do mesmo assunto, da mesma doença. Tu está vendo, é uma evidência que a tua experiência te mostra, se tu acompanha o tal do periódico. E aquela coisa se repete. Bom, será que acontece com eles também? Não tem como saber se acontece com eles, também, mas só com essa disparidade que tu manda um manuscrito que tu conhece a qualidade dele, e ele foi rejeitado, e a revista publica coisas mais frágeis, com um $\mathrm{N}$ menor, com menor sofisticação, qual é o motivo? Eu acho que não é gênero, porque eles não estão vendo que a gente é mulher, eu acho que a questão é da origem sul-americana. E isso que eu estou te falando é com clareza, porque aconteceu mais de uma vez, e a gente identifica, inclusive, algumas revistas em que isso acontece mais, sabe? (Ana, médica, UFRGS).

O exemplo de um artigo muito parecido que foi publicado em uma revista que recusou seu artigo é o mais recorrente entre aqueles que veem uma dificuldade adicional para se publicar em revistas internacionais prestigiosas, quando sua filiação institucional é brasileira.

Já aconteceu de eu mandar um artigo para uma revista, a revista nem mandar para revisão, devolver o artigo, e uma semana depois um artigo de um outro grupo, um artigo muito similar em tamanho amostral e tudo, mas de um grupo que não era do Brasil, e era de um país, entre aspas, desenvolvido, veio para eu analisar na mesma revista. Esse eu não resisti, eu escrevi para a revista, falei que eram dois pesos e duas medidas. É lógico que eles não reverteram a decisão inicial. Mas eu protestei porque era muito igual. Não dá 
para dizer que nunca teve discriminação. Um pouquinho tem, a gente pode sentir, mas acho que hoje em dia é menos (Gabriela, médica, Unicamp).

Teve uma vez, isso há muito tempo, tinha sido publicado em uma revista, numa American Journal of Human Genetics, que uma determinada mutação não era causa da surdez (...). E eu estudei uma família, e achei essa mutação em dois pacientes. Então eu mandei uma carta para o editor dizendo: "olha, em referência àquele artigo, eles estão equivocados, essa mutação causa a doença sim e aqui está a prova". Não consegui publicar. Acabei publicando isso em uma outra revista, brasileira. Passou algum tempo, alguém publicou isso, exatamente o que eu estava falando, nessa revista e era alguém do primeiro escalão, digamos. Então é óbvio, é evidente, olharam "Brasil" e resolveram que "não, não vamos publicar isso". Eles não chegam nem a mandar para os revisores (Sara, bióloga, Unicamp).

A descrição acima é particularmente interessante, porque se trata de uma carta ${ }^{84} \mathrm{em}$ resposta a um artigo publicado anteriormente, que refuta seu principal achado: determinada mutação na causa da surdez. A entrevistada escreve uma carta para a revista, mostrando que os resultados apresentados estavam incorretos, e apresenta sua própria pesquisa como "prova" de que a mutação em questão causa, sim, surdez. Tal refutação pode ser considerada bastante importante para o desenvolvimento do conhecimento científico sobre aquela doença, mas a revista optou por não publicar o trabalho da pesquisadora. Porém, essa mesma refutação, escrita por um outro grupo de pesquisadores, oriundos de um país com mais reconhecimento simbólico - o "primeiro escalão" - é publicada. A solução encontrada pela pesquisadora, depois da recusa, é publicar seu artigo em uma revista brasileira, cuja circulação é mais restrita, e que terá pouco impacto na comunidade internacional.

Nessa mesma linha, alguns pesquisadores reclamam de um "estereótipo" de que a ciência feita no Brasil - na América Latina, na verdade - não é de qualidade, não é bem-feita. E, também, que a percepção entre seus pares no exterior, que não conhecem grupos de pesquisa no país, é que não há infraestrutura para a realização de pesquisas, não há capacidade local de pesquisa.

A gente é um pouco visto como "ah, latino-americano, a ciência não é bem feita", e a gente tem que mudar isso. Há ainda certa reserva com relação à ciência que é feita na América Latina, esse é um estereótipo que foi criado, e que a gente tem que brigar para mudar (Leandro, biólogo, USP/RP).

\section{Você já sentiu dificuldade por ser brasileira? Em congressos no exterior, ou para publicar um artigo?}

A primeira impressão de quem não te conhece é: "nossa, vocês fazem isso no Brasil?". Entendeu? Existe preconceito. À medida que as pessoas vão te conhecendo, que você vai mostrando o seu trabalho, que você vai frequentando essas reuniões, consórcios, congressos, etc., as pessoas vão

84 Em revistas da área biomédica, esse formato de "carta ao editor", com críticas ou complementos de pesquisas publicadas, é bastante comum. 
vendo que, na verdade, você é tão bom quanto um pesquisador de qualquer outro lugar, na mesma situação. Mas a primeira impressão é "mas tem isso no Brasil?” (Sofia, médica, Unicamp).

Os dois depoimentos acima evidenciam certa percepção de como a ciência brasileira é vista - percebida e reconhecida - no cenário internacional. Ao mesmo tempo, destaca-se que esse "estereótipo" ou "preconceito" pode ser diminuído, conforme se conhece o trabalho e as condições de trabalho dos pesquisadores brasileiros. Nesse sentido, a participação - ativa em congressos internacionais é vista como a ferramenta por excelência para mostrar que se faz, sim, ciência de qualidade no país. Ao mesmo tempo, a entrevistada em questão afirma que muitos pesquisadores brasileiros não se esforçam para mostrar seus trabalhos, ir nos eventos internacionais "botar a cara para bater", o que não ajudaria a diminuir essa visão sobre a ciência nacional:

Acho que tem muito esse sentimento, "ah, é porque eu venho do Brasil". Não é! A gente tem que se expor mais, a gente tem que botar a cara para bater, é assim que eles são conhecidos, é assim que os americanos são conhecidos, é assim que os canadenses são conhecidos, é assim que os alemães são conhecidos. Você tem que ir nos eventos, tem que apresentar, você tem que ser criticado. Uma pessoa vai falar que o seu trabalho está uma porcaria, como eles falam para os americanos também. Mas a pessoa fica "ai, nossa, não gostaram do meu trabalho", "eu não sei falar inglês direito", "então eu não vou mais". Eu acho que o que acontece com o pesquisador do Brasil é esse medo de se expor, de ser criticado, e achar que isso é uma coisa pessoal. Talvez seja a nossa cultura latina, que acha que quando alguém critica o seu trabalho está criticando você. Mas não é, certo? É isso que a gente não pode ter, e esse medo existe (Sofia, médica, Unicamp).

Nesse sentido, a questão de se é mais difícil para um brasileiro conseguir publicar em boas revistas internacionais é colocada em termos de uma dificuldade por ser um pesquisador desconhecido - e não necessariamente por ser um pesquisador advindo da periferia, conforme pode ser visto na primeira fala abaixo. Ao mesmo tempo, outro entrevistado pondera que podem existir dificuldades adicionais por estar situado no país:

Eu acho que importa menos o "ser brasileiro", do que o "quem tu é". Acho que é uma questão mais personalista do que regionalista ou nacionalista. (...) Todas as revistas para as quais eu submeto, todas as revistas que eu já participei como revisor, a revisão é cega só para os autores. Então eu acho que acaba existindo um pouco isso: você vê a lista de autores e o autor principal é um cara que você nunca ouviu falar... (...) Mas eu acho que é mais personalista do que nacionalista a questão (Stefan, biólogo, UFRGS).

Acho que não é exatamente por ser do Brasil, mas acho que quando um artigo é mandado por um pesquisador reconhecido internacionalmente, ele é visto com melhores olhos. Um artigo excelente, mas mandado por uma pessoa desconhecida às vezes... Isso se aplica também ao Brasil. Muitas vezes a gente tem que enfrentar, talvez, um juízo mais criterioso para ter 
uma publicação aceita. (...) principalmente mais no começo da carreira. Eu não diria que isso é diretamente relacionado ao Brasil, eu acho que é mais aos pesquisadores iniciantes de países menos consolidados em termos de ciência. Mesmo um pesquisador emergente, mas em Cambridge, vai receber um olhar diferente de um pesquisador emergente que saiu da UFRGS, esse vai ter que vencer mais barreiras para ter o seu trabalho aceito. Mas, uma vez que se vence essa parte inicial, acho que já somos olhados com outros olhos (Luciano, médico, UFRGS).

Ainda que a principal dificuldade em termos de publicação apareça a partir da distinção entre já ser reconhecido internacionalmente, de um lado, e ser desconhecido internacionalmente, de outro - ou a partir da ideia de que o que conta mais é o "personalismo", e não o "nacionalismo" -, a fala acima aponta que pesquisadores em início de carreira, no Brasil, podem ter dificuldades adicionais para se inserir em boas revistas, sendo mais fácil ser um pesquisador em início de carreira em um centro de pesquisa consolidado, nos centros, do que em laboratórios da periferia. Tentando explicar esse processo, um pesquisador de Belém afirma:

Para publicar um artigo, muitas vezes, precisa ter credibilidade, certo? (...). Não estou dizendo que acontece, mas pode acontecer da pessoa escrever coisas que na verdade não aconteceram. Então, para essas grandes revistas, americanas, ou europeias, revistas que são importantes, elas precisam ter a certificação de que aquilo de fato aconteceu. E como é que acontece essa certificação? Por garantias, ou seja, o cara tem um histórico, ele estudou aquilo por muito tempo. É justo? Não considero justo, porque é como se houvesse uma desconfiança, para pesquisadores novos, ou mesmo pesquisadores de países em desenvolvimento, em desenvolvimento em pesquisa. Então eu acredito que tem um certo grau de desconfiança, mas não é específico por país, é específico por pesquisador.

É mais difícil para um brasileiro adquirir credibilidade do que para um americano, ou você acha que é a mesma coisa?

$\mathrm{Eu}$ acho que é a mesma coisa. Assim, lá, quando ele entra em um grupo de pesquisa ele já entra com pesquisador que já tem um nome, ele já trabalha com as pessoas que já têm credibilidade, então ele publica com o cara, sei lá, os cinco primeiros artigos da vida dele. É mais rápido. De fato é mais rápido. Com certeza é mais rápido (Carlos, biólogo, UFPA).

Nesse sentido, parte da credibilidade - da confiança de que os dados produzidos por uma pesquisa não foram inventados - é dada pelo nome do pesquisador que assina o artigo e, nesse sentido, pesquisadores experientes, que já publicaram outros artigos acerca do mesmo assunto, oferecem mais "garantias" para as revistas de que aquela pesquisa é de boa qualidade. Em pesquisas que exigem a utilização de instrumentação, técnicas e análises sofisticadas, a infraestrutura de pesquisa e o financiamento importam. Essa pesquisa tecnológica necessita de apoio financeiro vultoso e os cientistas e pareceristas dos países centrais sabem disso e, consequentemente, podem suspeitar do trabalho científico realizado 
em países periféricos, considerados, muitas vezes, como não tendo a infraestrutura necessária para realizar tais trabalhos (Traweek, 1992).

Mas, ao mesmo tempo em que se faz esse deslocamento, de que o problema não estaria na "nacionalidade", mas no "personalismo", se reflete que é mais fácil se tornar pessoalmente conhecido se você está em um grupo ou instituição que já conta com grande reconhecimento simbólico. E essas instituições estão nos centros. Mesmo que, como enunciado, alguns pesquisadores brasileiros tenham conseguido vencer as barreiras iniciais de ser novato vindo de um país tido como periférico, esse reconhecimento não se transfere tão facilmente para outros membros de sua instituição, tais como seus alunos. Nesse sentido, os centros podem ser vistos como espaços em que essa transferência de reconhecimento se dá mais facilmente, enquanto nas periferias, cada um dos pesquisadores, individualmente, terá que vencer as barreiras existentes para a publicação científica.

Mas, como dito no início, essa é uma questão que divide muito meus entrevistados, e há aqueles que discordam completamente da ideia de que haveria dificuldades extras em ser um pesquisador situado no Brasil:

Eu acho que os artigos que eu tive rejeitados não foi porque eu era brasileiro, não [risos] (Danilo, biólogo, Unicamp).

Eu não acho, isso eu não acho. Eu acho que às vezes tem um problema de autoavaliação. Quão boa é a pesquisa? (Thais, bióloga, UFRGS).

Tenho várias publicações que eu não coloquei ninguém de fora, porque não tinha ninguém de fora participando. Nunca senti que precisaria colocar um nome para o meu artigo ser aceito. O que sempre senti foi: você tinha uma hipótese clara? A estratégia que utilizou para a tua hipótese era viável? Você conseguiu concluir com aquela estratégia? (Amanda, bióloga, USP/RP).

Vou te dizer que não acredito naquilo que o pessoal fala muito: "quando eu mando meu trabalho para publicar lá fora eles olham que é brasileiro e não gostam, vão recusar o meu trabalho porque eu sou brasileiro". Não acredito nisso. Acho que já passou a fase em que um trabalho era julgado apenas porque vinha do Brasil, e que era considerado a priori ruim. Se vê muito trabalho brasileiro bom publicado em revistas maravilhosas. (...) Claro, tem aquelas coisas. Já tive respostas, às vezes, e, como referee, já dei respostas, também, dizendo que o trabalho estava escrito errado, estava mal escrito em inglês e que deveria ser modificado. Isso sim. (Daniel, biólogo, UFRGS).

Entre aqueles que defendem que não existe nenhuma forma de preconceito ou discriminação, as principais explicações para a recusa de artigos é o domínio do idioma, e não o fato de ser brasileiro. E há, por fim, quem diga que já teve um artigo rejeitado, mas que isso se deve muito mais a dificuldades técnicas e de financiamento: 
Por ser brasileiro, não. Acho que pelas limitações que nós temos, sim. Por exemplo, por mais teste que a gente consiga fazer, tu manda um artigo e volta "gostaríamos que você fizesse o teste tal". Eu não tenho como fazer o teste, não tenho o equipamento, não tenho essa tecnologia toda. Mas um preconceito por ser brasileiro, não. Talvez eles até possam ter, mas eu nunca me senti diretamente lesado por ser brasileiro (Gustavo, biólogo, UFRGS).

Em paralelo à questão do preconceito e à dificuldade de publicar - às vezes resolvida, como visto, via colaboração internacional - alguns pesquisadores destacam a dificuldade de se consolidar enquanto grupo, para além de um reconhecimento internacional individual advindo principalmente das colaborações:

Todos os meus colegas que têm boa inserção internacional são pessoas muito internacionalizadas, mesmo, que ficaram um tempo em laboratórios fora e têm esse livre acesso, têm essa colaboração intensa com outros grupos. Puramente brasileiro é mais difícil (...). Todos os meus colegas que têm pesquisas de inserção internacional forte e reconhecida têm colaborações muito fortes. Não que todos os trabalhos sejam feitos em colaboração, mas são pessoas muito inseridas internacionalmente (Isabela, bióloga, USP/RP).

Embora vista como positiva, a inserção e a colaboração com grupos internacionais pode ter como consequência uma diminuição da autonomia, bem como a menor probabilidade de consolidação de um grupo brasileiro. Quando perguntado sobre o impacto da pesquisa brasileira no cenário internacional, um pesquisador de Ribeirão Preto faz a seguinte reflexão:

Eu acredito que não é irrelevante, não é uma pesquisa que não tem impacto, ela tem. O que falta, talvez, é ter mais recurso para a gente conseguir avançar na investigação para publicar melhor, individualmente. Por exemplo, você virar uma referência só publicando com o Brasil, isso eu já acho mais difícil.

\section{Como assim?}

Um grupo exclusivamente brasileiro publicando e virando referência, sem nenhum cara de fora, sem nenhum parceiro de fora. 'Você pega um artigo que acha legal e vê que é todo mundo do mesmo grupo, isso é legal. Aqui não, os caras importantes são aqueles que estão junto com outros grupos.

Você está dizendo no sentido de que tem um grupo de Harvard que publica um artigo, mas não tem um grupo de Ribeirão Preto, é isso?

É. Não tem o grupo de Ribeirão [ênfase]. Assim, não tem isso de "ele é importante porque é o grupo de Ribeirão", e não porque ele tem relação com o grupo de Harvard, e eles publicam muito juntos e têm parcerias, entendeu? A parceria é muito importante, mas não dá autonomia para virar uma hiper super referência no negócio (Artur, médico, USP/RP).

É o artigo só com brasileiros, ou que ao menos o primeiro e o último autores sejam brasileiros, que contribui alguém a se tornar "referência" no assunto, ou mostra para o mundo que o trabalho foi - e pode - ser realizado no Brasil:

E eu sou um pouco de fazer com que as coisas funcionem no Brasil; apesar das colaborações, eu acho que a gente tem condições de gerar coisas aqui, nossas, made in Brazil, colocar um paper em uma revista de grande impacto com a maioria dos autores brasileiros, ou só brasileiros. Isso é importante, 
mostra que a gente é capaz. A gente é um pouco visto como "ah, latinoamericano, a ciência não é bem feita", e a gente tem que mudar isso.

E nesse sentido o artigo com vários brasileiros tem mais força do que aquele artigo que tem um brasileiro no meio de estrangeiros?

Sim, quando é assim, em geral, é porque a pessoa mandou uma amostra para o cara. Diferente de um artigo do 'grupo de Ribeirão', que tem um colaborador internacional que entrou, mas o primeiro autor e o último autor serem brasileiros faz uma diferença muito grande. Você está entendendo? Porque é isso que mostra que $90 \%$ das coisas foram feitas aqui. (...) Mas está mudando, o Brasil hoje tem publicações de alto impacto só com brasileiros, em boas revistas. Ainda é pequeno isso, se concentra em alguns grupos, alguns centros, mas existe (Leandro, biólogo, USP/RP).

No exemplo acima, tem-se a ideia de que é possível publicar em boas revistas só com nomes brasileiros, ainda que isso seja restrito, segundo o pesquisador, a alguns poucos grupos do país, em genética humana e médica. Mas, mesmo que seja para publicar em revistas piores, há a defesa de que é necessário publicar só com brasileiros, para construir uma autonomia de pesquisa, e um nome, ainda que de circulação restrita, na sua área temática. Perguntada sobre a inserção internacional das pesquisas brasileiras, uma pesquisadora de Porto Alegre responde na seguinte direção:

Pergunta difícil. No que a gente se destaca no cenário internacional? Existem ilhas de excelência no país, não muitas (...). Eu diria que algumas pessoas se destacam, na medida em que elas provam que produzem coisas de forma autônoma. Esse negócio de ficar colaborando, de ficar mandando material continuamente... Tu vê na conformação das publicações, nas coautorias: se nas tuas coautorias tu sempre é o único, ou o segundo, ou o terceiro brasileiro, o resto todo é estrangeiro, todo mundo sabe que tu entrou ali como um pesquisador colateral, não foi o mais importante. Agora, se o grupo todo é de brasileiros, é diferente, ai eles estão vendo que é tu que está produzindo aquele conhecimento, e ai tu é reconhecido, por menor que seja o impacto que o artigo tenha (Ana, médica, UFRGS).

Uma pesquisadora, que define sua posição como minoritária no campo, afirma que mais do que procurar colaborações internacionais, que ela vê como tendência entre seus colegas, o que ela considera que deveria ser feito é "pesquisa de nível internacional”. Nesse sentido, desloca-se, inclusive, a concepção do que seria "internacionalização" da pesquisa: não a busca por colaborações internacionais, mas a realização de pesquisas de "nível internacional", com um grupo de brasileiros - e só brasileiros - publicando no "mesmo nível de um grupo estrangeiro":

[Colaborações] internacionais não tenho experiência, nunca procurei muito, porque eu vejo que os pesquisadores de ponta, quando olham para a gente, é só: me manda as amostras. A gente manda as amostras e fica sendo um exportador de material. Não é um trabalho efetivo. A colaboração é muito direcionada para os interesses deles (...). Não gosto da ideia de ser subalterno a pesquisadores do primeiro mundo. Falam muito aqui em 
internacionalização, mas para mim o maior exemplo de internacionalização é um grupo brasileiro publicando no mesmo nivel de um grupo estrangeiro. Isso é fazer pesquisa de nível internacional, e não estar atrelado a um consórcio, ou ser um entre cinquenta autores (...). Essa é uma posição minoritária, talvez (...). Na área [em que trabalho] a gente está em um consórcio internacional em que tem 30 mil casos e 22 mil controles. Mas o que acontece? Está tudo centralizado [na instituição estadunidense]. As plataformas de análise são de lá, eles têm os dados nos computadores deles. Já mandei para lá uma pós-doc para tentar aprender a mexer nesses dados, mas ela demorou meio ano para conseguir as licenças para acessá-los. Então em um ano que ela ficou lá ela aprendeu muito pouco. Esse é o lado feio da história. O lado bonito, óbvio, é que em estudos feitos com essa quantidade de indivíduos vão aparecer coisas legais, vão ter resultados consistentes. Mas quem está tendo os resultados consistentes são eles. Eles podem colocar o nome da gente no meio do trabalho, mas não foi a gente que fez.

Você disse que sua posição é minoritária. Por quê?

Porque eu acho que a maioria das pessoas fica enlouquecida por esses estudos colaborativos. Elas querem fazer essas colaborações internacionais, querem ter seu nome em um artigo desses, mesmo que lá no meio (...). Eu vejo isso, vou nos congressos e vejo que as pessoas valorizam muito isso. Eu tenho um pé atrás (Débora, bióloga, UFRGS).

Nesse longo trecho está presente justamente as diferenças possíveis na definição do que é "internacionalização", tal como apresentado na introdução. A pesquisadora em questão afirma que os seus colegas chamam de internacionalização a realização de colaborações internacionais, mesmo que isso signifique estar em uma posição subalterna nessa relação. Ela defende um outro sentido para o mesmo termo, que seria fazer ciência "em nível internacional": fortalecer grupos de brasileiros para realizar ciência competitiva, que possa ser publicada nos periódicos mais destacados do campo.

Por fim, a quinta dimensão das relações entre centros e periferias identificada nesta tese é a oposição em que os centros realizariam pesquisas de grande amplitude, comparativas, com maior nível de abstração - seja devido à quantidade e diversidade de amostras que detêm, seja pela densidade da "massa crítica", da quantidade de pesquisadores trabalhando em um mesmo assunto, e da existência de especialização do trabalho mais pronunciada -, enquanto a pesquisa realizada na periferia é local, ou "paroquial". Tal discussão será abordada mais detalhadamente no capítulo seguinte.

O resumo das diferentes motivações para realizar colaborações internacionais, apresentadas pelos pesquisadores entrevistados, e as dimensões das relações centros e periferias identificadas com base nessas motivações, se encontra no quadro abaixo: 
1. Acesso a técnicas, instrumentos e ferramentas de análise $\rightarrow$ No centro se ensina, na periferia se aprende. 2. Maior rapidez no desenvolvimento da pesquisa $\rightarrow \mathrm{O}$ centro é veloz e efervescente, a periferia é morosa. 3."Driblar" a falta de dinheiro $\rightarrow \mathrm{O}$ centro é rico, a periferia é pobre.

4. Facilitar a publicação da pesquisa $\rightarrow \mathrm{O}$ centro tem prestígio, a periferia sofre preconceito.

5. Participação em pesquisa de "grande amplitude" $\rightarrow \mathrm{O}$ centro é universal, a periferia é local.

Este capítulo, a partir da análise das falas dos entrevistados, permitiu desenhar um quadro bem marcado, em que as características dos centros aparecem sempre como positivas, em contraposição a uma periferia pensada em termos de falta. Nesse sentido, ele evidencia a percepção de desigualdades, na visão desses pesquisadores situados em centros de excelência brasileiros, em uma área fomentada pelas políticas científicas, que puderam ser reconstruídas em termos de dimensões das relações entre centros e periferias.

Ao mesmo tempo, retoma-se aqui o achado presente no interlúdio, de que tão somente um quarto de artigos dos pesquisadores se encaixam no que chamei de tipo ideal da divisão desigual do trabalho científico, aquele em que o papel dos pesquisadores brasileiros é restrito, notadamente ao fornecimento de dados sobre a população brasileira, a serem somados e comparados com dados de outras populações, de modo a obter resultados mais generalizáveis, ou com maior grau de abstração. As dimensões das relações entre centros e periferias elencadas neste capítulo permitem, de certo modo, conferir mais materialidade a esse tipo ideal de artigo, mas não esgotam a explicação do cenário mais heterogêneo encontrado na análise dos artigos em coautoria. Se, de um lado, este capítulo permitiu evidenciar diversas assimetrias presentes nas colaborações internacionais, o capítulo seguinte se dedicará a complexificar essa imagem um tanto quanto fixa que foi inicialmente apresentada, acrescentando novas camadas à discussão sobre as relações entre centros e periferias. 


\section{CAPÍTULO 3}

Elementos e constrições da colaboração em pesquisa: aportes envolvendo a articulação e legitimação de uma agenda de pesquisa periférica

Este capítulo avança na compreensão das relações entre centros e periferias a partir do delineamento da construção e legitimação de uma agenda de pesquisa periférica. Como visto no capítulo anterior, entende-se que a configuração entre centros e periferias tem consequências práticas em termos do tipo de pesquisa a ser feita, e, sobretudo, a ser valorizada. Discuto, também, a inserção da pesquisa em genética humana e médica no cenário internacional, notadamente no que diz respeito às articulações discursivas para justificar a agenda e os resultados das pesquisas realizadas no contexto local. O capítulo inicia com a descrição dos motivos que levam pesquisadores dos centros a buscar colaborações com pesquisadores brasileiros da área da genética humana e médica. Partindo dessa discussão, identifica-se a questão do "acesso às amostras" como um tema central para as estratégias de colaboração internacional, para tensões dentro dessas colaborações, para a construção de uma agenda de pesquisa com características específicas e, também, para a justificativa e legitimação da pesquisa no contexto local.

\subsection{Por que é interessante para pesquisadores estrangeiros colaborar com o Brasil?}

Uma das perguntas do questionário dizia respeito à percepção dos motivos que levam pesquisadores do exterior a colaborar ou receber pesquisadores brasileiros em seus laboratórios. Se no capítulo anterior foram explicitados os motivos apresentados para estabelecer uma colaboração internacional por parte dos pesquisadores entrevistados, a partir de agora será discutido o inverso, a importância dessas colaborações para os pares internacionais, segundo, evidentemente, os mesmos pesquisadores brasileiros entrevistados. Essa questão buscou problematizar por que pesquisadores que, em princípio, não compartilham do mesmo status e reconhecimento, ou que não dispõem dos mesmos recursos financeiros e infraestrutura de pesquisa - periferia pensada em termos de falta - se engajam em colaborações. A análise das entrevistas permitiu identificar cinco razões principais que passo a descrever, por ordem de frequência. 


\subsubsection{Acesso às amostras da população brasileira}

A primeira razão, presente em 23 entrevistas, é o que foi codificado como "acesso às amostras". Trata-se, mediante colaboração, de ter acesso a dados da população brasileira, seja de doenças genéticas, no caso dos pesquisadores entrevistados que trabalham com genética médica, seja de populações indígenas ou miscigenadas, no caso daqueles que trabalham com genética de populações ou genética médica populacional.

Esse tipo de colaboração é bastante destacado entre aqueles que pesquisam doenças genéticas raras, em que o número de pacientes com essas doenças é limitado, e a colaboração - internacional ou não - permite aumentar o tamanho amostral das investigações, constituindo, portanto, um aspecto importante para tornar exequíveis ou generalizáveis certos desenhos de pesquisa. Tal questão aparece explicitamente na fala de alguns pesquisadores:

É uma dinâmica para trabalhar com doença rara, que é diferente, porque tem uma barganha, né? "Manda o caso porque isso vai ser importante para o conhecimento sobre a doença e a gente coloca alguém do seu grupo como coautor, manda o manuscrito para você revisar"; porque às vezes o cara só tem isso, aquele caso, às vezes o cara não é um pesquisador, é um médico de um lugar, que publicou isso em uma revista científica, porque é um relato de caso, e é ele que tem acesso àquele paciente. Então a gente recebe muito pedido desse tipo. (...). Só que também ninguém mais está preocupado em mandar mais casos para ninguém, porque todo mundo tem capacidade de investigação, a não ser que você precise de um $N$ grande, por exemplo, que era o caso naquela colaboração, o grupo da Alemanha só tinha casos isolados, eu estava com o único caso de recorrência familiar clara, de pai e duas filhas. A necessidade é a mãe das relações (Artur, médico, USP/RP).

No caso dessa publicação em particular, destacada no trecho acima, mandar o caso brasileiro para os pesquisadores alemães significou entrar na publicação sobre o tema, ainda que o pesquisador em questão seja apenas um em uma longa lista de autores e que, portanto, não trará muito reconhecimento para o seu grupo de pesquisa, que não parece ter participado ativamente da elaboração da publicação. $O$ artigo em questão apresenta algumas das características do tipo ideal da divisão internacional do trabalho científico, descrito no interlúdio da presente tese, porém, como a publicação não tem disponível a descriminação da autoria, não é possível afirmar categoricamente que o pesquisador participou apenas no fornecimento de dados, uma das características do tipo ideal da divisão internacional do trabalho científico, descrito no interlúdio.

De forma similar, um pesquisador de Porto Alegre refere-se a um artigo escrito em parceria com uma pesquisadora situada em uma universidade norte-americana: 
Ela está em um grupo que estuda uma doença muito rara (...), uma doença que tem poucos casos no mundo; no Brasil temos quinze casos, para você ter uma ideia. Ela fez contato com vários grupos, aqui tem pesquisadores da Austrália, da Turquia, dos Estados Unidos, da Europa, da América do Sul. São médicos que já estavam atendendo casos e que avaliaram seus pacientes. Nós avaliamos o nosso aqui em Porto Alegre, o médico lá da Austrália avaliou um paciente em Sidney, daí juntamos os dados e traçamos o perfil dessa doença, mostrando como essa doença evolui clinicamente. Só juntando dados de vários centros que a gente consegue ter um número razoável de pacientes de uma doença tão rara. Então esse é um tipo de trabalho que a gente fez bastante. Como é que foi? A [pesquisadora] desenhou um tipo de protocolo com medidas que a gente tinha que avaliar, observações que tinha que fazer, exames que tinha que fazer, e cada um fez em seus pacientes aqueles exames. Mandamos os resultados para ela e ela fez a compilação desses resultados e produziu uma primeira versão do trabalho que circulou entre todos, cada um revisou e deu suas contribuições, ela recebeu, fez uma segunda versão do artigo, todo mundo olhou, poucas mudanças e então foi para publicação (Luciano, médico, UFRGS).

Nesse relato é possível ver em mais detalhes a importância da colaboração quando se trata de doenças raras, com poucos casos no mundo, em que pacientes de diversos países são reunidos em um mesmo estudo, nesse caso sob a coordenação de uma pesquisadora radicada nos Estados Unidos. Aqui, novamente, a participação brasileira na elaboração do artigo parece ter sido pouco significativa, considerando que há um único pesquisador brasileiro, e seu nome se encontra no meio da lista de autores. Ao mesmo tempo, destaca-se que o trabalho necessário para a realização da pesquisa foi realizado localmente, ainda que os dados tenham sido reunidos e analisados por uma pesquisadora do centro.

Mais do que o acesso a dados de pacientes com doenças raras, há questões ligadas à facilidade de acesso às amostras, dada pela estrutura de organização da pesquisa brasileira em torno do que os pesquisadores constantemente chamam de "ilhas de excelência":

A gente tem muitas amostras, o Brasil é um país muito grande. Se a gente pensar na área de Genética Humana e Médica a gente está pensando numa quantidade de doenças grandes, porque a população é grande, e com setores muito centralizados. Vou te falar especificamente da nossa área (...). Durante muito tempo, o único lugar no Brasil que fazia diagnósticos era Porto Alegre, então ninguém tem a quantidade de pacientes que a gente foi acumulando ao longo dos anos. Agora tem centros em São Paulo que fazem, tem um em Brasília que faz alguma coisa, mas é mais recente. Mas ainda assim, mesmo hoje, tem São Paulo, tem Brasília, e tem Porto Alegre. São três lugares. Se eu faço colaboração com três pessoas eu pego todos os doentes do Brasil. No entanto, se eu for fazer isso na Europa, cada país tem os seus centros, se eu for fazer isso nos Estados Unidos tem dez, vinte centros, mas estão espalhados (Thais, bióloga, UFRGS).

Ou seja, não só a população do Brasil é grande, como os dados sobre ela acabam sendo muito concentrados, em "ilhas de excelência", o que permite certa facilidade no acesso. 
No exemplo acima, a pesquisadora destaca que ao fazer uma colaboração envolvendo um número relativamente baixo de pesquisadores brasileiros é possível ter acesso às amostras de doentes de todo o país. Tal concentração é descrita também na fala abaixo:

A maior parte dos grupos de pesquisa está em hospitais universitários, e os pacientes em geral são muito fiéis aos hospitais, porque eles não têm outra alternativa. Infelizmente. Então quando ele é um paciente de um hospital universitário, ele vai continuar sempre lá, ele é fiel, você consegue fazer estudos prospectivos ${ }^{85}$, que fora do Brasil é muito difícil. Vou te dar um exemplo: o Japão é um país que tem uma população pequena, dentro de uma área pequena, e que tem milhões de centros clínicos; às vezes eles têm três ou quatro hospitais universitários numa cidade pequena, e um fica querendo roubar o paciente do outro. Isso aqui no Brasil não existe, a gente tem paciente de monte (Sofia, médica, Unicamp).

Há, no relato acima, mais um elemento dessa disponibilidade de dados, devido à concentração: como há poucos hospitais universitários que realizam atendimento e pesquisa em doenças genéticas, os pacientes são todos direcionados a eles, e, por falta de alternativa, tais pacientes permanecem fiéis a esse hospital - "infelizmente" -, o que permite a um pesquisador brasileiro que esteja localizado em ou vinculado a um desses hospitais fazer diversas pesquisas, porque os pacientes não desaparecem nem trocam de hospital, como no exemplo do Japão, dado pela pesquisadora.

Além de o Brasil ter uma população grande, certa infraestrutura de pesquisa em "ilhas de excelência", e pacientes fiéis, seu sistema de saúde, apesar de concentrado no que diz respeito às doenças genéticas, tem uma abrangência razoável que permite uma sistematização dos dados que seria impossível em países sem essa estrutura.

Em genética médica temos um grande atrativo, o Brasil é um dos países mais populosos do mundo, claro que a China é mais populosa, a Índia também, mas o Brasil é um dos mais populosos do mundo e tem uma razoável estrutura de saúde. Por exemplo, na Índia não existe sistema de saúde, então é muito mais difícil ter informação sobre número de casos, ter centros que colaboram uns com os outros. A China já tem um número grande de pacientes, tem uma bela organização, mas é mais fechada, é mais fechada para esse tipo de parceria. O Brasil é um país grande e com um sistema de saúde que existe e cobre todo o país e com alguns centros de excelência espalhados pelo país. Então eles veem o Brasil como uma oportunidade de ter uma colaboração com pesquisadores de um país que tem uma certa estrutura científica, porque nós temos ilhas de excelência no país, apesar de nós estarmos bastante atrasados em algumas áreas, nós temos ilhas de excelência em alguns lugares, e temos pessoas qualificadas nesses centros, e temos uma população grande e temos muitos casos. Acho que o grande atrativo é o número de pacientes de uma determinada doença que podem ser estudados; mas não é só isso, se fosse só isso teriam muito mais colaborações com a Índia, com o Paquistão (...). Por exemplo, o Uruguai é

85 Estudos longitudinais, que permitem acompanhar o desenvolvimento de uma dada doença ao longo do tempo. 
um país ótimo, tem centros de pesquisa ótimos, tem pessoas com excelente formação, mas é um país pequeno, não se vai encontrar muitos casos de doenças genéticas raras, então não suscita tanto interesse como um Brasil, Colômbia ou México (Luciano, médico, UFRGS).

Estão presentes aqui algumas comparações entre o Brasil e outros países tidos como periféricos. Assim como o Brasil, a China tem um grande número de pacientes e uma certa infraestrutura de pesquisa, mas é considerada mais "fechada" para colaborações, enquanto o Brasil é visto como mais aberto a esse tipo da parceria ${ }^{86}$. A Índia também tem uma população grande, com muitos doentes, mas com pouca infraestrutura de pesquisa local, o que dificulta a sistematização e centralização desses dados. O Uruguai tem boa infraestrutura e pesquisadores bem formados, mas poucos doentes, então suscita menos interesse dos pesquisadores de outros países. Nesse sentido, o Brasil - assim como o México e a Colômbia - são percebidos como locais mais interessantes para estabelecer colaborações de pesquisa, pois, de um lado, têm condições de mapear as doenças e os doentes, de outro, sua condição periférica faz com que muitas vezes, como discutido no capítulo anterior, a colaboração internacional seja necessária para ter acesso à tecnologia ou financiamento da pesquisa:

Por exemplo, quando você fala "ah, mas na Índia também é assim”. É, só que nós temos infraestrutura muito melhor do que a Índia tem, e até do que na China tem. Em alguns lugares aqui. Então nós somos aquela boa mistura de boa infraestrutura para seguir os pacientes, fazer clínica, mas - como você falou - muitas vezes têm a falta da possibilidade de verba para poder sequenciar cem mil indivíduos. Então eu vou colher os pacientes e mandar para alguém que tem dinheiro, lá fora, sequenciar (Sofia, médica, Unicamp).

$\mathrm{Na}$ fala acima explicita-se bem uma dimensão da relação centro-periferia já tratada no capítulo anterior, em que os pesquisadores da periferia possuem material abundante, mas não necessariamente têm a disponibilidade de técnicas, a agilidade, ou o financiamento para a análise e a publicação dos achados científicos derivados desse material. Nesse sentido, as colaborações internacionais são concebidas enquanto uma troca, em que os diferentes colaboradores têm interesses diferentes, por vezes complementares:

O que mais interessa são os casos raros. Por exemplo, nessa parceria que a gente está tentando com o pesquisador da Dinamarca, ele tem um projeto que está tentando juntar o maior número de pacientes possível com um tipo específico de alteração cromossômica. Está buscando ampliar a casuística

$\overline{86}$ A defesa de que é necessária uma abertura às colaborações internacionais pode ser verificada na fala de um pesquisador da UFRGS: "Porque na genômica (...) o que é fundamental é ter milhares de pacientes, a gente está vivendo uma revolução, hoje, na quantidade de achados genéticos, a partir desse esforço em colaborar, em não querer só olhar para o próprio umbigo, ‘eu vou descobrir tudo aqui sozinho'. Não! Vou disponibilizar as amostras para análises que reúnem milhares de pacientes, milhares de controles. E aí o número de questões de pequisa que se abrem é infinito. (...) não há risco nenhum na internacionalização e união das amostras" (Miguel, médico, UFRGS). Ainda que se apresente uma defesa das colaborações e da "união" de amostras, também sugere-se que há resistências - locais e internacionais - quanto a esse tipo de relação. 
dele. Então se a gente tem a possibilidade de colaborar aumentando a casuística dele, e ele tem a tecnologia para estudar esses pacientes que e a gente não tem, a gente está interessado em aprender essa tecnologia. Ele tem um interesse e a gente tem outro (Danilo, biólogo, Unicamp).

Essa relação de troca, em que pesquisadores dinamarqueses têm "interesse" em "juntar o maior número de pacientes possível", e o pesquisador entrevistado tem "interesse" em aprender com esse grupo a tecnologia, evidencia, mais uma vez, o horizonte de aprendizado que podem ter as colaborações internacionais.

A questão do acesso às amostras aparece em dois sentidos nas entrevistas. Primeiro, como dito, em termos de "quantidade", quantidade de doentes devido ao tamanho da população brasileira e o acesso mais ou menos centralizado a essa população, que facilita a colaboração. Em segundo lugar, tem-se a "qualidade" dessa amostra. Essas duas dimensões estão sintetizadas na fala de uma pesquisadora da Unicamp, quando perguntada sobre por que é interessante para os pesquisadores de outros países colaborarem com seus pares brasileiros:

\begin{abstract}
Simples, sample size. Nós vemos muito o paciente, certo? Todos nós, todos os centros. E outra coisa, nós temos muita variedade, nós temos sample size e a quantidade da genetic variability que a gente tem, certo? A nossa população tem características interessantes. Não só ela é grande - então todo mundo tem um monte de amostra -, como ela tem grande variabilidade, ela é uma população miscigenada, e isso aumenta a sua probabilidade de encontrar coisas que você não encontrou em outras populações, você acrescenta variabilidade genética. (...) Então eles estão interessados em sample size, e na qualidade desse sample size, também, a qualidade da caracterização clínica (Sofia, médica, Unicamp).
\end{abstract}

A população aqui é miscigenada, o que também é coisa boa, é melhor fazer pesquisa no Brasil do que fazer na China, porque a mutação chinesa só chinês tem. Mutação brasileira aparece na África, aparece nos Estados Unidos, aparece na Europa, então é mais rico. Tem umas que só aparecem no Brasil, mas enfim... (Thais, bióloga, UFRGS).

A qualidade pode também ser entendida em três acepções diferentes. De um lado, como explicitado na fala acima, da pesquisadora de Porto Alegre, qualidade no sentido de uma "diversidade". Em virtude de a população brasileira ter "variabilidade genética", há uma maior possibilidade de se deparar com "coisas que você não encontra em outra população" - e então obter achados originais. De outro lado, essa "miscigenação" possibilita que se encontre mutações comuns a outras populações - o que permite a produção de dados mais generalizáveis. A pesquisa nesse sentido enriquece tanto pelo que seria uma dimensão mais singular, quanto pela possibilidade de generalização. Por fim, tem-se a qualidade dos pesquisadores brasileiros em genética médica, a qualidade da caracterização clínica dos 
pacientes: "e uma coisa em que nós somos bons, nós os médicos brasileiros, nós somos bons clínicos, os nossos pacientes são muito bem avaliados (Sofia, médica, Unicamp)”.

Para explicar o interesse dos colaboradores internacionais, o tamanho amostral colaborações que aumentam o "N" das pesquisas - foi mais enfatizado pelos pesquisadores trabalhando com genética médica, e a variabilidade genética da população brasileira foi mais destacada pelos entrevistados em linhas de pesquisa relacionadas à genética de populações ou à genética médica populacional:

O grupo [inglês] trabalhava nessa mesma perspectiva que a gente (...), essa questão da genética médica populacional. Ele tinha colaborações em vários continentes. Porque hemoglobinopatias são doenças que estão no mundo todo, mas têm influências geográficas, étnicas, então há grupos que têm alguns tipos de mutações, outros não têm, e ele trabalhava com essa visão de genética populacional. E quando eu estudei populações indígenas, um dos trabalhos a gente publicou junto com eles, a gente descreveu uma alteração que encontramos em indígenas (...), e eles não tinham acesso a populações indígenas. Eles tinham acesso à África, à Ásia, às ilhas do Pacífico, mas não tinham populações indígenas. Então eles estavam interessados em identificar coisas nas populações daqui (Matheus, médico, UFPA).

Há um elemento bastante importante nessa fala, que é o fato de o laboratório da Inglaterra, mediante colaboração com pesquisadores de países de outras periferias, para além do Brasil, concentrar as amostras de diversos locais. A ida ao laboratório em questão permite que o pesquisador publique um artigo em colaboração com pares ingleses, mas não lhe dá, aparentemente, acesso às amostras disponíveis dos outros países. É possível pensar em uma série de colaborações bilaterais em que os centros se tornam centros de cálculo e pontos de passagem obrigatórios (Latour, 2000; Callon, 1986).

A questão da importância da diversidade das populações e da sua significância para a colaboração internacional também foi muito citada por pesquisadores envolvidos com a pesquisa sobre o câncer gástrico:

No caso desses dois pesquisadores [dos Estados Unidos e da Alemanha], eu não sei se seria o caso de outras colaborações internacionais, eles são pessoas que trabalham com muitos grupos internacionais. Eles fazem pesquisa oncológica. E o câncer no Brasil, como é? Então isso é uma coisa que a gente pode dar de colaboração para eles, dar essas informações do câncer aqui. Fazer um projeto multicêntrico, internacional, e as nossas amostras podem fluir tranquilamente para os Estados Unidos, para a Alemanha, e eles analisarem lá. As amostras daqui são diferentes das de lá, a população daqui é diferente, e aí eles podem fazer essa análise das amostras daqui, com as ferramentas que eles têm lá, que são coisas que nós não faremos aqui. Vai trazer respostas muito boas para os nossos casos. (...) Com as nossas amostras indo para lá, e de outros países também, eles conseguem fazer análises comparativas, que fica um trabalho muito bom, com certeza. Isso é vantajoso para eles, não é? (Samuel, biólogo, UFPA). 
Primeiro, pelo conhecimento, potencialmente pelo conhecimento, e como eu já dizia, por querer colaborar com o mundo todo. (...). Segundo, eles podem ganhar com pesquisa no Brasil, por exemplo, o [pesquisador espanhol] trabalha muito com câncer, mas não trabalha com câncer gástrico, porque a incidência de câncer gástrico na Europa é muito pequena. Ele tinha interesse. Ele também não teria, vamos supor, indígenas, na Europa não vai ter, então também é outra coisa. (...). E o potencial do que a gente está fazendo gerar uma publicação interessante. (Carlos, biólogo, UFPA).

Nessas duas falas está presente, com formulações diferentes, a mesma ideia, a de que a colaboração permite que os pesquisadores dos centros - nesses exemplos, dos Estados Unidos e da Espanha - tenham acesso a amostras não disponíveis de outra maneira, amostras essas que podem complementar e diversificar a pesquisa, permitindo "análises comparativas" que vão gerar "publicações interessantes".

Ainda que menos discutida nas entrevistas, essa disponibilidade brasileira de recursos está permeada por elementos socioeconômicos e políticos. Um pesquisador destaca, por exemplo, nesse mesmo tema, que "câncer de estômago tem muito mais em país pobre do que em país rico, e aí isso desperta também o interesse, porque a gente tem um volume de casos que eles não têm lá" (Pedro, médico, UFPA). Ou seja, há aqui uma dimensão econômica na quantidade de casos de câncer gástrico no Brasil e essa desvantagem pode se tornar uma vantagem na colaboração, porque se trata de um problema pouco comum em outros países, havendo, portanto, muitas amostras disponíveis para a análise no contexto local.

Discutindo um artigo escrito em coautoria internacional, uma pesquisadora destaca outro tipo de vantagem que os pesquisadores brasileiros podem ter:

Esse artigo... Isso entra naquela coisa do porquê o Brasil é interessante, às
vezes, para as pessoas. O Brasil é um lugar onde tem muita cesárea, e a
hipótese do artigo era (...) de que crianças que nascem de cesárea têm mais
chance de serem obesas depois, não logo que nascem, mas mais tarde, e ela
[pesquisadora brasileira] começou a pesquisar sobre isso e viu que tinha uma
pesquisadora na Finlândia, eu acho, que viu que existiam diferenças na
microbiota intestinal entre as crianças que nascem de cesárea e de parto
normal e aí ela resolveu fazer um trabalho sobre isso, e veio falar comigo
(...). Então tinha esse trabalho mostrando que a criança que nasceu de
cesárea tem uma flora diferente porque ela nasceu de cesárea, mas poderia
ser porque a criança teve um problema e por isso teve que nascer de cesárea.
E aqui tem muita criança normal que podia ter nascido de parto vaginal,
mas foi escolhido que fosse cesárea (Thais, bióloga, UFRGS).

Aqui não se trata exatamente de uma característica de um "país pobre", mas de uma prática cultural e econômica ${ }^{87}$. De acordo com pesquisa realizada com dados de 150 países

87 Não há uma única causa para essas altas taxas de cesárea, mas pode-se apontar desde fatores socioculturais, como a noção de que uma cesárea eletiva, decidida com antecedência para dia e hora marcados, permitirá à mulher um parto sem qualquer dor, e fatores econômicos, no sentido de obter maior rentabilidade do parto: além de a maioria dos hospitais privados cobrar mais por uma cesárea, os médicos podem atender a mais 
(Betrán et al., 2016), a média mundial de partos realizados com cesariana é 18,6\%, sendo a América Latina a região em que essa taxa é mais alta (40,5\%), seguida pela América do Norte (32,3\%), Oceania (31,1\%), Europa (25\%), Ásia (19,2\%) e África (7,3\%). Apesar de o aumento na incidência de cesárea ser um fenômeno comum a quase todos os países, o Brasil é o país cuja curva de aumento é mais acentuada e as taxas alcançaram os níveis mais altos: 55.6\% dos partos acontecem dessa forma (Betrán et al., 2016). Se tais dados são vistos com certo alarme do ponto de vista da saúde pública, no caso dessa pesquisa em particular, descrita pela entrevistada, é a característica brasileira que permitiu testar uma hipótese a qual, em países cujo número de cesarianas é relativamente pequeno, não seria possível.

Discussão semelhante é feita por uma pesquisadora da UFRGS:

\begin{abstract}
Nós temos uma população enorme, miscigenada, nós temos muito mais doentes do que eles. Não nasce mais Síndrome de Down na Europa, como é que vai estudar isso lá? Por quê? Porque lá se aborta. Porque lá se aborta, não nasce mais, todo mundo faz diagnóstico pré-natal. E aqui continua, porque o aborto é proibido por essa lei infame que criminaliza as mulheres (...). Eu te dei o exemplo do Down, que é fácil de identificar em uma ecografia. Mas as outras coisas, também, porque a gente tem uma taxa de nascimento elevada, então a gente tem muitos doentes, a gente tem amostras interessantes, misturadas, que interessam a eles. Como eu te disse, para tu identificar se um fator em estudo de fato está vinculado à tua hipótese, tu precisa cotejar com outra população, para ver se não tem isso que eu chamei de estratificação populacional, e é importante ver em outros doentes. Então podem ser brasileiros, podem ser de outras partes do mundo, em geral do mundo mais dependente.
\end{abstract}

Resumindo, um motivo frequentemente destacado para explicar porque são procurados por pares dos centros para realizar colaborações internacionais se relaciona ao interesse desses pesquisadores em ter acesso às amostras da população brasileira, seja do ponto de vista das doenças genéticas, da genética de populações, da genética médica populacional ou da genética do câncer. Foi possível identificar e articular uma série de elementos que fazem dos pesquisadores brasileiros colaboradores interessantes, notadamente do ponto de vista das amostras: o país tem uma grande população - em números absolutos e em número de doentes -; uma população diversa no quesito da variabilidade genética; possui centros de pesquisa - ilhas de excelência - capazes de coletar e armazenar essas amostras, bem como médicos que são "bons clínicos", e que podem atender adequadamente esses pacientes e produzir os dados clínicos necessários para a pesquisa. 
Trata-se, no entanto, de uma configuração paradoxal, em que características pouco vantajosas do ponto de vista do atendimento à saúde - como a quantidade reduzida de hospitais universitários ("ilhas de excelência") e a existência de "pacientes fiéis" (que não têm alternativa, para além do sistema privado ou de saúde suplementar) - e da perspectiva da pesquisa (poucos centros de pesquisa), se convertem em vantagem, do ponto de vista da colaboração com o exterior. Nesse sentido, o que é descrito em termos de facilidade de acesso às amostras de muitos pacientes e concentração dos dados ocorre porque o atendimento - e a pesquisa - em genética médica está disponível em poucas instituições. Do mesmo modo, destaca-se que há uma infraestrutura razoável, mas insuficiente, o que também pressiona os pesquisadores à colaboração. E, por fim, nota-se que desvantagens socioeconômicas, que condicionam a estrutura do sistema de saúde, acabam transformando-se em vantagens, quando se pensa estritamente na feitura de uma colaboração.

\subsubsection{Pesquisadores brasileiros como "mão de obra barata”}

Uma segunda razão para que pesquisadores de outros centros de pesquisa busquem colaborar com pesquisadores brasileiros é o fato de esses últimos poderem ser considerados uma "mão de obra barata". Tal termo, ou ideias correlatas, aparecem em 17 entrevistas e é o segundo motivo mais citado, como pode ser visto nas passagens abaixo.

Bom, acho que há muitas razões. Uma é que historicamente trata-se de mão de obra barata. O que eu quero dizer? Mão de obra barata no sentido de que o Brasil paga, eu fui sempre com bolsa brasileira; (...) imagina que maravilha que é tu ter alguém que vem para o teu laboratório com uma bolsa que não é tua, isso é maravilhoso (Rita, médica, UFRGS).

Um outro ponto que a gente não pode deixar de considerar é que muitos dos pesquisadores daqui que vão para lá - e a gente fala nisso quando a gente conversa com os alunos de doutorado, ou mesmo pós-doutorado - a grande maioria deles inicia essa colaboração com recursos do próprio país. Quando você olha isso de lá, é algo bastante interessante, você fala "opa! Eu vou abrir meu laboratório, eu vou ter uma pessoa muito interessada em se desenvolver, em se capacitar, e é uma mão de obra gratuita" (...). Você recebe uma pessoa, você oferece para ela capacitação, mas ela está ali produzindo e trabalhando para você (Carolina, bióloga, USP/RP).

É possível identificar, aqui, outra dimensão importante da relação centro-periferia: o que os entrevistados descrevem é um processo em que os pesquisadores, com financiamento concedido por agências nacionais de fomento à pesquisa, vão trabalhar, por um período mais ou menos curto, em um laboratório dos centros. Nesse sentido, a "mão de obra barata" - que na verdade é mão de obra gratuita do ponto de vista de quem abre o laboratório - é uma 
espécie de contrapartida das relações descritas no capítulo anterior: vai-se aos centros para aprender e, em troca, trabalha-se para eles. Esse processo está bem descrito abaixo:

Por exemplo, no caso de uma colaboração que fiz com a Suécia, a gente queria estudar algumas mutações identificadas em pacientes aqui no Brasil, que são mutações inéditas, e que a gente tinha interesse em ver a função na enzima. E eles tinham essa técnica montada. O que aconteceu? Quando a gente propôs, eles falaram: "que bom, porque a gente também tem algumas mutações novas aqui e não tem ninguém para fazer". Então receberam a minha aluna, o que para eles era uma vantagem, porque eles não estavam pagando nada para ela, e ela fez, além das nossas mutações, as deles também. Foi um interesse mútuo. Depois publicamos todas as mutações juntas (Manuela, bióloga, Unicamp).

A pesquisadora da Unicamp quer ter acesso a uma determinada técnica de pesquisa e, para isso, envia uma aluna a um laboratório da Suécia, que dispunha da "técnica já montada" - padronizada - para analisar as mutações que seu grupo identificou em um conjunto de pacientes brasileiros. O laboratório em questão recebe sua aluna, com bolsa de agência de fomento brasileira, e a contrapartida é que ela trabalha também com as novas mutações identificadas pelo grupo sueco, que naquele momento não tinha "ninguém" se dedicando a analisar. Logo, nesse tipo de relação é possível enxergar uma certa divisão do trabalho científico, em que os centros entram com a formação e a disponibilização de instrumentos, insumos, e técnicas padronizadas, e os pesquisadores das periferias entram com seu trabalho especializado - que requer a mobilização de competências e de saberes específicos e reconhecidos ${ }^{88}$. Ao mesmo tempo, os pesquisadores entrevistados não consideram que, nessa divisão do trabalho, lhes caiba realizar trabalhos básicos ou indesejados, em benefício dos pesquisadores dos países denominados centrais:

É mão de obra barata [risos]. Olha, nos Estados Unidos, a grande maioria do pessoal dos laboratórios lá não é norte-americana, são tudo de outros países. (...) E com relação a pessoas que não se instalam lá - então fazem estágios temporários - é aquela coisa: sempre é bom ter uma pessoa a mais, especialmente uma pessoa bem preparada, para realizar um tipo de pesquisa determinado. Então se um brasileiro, que teve uma formação adequada no Brasil, resolve ir para os Estados Unidos e depois voltar, ele é bem recebido porque ele vai levar material que não tem lá, vai ter uma nova pessoa trabalhando lá no laboratório, de graça, porque geralmente para esses estágios têm que ter bolsa do Brasil (...). Esses doutorados sanduíche, por exemplo, são um desenvolvimento da nossa ciência que eu considero valioso, porque os alunos vão para lá, desenvolvem uma técnica que não pode ser feita aqui, voltam, e analisam os dados aqui, depois publicam em colaboração. Então é, de novo, o negócio das duas direções, colaboração nas duas direções, é benéfico para eles e para nós (Joaquim, biólogo, UFRGS).

88 Esse tipo de colaboração, tal como exposto no interlúdio, não tem as características do tipo ideal de divisão do trabalho científico, ainda que expresse certas assimetrias. 
É evidenciado, acima, o caráter positivo desse tipo de colaboração, em que os dois lados da relação são beneficiados. Contudo, subjacente à realização dessas atividades, os pesquisadores brasileiros encontram-se diante de certa situação de dependência em relação aos pesquisadores dos laboratórios que possuem a infraestrutura necessária, ou seja, há uma assimetria que marca tais relações. Em outros termos, os cientistas que dispõem dessa infraestrutura podem decidir delegar uma parte das atividades de pesquisa no marco de uma colaboração, enquanto os pesquisadores (brasileiros) que não contam com essas facilidades de acesso devem, necessariamente, colaborar para levar adiante suas pesquisas. A dependência de uma das partes no que diz respeito à colaboração é bem mais importante do que a da outra.

Não se trata de afirmar que essa seja uma relação de pura exploração, considerando que os próprios pesquisadores, como visto anteriormente, descrevem essas viagens como uma oportunidade importante de ter acesso a técnicas, instrumentos e ferramentas de análise, ou mesmo uma maior rapidez na produção de dados, tidos como cruciais para a realização de suas pesquisas. Ao mesmo tempo, é possível dizer que se, de um lado, enfatiza-se a importância do aprendizado nesses centros de pesquisa, de outro destaca-se que esse aprendizado é simultâneo ao trabalho naquele centro de pesquisa, o que evidencia relações construídas sobre a base das assimetrias de recursos disponíveis.

Tanto é assim que alguns pesquisadores relataram a dificuldade de continuar orientando os alunos de doutorado quando eles vão realizar seus estágios doutorais em outros laboratórios, no sentido de que provisoriamente eles terão um outro orientador - ou "chefe" que poderá pedir outras atividades ou tarefas não previstas anteriormente e que não necessariamente fazem parte do projeto original de doutorado.

E esses laboratórios, dessas pessoas, querem publicar na Cell, na Nature, e aí vão contar uma história que vão entrar três ou quatro doutorados ali dentro. Tu manda o teu aluno para lá, que vai entrar numa história dessas, e eles não estão muito se importando se o resultado do aluno foi suficiente ou não para um artigo conosco, aqui (Ana, médica, UFRGS).

Apesar de eu ter uma colaboração boa com o pessoal da Espanha, estou tendo certa dificuldade, porque, por exemplo, até agora eu não consegui publicar o artigo da minha aluna que foi para Espanha. Por que? Porque o pesquisador lá desenvolveu um kit de captura e ele não deixa eu publicar antes dele publicar o artigo dele, e ele não publica. E a gente está numa agonia. Então, uma vez que o meu aluno vai para o laboratório dele, fica refém daquilo. Isso é complicado (Sara, bióloga, Unicamp).

A dificuldade de publicação desses artigos é uma questão importante, pois muitos programas de pós-graduação em genética e similares, no Brasil, exigem a publicação de ao 
menos um artigo para a obtenção do diploma de mestre ou doutor. Se o aluno é incluído "numa história dessas", entendida como uma pesquisa de longa duração, que envolverá o trabalho de diversas pessoas, ele pode ter dificuldade de publicar mais rapidamente - ainda que em uma revista de menor impacto que Cell ou Nature - de modo a poder concluir sua formação. Os relatos evidenciam, também, um elemento importante desse tipo de relação de colaboração: quando a "mão de obra barata" é um aluno, pode-se perder o controle do que ele fará no laboratório visitado, abrir mão do papel de orientador, mesmo que provisoriamente. Há, ainda, uma terceira dificuldade: os dados produzidos nesse laboratório não podem ser utilizados sem a autorização dos pares internacionais, o que aprofunda a relação de dependência, minando a autonomia da pesquisa no Brasil. Um exemplo disso é dado por outra entrevistada, que realizou seu pós-doutorado nos Estados Unidos.

\section{Você manteve os contatos que você fez no pós-doutorado? Conseguiram publicar juntos?}

Não publicamos juntos, por alguns motivos, mas o principal é que, como era um centro de referência muito forte, todos os trabalhos que eram publicados eram extremamente complexos, trabalhos grandes. E ele [supervisor] já tem certo destaque na carreira, ele busca, sempre, publicar trabalhos de impacto muito alto. Como o período que fiquei lá foi relativamente curto, quando a gente pensa em termos de grandes publicações, eu não tinha material para fazer uma publicação desse tipo. Foi um dos motivos pelo qual a gente não publicou. Tinha material para fazer uma publicação um pouco mais simples? Tinha. Claro que comparado com a nossa realidade a gente se frustra, porque você fala "poxa, eu tinha dados para fazer uma publicação muito boa".

\section{Mas você conseguiu publicar sozinha?}

Não posso publicar sozinha, ele não autoriza (Carolina, bióloga, USP/RP).

Nesse sentido, dependendo do grupo visitado - e de suas expectativas - o período fazendo pesquisa nos centros não terá como consequência uma publicação, se ela estiver fora dos padrões de qualidade e "impacto" almejados. E como estar nesse laboratório não implica a autonomia na utilização dos dados produzidos, é necessário obter - e aguardar - uma autorização. No caso da pesquisadora que realizou o pós-doutorado nos Estados Unidos, a autorização não foi concedida; no exemplo da aluna que visitou um laboratório na Espanha, a autorização está condicionada a que o pesquisador principal publique seu artigo. Nesse último, explicita-se que os pesquisadores dos laboratórios centrais têm prioridade, garantindo a originalidade e o ineditismo de sua publicação. Assim, os limites entre a cooperação e a subordinação são por vezes frágeis e porosos.

De toda forma, ainda que seja percebida uma relação de colaboração assimétrica, o que sobressai, nos relatos, é a ideia de que os dois lados têm a ganhar com a colaboração 
internacional. Além disso, alguns pesquisadores afirmam que os centros têm a necessidade dessa mão de obra estrangeira em seus laboratórios:

Acho que é muito importante você já ir com seu financiamento, porque eles não têm esse financiamento. É a mesma razão que leva você a ir num desses laboratórios no exterior e ver que a metade das pessoas que trabalham lá são latinos, chineses... Eles visam muito essa mão de obra que eles não conseguem ter recurso para contratar. Se pudesse seria só americano, sem muita gente de fora, mas como eles não têm tanto como contratar, tem que trazer mão de obra, acho que esse é um ponto importante na maior parte das colaborações internacionais (Lucas, biólogo, UFPA).

Na fala acima há outro elemento: os laboratórios dos centros também podem não ter recursos suficiente para contratar a quantidade de pesquisadores desejada, o que os leva a receber muitos estrangeiros, oriundos de países que financiam suas estadias, como é o caso, da China, na chave de que é preciso desenvolver a ciência nos países pobres. É explicitado, portanto, que nem nos centros a ciência tem todo o dinheiro necessário. Essa estrutura, um tanto predatória para os países pobres, pode ser pensada em termos de exploração, mas também como estratégia dos centros para atrair pesquisadores face à insuficiência de seus recursos,. Há, inclusive, um relato de uma busca dos centros por essa "mão de obra barata":

Tinha conhecido ele no congresso, em 2008, mas bem en passant. Teve outro congresso, em 2012. Fui, o conheci um pouco mais, conversamos, e ficamos em contato. Um dia ele me mandou um e-mail, quando começou o programa Ciências Sem Fronteiras, e disse: "um passarinho me contou que estão dando um monte de bolsas para alunos aí". E me perguntou se eu conhecia algum aluno. Eu disse que tinha um aluno que poderia estar interessado. E ele foi fazer o doutorado lá com ele. Abriu o contato, tinha alguém trabalhando lá, foi um trabalho bem-sucedido, o aluno se mostrou bem produtivo. E ele perguntou se tinha alguém interessado em fazer o pós-doutorado. Eu disse: "tem eu" (Lucas, biólogo, UFPA).

Evidencia-se, aqui, uma busca ativa pela "mão de obra barata", em que um pesquisador inglês, ciente de uma nova linha de financiamento do governo brasileiro, escreve a pesquisadores brasileiros, que trabalhavam com temas correlatos aos seus, buscando estudantes de doutorado e pós-doutorado para o seu laboratório. Nesse sentido, a importância do financiamento brasileiro fica marcante, ao menos para dar início a esse tipo de colaboração. Um dos entrevistados, que durante seu mestrado realizou um estágio de três meses em instituto de pesquisa francês, descreve da seguinte maneira as tratativas para a realização de um doutorado integral na instituição:

Quando estava para voltar, sentei com o professor (...) e disse: "tenho interesse em fazer meu doutorado aqui com vocês". E ele disse "está ótimo, não tem problema, só que eu não tenho bolsa para te dar, então volta para o Brasil, consegue uma bolsa e vem". Foi o que fiz (Daniel, biólogo, UFRGS). 
Novamente está presente a importância do financiamento brasileiro para o início e manutenção das relações com laboratórios em outros países. Salvo um pesquisador sênior, que obteve recursos da Fundação Rockefeller para custear sua estadia nos Estados Unidos, uma pesquisadora que realizou grande parte da sua formação na Alemanha, com bolsas desse país, e uma entrevistada que participou de um grande projeto financiado por uma agência de fomento inglesa, os demais pesquisadores entrevistados que tiveram experiência de formação ou pós-doutorado no exterior o fizeram com financiamento de agências de pesquisa brasileira. Em três casos, recursos do próprio país que visitaram foram obtidos para um segundo pósdoutorado na mesma instituição, e há também três relatos de que esse recurso foi oferecido, mas não aceito, por pesquisadores que decidiram retornar ao Brasil.

Em paralelo à discussão sobre "mão de obra barata", tem-se a ideia de que os pesquisadores brasileiros são bem recebidos e percebidos pelos seus pares em centros internacionais como bem formados, esforçados e dedicados.

Pensando na primeira vez que eu fui para fora do Brasil, em 1991, já naquela época o pesquisador brasileiro era muito conceituado lá fora, considerado um pesquisador que tem criatividade, que sabe se virar, que trabalha bem, que está com vontade de trabalhar (Daniel, biólogo, UFRGS).

Acho que a gente tem um envolvimento muito sério; o brasileiro que acaba se incluindo na colaboração, para ele é uma oportunidade muito grande, a gente agarra essa oportunidade de uma forma muito forte, então a gente também se dedica muito (Diego, médico, USP/RP).

Mais do que apenas bem formados e esforçados, tem-se a ideia de que, para o pesquisador brasileiro, a oportunidade de ir para o exterior, ou participar de uma colaboração internacional, é muito importante, e, por isso, ele concebe-a como uma oportunidade vital. A explicação para essa dedicação à colaboração internacional - ou ao trabalho nos laboratórios dos centros - está baseada na percepção de uma escassez do contexto local ou, nos termos do capítulo anterior, de uma periferia pensada em termos de falta:

Sei que os pesquisadores de genética brasileiros são muito bem-vistos fora. A gente brinca que a teoria é a seguinte: aqui a gente vive na escassez, escassez de reagentes, de recursos, de equipamento. E o brasileiro se vira, consegue trabalhar com o que tem. Quando ele sai, quando passa a trabalhar em um local que tem as coisas à vontade, o cara vai lá para cima. A gente vê muito isso. $\mathrm{O}$ pesquisador brasileiro que está fora, está em universidades pesadas americanas, ele é um fenômeno (...). Imagino que é por isso, é gente que passou graduação penando, mestrado penando, doutorado fazendo com o que tinha, aí consegue um local que tem tudo que ele sempre sonhou, para fazer as coisas que ele quer, o cara aproveita (Samuel, biólogo, UFPA). 
Além disso, o contexto local, em que os pesquisadores precisam realizar uma série de tarefas para a manutenção da pesquisa, como visto no capítulo anterior, prepara o pesquisador para a resolução de problemas, e ele se torna uma boa mão de obra:

Meu supervisor [no Canadá] dizia que preferia mil vezes receber alguém para fazer um pós-doutorado que venha de um país distante do que de lá. Por que? Aqui no Brasil, e até hoje, se tiver um problema com as chaves do laboratório eu vou ter que resolver. Lá, não, é tudo estabelecido, tu trabalhava das nove às cinco e era muito, porque a gente não precisava se preocupar com a manutenção do dia a dia do laboratório (...).

Mas eu não entendi porque ele preferia pesquisadores...

Porque quem chega do nosso país está acostumado a passar tantas dificuldades [risos] que o pessoal de lá não está acostumado. Ele dizia que a gente acabava produzindo muito mais do que uma pessoa local, que estava acostumada a uma série de facilidades. A gente, por exemplo, não se incomodava de levantar da cadeira e resolver um problema, quando tinha alguma crise, alguma dificuldade. A gente tinha treinamento para resolver as dificuldades (Rita, médica, UFRGS).

$\mathrm{Na}$ época de citogenética - que estava evoluindo para citogenômica - o pessoal que saía daqui do Brasil era absorvido em todos os laboratórios, porque tem uma vivência, uma experiência, inclusive para lidar com reveses, que os outros não têm (Beatriz, médica, Unicamp).

O que no capítulo anterior foi descrito como falta, do ponto de vista da formação dos pesquisadores, é visto como um diferencial, algo que os prepara para resolver problemas, "lidar com reveses", uma experiência que pesquisadores dos centros, dotados de melhor infraestrutura - entendida em sentido amplo, incluindo serviços técnicos, secretariado, pessoal especializado -, não possuem e não estão dispostos a desenvolver, pois não a consideram parte de suas obrigações no contexto de trabalho. Nesse sentido, se de um lado falta infraestrutura, de outro os brasileiros são considerados - e se consideram - pesquisadores muito bem formados ${ }^{89}$, dispostos a trabalhar, e que aproveitarão ao máximo as oportunidades abertas pela colaboração ou pela estadia nos centros.

Ainda que muitos entrevistados utilizem a expressão "mão de obra barata", tal termo é impreciso, pois para o Brasil ela tem um custo significativo - na forma de bolsas de agências de fomento no nível estadual e federal - e, para os laboratórios visitados no exterior, ela é uma mão de obra completamente gratuita, bem formada e, como visto acima, capaz de lidar com as dificuldades que se apresentam no cotidiano de pesquisa. Ao mesmo tempo, nas

89 Tal percepção parece ser bastante importante para os entrevistados, considerando que em cerca de dez entrevistas esteve presente certa preocupação com o Programa Ciências sem Fronteiras, entendido pelos entrevistados como enviando alunos ainda muito no início da formação, sem seleção adequada, e muitas vezes mais interessados em viajar do que em trabalhar. Nesse sentido, os entrevistados viam esse programa do governo brasileiro como podendo minar a credibilidade adquirida pelo pesquisador brasileiro em laboratórios dos centros, e potencialmente dificultar futuras colaborações. 
entrevistas, há apenas dois casos citados de jovens pesquisadores dos centros que passaram algum tempo em laboratórios brasileiros, sendo um deles financiado mediante bolsa de pósdoutorado da Fapesp e o outro por um programa de acordo bilateral entre a Capes e o Serviço Alemão de Intercâmbio Acadêmico (DAAD). Ou seja, além de poucos casos relatados, essas estadias foram também apoiadas por políticas científicas locais, evidenciando mais uma dimensão dessa relação assimétrica, em que é possível pensar na periferia financiando tanto a sua mão de obra que vai aos centros como, também, contribuindo em parte para financiar os pesquisadores que visitam as periferias.

Simultaneamente, destacam-se nas entrevistas os aspectos benéficos - para o Brasil desse tipo de relação, em princípio assimétrica. Primeiro, porque o financiamento do pesquisador pode ser brasileiro, mas os experimentos - que envolvem equipamentos e reagentes caros - são custeados pelo laboratório visitado. Segundo, porque o desenvolvimento tecnológico acontece nos centros, em que está a pesquisa de ponta, em que se pode ter acesso a e aprender determinadas técnicas não disponíveis no contexto local. Nesse sentido, a estadia no exterior é vista como importante tanto para o desenvolvimento da pesquisa quanto para a formação dos pesquisadores, mesmo que seja para "trabalhar de graça" por um período.

\subsubsection{Diversificação de temas de pesquisa, ampliação de publicações e pressão por "internacionalização"}

A terceira razão para que pesquisadores dos centros colaborem com pesquisadores brasileiros, destacada em 15 entrevistas, é a possibilidade que esses pesquisadores têm de diversificar seus temas de pesquisa:

Minha aluna ficou seis meses no NIH. O que ela foi fazer lá? Eu passei pouco tempo no exterior, mas eu estou procurando mandar os meus alunos, como colaboração. Ela foi aprender uma técnica nova, que a gente não tem aqui, e que vai ser importante para a gente estudar as variantes dos pacientes (...). Para mim, é buscar um conhecimento que eu não tenho e que vai ser importante para responder as minhas perguntas. Por que ele recebe? Porque para ele também é importante fazer essa troca. (...) Acho que eles ganham, também, porque geralmente não é a linha de pesquisa deles. Por exemplo, no caso do NIH: ele tem a técnica, mas ele não trabalha com a epilepsia, mas a gente usa a técnica dele nos estudos da gente, e com isso ele colaborou com esse conhecimento (Julia, bióloga, Unicamp).

É possível perceber que, muitas vezes, justamente porque a principal motivação dos pesquisadores brasileiros para ir ao ou para colaborar com o exterior é o aprendizado de determinadas técnicas de pesquisa, os temas ou questões de pesquisa não precisam ser - e 
frequentemente não são - os mesmos do grupo visitado. Isso permite, inclusive aos pesquisadores do exterior, ver sua técnica funcionar em um tema de pesquisa diferente.

Ainda que os grupos tenham algumas afinidades temáticas, as questões de pesquisa podem não ser necessariamente as mesmas:

Com o colaborador francês, foi estabelecer contato com a pessoa, por conta de um interesse comum, e ele fez uma parte, eu fiz outra parte. Partiu de uma pergunta minha, isso gerou publicação, que os dois são coautores, então isso é importante para os dois lados; e foi um aspecto do trabalho que ele não estava se perguntando, não estava olhando, então ele só ganhou, porque isso acrescentou coisas para ele. Não diretamente na pesquisa e nas perguntas que ele estava fazendo, nesse caso, mas ele se beneficiou, de ter mais colaboração, de ter publicação (Isabela, bióloga, USP/RP).

Está presente, acima, um elemento diferente, mas complementar à diversificação dos temas de pesquisa, que é a ampliação do número de publicações, ainda que sejam em questões mais marginais à linha de pesquisa dos colaboradores internacionais. A importância da ampliação do número de publicações aparece mais diretamente em algumas outras entrevistas e parece ser um motivo bastante frequente - e pragmático - para realizar uma colaboração em geral, independentemente da inserção institucional e nacional do pesquisador.

$\mathrm{O}$ que eles ganhariam com isso... Se eles têm tudo, e eles podem fazer as coisas sozinhos lá, sem precisar colaborar... Eu entendi. Na verdade eles têm interesse em colaborar primeiro porque vai gerar produção científica para eles, vai gerar um artigo para eles (Manuela, bióloga, Unicamp).

Nesse caso, a especificidade da pesquisa genética brasileira pode não ser o mais importante, embora muitas vezes esse motivo se relacione com outros, como o "acesso às amostras", ou a obtenção de "mão de obra barata":

O câncer gástrico é muito comum na nossa região, tem uma alta incidência aqui, em outras regiões não é tão comum. Na Europa, por exemplo, não tem câncer gástrico, por isso que ele queria estudar. (...) Eu tive que apresentar para o [pesquisador espanhol] uma proposta, uma ideia interessante, e, ele, muitas ele aceitou, outras ele não aceitou, porque ele achou que aquilo dali não ia dar muito resultado. Então potencialmente ele vê que aquilo pode virar um artigo importante (Carlos, biólogo, UFPA).

Acho que quando algum aluno vai para fazer, por exemplo, um doutorado sanduíche, isso significa alguém que vá trabalhar lá, que tem um projeto definido, mas esse projeto sempre tem algum interesse para o grupo de lá, então pode significar, sim, um outro pesquisador que pode desenvolver um aspecto diferente da pesquisa para eles (Erica, bióloga, UFRGS).

Os exemplos acima mostram que podem haver várias razões para a colaboração, e isso vale para as duas partes envolvidas: se muitas vezes o aprendizado de novas técnicas se conjuga à ideia de que é mais fácil publicar artigos em coautoria internacional, como visto no 
capítulo anterior, na relação inversa muitas vezes a ampliação dos temas de investigação caminha junto com o acesso a amostras diferentes, ou a ter uma pessoa adicional trabalhando no laboratório. Nesse sentido, a ampliação dos temas e número de publicações pode ser considerada como complementar aos dois motivos principais tratados acima: "acesso às amostras" e "pesquisadores brasileiros como mão de obra barata".

Um outro elemento, que se relaciona com a ampliação do número de publicações, fundamentais para a avaliação da carreira científica nas diversas instituições de ensino e pesquisa, é o que os entrevistados nomearam como "desafio da internacionalização". Os entrevistados identificam pressões institucionais - da própria instituição de que fazem parte e das agências de fomento - para manter colaborações internacionais e ter uma grande quantidade de publicações. Segundo eles, essa pressão não se daria apenas no Brasil, mas também nas instituições dos centros com os quais colaboram. Nesse sentido, os entrevistados afirmam que a necessidade de internacionalização da pesquisa não afeta apenas os pesquisadores brasileiros, mas também aqueles que os recebem:

O que eles ganham recebendo uma pessoa lá? É colaboração! Para eles é importante na carreira deles, também, colaborar com gente de fora. Eu estava conversando, por exemplo, com essa professora que está aqui e ela submeteu um projeto para vir para ficar mais dois meses o ano que vem aqui e mais dois meses em 2019. Ela falou que só o fato de submeter esse projeto é importante para a carreira dela. Porque a gente é avaliado. E nessa avaliação, o fato de você ter colaboração tem um peso (...). Existe o ganho de conhecimento, o lado romântico da coisa é o conhecimento (...). E o outro lado é porque existe uma necessidade de fazer isso, por questão de sobrevivência da ciência, e também porque isso é uma questão de carreira. Espera-se que a gente tenha colaboração, espera-se que a gente não fique fechado no laboratório (Julia, bióloga, Unicamp).

É porque, tanto aqui no Brasil quanto no exterior, os pesquisadores, os professores, são sempre avaliados (...). O que vai avaliar? Você tem que mostrar a sua produção em cursos de graduação, de pós-graduação, produção científica, cooperação que você tem com outros países. E é a mesma coisa eles lá, se eles não fazem, se eles se fecham, um laboratório, uma equipe que se fecha, não cooperou com ninguém, não interagiu com ninguém, eles vão dissolvendo essa equipe. Então imagina uma equipe brasileira que chega lá e fala "eu quero cooperar com vocês"; para eles conta ponto também, eles são pontuados (Rafael, biólogo, USP/RP).

Como dito na introdução, a "internacionalização da ciência” está presente nas políticas científicas da maioria dos países dos centros e das periferias, em documentos oficiais e nos programas de agências financiadoras. Mas, nas falas acima, ela reaparece em uma dimensão mais normativa, entendida como uma consequência outra da formulação das políticas científicas, que é a consequente criação de critérios para os procedimentos de avaliação do 
pesquisador, formulação de requisitos necessários para que ele possa melhorar seu currículo, ou mesmo avançar na carreira, em sua instituição de trabalho.

\subsubsection{Colaboração como sinônimo de ajuda}

A quarta razão, presente em seis entrevistas, é a ideia de que os pesquisadores de outros países recebem brasileiros - ou com eles estabelecem relações - para auxiliar em suas pesquisas. Nesse sentido, a cooperação é entendida como sinônimo de "ajuda" (Gaillard, 1996) e se desenvolve no marco de relações historicamente e assimetricamente estruturadas, nas quais os países centrais, por meio de seus governos e agências, direcionam a assistência aos países periféricos segundo seus interesses e conveniências. Oldham (1995) aponta para dois sentidos (ou significados) mais comuns da cooperação científica internacional. O primeiro descreve a cooperação entre pesquisadores que trabalham em países diferentes, tanto a do tipo informal, entre cientistas individuais, quanto a cooperação mais formal em torno de projetos científicos definidos, implicando grupos de pesquisa, e regida por acordos oficiais. A segunda acepção da expressão aparece como sinônimo de ajuda, e se refere ao fluxo de recursos aos países em desenvolvimento para auxílio do desenvolvimento de suas capacidades científicas e tecnológicas. Nesse sentido, ao descrever "colaborações internacionais", o que mais aparece, na fala dos entrevistados, é a primeira acepção do termo, porém, mais marginalmente é possível perceber essa segundo acepção:

Eu acho que o pessoal lá fora costuma receber porque tem essa cultura de disseminação e de ajudar, principalmente o pessoal que vem de outros centros como da América Latina ou coisa assim. Mas é difícil falar o que passa na cabeça das pessoas (Julia, bióloga, Unicamp).

A gente está em um país que é menos privilegiado, no geral, em relação a outros países, como Estados Unidos e Alemanha, por exemplo. (...) Então acho que esses pesquisadores de fora, que eu mencionei, têm essa visão, deles, de alguma maneira, tentarem engrandecer aqui, formando as pessoas daqui, ensinando as pessoas daqui.(...) Então, esse tipo de colaboração que engrandece o nicho de pesquisadores daqui (Samuel, biólogo, UFPA).

Ainda que minoritária, essa ideia de colaboração como "ajuda" ou "solidariedade" está presente quando pesquisadores destacam que a colaboração completamente igualitária ou equilibrada nem sempre é possível, sendo necessário que os pesquisadores em centros com mais recursos compreendam que um pesquisador brasileiro não consegue necessariamente contribuir, na mesma medida, em um determinado trabalho. Essa ideia é destacada abaixo, quando uma entrevistada afirma ser importante haver um "perfil solidário" na troca científica entre centros e periferias. 
Não gosto daqueles pesquisadores que só trabalham com a via de mão dupla. Espero de colaboradores de países desenvolvidos que eles entendam que às vezes não consigo dar na mesma proporção. Mas se é uma pessoa solidária, ela vai me receber, vai receber meu aluno, sem pedir a mesma equivalência na troca. Às vezes eu não tenho como colocar o mesmo montante de recursos em um projeto, mas é importante que o meu estudante vá para lá. Esse tipo de coisa eu também avalio muito, o perfil solidário da troca científica, que às vezes é desigual, e eu não acho que tenha que ser só uma relação de negócios, de business científico, eu acho que tem que ser uma relação prazerosa, afetiva, entre pessoas que buscam trabalhar com ciência, às vezes em ambientes não muito favoráveis (Vanessa, bióloga, UFRGS).

Essa ideia de que a colaboração tem que ser solidária está presente quando a mesma entrevistada descreve sua relação com uma pesquisadora venezuelana:

Acho que solidariedade é uma coisa fundamental. Tenho uma colaboradora de muitos anos (...), que é uma pesquisadora venezuelana. A gente sempre tenta trazer ela, manda a passagem, envolve ela em algum congresso, alguma banca. Ela é minha amiga, ela não é só pesquisadora, ela é minha amiga. Ela tem que sair de lá, mas o currículo dela não é mais competitivo, então não consigo trazer ela como pesquisadora convidada pelo CNPq (...). Mas eu jamais vou deixar ela na mão. Não é só o que o pesquisador pode contribuir comigo; como pesquisadora, no momento, ela não pode me dar nada, mas eu posso dar algo para ela (Vanessa, bióloga, UFRGS).

Uma boa colaboração com pesquisadores dos centros implica a aceitação de que faltam coisas à periferia, que nem sempre os pesquisadores sediados em instituições brasileiras possam contribuir na mesma magnitude em uma publicação, principalmente em termos de recursos financeiros e tempo, o que pode, inclusive, dificultar o estabelecimento de colaborações de mais longa duração, para além da ida pontual de um aluno ou pesquisador sênior para realizar um estágio de pesquisa. Os termos de uma colaboração incluem elementos de confiança, assim como relações de poder construídas sobre a base das assimetrias de recursos disponíveis. Mas, na fala acima, o Brasil atua como centro, para a pesquisadora da Venezuela. Ao contrário, no exemplo abaixo, a ausência de reciprocidade impediu o estabelecimento de uma colaboração com um grupo inglês:

$\mathrm{Eu}$ já tentei estabelecer colaboração com um grupo [da Inglaterra. O papa das Talassemias Alfa está lá. Um inglês bem tradicional. Mas aí o acesso é bem difícil. Eu tive, uma época, uma família para estudar, escrevi para ele, pedi para ir lá e levar o material, ele não facilitou, não. Ele receberia o material, poderia até analisar, mas quanto a mim, ficar lá, eram outros quinhentos. Depois me mandou o resultado. Ele atenuou um pouco dizendo: "olha, se você quiser vir por uma semana, tudo bem!".

\section{E qual a dificuldade?}

Não sei. Se eles tiverem muita demanda de alunos da Europa, mesmo dos Estados Unidos, acho que eles preferem. (...) Um outro ponto é que eu não estava indo para ficar um periodo em que eu pudesse me integrar em um projeto dele. Trabalhar para ele. Eu ia lá para olhar a técnica e ver se eu 
poderia fazer aqui. Isso também limita bem o interesse da pessoa. O que eu acho uma bobagem! Eu não faço isso (...). Este laboratório é aberto para todo mundo que tiver interesse (Natalia, bióloga, Unicamp).

Se uma das motivações identificadas para a colaboração é o auxílio a pesquisadores brasileiros, e não a troca igualitária, a ausência de contrapartida para o pesquisador de Oxford não facilitou a ida da pesquisadora brasileira a sua instituição. Essa dificuldade pode explicar porque muitos entrevistados, em locais considerados como "ilhas de excelência", destacam que seus laboratórios estão sempre abertos para que alunos de outras instituições possam aprender determinada técnica, ainda que a expectativa seja de que isso se torne uma colaboração. Os pesquisadores entrevistados, inseridos nos centro de excelência do Brasil, afirmam que os grupos dos centros precisam ser solidários e compreender as dificuldades presentes na periferia, sustentando, ao mesmo tempo, que exercem essa solidariedade em seus laboratórios em relação a pesquisadores perifericamente localizados no sistema nacional.

\subsubsection{Expertise dos geneticistas brasileiros}

A última razão, apontada em seis entrevistas, é a contribuição brasileira no que diz respeito à produção do conhecimento, para além da questão das amostras, a partir de determinados conhecimentos especializados ou do domínio de certo campo de conhecimento ou metodologia. Por exemplo, uma pesquisadora da UFRGS foi realizar um pós-doutorado em um laboratório nos Estados Unidos que estava pesquisando doenças hepáticas, e com isso pôde contribuir com eles:

\section{Fiquei com uma dúvida: não era um grupo de genética? \\ Não!}

Então você foi para levar um pouco esse conhecimento específico?

Exatamente! Tanto é que eu fiz um passo a passo do que tinha que ser analisado com o racional genético: tem que olhar isso, depois tem que olhar aquilo, depois tem que olhar aquilo outro, montei umas tabelas que ajudavam a fazer isso meio automático, e talvez tenha sido a maior contribuição para o grupo deles isso que eu fiz: "Olha, é assim, tem que olhar isso, não adianta olhar mutação sinônima, tem que olhar mutação não sinônima, se isso aqui já está descrito no banco de dados, se isso aqui tem uma frequência de tanto, não é o que causa doenças". Coisas até bem simples de genética que, como eles não tinham essa formação, eles eram um grupo que trabalhavam muito com expressão gênica, modelos animais, acho que foi bom para eles (Thais, bióloga, UFRGS).

Experiência similar é destacada por um pesquisador de Belém, cujos conhecimentos de estatística permitiram que ele se inserisse em outros trabalhos do grupo com o qual realizou estágio doutoral, na Alemanha: 
Eu tinha o meu projeto individual, mas eu fui me envolvendo nos projetos de outros colegas lá, ajudando a analisar os dados, porque eu era a única referência em termos de genética de populações, que entendia um pouco de estatística, de análise de dados, e aí acabei me envolvendo em outros trabalhos que eles estavam fazendo (Lucas, biólogo, UFPA).

Nos dois casos, considerando uma crescente especialização e divisão do trabalho no interior da pesquisa biomédica, ambos os pesquisadores puderam se inserir nos grupos que visitaram devido ao domínio de conhecimentos específicos não disponíveis na equipe de pesquisa que os recebeu, o que não significa que esses conhecimentos não pudessem ser buscados em outros laboratórios dos centros. Especificando essa razão para a colaboração com pesquisadores do Brasil, é possível olhar para outro exemplo, de uma pesquisadora que, ao relatar o processo de escrita de um de seus artigos em colaboração internacional, afirma:

Um pesquisador muito importante [norte-americano], entrou em contato, porque ele estava encontrando alguns resultados estranhos [ênfase], que ele não estava conseguindo explicar. Ele estava usando, na verdade, dados já publicados, de bancos públicos de nativos americanos (...). E ele fez umas outras análises e descobriu umas coisas estranhas, então entrou em contato comigo dizendo que não estava conseguindo interpretar aquilo, e a gente montou uma estratégia, um modelo, e acabamos publicando esse artigo.

Nesse exemplo está em primeiro plano justamente o conhecimento específico que a pesquisadora tem, sua expertise no tema, que contribuiu para a publicação ao auxiliar a desvendar as "coisas estranhas" encontradas pelo pesquisador estadunidense. É a sua experiência em pesquisas com "nativos americanos", sua inserção internacional nessa temática - que inclui publicações em periódicos de prestígio -, e a posse de amostras de outras populações indígenas não incluídas no trabalho original que abriu espaço para a colaboração. Nota-se, com isso, a multidimensionalidade e complementaridade de atuação dessa miríade de razões: se, aqui, busco compreender cada uma delas de maneira autônoma, elas atuam continuamente e se reforçam mutuamente.

Outro tipo de expertise descrita como importante, e que também facilita as colaborações, é a formação clínica dos pesquisadores em genética médica. Evidentemente, isso foi destacado por aqueles que pesquisam doenças genéticas, e que têm sua formação em medicina, não em ciências biológicas:

Eles [pesquisadores estrangeiros] não têm tudo! Não tenho dúvidas de que o geneticista brasileiro, o médico geneticista brasileiro, tem uma bagagem maravilhosa de clínica, em qualquer lugar que ele foi treinado. A gente é muito bom nisso, muito bom. E quanto mais eles vão se especializando no exterior, menos eles têm isso (...). Eu acho que o olhar que a gente leva é importante, bem especificamente em clínica (Gabriela, médica, Unicamp). 
Novamente é possível pensar em termos de divisão do trabalho e especialização: como descrito no depoimento acima, cada vez mais o pesquisador, nos centros, não tem contato com os pacientes, há um médico dedicado apenas para isso. No contexto brasileiro, em que assistência e pesquisa encontram-se bastante imbricadas, tal especialização não é possível, mas isso é significado positivamente por alguns pesquisadores entrevistados, porque permitiria uma visão mais abrangente das questões de pesquisa, de um lado, e uma expertise diferenciada, de outro - no caso, "ser bom em clínica". Os clínicos brasileiros tiveram historicamente uma excelente formação, que permanece no presente. Mas pode se interpretar que isso também está ligado ao fato de a medicina não conseguir andar no mesmo ritmo da medicina altamente tecnológica dos centros. No capítulo 1, discutiu-se em maior profundidade as ligações, tensões e ambiguidades na relação entre atendimento e pesquisa. A falta de especialização que, de certa perspectiva foi considerada desfavorável - por não permitir uma maior profissionalização do atendimento e uma maior dedicação à pesquisa, por criar confusões, produzindo expectativas nos pacientes -, na situação específica relatada na fala acima aparece como um diferencial positivo que os médicos-pesquisadores brasileiros têm, se comparados àqueles dos centros. Características apontadas no capítulo anterior como sendo negativas - em comparação aos centros -, podem ser, ao mesmo tempo, positivas, em situações particulares de colaboração. Nesse sentido, são as configurações e situações específicas que dão sentido aos elementos: considerado de certa perspectiva, as características da pesquisa brasileira são todas negativas, em relação as características positivas dos centros; mas, em outras situações, as mesmas características podem ser positivadas, no sentido de uma participação, mesmo que marginal, na pesquisa.

Outro exemplo que implica a utilização da expertise brasileira é o de uma colaboração com uma pesquisadora da Alemanha, que o pesquisador brasileiro conheceu em um congresso e com a qual estabeleceu uma "colaboração formal" mediante edital CAPES-DAAD. O pesquisador relata que alguns alunos seus foram fazer estágio na Alemanha, mas que eles também receberam uma aluna desse país em seu laboratório em Porto Alegre:

Nós tivemos uma aluna da Alemanha que passou seis meses com a gente; foi excelente e acho que para ela também, porque ela viu uma outra realidade, um outro mundo. E foi produtivo, foi muito bom, ela trouxe as amostras, fez as análises moleculares aqui que ela não podia fazer lá, porque eles não tinham. (...). Quando ela veio da Alemanha, trouxe amostras de pacientes de lá e aplicou metodologias que, não que eles não pudessem fazer lá, mas que não estavam estabelecidas no laboratório. Era muito mais fácil, mais barato e mais lógico, em vez de passar seis meses tentando estabelecer algo novo no seu laboratório, pegar as amostras, trazer aqui, e em um mês está resolvido o problema, com um custo muito menor (Daniel, biólogo, UFRGS). 
Aqui é possível ver o mesmo movimento descrito no item anterior, quando um pesquisador brasileiro se desloca para um centro de pesquisa no exterior no intuito de fazer algo mais rapidamente do que faria em seu laboratório. Ainda que essa tenha sido a única experiência desse tipo descrita com a direção contrária, merece ser destacada, pois se trata de uma colaboração em que um laboratório brasileiro, por meio da colaboração estabelecida, conseguiu "acelerar o trabalho" de uma aluna do centro. Nesse mesmo sentido, há um outro caso de inversão da relação, em que um pesquisador de Belém auxilia um pesquisador espanhol a obter recursos financeiros para a pesquisa:

Depois abriu um projeto que podia ter membros estrangeiros, e eu coloquei ele. Era uma época em que a Espanha estava em crise, e foi bom porque o órgão de fomento dele também entrava, então o dinheiro ia para lá e vinha para cá, ele comprava a parte dele, foi muito bom. Depois, os artigos dele ele me mandava para ler, me perguntava o que eu podia fazer nesse artigo, eu fazia alguma coisa, e comecei a entrar nos artigos dele. Foi muito bom para mim, porque passei a fazer parte do staff dele (Augusto, biólogo, UFPA).

Em um momento em que a Espanha passava por dificuldades financeiras, a colaboração com o Brasil permitiu a obtenção de recursos. É curioso pensar como, ainda assim, o pesquisador de Belém considera que a colaboração foi, de certa forma, assimétrica, mais benéfica para ele - que passou a fazer parte do "staff" de uma figura importante na genética - do que para o pesquisador espanhol, que naquele momento não dispunha de financiamento para realizar a sua pesquisa. Aqui está presente uma dimensão simbólica da divisão hierárquica que não se limita à ciência. O pesquisador espanhol pode ser de país pouco central para a ciência, e com dificuldades financeiras, mas ainda pode mobilizar contatos importantes, porque está mais próximo do centro científico - não em termos geográficos - do que um laboratório de um país latino-americano.

De toda forma, esses foram os três únicos exemplos concretos de colaboração, presentes nas entrevistas, que invertem as relações centro e periferia em três dimensões diferentes: a pesquisadora de Porto Alegre é que tem a expertise necessária para a análise de determinados dados, o laboratório da UFRGS permite acelerar a produção dos dados de uma aluna da Alemanha, e o pesquisador sediado no Norte do país, que ajuda um colega espanhol durante uma crise de financiamento. Nesse sentido, a sexta razão, minoritária, elencada aqui pode ser considerada como formas de inversões nas relações entre centros e periferias.

Ao mesmo tempo, destaca-se que esses exemplos não foram obtidos no momento da entrevista em que se perguntou diretamente porque os pesquisadores estrangeiros tinham interesse em colaborar com pesquisadores brasileiros; são descrições feitas quando 
perguntados sobre um artigo ou colaboração particular, identificados via Lattes. Isso significa que, ao serem perguntados diretamente, o que vem à mente de imediato são razões que estão mais no âmbito das relações mais "clássicas" entre centros e periferias, ainda que nas entrevistas existam alguns exemplos de subversão dessas relações, mas que não são formulados e percebidos dessa maneira.

As principais razões identificadas pelos entrevistados para que laboratórios dos centros tenham interesse em colaborar com geneticistas brasileiros estão sumariadas no quadro abaixo. As mais importantes, tanto em termos de presença nas entrevistas, quanto em termos da discussão desta tese, que busca analisar as relações entre centros e periferias na genética humana e médica a partir de laboratórios brasileiros, são as duas primeiras.
1. Acesso às amostras da população brasileira
2. Pesquisadores brasileiros como mão de obra barata/gratuita
3. Diversificação de temas de pesquisa e ampliação de publicações
4. Pressões por internacionalização
5. Colaboração como sinônimo de ajuda/solidariedade
6. Expertise dos geneticistas brasileiros

A análise das colaborações internacionais, apresentada neste capítulo e no anterior, permitiu verificar que o foco no conteúdo científico da colaboração - troca de expertise para a criação de novos conhecimentos - não é suficiente para explicar algumas de suas motivações, como o acesso a técnicas de pesquisa, a construção de carreiras e ampliação de publicações, a aplicação de um modelo a condições locais, o acesso às amostras, a obtenção de financiamento para pesquisa, ou mesmo a sua aceleração. É possível afirmar, em resumo, que as colaborações internacionais oferecem dois tipos de oportunidades. Do ponto de vista dos cientistas brasileiros, eles podem aprender como a ciência e tecnologia dos centros funciona, e desempenhar um papel de intermediário na implementação do conhecimento científico em seu contexto local. Da perspectiva das organizações de pesquisa centrais, essas colaborações formam conexões internacionais que lhes permitem promover e transferir seu conhecimento, e, sobretudo, ter acesso às amostras locais, além de poderem se utilizar de uma mão de obra extremamente talentosa e motivada da periferia. No entanto, a discussão sobre o acesso às amostras ainda precisa ser complexificada, pois envolve vários níveis e tensões. 


\subsection{Brasil fornecedor de amostras?}

Como visto, uma das razões mais recorrente para explicar porque são buscados por pares dos centros para realizar colaborações internacionais se vincula ao interesse desses pesquisadores em ter acesso às amostras da população brasileira, seja do ponto de vista das doenças genéticas, da genética de populações, da genética médica populacional ou da genética do câncer. Ao mesmo tempo, todos os pesquisadores entrevistados afirmaram que evitam fazer colaborações internacionais em que eles estejam apenas na posição de fornecedores de amostras, de matéria-prima. Ainda assim, esse é um tema recorrente nas falas, algo que muitos dizem existir nas práticas de pesquisa da área no Brasil, mas que deve ser evitado.

Esta seção busca complexificar o papel do Brasil como fornecedor de "matériaprima", como ele é aceito e/ou confrontado pelos pesquisadores e, principalmente, quais estratégias eles estabelecem para não ficarem restritos a essa posição, no momento de uma colaboração internacional, ainda que relatem que frequentemente essa é a posição que se espera deles. Paralelamente, é possível discutir em maior nível de detalhe e complexidade os processos de divisão do trabalho nessas colaborações internacionais.

O papel atribuído ao Brasil, por parte dos pesquisadores dos centros, como local fornecedor de amostras é destacado por diversos entrevistados. Primeiramente, enquanto uma caracterização histórica das relações com pesquisadores estrangeiros:

No seu memorial você conta que durante a iniciação científica você fez
um trabalho de campo em parceria com Ipesquisador norte-americano]
Foi, essa colaboração foi durante a iniciação científica. Ele chegou a vir
algumas vezes para cá, foi uma colaboraçâo mais unilateral, no sentido de
ele vir para cá e querer pegar as amostras (...). A gente estava começando,
então era aquela relação um pouco desigual, com os americanos, que
naquela época ainda era mais acentuada do que é hoje. Hoje a gente tem
mais respeito, mais reconhecimento, mas na época era uma coisa muito mais
unilateral do que bilateral, ele chegou a doar alguns equipamentos, algumas
coisas, mas o principal retorno foi coautoria (...) em trabalhos com ele. Entendi, o interesse dele eram as amostras das populações indígenas... Eram amostras e a gente era só o meio (...). Mas as minhas colaborações após essa tenderam a ser colaborações boas, em que existia bilateralidade, reciprocidade, respeito pela nossa competência (Lucas, biólogo, UFPA).

Nesse sentido, a relação desigual (ou "unilateral") entre os pesquisadores é descrita como fazendo parte da história da genética de populações, embora no presente se aponte para uma melhora em termos de "reciprocidade", de uma relação mais igualitária, que reconhece a "competência" dos pesquisadores brasileiros, não mais vistos apenas como "meio" de obtenção de amostras. No primeiro capítulo desta tese, quando discuti o processo de institucionalização da pesquisa em genética no Brasil, destaquei que as amostras tiveram um 
papel importante nas primeiras colaborações internacionais: Dobzhansky tinha interesse em coletar e estudar espécies tropicais de drosófilas, e, principalmente, James Neel e Francisco Salzano estabeleceram um grande projeto colaborativo envolvendo o estudo das populações indígenas situadas no território brasileiro. Ao mesmo tempo, se as amostras foram parte importante dessas colaborações, seria simplificador tomá-las como os únicos elementos.

Essa relação entre pesquisadores dos centros e das periferias, considerada como tendo um caráter marcadamente "unilateral" ou "desigual", também foi formulada, em algumas entrevistas, em termos regionais:

No passado - eu diria que ainda pode acontecer, mas não é mais tão evidente isso - existia uma associação assim: estou em Belém e tem um grupo em São Paulo interessado em estudar populações indígenas. Vamos fazer uma colaboração? Vamos. O que o Matheus vai fazer? Ele vai coletar sangue dos indígenas e mandar para a gente. Isso não é uma boa colaboração. No final o meu nome estará no artigo, mas o que eu fiz? Eu coletei amostras. É importante? É importante, faz parte do projeto, as amostras são necessárias. Mas, do ponto de vista intelectual, não é muito importante. Isso não trouxe para mim nada, não agreguei nada para o meu grupo, em termos de conhecimento, não trouxe nenhum benefício, a não ser a vaidade de ver meu nome em um artigo publicado (Matheus, médico, UFPA).

Busco uma colaboração onde haja interação e integração de procedimentos e de objetivos. Essa é a colaboração ideal. Aquela de lógica de país subdesenvolvido é horrivel, aquela da dominação do exterior para o Brasil... E aconteceu muito isso no Brasil.

Em que sentido? Que a gente contribuía com as amostras?

Basicamente isso, enviar amostra para eles estudarem. E esse era um modelo que se reproduzia em nivel continental, do exterior em relação ao Brasil, e dentro do Brasil, também, do Sudeste em relação à Amazônia e o Nordeste.

Você acha que esse cenário mudou?

Mudou. Era horroroso. Isso não é colaboração, é exploração (Débora, bióloga, UFRGS).

As falas acima evidenciam que o mesmo tipo de associação "unilateral" entre pesquisadores dos centros e das periferias, ou, em termos mais fortes, esse mesmo tipo de relação de "exploração", identificada no passado da genética brasileira, se reproduzia no interior do país. Novamente é possível conceber, a partir de uma abordagem relacional, um centro no âmbito da periferia, centro esse que exerce o papel de centralização dos dados e análise das amostras coletadas em outras regiões do país.

Contemporaneamente, há relatos desse tipo de colaboração "unilateral”, mas também muitas nuances nessas relações. Uma pesquisadora, narrando sua experiência em um consórcio internacional, afirma: 
Meu grupo nunca foi um grupo do tipo que, infelizmente, acontece muito comumente no Brasil, que manda amostras para serem estudadas no exterior. Nós não fazemos isso, certo? O que nós fazemos é realmente uma colaboração. Em algumas situações nós entramos com dados para formar um grupo grande de algumas análises, mas na maior parte do tempo nós fazemos as análises e nós propomos os projetos, então é realmente uma colaboração. Devo dizer para você que isso é muito raro no Brasil. Na maior parte das vezes, o que os nossos colegas chamam de colaboração é colher DNA do paciente e mandar para um laboratório no exterior fazer a análise. Isso não é colaboração, certo? Porque você não tem a parte intelectual da análise, você não tem a parte intelectual de propor o projeto, você não pediu o financiamento para o projeto. Mesmo que o seu nome entre no artigo, você não vai ter uma grande participação intelectual (Sofia, médica, Unicamp).

A pesquisadora descreve acima o que seria "realmente" uma colaboração com pesquisadores dos centros: trata-se de elaborar o projeto, as hipóteses e questões de pesquisa, buscar financiamento, e fazer parte da análise dos dados. Isso se distingue do que outros colegas brasileiros chamariam de colaboração: "colher DNA do paciente e mandar para um laboratório no exterior para ser analisado". Outra pesquisadora, da mesma instituição, descreve de forma semelhante o que seria de fato uma colaboração:

Eu não sei da experiência que você está tendo com outros pesquisadores, mas eu tive uma formação assim: se eu tenho os pacientes, se eu tenho o DNA dos pacientes, o que é mais fácil? É eu mandar para fora para o pessoal fazer as análises lá fora. E a gente não faz isso. Isso não é colaboração, isso é chupinhação. Eu tenho os pacientes, mas se você quer a colaboração nós vamos fazer aqui as coisas. Isso é colaboração. E aí a gente vai mixar os dados e ver que ganho a gente tem. Esse negócio de eu tenho aqui as pacientes e eu mando os dados para lá para serem processados, aqui no nosso grupo a gente não faz. (...) É colaboração quando você divide as coisas, você não só manda para fazer lá. Porque assim eles trabalham com os dados, têm os dados, ficam com eles, e eles publicam como eles querem, e a gente é sempre coautor (Julia, bióloga, Unicamp).

Aqui há alguns elementos a mais: ao ocuparem o papel de fornecedor de matériaprima, os dados produzidos por pesquisadores brasileiros seriam de posse dos centros e podem ser publicados da maneira que eles acharem melhor. Além disso, destaca-se que entrar como coautor em um artigo em colaboração internacional não é suficiente: é necessário dividir as tarefas, participar da análise dos dados produzidos, enfim, participar efetivamente ou "intelectualmente" - do trabalho de pesquisa. Nesse sentido, para as duas entrevistadas acima, a colaboração efetiva é aquela em que as tarefas a serem divididas vão da concepção do projeto, passando pela coleta de dados, participação na análise, esforço de teorização, publicação até chegar, por fim, à valorização dos resultados publicados. 
Apesar de aparecer com uma certa frequência, o tema do acesso às amostras por parte dos pesquisadores internacionais é tratado com certo desconforto nas entrevistas, e o papel de fornecedor de matéria-prima atribuído ao Brasil é constantemente contestado. Os pesquisadores se dividem entre aqueles que acham que a relação de "exploração" ficou no passado, e os que afirmam que as assimetrias se mantêm até o momento presente, em muitos grupos brasileiros. Abaixo discuto alguns relatos que evidenciam essas relações mais assimétricas. Por exemplo, uma entrevistada descreve da seguinte forma sua experiência em um consórcio internacional:

Deixa eu te dizer uma coisa, bem a verdade. Esse é o tipo da colaboração que eu senti é que nós ficamos sendo considerados muito como o pessoal que mandou as amostras para a matriz. O que eu quero dizer? [Começa a desenhar]. Aqui está a América Latina, a América Latina tem vários países, todos mandando suas amostras para a Inglaterra. Nós, claro, temos todos os dados do Brasil, a Bolívia tem os dados da Bolivia, o Chile tem do Chile, e a Inglaterra tem todos os dados (Rita, médica, UFRGS).

Para além do reconhecimento de um papel mais subordinado, de ser "o pessoal que mandou as amostras para a matriz", há um elemento marcante dessa relação assimétrica: a centralização dos dados de populações de diversos países, coletados a partir de um consórcio sediado na Inglaterra - que financiou parte da coleta e, sobretudo, as análises desses dados em um laboratório do centro. Essa mesma centralização de dados é descrita de modo menos explícito por um pesquisador de Belém, ao falar da colaboração com um grupo estadunidense:

A gente já mandou amostras para eles analisarem lá, daqui de Belém, de coisas daqui de Belém.

Mas aí geralmente é alguma coisa que vocês não conseguem fazer aqui?

Não, é que eles fazem lá, de amostras, por exemplo, de outros países, e, aí, que características tem em Belém? Aí a gente manda para eles fazerem essa análise lá. É uma epidemiologia molecular, mais ou menos.

Então eles vão fazendo de vários...?

De vários locais, isso. Eles têm muitos trabalhos assim, com vários centros, entre África, Ásia... E aqui, no Norte do país, vamos dizer assim, somos nós que estamos com alguns vínculos com esse grupo (Samuel, biólogo, UFPA).

Nesse sentido, pesquisadores do Brasil, da África e da Ásia mantêm colaborações com o mesmo grupo estadunidense, mas só se vinculam entre si por meio desse mesmo grupo, que se torna ponto de passagem obrigatório (Latour, 2000), e acaba por centralizar os dados e levar a cabo análises comparativas, envolvendo amostras de diversos locais do mundo.

Outro elemento de uma relação assimétrica pode ser visto na descrição que uma entrevistada faz, sobre sua colaboração com pesquisadores da Alemanha, que estudam a mesma doença que ela: 
A colaboração com a Alemanha é para estudar modificadores do fenótipo da doença (...). Eles são experts nessa doença, recebem todas as amostras da Europa. E a gente aqui tem quase o mesmo número de amostras que eles têm. Só que há características bem visivelmente diferentes, a gente tem insistido nisso, que a gente tem diferenças. É importante estabelecer coortes de comparação [entre as populações]. E a gente tem feito isso aqui. Não que a gente recebeu deles, eles nunca mandaram amostras europeias para nós [risos], tem uma questão colonialista bem nítida, sabe? A gente pode mandar, mas eles mandar para cá, não... Mas mandar pelo menos os bancos de dados agora eles estão aceitando mais (Ana, médica, UFRGS).

Não fica claro, na descrição da colaboração, se as amostras brasileiras foram enviadas para a Alemanha, mas destaca-se que o inverso nunca aconteceu: apesar de eles solicitarem amostras coletadas por colaboradores de outros países - países das periferias, mas também dos centros, considerando que eles têm "todas as amostras da Europa" -, eles nunca enviaram essas amostras para a pesquisadora brasileira. Note-se o que a entrevistada chama de "questão colonialista": os centros esperam receber das periferias - ou das colônias - as amostras necessárias para uma pesquisa, mas não se cogita que a relação possa ter uma seta inversa, que amostras sejam enviadas para a periferia realizar as análises necessárias e ficar em posse desse material para trabalhos futuros. Parece inegável que o papel de fornecedor de amostras é o que muitas vezes se espera de pesquisadores situados nas periferias:

Dá para perceber quando o colaborador está só interessado na amostra?

$\mathrm{Ah}$, dá [risos]! A gente pode cometer alguns enganos, mas tem uns que são bem claros. Quando começou o negócio do zika, tinha gente que me dizia "preciso de um cérebro com zika". Acho que nem respondi, ou se respondi disse "acho que você não está entendendo muito bem". Tem gente que não diz nem por que quer, não mostra nem o projeto... (Rita, médica, UFRGS).

Fui contactado por um pesquisador muito renomado, quando saiu o "Ciência Sem Fronteiras". Ele falou: "surgiu o Ciência Sem Fronteiras, para a gente seria interessante ter alguém do Brasil aqui, você tem interesse?". "Tenho, maravilha!". Mas como ele chegou até mim? Fiquei me perguntando... O foco dele não era eu, o foco dele era a população brasileira (...). Ele queria fazer o sequenciamento de nova geração de alguns genes nas nossas amostras. Eu estava querendo fazer aqui, e ele disse: "não, aqui nós temos os outros equipamentos". É verdade. Mas, durante essas conversas, a gente falou que estava com dificuldade de conseguir a aprovação do projeto; eu disse que estava com dificuldade, mas nós nem tínhamos entrado com o pedido. Ele falou: "já vai mandando as amostras". Pronto, chegou num momento que não dá mais. Não é errado isso, não é que ninguém faça, você consegue uma aprovação no comitê de ética e você manda. Mas não é meu interesse, eu quero participar ativamente da elaboração dos projetos, da discussão dos dados (Caio, biólogo, USP/RP).

$\mathrm{Na}$ Inglaterra [durante o pós-doutorado], por exemplo, tinha um camarada lá, e notei que ele estava interessado nas amostras dos indígenas. E quando ele viu que eu não ia fornecer amostras, ele simplesmente parou de me 
cumprimentar. Antes ele era todo simpático, cheio de conversa, e de repente percebeu que não ia ter nada em troca... No momento que viu que eu não tinha interesse, e não tinha possibilidade - não é assim, a gente não dá amostra, parecia uma coisa meio colonialista (Vanessa, bióloga, UFRGS).

A presente pesquisa não foi desenhada para responder se essa forma de relação "colonialista" é de fato frequente nas colaborações em genética humana e médica considerando a seleção de apenas quatro instituições de ensino e pesquisa do país e o recurso a entrevistas qualitativas. De toda forma, algo que apareceu em quase todos os relatos é que essa relação deve ser sempre evitada. Esse elemento normativo fica evidente nas respostas a uma questão, feita para a maior parte dos entrevistados, que buscava dar conta, em termos gerais, de quais seriam as características de uma colaboração bem-sucedida - uma "boa colaboração" - e os contornos de uma colaboração a ser evitada - uma "má colaboração".

Entre as expressões mais usadas para definir o que seria uma boa colaboração estão: "aquela que favorece os dois lados", "equilibrada", "de mão dupla", "os dois lados saem ganhando", "quando há uma recíproca", "aquela em que todo mundo cresce junto", "quando todo mundo participa equitativamente", "quando se consegue conversar no mesmo nível", "quando o pesquisador te respeita de igual para igual", "quando existe um intercâmbio de conhecimento entre os participantes de dois laboratórios", "quando há troca de informações livre, e possibilidade de uma certa independência entre os que estão trabalhando em colaboração", "quando a gente pode realmente ter uma participação efetiva na colaboração". Todas essas falas e expressões evidenciam, pelo menos em termos ideais - tal como a pergunta foi formulada - a busca por colaborações em que não haja assimetria muito pronunciada entre os participantes, e que beneficie igualmente as diferentes partes envolvidas.

A má colaboração, por sua vez, é caracterizada por expressões opostas: “assimétrica”, "passiva", "unilateral”, “quando só um grupo fica levando vantagem e o outro só doando sem receber nada em troca", ou "colaboração de mão única" ${ }^{90}$. Tal oposição pode ser identificada na fala de diversos pesquisadores entrevistados:

Uma boa colaboração é uma colaboração equilibrada. É uma colaboração onde tem gente que vai doar a amostra, mas vai participar também do desenho intelectual da pesquisa. Eu acho muito importante essa questão do desenho intelectual: a gente está a todo momento entendendo qual é a pergunta, qual é o desenho experimental, qual é o desfecho que eu vou medir, e limitações e potencialidades do estudo. A má colaboração é a

90 Há outras características de uma "má colaboração": a colaboração que não gera nenhum artigo; aquela que é muito pontual; aquela que nem todos trabalham na mesma medida, ou que alguém não faz o que é combinado; aquela em que esquecem de colocar o nome de alguém no artigo; aquela que alguém exige seu nome no artigo sem ter feito nada, ou quase nada; quando roubam uma ideia; quando os objetivos não estão claros para todo mundo etc. Tais características não serão abordadas aqui. 
colaboração passiva: eu mando os cinco casos que eu tenho aqui para você e você decide o que fazer com eles (Diego, médico, USP/RP).

\section{O que você considera uma boa colaboração científica?}

Aquela que favorece os dois lados sempre, né? Nós somos pequenos, e a ideia é que a gente sempre seja ajudado, mas é importante que nesse caminho a gente também, de certa forma, traga algum benefício a quem nos ajuda, seja da produção conjunta do conhecimento, ou de oferecer peculiaridades que eles não dispõem, nos locais distantes daqui. (...) Mas a gente não pode limitar, nem botar à frente, que a nossa participação numa colaboração é oferecer amostra. Esse sempre foi um raciocínio contra o qual lutamos. A gente tem que participar intelectualmente na produção dos projetos, do conhecimento. É óbvio que a gente precisa muito mais dos avanços tecnológicos, a gente está mais atrás do que os demais, mas, pelo menos intelectualmente a gente tem algo a oferecer, certamente.

No sentido de elaborar o projeto, de...?

Isso. E não só mandar a amostra. A gente tem que participar, aprender o que a gente não souber fazer, e fazer o que a gente sabe (Pedro, médico, UFPA).

A fala imediatamente acima expressa a ideia de como, mesmo que a colaboração tenha um elemento de "ajuda", em que o grupo do pesquisador brasileiro é caracterizado como "pequeno", precisando dos "avanços tecnológicos" dos centros, isso não significa que a colaboração precise necessariamente ser unilateral, ou que o grupo assuma o papel de fornecedor de amostras. Em outros termos, defende-se que é possível - e desejado "participar intelectualmente" dos projetos, mesmo estando na periferia.

Nesse sentido, quando se fala de uma colaboração a ser evitada, a questão das amostras entra em primeiro plano: é preciso fazer colaborações em que se tenha uma "participação intelectual no trabalho", que não seja simplesmente mandar amostras para serem analisadas em outro local, que desenhou a pesquisa, e que tem o controle do trabalho. É nessa chave que devem ser entendidas as reiteradas afirmações de que uma colaboração ideal deve ter "troca", "equilíbrio" e "reciprocidade".

O objetivo de tentar evitar relações de assimetria acentuada é destacado em diversas entrevistas, tanto que há até quem abra mão de colaborações internacionais, como nos exemplos abaixo, em que um pesquisador deixou de fazer um estágio doutoral nos Estados Unidos, e uma pesquisadora afirma não estabelecer colaborações internacionais:

No meu doutorado eu cheguei a sentar e conversar com um professor dos Estados Unidos (...), ele me aceitou de imediato. A gente recuou. Por quê? É uma coisa assim muito da minha formação, eu acho que a gente tem uma riqueza muito grande aqui, que é o nosso material biológico. Eu não compactuo com colaborações internacionais onde você está indo simplesmente para levar amostra, e eu fiquei com essa percepção: eles estavam me aceitando porque eles tinham interesse nas nossas amostras (...). Isso é uma coisa que para mim é fundamental: "você está interessado na nossa colaboração científica, nós vamos trabalhar colaborando, ou isso é um 
trabalho onde você vai como último autor, meu aluno entra, eu entro aqui no meio, e nós não estamos dando contribuição?” (Caio, biólogo, USP/RP).

E [colaborações] internacionais não tenho experiência, nunca procurei muito, porque eu vejo, assim, que os pesquisadores de ponta, quando eles olham para a gente, é só: me manda as amostras. E a gente manda as amostras e fica sendo um exportador de material. Não é um trabalho efetivo. A colaboração é muito direcionada para os interesses deles. Eu sempre vi assim (...). Eu estou em um consórcio internacional, a gente mandou as amostras, mas o acesso é muito limitado.

\section{Mas em que sentido? Você não tem amostras de todas pessoas?}

É tanta regulamentação que eles criam, para ter as licenças para ter acesso ao resultado final, que no fim eu vejo que a gente é um pouco usado, é essa a sensação que me fica. Então não me empenho muito em colaborações internacionais. Se alguém me convidar provavelmente vou aceitar, mas não me empenho muito em procurar (...). Eu não gosto da ideia de ser subalterno a pesquisadores do primeiro mundo (Débora, bióloga, UFRGS).

Os dois casos acima apontam para dificuldades em realizar colaborações equilibradas em situações percebidas como de interesse claro e direto nas amostras, com pouca contrapartida - e pouco espaço - para uma participação efetiva. No primeiro exemplo, a percepção de que o colaborador internacional não estava interessado em sua expertise, mas sim nas amostras armazenadas pelo seu grupo, fez com que o pesquisador abrisse mão de realizar o estágio doutoral em uma instituição prestigiada, mesmo que essa estadia pudesse, em princípio, incrementar seu currículo. No segundo exemplo, tem-se a participação em um consórcio internacional que não é vista como benéfica pois, apesar de as amostras brasileiras terem sido incluídas no banco de dados do consórcio, o acesso as outras amostras teoricamente disponíveis - dependia de regulamentações e licenças que, na prática, quase impedem o acesso, fazendo inclusive com que a pesquisadora repensasse a importância de buscar colaborações internacionais.

Outra pesquisadora - falando da inserção internacional das pesquisas brasileiras em genética médica - destaca que, ainda que o que se espera de países como o Brasil seja o envio de amostras, ao aceitar esse modo de se relacionar com laboratórios dos centros, o pesquisador brasileiro nunca adquirirá autonomia para realizar suas pesquisas:

Esse negócio de ficar colaborando, ficar mandando material continuamente é difícil... Um grupo, por exemplo, de neurologistas, numa certa cidade do país, jamais mandou material para nós, manda direto para os norteamericanos. O que aconteceu? Nunca desenvolveram nada nessa cidade. E quando termina o recurso, ou quando o cara americano não quer mais colaborar, eles não conseguem mais fazer os seus diagnósticos. Isso foi ruim para eles, e de certo modo está todo mundo vendo isso, inclusive os norteamericanos (Ana, médica, UFRGS). 
A busca de uma certa autonomia - o que implica, na fala acima, não depender completamente de colaborações internacionais, de modo a conseguir implementar localmente a infraestrutura para pesquisa e diagnóstico de pacientes - é algo muito prezado e enfatizado pelos entrevistados. Os pesquisadores afirmam, então, que é necessário buscar colaborações que evitem esse papel de dependência extrema de um grupo em relação aos centros.

Me daria uma certa tristeza em pensar, daqui a 10 anos, se eu olhasse para trás e falasse 'poxa, a gente publicou, a gente foi para fora, a gente fez um monte de coisa na Dinamarca e na Holanda, mas a gente não implantou isso aqui'. Tudo bem que a gente tem questões financeiras importantes no Brasil. Mas, no que não depender exclusivamente de muito financiamento, eu acho que o maior desafio é implantar, trazer esse conhecimento para cá. Isso é uma boa colaboração científica: a gente ter esse retorno, de ir, adquirir o conhecimento, implantar aqui, e depois não depender exclusivamente do conhecimento, da infraestrutura e da tecnologia dos dinamarqueses e dos holandeses, a gente conseguir reproduzir isso aqui (...). Acho que a gente tem que ter um certo cuidado em não ficar eternamente dependente da tecnologia ou do conhecimento do exterior (Danilo, biólogo, Unicamp).

Retoma-se, com isso, a discussão realizada no capítulo anterior, no que concerne à importância conferida ao aprendizado com pesquisadores e laboratórios centrais e, principalmente, à implantação, no contexto local, do que foi aprendido (ou, em outros termos, a importância conferida à transferência de tecnologia). A fala acima evidencia, também, que, em um contexto de falta de financiamento talvez nem tudo que foi aprendido possa de fato ser implementado localmente, mas que, mesmo assim, é necessário o esforço de tentar reproduzir o que for possível, de modo a não ficar "eternamente dependente" da colaboração.

Uma pesquisadora de Porto Alegre, ao ser perguntada sobre a não realização de nenhuma etapa de sua formação no exterior, explica da seguinte forma suas motivações:

A minha formação foi toda no país. Não sei te dizer porque que eu não saí, tem várias coisas (...). Também não é tão importante para a minha vida, eu não me ressinto disso. Porque depois que eu me estabeleço como professora e pesquisadora é que eu realmente faço as interações com o exterior, e elas são muito boas, e são muito mais horizontais do que talvez fossem se não tivesse sido assim. Quer dizer, as parcerias que eu tenho hoje são horizontais, e não fui eu que busquei, foram os estrangeiros que buscaram. Eu não fui fazer formação lá fora, mas eu não vim frustrada para cá, sem poder fazer colaborações. Não, eu fui montando as coisas aqui. A gente sempre tentou fazer tudo in house, tudo em casa, dificilmente eu mandei material de muita gente para o exterior para fazer as investigações lá, só os primeiros, do doutorado, enquanto montava a técnica aqui. (...). Tu me entende? Não é assim "eu vou mandar para lá, porque aí ele faz o diagnóstico dos meus pacientes, aí depois entra como um paper, e assim por diante". Não, isso não. E por que a gente teve esse gosto, essa teimosia? Eu acho que é porque eu tenho uma coisa meio nacionalista, mesmo, eu achava que a gente tinha que montar as coisas aqui, tinha que ter autonomia, tinha que colaborar com a construção das competências técnicas locais (Ana, médica, UFRGS). 
A preocupação geral dos pesquisadores entrevistados é que as colaborações internacionais, principalmente quando pensadas em termos de aprendizado-implementação, devem servir para a independência e o desenvolvimento locais. Diante de diversas dificuldades descritas no capítulo anterior - periferia pensada em termos de falta -, o aprendizado ganha uma dimensão nacionalista, uma preocupação em comprar os equipamentos e implantar as técnicas no país, inclusive para poder atender os pacientes brasileiros acometidos por doenças genéticas. São colaborações internacionais que têm uma dimensão nacional no horizonte, para além, inclusive, de suas carreiras individuais, tanto é que por diversas vezes os pesquisadores afirmam que de nada adianta que a colaboração resulte em uma publicação, se o pesquisador não participou do trabalho, não "aprendeu", não implementou, não auxiliou na construção do conhecimento:

Uma última questão, no que diz respeito à discussão sobre o possível papel do Brasil como fornecedor de amostras, diz respeito à possibilidade de negociar uma participação mais ativa na colaboração, mesmo que de início não fosse essa a relação esperada, por parte dos pesquisadores dos centros:

Eu acho que [em uma colaboração] tem que haver participação intelectual. Eu sempre fui muito insistente, nada desse negócio "você colhe os pacientes e manda para a gente, a gente faz análise". Porque tem grupos que te propõem isso, as pessoas não se sentem inibidas de propor. Mas aí você fala: "assim eu não estou interessada". Não estou interessada em ter uma participação apenas de - é como eu chamo - fornecedor de matéria-prima. $\mathrm{O}$ termo deixa bem claro, né? $\mathrm{O}$ meu grupo não precisa disso, nós estamos interessados em contribuir intelectualmente para o trabalho.

\section{É fácil perceber que a colaboração que estão procurando é desse tipo?}

É fácil, porque ele vai falar assim "só colhe as amostras e manda, que a gente analisa aqui”. Na verdade, é fácil se você está há tempo suficiente nesse business (...). E você tem que se sentir bem seguro do que você quer na colaboração. Pessoas que não têm segurança do que querem em uma colaboração podem ser enganadas mais frequentemente. Acho que se você está bem seguro do que você quer, do que é importante para o seu grupo, você consegue, às vezes, até negociar. Existem situações em que eles falam "manda", você diz "mandar não vai ser", e o grupo volta atrás: "então vocês participam". Porque às vezes não é que o outro está agindo de má fé, é que é essa a maneira com que ele está acostumado (Sofia, médica, Unicamp).

Quando se trata de trabalhar com pesquisadores em outros países, considerados mais avançados ou desenvolvidos, os entrevistados relatam, então, algumas estratégias de negociação com aqueles que, em um primeiro contato, parecem só estar interessados nas amostras de seus pacientes ou das populações indígenas. Considerando que os entrevistados se dizem não interessados em realizar esse tipo de colaboração unilateral, buscando participar "intelectualmente" da pesquisa, no momento do contato passa-se a negociar os termos da 
colaboração, que inclui definir com clareza os objetivos da pesquisa e o que se espera da parceria em desenvolvimento.

Imagino que vocês sejam bastante solicitados por outros pesquisadores,
porque vocês têm amostras que as pessoas lá fora invejam. Bastante. Mas é uma má colaboração, que só quer amostra, e isso eu não faço. Sou até capaz de pedir permissão para sair com a amostra, mas eu retorno com ela e vou fazer só aquilo que foi o acordo. Não dou amostra por dar. E quem já me conhece nem pede porque eu acho que não é porque você está no Brasil, porque você está na Amazônia que você tem que fazer isso, você tem que seguir as regras, como em qualquer país. Não vou citar nomes mas, recentemente, numa das colaborações internacionais eles queriam que eu só enviasse amostra e eu disse não. Disse que eu faria um acordo, eles concordaram, e o acordo tem solicitações daqui e de lá (...). Eu faço o acordo, cumpro, vamos usar as amostras para essa finalidade específica que eu aprovei no comitê de ética. Mas eu quero aprender e quero voltar com essa expertise para implementar no meu laboratório (Aline, bióloga, UFPA).

Aqui trata-se de um outro tipo de negociação: ainda que se cogite levar a amostra para um centro de pesquisa no exterior, a "guarda" da amostra permanece no Brasil: elas serão utilizadas para uma finalidade específica, e trazidas de volta ao fim daquele projeto. Ao mesmo tempo, há, como dito, uma grande preocupação em aprender "essa expertise", para que ela seja posteriormente implementada no laboratório, permitindo que, nas próximas vezes, o trabalho seja feito localmente, mesmo que no registro de colaborações internacionais futuras. De toda forma, é bastante ressaltado que a necessidade de combinar muito bem a divisão de tarefas e as responsabilidades de cada um, fazer um "acordo", com "solicitações dos dois lados" para que não haja imprevistos posteriormente. Entre as "surpresas" relatadas, há casos de trabalhos que simplesmente não aconteceram:

Uma vez eu mandei um material para um grupo lá da Europa, especialmente um pesquisador da Europa, ele analisou os dados, tabulou os dados, tudo, estava tudo direitinho. Aí eu escrevi o artigo, mandei para ele, e ele nunca respondeu. Então não pude publicar (Joaquim, biólogo, UFRGS).

Tem um outro grupo que propôs estudar a origem ancestral de uma doença chamada (...). Ficamos muito animados. Mandamos 50 amostras, até hoje nada, três anos de silêncio sepulcral. É o risco de tu mandar amostra para o exterior, para um laboratório que não é teu, sem algo formalizado, sem um contrato, não um contrato, uma colaboração formalizada, por agências de fomento, que está reconhecida (Ana, médica, UFRGS).

Outra preocupação, já evidenciada anteriormente, é de que se realizar algo com as amostras sem o consentimento do pesquisador brasileiro. Aqui os relatos são bastante escassos: uma única pesquisadora relata um caso parecido e, de certa forma, atribui o fato a uma falta de combinação prévia e clara na colaboração: 
Agora, tu mandar as coisas sem combinar, isso é uma coisa que acontece quando a gente talvez seja um pouco - deixa eu pensar uma palavra delicada - inexperiente. (...) Realmente, mandar material sem combinar o que vai, no mínimo, ser feito com o material é muito ruim, o material é teu. Não sei, eu não estou lembrando de ninguém que a gente tenha claramente percebido que o que fizeram com as amostras que foram para fora não tinha sido combinado. É, teve sim [risos]. (...). Mas eu errei porque eu tinha que ter dito 'olha, se você for fazer outra coisa você tem que me avisar'. Também é papel da gente se posicionar, ter postura (Ana, médica, UFRGS).

A pesquisadora aponta que a falta de negociação de acordos claros abre espaço para potenciais tensões com os colaboradores estrangeiros. Ao mesmo tempo, é possível refletir, a partir de exemplos como esse, acerca do papel esperado do colaborador brasileiro: que forneça as amostras, sem muitas restrições, sejam formais ou informais, evidenciando aspectos de uma relação assimétrica. Em princípio, espera-se que ninguém faça nada com os dados que não tenha sido previamente combinado, tal como ilustrado por exemplos, trazidos nesta tese, de pesquisadores brasileiros que não conseguiram publicar dados produzidos em colaboração internacional, por não terem obtido autorização expressa de seu colaborador estrangeiro. Porém, na relação inversa, o colaborador estrangeiro utiliza a amostra sem pedir autorização prévia, mas esse fato não é interpretado como uma quebra de confiança na colaboração, e sim como responsabilidade da própria pesquisadora entrevistada, que afirma ter errado ao não se posicionar mais assertivamente.

Se os pesquisadores afirmam que é possível negociar uma maior participação em colaborações que, em princípio, são desenhadas a partir do papel do Brasil como fornecedor de matéria-prima, há um segundo tipo de negociação, em que as amostras entram como estratégia para o estabelecimento de colaborações internacionais. Elas são usadas ativamente, de forma a viabilizar uma determinada pesquisa no exterior:

Meu doutorado era com índios, e em parte eu usei isso, "eu trabalho com populações indígenas, eu tenho as amostras". Na época eu já tinha todas as autorizações, todas as questões éticas pertinentes (...). Facilitou muito, porque eles tinham interesse em trabalhar com isso. Com Ribeirão Preto foi a mesma coisa, fui para trabalhar com populações indígenas, e o [orientador] queria trabalhar com essa área, então nós tínhamos algo que interessava a ele. Se nós não tivéssemos, ia ser mais difícil. Se fosse só a minha mão, a minha cabeça, talvez tivesse um cara lá do lado que trabalhasse melhor do que eu. Isso facilita um pouco, porque a internacionalização é uma relação de troca, e às vezes a gente tem pouca coisa a oferecer, exceto coisas que são só nossas, e isso entra na negociação (Lucas, biólogo, UFPA).

As potenciais vantagens de ter amostras de populações indígenas são, nesse exemplo, mobilizadas pelo pesquisador tanto para estabelecer uma colaboração, durante o doutorado, com pesquisadores da Alemanha, quanto no mestrado, realizado na USP de Ribeirão Preto. 
Em um ambiente em que várias pessoas competem por um posto em um determinado laboratório, a posse dessa vantagem pode significar uma aceitação facilitada.

O primeiro tipo de negociação, descrito mais acima, ocorre quando os pesquisadores brasileiros são procurados por seus pares internacionais, enquanto o segundo retrata uma estratégia dos pesquisadores brasileiros de iniciar, estabelecer e desenvolver colaborações internacionais. Nesse sentido, fornecer amostras para pesquisadores estrangeiros é uma parte importante na relação de colaboração, e na estadia nos laboratórios dos centros, evidenciada inclusive no primeiro capítulo, a partir da reconstrução do processo de institucionalização da pesquisa em genética. Ao mesmo tempo, se esse é um dos elementos, não é o único. De um lado, é possível pensar em termos de exploração, de fornecimento de matéria-prima para os centros; de outro, em termos de estratégia, de um caminho para trajetórias de colaboração, em que é possível negociar e em que alguns pesquisadores brasileiros podem, inclusive, ter grande êxito individual, como será visto mais à frente, ou, ao menos, aprender e implementar localmente aquilo que foi aprendido graças à colaboração.

\subsection{Construção de uma agenda de pesquisa periférica}

As amostras são, também, uma dimensão relevante da construção das agendas de pesquisa locais. Um elemento importante da construção de tais agendas foi discutido no primeiro capítulo desta tese e diz respeito à tradição local da área, formada pela ideia de uma não competição com temas e agendas que são considerados de difícil acesso ou muito concorridos. Essa mesma dinâmica foi verificada no presente, em que pesquisadores entrevistados descrevem, de forma semelhante, seus objetivos e questões de pesquisa:

Que questão dentro da genética humana e médica você quer responder? Dentro daquela perspectiva em que eu não posso competir com quem está fazendo trabalho de ponta; os grupos internacionais têm tecnologia, têm insumos, e têm gente para trabalhar, é impossivel imaginar que eu vá competir para ser prêmio Nobel, etc. Mas tem algumas coisas que nós temos acesso, e que eles não têm, no caso de estudos populacionais, que me permitem, usando tecnologias que estão disponiveis, tentar responder. $\mathrm{E}$ o que eu quero responder? Quero identificar genes, ou seja, mutações que possam explicar essa aparente mudança de perfil epidemiológico dos indígenas, quando eles começam a apresentar uma série de doenças crônicas que, aparentemente, têm uma causa genética subjacente. A oportunidade de estudar isso poucas pessoas têm, e nós temos. Então nesse nível eu acho que a gente pode dar uma contribuição importante (Matheus, médico, UFPA).

É possível pensar a posição em termos de estratégia, quando se busca questões que podem ser respondidas com os recursos disponíveis no contexto local, notadamente amostras 
da população brasileira, e, principalmente, que são favorecidas por esse mesmo contexto local, no sentido de "oportunidades" que seriam mais restritas para os pesquisadores de fora do país. Ao mesmo tempo, destaca-se que essa estratégia não permite disputar o prêmio Nobel, consagração máxima no espaço científico, mas sim realizar pesquisas que seus pares situados em outros contextos não terão condições de realizar. Nas entrevistas há outros exemplos de agendas de pesquisa estabelecidas a partir dessa noção de "oportunidade":

A escolha [do tema] em boa parte foi influenciada pelo [pesquisador estadunidense]. No final do meu estágio de um ano lá [nos Estados Unidos], eu perguntei o que, na opinião dele, eu deveria fazer, e ele disse que estrategicamente a melhor escolha seriam os ameríndios, porque eu estava perto deles, e poderia, com muito mais segurança e facilidade, trabalhar com eles, do que um estrangeiro. Além disso era uma população ainda pouco estudada do ponto de vista genético (Joaquim, biólogo, UFRGS).

E outra coisa muito importante é que a gente acaba trabalhando muito com amostras de conveniência, nós temos aqui o estoque mais rico de amostras de nativos americanos do mundo, e com parecer do Conselho de Ética para uso em estudos evolutivos. Quem é que tem que estudar os nativos americanos de tribos brasileiras? Os brasileiros! Os outros não têm nem acesso a isso, tem que ser a gente. É uma questão de oportunidade, uma questão de saber o que é relevante no mundo científico, quer dizer, tem uma quantidade de informação astronômica sobre populações continentais, europeus em especial, bastante coisa sobre africanos do Saara. E quem vai estudar os nativos americanos? Tem que ser nós, se não fica um grupo inteiro populacional negligenciado com relação ao entendimento sobre o perfil genético, sobre a história... (Vanessa, bióloga, UFRGS).

É possível aqui enfatizar dois elementos. De um lado, tem-se a questão da "facilidade", nesse caso entendida como proximidade geográfica, que torna o tema de pesquisa atraente e viável. Ao mesmo tempo, não se trata apenas de comodidade, considerando que nas duas falas acima é evidenciada uma ausência desse tipo de estudo, e constrói-se a necessidade - e a importância - de pesquisas com "grupos populacionais" ainda não estudados do ponto de vista da genética. A construção de uma agenda de pesquisa, nesse contexto, alia a facilidade de acesso à originalidade da pesquisa. Essa articulação é bastante destacada também no relato abaixo, de uma pesquisadora descrevendo seu grupo de pesquisa:

A gente tem grupo forte em genética de populações nativas, talvez o mais forte do mundo seja aqui. Temos grupo forte em doenças tropicais, eu estou fazendo parte de um grande consórcio, agora, envolvendo o zika vírus (...). Então nessa parte envolvendo doenças tropicais, animais nativos, povos nativos, dinâmica de mestiçagem (tudo relacionado com suscetibilidade diferenciais envolvendo dinâmicas de mestiçagem), nisso os brasileiros são muito fortes, porque se aprendeu a explorar coisas que ninguém mais vai fazer. Em tudo que a gente pode ser original, que eles não têm acesso, às amostras, ao conhecimento... (Vanessa, bióloga, UFRGS). 
O destaque conferido à originalidade das pesquisas no contexto local caminha junto com uma noção de não competição direta com outros centros de pesquisa. Mais acima, destacou-se o relato de uma pesquisa que pode dar uma "contribuição importante", a partir do estudo do perfil epidemiológico dos indígenas, mas que não ganhará o prêmio Nobel comparação pensada aqui no sentido que não terá grande destaque e impacto na comunidade internacional da genética humana e médica. Abaixo, a opção por uma não competição direta é retratada de maneira mais explícita:

Se você olhar para a genética médica inteira, em qual posição vai aparecer o Brasil? Ele está lá embaixo; não lá [ênfase] embaixo, mas não está entre os primeiros (...).

E você acha que vale a pena tentar competir?

Não. O objetivo não tem que ser competir nisso, a gente tem que fazer as coisas corretas e explorar problemas originais, com originalidade. Não posso fazer um projeto que dependa de mil exomas, não posso. O que eu vou fazer? Vou fazer alguma coisa que eu consiga dar respostas importantes, usando a nossa realidade (Rita, médica, UFRGS).

Em um contexto de falta - em que não é possível fazer um projeto que dependa do sequenciamento de mil exomas - é possível fazer pesquisas usando a "nossa realidade", que podem, também, fornecer respostas importantes, seja do ponto de vista científico, seja do ponto de vista da assistência, como será visto mais à frente.

Atá aqui destacou-se a questão da facilidade e originalidade pensando nas pesquisas com "populações nativas", mas o mesmo vale para a genética médica, como pode ser visto nos relatos abaixo:

A gente não tem aqui nenhuma concessão para conseguir as coisas mais rápidas. Isso torna o processo demorado e nisso a gente perde para um concorrente internacional. Um grupo localizado na Inglaterra, nos Estados Unidos, se tem uma ideia parecida com a nossa, a gente acaba perdendo nessa corrida, de quem descobre primeiro. Isso exige do pesquisador brasileiro muito mais criatividade na hora de pensar a sua pesquisa.

\section{Criatividade em que sentido?}

Tem que ser alguma coisa que tu não vá competir direto com os grandes grupos, senão a gente vai perder sempre (...).

\section{Você teria algum exemplo?}

$\mathrm{Na}$ minha área, a gente acaba fazendo muito mais pesquisas clínicas, porque a gente usa, digamos assim, o material dos pacientes. Se a gente for fazer muita pesquisa básica, os grupos de primeiro mundo vão ter mais vantagens porque eles têm mais possibilidades de conseguir equipamentos. Se você pegar um modelo experimental, ele vai ser o mesmo modelo aqui e lá fora, enquanto que com a amostra de pacientes pode ser diferente o nosso resultado porque é uma amostra da nossa população, que provavelmente vai ser diferente das populações de outros lugares. Isso torna um pouco mais único. Precisa ter um pouco de criatividade, e a gente precisa ter uma certa noção sobre o que a gente pode competir e o que a gente não consegue competir (Erica, bióloga, UFRGS). 
Como visto no capítulo anterior, as limitações financeiras e os entraves burocráticos são percebidos como fortes limitadores da possibilidade da pesquisa brasileira em genética humana e médica participar da - e ganhar a - competição pelas descobertas. Nesse caso, tratase, então, de deslocar a corrida, de participar da produção global de conhecimento a partir das amostras locais, que tornam os achados de pesquisa mais "únicos", uma "originalidade" ligada à posse de material empírico singular. Mais do que isso, a pesquisadora aponta que é preciso saber - e perceber - em que espaço é possível competir, e, ao contrário, que temas ou modalidades de pesquisa não vão gerar bons frutos, tendo em vista o contexto local. É possível pensar essa posição, presente não apenas nessa fala, mas em diversas outras entrevistas, em dois sentidos diferentes. O primeiro, em termos de autoexclusão, uma renúncia à participação na competição. Porém, considerando a existência de um campo de produção do conhecimento hierarquicamente estruturado em centros e periferias, a posição expressa a capacidade de enxergar a hierarquia com clareza, identificando os espaços em que é possível se inserir, e aqueles em que as condições da realização da pesquisa brasileira tornam as possibilidades de inserção muito difíceis, senão impossíveis.

Revela-se também presente, nesse modo de ver, uma distinção entre pesquisa básica e pesquisa aplicada, em que a primeira é vista como mais difícil de ser realizada - de forma competitiva - no contexto local, porque se trabalharia com as mesmas questões, necessitando de equipamentos sofisticados e de uma velocidade de obtenção de materiais que colocaria os pesquisadores dos centros em grande vantagem. Já a pesquisa aplicada, fundamentada sobre o "material dos pacientes", que não está disponível para todos, poderia trazer contribuições científicas que não poderiam ser obtidas por esses mesmos pesquisadores dos centros. Nesse sentido, abaixo, há alguns exemplos de pesquisas elaboradas dessa maneira, a partir do material de pacientes locais, que permitiram a descoberta de síndromes genéticas raras, que ainda não haviam sido "caracterizadas" - as mutações genéticas a elas associadas ainda não haviam sido descritas na literatura:

Eu já vi em grupos que identificam novos genes que são responsáveis por determinadas síndromes genéticas. Então alguns trabalhos importantes foram publicados aqui, dada a ocorrência alta de uma síndrome genética ainda não caracterizada. Você, em um atendimento a um paciente, a uma família, começa a identificar um fenótipo, uma síndrome que ainda não foi caracterizada, essa ocorrência em algumas famílias aqui - diferente de outros países, por exemplo - permite a identificação de algumas mutações genéticas associadas a síndromes raras (Carolina, bióloga, USP/RP). 
Acho que o fato de trabalhar, na genética médica, com a lógica das doenças raras, permite que você tenha impacto, com pouco recurso, então a gente tem visibilidade. (...). Acho que a gente tem impacto, na lógica das doenças raras, descrevemos bem coisas muito raras e que vão ter impacto porque não tem outra pessoa descrevendo. (...). Na genética clínica, que é mais para descrever as doenças raras, acho que a gente já teve um impacto muito bom, principalmente na fase clínica, de menos recursos, precisava ter uma pessoa muito capacitada, com capacidade para trabalhar e fazer investigação, e com recursos técnicos que não eram absurdos (Artur, médico, USP/RP).

Articula-se, na fala acima, uma agenda de pesquisa ao defender a possibilidade de realizar, na "lógica das doenças raras", uma pesquisa com algum "impacto", ou relevância, sem serem necessários recursos financeiros de grande monta. Nesse sentido, nos dois grandes conjuntos de temas - genética de populações e genética médica - é possível elaborar um projeto de pesquisa que busque usufruir de certas especificidades do contexto local. É importante destacar que essa articulação não é uma caraterística exclusiva da pesquisa em genética humana e médica brasileira. Anne-Marie Moulin (2008), analisando a pesquisa biomédica no Marrocos, descreve uma rede de grupos de pesquisa que trabalha em torno de doenças genéticas, em particular ataxias familiares e distrofias musculares, e que a partir de um rico material clínico, fornecido por numerosas famílias consanguíneas, obtido a partir de um modelo de pesquisa ligado à assistência, conseguiu descrever síndromes genéticas inéditas e contribuir para o aperfeiçoamento de diagnósticos. A autora atribui o sucesso dessa rede que acumula boas colaborações internacionais, apresenta alta procura por parte de jovens pesquisadores, possuindo índice de publicação razoável e equipamento acima da média do país - justamente à escolha de uma estratégia de pesquisa baseada em um material clínico excepcional, que lhes permite "cortar caminho" nas descobertas científicas (Moulin, 2008).

Os exemplos acima geralmente emergiram no momento da entrevista em que é perguntada a opinião dos pesquisadores sobre o espaço ocupado, no cenário internacional, dos trabalhos desenvolvidos em genética humana e médica no Brasil, o que evidencia o caráter estratégico dessa busca, como uma forma de inserção e diferenciação em um ambiente científico internacional marcado pela competição entre agentes com recursos desiguais.

Falando especificamente da genética humana e médica, acho que muito do que o Brasil oferece como conhecimento, como contribuição, e é conhecido lá fora por isso, vem das particularidades que a gente encontra em determinadas doenças que a gente tem no Brasil. Vou te dar um exemplo, voltado para a minha área: aqui no Brasil a gente tem uma frequência muito elevada de um tipo de câncer específico que é o adenoma carcinoma de adrenal. É um tumor raro, mas quando você observa a frequência dele em todos os outros países, ela é muito baixa, e aqui no Brasil ela é altíssima. Investigando o porque disso, os pesquisadores brasileiros identificaram uma 
mutação genética específica, em um gene específico. Isso foi feito aqui no Brasil. E isso tem um impacto muito grande lá fora, porque você vem de uma particularidade, que acontece aqui, foi desenvolvido e caracterizado por pesquisadores brasileiros, e alguns desses pesquisadores brasileiros inclusive estão agora radicados no exterior (Carolina, bióloga, USP/RP).

Tem-se uma particularidade, um tipo de tumor raro, mas que é menos raro no Brasil, se comparado a outros países, e que por isso pode ser estudado no contexto local, lançando mão de duas facilidades: de um lado, amostras para serem analisadas, e, de outro, pouca competição de grupos estrangeiros, considerando principalmente a raridade do tipo de tumor. Evidentemente, o sucesso desse tipo de empreitada depende da existência de condições para a realização da pesquisa, nos moldes internacionais - o que inclui técnicas, metodologias e equipamentos atualizados que, nesse caso, possibilitaram a identificação de "uma mutação genética específica, em um gene específico". A entrevistada destaca que essa pesquisa teve grande impacto internacional e um dos indicadores utilizados para evidenciar o reconhecimento internacional dessa investigação em particular é o fato de alguns dos pesquisadores envolvidos terem sido absorvidos por laboratórios centrais.

Essa é uma dimensão importante das relações entre centros e periferias, a de que o reconhecimento da pesquisa brasileira ocorre no nível individual: ao realizar a pesquisa que tem impacto internacional, a principal consequência, em termos de reconhecimento, é a absorção dos pesquisadores responsáveis pela descoberta em laboratórios de países centrais. Em uma estrutura assimétrica de produção do conhecimento, que dinamiza a distinção entre centros e periferias, o reconhecimento da excelência na periferia ocorre na dimensão individual. Nesse sentido, é possível pensar menos em termos de reconhecimento da pesquisa brasileira em genética humana e médica, como um todo, e identificar mais no reconhecimento da excelência de pesquisadores individuais, que são então incorporados pelos centros e assim deslocados de seus contextos locais. A reprodução da hierarquia do sistema confere caráter paradoxal a essa modalidade de reconhecimento que, se expressa certo nível de progresso da pesquisa na periferia do sistema científico, tem por consequência retirar o pesquisador reconhecido de seu grupo local, deslocando-o para um centro. Desse modo o progresso da ciência na periferia acaba levando ao fortalecimento dos grupos nos centros (e à correlata retirada de bons recursos dos grupos periféricos) ${ }^{91}$.

91 Ao mesmo tempo, dois entrevistados destacam que a inserção permanente de pesquisadores brasileiros nos centros muitas vezes pode abrir espaço e facilitar colaborações internacionais, entendidas como colaborações com laboratórios no exterior, em que estão alocados pesquisadores brasileiros. 
A posse de amostras, a existência de particularidades locais ${ }^{92}$, doenças raras, ou outras alternativas de se desenvolver uma pesquisa com "praticidade" - facilidade de acesso e concentração dos dados - e "originalidade", só podem ser aproveitadas porque há uma infraestrutura - e pesquisadores situados em instituições que realizam pesquisa - aptos a usufruir desses elementos.

Se vê muita gente trabalhando em colaboração e se vê muita gente trabalhando em grupos só do Brasil. Os trabalhos que ganharam renome internacional há pouco tempo foram com o vírus da Zika e muitos deles foram só do Brasil. Claro, você pode me dizer que isso não tem nada a ver com ciência, tem a ver com o fato de ser uma doença restrita aqui. Mas se nós não estivéssemos preparados, nós enquanto comunidade científica brasileira, para ver a situação, interpretar, não teria sido publicado. Claro, é algo geograficamente restrito, mas tem também a competência das pessoas que souberam olhar, avaliar e explicar cientificamente aquilo (...). O que comentei foi mais a questão da microcefalia, que foi detectada aqui. Por que foi detectada aqui? Porque tinha um grande número de pacientes, claro. Mas isso só pôde ser publicado, avaliado e analisado porque tinha uma equipe competente cientificamente para perceber a importância daquele achado (Daniel, biólogo, UFRGS).

O mero acesso às populações, ou, no caso, a um fenômeno que foi "geograficamente restrito", como os casos de microcefalia, não é condição suficiente para realizar uma pesquisa relevante, que possa ser publicada em periódicos de destaque, e com isso ter potencial de ser lida e reconhecida para além das fronteiras do local. É preciso haver pesquisadores bem formados, "cientificamente competentes", interessados e aptos a perceber a importância daquele fenômeno, tanto do ponto de vista "científico", quanto do ponto de vista da oportunidade que ele pode proporcionar, em termos de publicação. Em outras palavras, pesquisadores aptos a enxergar uma oportunidade e se movimentar naquela direção, e tendo condições institucionais, financeiras e de formação, para aproveitá-la - do contrário, apenas seria possível atuar como "exportador de matéria-prima".

$\mathrm{Na}$ literatura que trata da produção do conhecimento científico em contextos periféricos, essa articulação de uma agenda de pesquisa periférica foi frequentemente descrita lançando mão da noção econômica de vantagens comparativas. A teoria das vantagens comparativas foi formulada por David Ricardo e explicada em seu livro "The Principles of Political Economy and Taxation", de 1817. Em termos muito gerais, trata-se da ideia de que cada país deve se especializar na produção de determinado produto, no qual ele é relativamente melhor, ou que consiga reduzir custos para exportá-lo. Em contrapartida, esse mesmo país deve importar mercadorias que não produz ou cujo custo de fabricação é mais

$\overline{92}$ A particularidade não deve ser entendida como aquilo que não há em lugar nenhum, mas uma particularidade em relação aos centros. 
elevado. Subjacente a essa discussão tem-se a ideia de que a especialização e o comércio resultam numa situação de vantagem no quadro da divisão internacional no trabalho:

Os países retardatários deveriam crescer mediante a expansão dos ramos de produção em que eram favorecidos pela geografia e pela geologia. E que, por suposto, eram muito diferentes dos ramos em que os países industrializados tinham vantagens. O livre-comércio entre os países, através do jogo do mercado, levaria cada país a se especializar racionalmente, sendo todas as atividades igualmente geradoras de valor e portanto de utilidade e de bem-estar (Singer, 1998, p. 123).

Reinterpretando essa concepção e tomando-a como inspiração, é possível pensar em uma busca de vantagens comparativas para alcançar uma diferença com os centros, e, portanto, não concorrer com temas e agendas de pesquisa considerados já monopolizados, e em que eles já possuem vantagens. Uma definição da agenda de pesquisa que é feita a partir do contexto local. As características desse contexto local foram elencadas anteriormente: uma população grande - em termos quantitativos gerais e em número de doentes -, uma população variada, do ponto de vista genético, sistema de saúde de abrangência razoável, dados centralizados em "ilhas de excelência", médicos e pesquisadores bem formados - uma medicina extraordinária, clínica, e não na chave especializada, das máquinas, da medicina dos centros -, aptos a trabalhar com "originalidade" a partir dessas características. Nesse sentido, a articulação desses elementos, conjugada à ideia de não competição direta, constitui uma agenda de pesquisa específica na área de genética humana e médica, que se assemelha à busca de vantagens comparativas.

Ao mesmo tempo, as críticas à teoria das vantagens comparativas, também no campo econômico, auxiliam a complexificar a discussão do ponto de vista da produção do conhecimento. Entre as críticas encontram-se aquelas formuladas no contexto da CEPAL, nos anos 1950, por Raúl Prebisch. De forma também muito resumida, destaca-se que a teoria das vantagens comparativas não leva em conta o conjunto de relações entre um centro industrializado e uma periferia, principalmente no que diz respeito ao desequilíbrio causado, na periferia, pela maior propensão a importar bens industriais em relação à exportação de bens agrícolas e minerais. Para economistas como Prebisch e Celso Furtado, o desenvolvimento latino-americano não deveria se resumir apenas à busca de formas mais eficientes de produção no interior de uma estrutura produtiva baseada em vantagens comparativa; era necessário alterar essas estruturas. As características internas da região e a sua particular inserção nas relações econômicas internacionais demandavam mudanças estruturais, a partir de uma ruptura da divisão baseada em trocas de bens primários por manufaturas. 
Nesse sentido, seria difícil falar em "vantagens" da periferia em relação aos laboratórios de pesquisa nos centros, mas em características que permitem participar marginalmente do jogo. Se comparado a outros países periféricos, como visto acima, os pesquisadores brasileiros têm algumas "vantagens" na competição, o mesmo não pode ser dito quando essa comparação é feita em relação aos pesquisadores dos centros. Primeiro, os pesquisadores explicitaram, ao longo de suas falas, algumas desvantagens, como por exemplo, a noção de que é necessário o pesquisador ser muito mais criativo que aqueles localizados nos centros, para conseguir obter uma participação no cenário internacional da genética humana e médica, ainda que na margem; um tipo de pesquisa que complementa, pode chegar a contribuir com conhecimentos específicos, mas que não leva os pesquisadores brasileiros para o centro ou a "ponta" da pesquisa. Devido às relações assimétricas entre centros e periferias, essa participação não significa passar a fazer parte dos centros, ou, em outros termos, romper com uma divisão internacional do trabalho científico estruturada em centros e periferias.

Pensando relacionalmente, pode-se conceber que contextos de falta e peculiaridades locais teriam como se transformar em algo valioso, no sentido de permitir uma participação dessa ciência nacional no sistema de produção internacional. Isto também por que se observa uma combinação de características negativas, de "falta", com características positivas, como a excelência clínica dos médicos brasileiros. Pois, sem os bons geneticistas brasileiros médicos e de populações - não existiria o bom material brasileiro, tratar-se-ia apenas de "abrir" o território nacional para pesquisadores dos centros virem coletar diretamente as amostras. O local acaba, assim, por tornar-se valioso para o centro em virtude de sua combinação dinâmica de progresso e atraso, características positivas e negativas, que, no entanto, não configuram conjuntos fixos de propriedades, mas podem mudar de sinal conforme variam as situações específicas.

\subsection{Justificando uma agenda de pesquisa: "o que funciona em outras populações não} necessariamente funciona na nossa"

Ao articular a agenda de pesquisa, tal como visto acima, são desenvolvidas estratégias que mobilizam as amostras, configuradas em termos de "praticidade", e que permitem desenvolver pesquisas com "originalidade", de modo a deslocar, em certa medida, a competição internacional. Na fala abaixo, há um elemento a mais dessa articulação:

Precisa ter um pouco de criatividade, e a gente precisa ter uma certa noção sobre o que a gente pode competir e o que a gente não consegue competir, por questões tanto financeiras quanto de entraves burocráticos mesmo (...). 
Mas o que a gente tem observado é que nem sempre o que é publicado por eles ["grupos europeus ou americanos"] é válido para outros locais do mundo, devido a características populacionais, por vários fatores. Então a gente consegue, também, dar um outro enfoque mesmo não estando na ponta da corrida (Erica, bióloga, UFRGS).

Está presente, aqui, a ideia de que os achados de pesquisa produzidos pelos centros nem sempre se confirmam, ao analisar as amostras de pacientes de outros contextos, devido "a características populacionais", ou, em termos mais simples, a noção de que o que funciona para uma determinada população pode não funcionar para outra, o que torna pesquisas "locais" relevantes. Tal discussão está presente no trecho abaixo, já mobilizado anteriormente, de um pesquisador da UFPA, descrevendo uma colaboração com um grupo da Inglaterra:

Hemoglobinopatias são doenças que estão no mundo todo, mas têm influências geográficas, étnicas, então há grupos que têm alguns tipos de mutações, outros não têm, e ele trabalhava com essa visão de genética populacional. E quando eu estudei populações indígenas, um dos trabalhos a gente publicou junto com eles, a gente descreveu uma alteração que encontramos em indígenas (...), e eles não tinham acesso a populações indígenas (Matheus, médico, UFPA).

Nessa fala evidencia-se a existência de "mutações" em populações indígenas que não são encontradas em outras populações e por isso são consideradas relevantes, do ponto de vista de uma genética médica populacional, que leva em conta diferenças na incidência de doenças com um forte componente genético e/ou de anomalias congênitas (do nascimento) em diferentes populações, ou estuda populações com alta prevalência de doenças genéticas e/ou congênitas. Uma pesquisadora da Unicamp usa argumento semelhante, ressaltando a importância de estudar diferentes populações humanas:

Porque podem existir situações em que nós vamos ter genes de suscetibilidade que são importantes na população europeia, e não vão ser tão relevantes na população brasileira, ou na população norte-americana. Então quando você identifica um sinal de que alguma coisa está associada, etc., é muito relevante você examinar em outras populações, para mostrar, primeiro, que não é um viés no estudo, e depois para mostrar qual que é a representatividade daquilo em outras populações de outros ethnic background, certo? Não só você quer encontrar alguma coisa, como você quer ver a distribuição daquilo que você encontrou num grupo grande de indivíduos, ou de diversas etnias (Sofia, médica, Unicamp).

Muitas das falas dos entrevistados evidenciam o que seriam lacunas nos estudos de populações, como a pesquisadora de Belém, abaixo, que afirma que os pacientes brasileiros não "estão nos livros de genética clássica", ou, em outros termos, aquilo que é colocado como padrão de um paciente como uma determinada doença, em termos de fenótipo, não necessariamente corresponde àqueles que eles atendem no cotidiano do serviço de genética. 
Por exemplo, dentro do $\mathrm{X}$ frágil tem uma situação que é a variação fenotípica, das características clínicas. O que explica essa variação? A gente está fazendo um trabalho com epigenética para tentar entender por que a gente está vendo variação fenotípica nos pacientes daqui do Norte, que são fenotipicamente, geneticamente diferentes dos pacientes da Europa, que são os que estão nos livros de genética clássica (Monique, bióloga, UFPA).

Ou ainda, o relato de reações adversas não antecipadas "na literatura", quando pacientes com câncer infantil são tratados com um "protocolo padrão mundial", em um hospital da cidade de Belém:

(...) a população indígena é uma população carente de estudos. Primeiro, ela é uma população ímpar no mundo, extremamente diferente, geneticamente falando. E se conhece muito pouco sobre elas. Vou te dar um exemplo, aqui no Hospital (...), que trata câncer infantil, alguns dos pacientes indígenas, quando tratados com o protocolo padrão mundial, apresentam reações adversas não esperadas na literatura. São coisas extremamente diferentes do observado na literatura, e ninguém entende exatamente o porquê daquilo acontecer. (...). Então seria a base de falta de conhecimento dessas populações, em termos de pesquisa em saúde pública delas, que são populações diferentes (Carlos, biólogo, UFPA).

A expressão "protocolo padrão mundial" resume bem o que está em questão aqui: uma valorização crescente da importância de estudar a diversidade genética das populações que, de certa forma, coloca em questão a própria ideia de um padrão mundial. Falando sobre a importância da criação de um consórcio brasileiro, uma pesquisadora justifica da seguinte maneira a iniciativa:

Para a gente é importante ter [dados] da população brasileira, porque é uma população muito miscigenada, uma população muito diferenciada das outras. Então a frequência que existe em uma população, pode não ter na nossa. Então é importante a gente ter o nosso banco de dados. E nesses consórcios que já existem há muitos anos, a nossa população nunca foi contemplada. Então, isso é uma contribuição boa que o Brasil está fazendo e mostra a inserção da pesquisa brasileira, que não é de um pesquisador e nem de dois, mas de um grupo, de vários grupos, mostrando a inserção brasileira na pesquisa internacional (Julia, bióloga, Unicamp).

Explicando a relação entre ancestralidade e medicina de precisão, um pesquisador de Belém afirma que há "mutações" que podem influenciar tratamentos de determinadas doenças e sua compreensão pode permitir o desenvolvimento de alternativas mais eficientes, de acordo com as características genéticas, ligadas à ancestralidade, de um determinado indivíduo.

$O$ que tem a ver, a ancestralidade, com a medicina de precisão? O que acontece é que algumas mutações que são influentes para a medicina de precisão, ou seja, o fato de que aquela mutação pode predispor um indivíduo a um tratamento com a isoniazida, por exemplo, que é um antibiótico usado para a tuberculose, pode predispor ele a não funcionar; um indivíduo, o paciente, João, a não funcionar o tratamento, e o paciente José a funcionar o 
tratamento, isso por uma mutação. Eu estou simplificando aqui, certo? O que isso tem a ver com a ancestralidade? Essas mutações elas variam de acordo com a ancestralidade. (...) Porque algumas mutações destas são mais comuns a determinados grupos étnicos (Carlos, biólogo, UFPA).

Se, de um lado, a justificativa das pesquisas se dá em termos de ausência, ausência de conhecimento sobre determinadas populações - e seu potencial impacto na saúde pública, que não leva em conta diferenças populacionais -, parte dela se liga à ideia de que há diferenças, que muitas vezes não são levadas em conta nas pesquisas.

Essa colaboração com a Alemanha é para estudar modificadores do fenótipo da doença (...). Eles lá são expert, eles recebem todas as amostras da Europa. E a gente aqui tem quase o mesmo número de amostras dessa doença que eles têm da Europa inteira. Só que tem características bem visivelmente diferentes, eles já leram as nossas publicações, a gente tem insistido nisso, a gente tem diferenças (Ana, médica, UFRGS).

Claro que, em geral, a gente encontra um maior número de publicações de grupos europeus ou americanos, mas o que a gente tem observado é que nem sempre o que é publicado por eles é válido para outros locais do mundo, devido a características populacionais, por vários fatores. Então a gente consegue, também, dar um outro enfoque mesmo não estando na ponta da corrida (...). Para as pessoas, não tomarem como absoluto algo que foi publicado em outra população. Na nossa área, na área de genética humana é bastante relevante, pois nem sempre o que é bom para uma população significa que vai ser bom para outra porque pode ter características genéticas diferentes (Erica, bióloga, UFRGS).

É possível afirmar que há um redirecionamento contemporâneo dos estudos genéticos com recorte em populações. Tal guinada já foi analisada por alguns autores e, de certa forma, apresenta uma tensão com momentos anteriores da pesquisa em genética. Junto ao anúncio oficial da conclusão do Projeto Genoma Humano havia uma mensagem, a de que os seres humanos eram essencialmente os mesmos, pois as sequências genéticas humanas são 99,9\% idênticas. Essa mensagem não é exatamente nova: por décadas, a descoberta de que existe maior variabilidade genética "dentro de grupos" do que "entre grupos" foi aceita como evidência de que a espécie humana não estaria dividida em raças, e a conclusão do Projeto Genoma Humano fortaleceu o argumento, afirmando que as diferenças raciais não podem ser discernidas no nível molecular (Koenig, Lee \& Richardson, 2008). No entanto, em uma série recente de artigos, os geneticistas populacionais vêm argumentando que o genoma é a chave para compreender as diferenças biológicas entre as populações humanas. Cada vez mais, a variação genética entre as populações humanas - raças, etnias, nacionalidades - é objeto de grande interesse, e construída enquanto necessidade, em termos de política pública, para mitigar as disparidades de saúde entre populações (Burchard et al., 2003). 
Nesse sentido, a pesquisa genética sobre populações ocorre cada vez mais em um contexto médico. Ao longo de grande parte do século XX, a genética de populações humanas esteve mais intimamente associada aos esforços antropológicos para reconstruir a história da migração humana. Hoje, os objetivos da medicina personalizada e o alívio das disparidades de saúde impulsionam o investimento social na pesquisa genética sobre a variação da população humana. Tem havido, então, uma crescente atenção à diferença populacional na pesquisa genética, vinculada em parte à emergência da genômica de saúde pública. Ou seja, à medida que os testes genéticos se ampliam, revelam-se lacunas no conhecimento médico com base em bancos de dados de mutações conhecidas em populações de risco previamente identificadas em contextos nacionais, como Estados Unidos, Canadá e Europa (Gibbon, 2015). Isso alimenta um foco na identificação de mutações ainda desconhecidas, que podem estar presentes em diferentes contextos nacionais, como parte da tentativa de inserção da genômica na saúde pública.

É possível afirmar, assim, que há uma agenda internacional de pesquisa genômica cada vez mais preocupada com questões de diferenças populacionais associadas à pesquisa genética de doenças como o câncer (Gibbon, 2016). A ascendência genética tornou-se locus de atividade em um amplo campo de pesquisa científica, no qual os limites entre pesquisa em genética médica e genética populacional estão sendo cada vez mais borrados (Koenig, Lee e Richardson, 2008). Se o interesse pela ascendência genética é um componente cada vez mais evidente da ciência genômica e pós-genômica, o significado e as consequências de uma atenção renovada à diferença populacional não são necessariamente homogêneos em contextos nacionais e transnacionais. Sarah Gibbon (2013; 2015), por exemplo, analisa os movimentos para expandir a genética do câncer no Brasil e mostra como eles são influenciados por - e estão em tensão com - agendas internacionais de pesquisa ligadas à diferença populacional. A autora mostra que o argumento de que não se sabe, no Brasil, a contribuição do risco genético para o aumento das taxas de câncer no país, enfatizando os limites dos modelos de risco padronizados internacionais, alimenta a busca e o ativismo de praticantes da genética do câncer brasileira envolvidos na busca de estimativas locais mais apropriadas acerca do risco genético para a população brasileira.

As falas discutidas nesta seção vão nesse sentido, de defender a necessidade de pesquisas com as populações locais, apontando ausências e lacunas do conhecimento produzido pelos centros. Mas é necessário destacar, justamente, que essas "lacunas" são construídas pelos pesquisadores brasileiros, que declaram "a gente tem insistido nisso, a gente 
tem diferenças”. Ou, então, no caso do consórcio brasileiro montado a partir da justificativa de que em outros consórcios internacionais não há os dados de nossa população, cujos estudos ficam negligenciados. Ou, ainda, ao destacar que os pacientes brasileiros não seguem o "padrão" dos pacientes dos livros de referência, nem respondem necessariamente bem a “protocolos padrão mundial”. Desse modo, os pesquisadores entrevistados identificam uma lacuna nos padrões universais, definidos a partir dos dados dos centros, que situa a pertinência e a relevância científicas de suas pesquisas.

\subsection{Reconhecimento de uma agenda de pesquisa: tensões entre a inserção local e o} reconhecimento internacional

O relato, nas entrevistas, sobre a importância de se estudar a população brasileira seja pensada como um todo, seja do ponto de vista regional, sejam as populações indígenas que ocupam o território - se articulou, frequentemente à ideia de uma vantagem comparativa, usar "material nosso", cujo acesso envolve "praticidade", permite responder questões com “originalidade" e publicar trabalhos em revistas de algum destaque. No exemplo abaixo, um pesquisador conta como um caso que apareceu em um hospital de Belém pode dar origem a uma pesquisa que obteve destaque em um congresso internacional:

$\mathrm{Na}$ doença (...) tu tem uma maneira de fazer o diagnóstico, que é diagnóstico bioquímico, tu quantifica uma proteína, se estiver ausente, tem a doença. Esses pacientes, a maioria deles, podem ser tratados com uma terapia de reposição enzimática; tu dá uma proteína que eles não produzem, e aí você evita a baixa hemoglobina, você evita a baixa plaqueta e reduz de fato o baço dele, o baço e o fígado. Tem uma outra proteína que é um marcador para esses pacientes. É essa proteína que eu estava de olho, que eu testei nos índios. (...). Nós pegamos um índio com a doença, há cinco anos, aqui em Belém, ele não era nem de Belém, era do Mato Grosso do Sul. Então fizemos a dosagem da enzima que serve para diagnóstico, e deu zero. "Ah, então eu doso também, a quitotriosidase desse paciente, que é esperado que esteja lá em cima". Sabe quanto deu? Zero. Bom, então, vou fazer molecular do gene, que codifica essa proteína, para ver o que aconteceu. E nós descobrimos que ele tinha uma alteração que inativava a proteína. Para os médicos isso não é muito bom, porque ela era um marcador. Aí o que eu fiz? Eu achei estranho, logo num índio. Falei "vamos pegar as amostras que nós temos aqui (...) e vamos testar isso em duzentos indígenas", de diferentes tribos. Pois bem, $80 \%$ dessas tribos tem a mutação. Isso quer dizer o seguinte: se eu pegar um novo índio, eu não posso usar essa enzima quito, como marcador de monitoramento da terapia. Veja, saiu da básica para a aplicada, aí eu informo ao médico, que tem que pegar outro marcador. Esse trabalho foi premiado em 2011, ou 2012, em um congresso internacional. Por quê? Nesse congresso, estava o cara que clonou o gene da quito, e eu estava no congresso, vendo, e ele disse: "inclusive, a maior frequência dessa alteração, está no Brasil, veja o pôster 36". E eu copiando o que ele estava dizendo, e aí alguém me cutucou e disse: "é o teu pôster". Aí, na outra hora, 
eu fui lá ver o pôster, e estava cheio de gente. E, de fato, a maior frequência dessa alteração está em populações indígenas. Na clínica, os médicos vão dizer "olha, como é índio, talvez ele tenha essa mutação, é bom lançar mão de outro marcador para monitorar o tratamento" (Leonardo, biólogo, UFPA).

O exemplo é longo, mas nele estão presentes algumas dimensões importantes discutidas até o momento. Primeiro, o encontro com o paciente indígena, no contexto do atendimento, que dá origem a uma questão de pesquisa, localizada. Segundo, o acesso a amostras de outras populações indígenas - coletadas anteriormente, na região amazônica, e estocadas em laboratório da UFPA - que permite que a hipótese formulada a partir do primeiro atendimento seja testada em mais 200 indivíduos. A partir daí, tem-se um trabalho que desperta o interesse e é premiado em um congresso internacional e que dificilmente poderia ser realizado por alguém sem esse acesso. Por fim, é um trabalho que marca a existência de diferenças populacionais importantes, que influenciam o diagnóstico, e consequentemente, o tratamento de populações indígenas. Mas há, ainda, um outro elemento nessa fala, que é a justificativa da pesquisa como "aplicada", que pode justamente auxiliar um médico a realizar um teste mais adequado para a confirmação ou não da suspeita da doença. Nesse sentido, aqui a justificativa não é apenas que as diferentes populações precisam ser estudadas, no sentido de uma vantagem para a concorrer no âmbito internacional, mas uma justificativa baseada na saúde pública, na qualidade do atendimento. Ao mesmo tempo, é inescapável levar em conta que a mutação em questão foi descoberta por um pesquisador situado no centro, e que a pesquisa realizada no Brasil amplia, aprofunda, demonstra, mas é posterior ao achado original, não faz parte da corrida pelas descobertas científicas.

Ao perguntar para uma pesquisadora se a pesquisa com diagnóstico molecular era "rotineira" ou se era possível fazer coisas novas, a resposta recorre a uma justificativa semelhante:

É uma pesquisa rotineira, digamos assim. Não sei se rotineira é a melhor palavra, mas eu entendi o sentido da pergunta. Ela não é uma pesquisa de inovação, no sentido de que não vamos fazer um diagnóstico diferente do que as pessoas fazem no mundo, o que eu vou fazer é aplicar para um conjunto de indivíduos aqui, que é diferente de outro lugar, então eu vou ver uma frequência de alterações diferentes, eu vou poder fazer alguma correlação com a maneira com a qual os pacientes, aqui, apresentam sintomas, em relação a outros lugares. Mas, talvez isso não seja o mais importante, é uma pesquisa que é muito translacional e acho que tem um ponto dela que é importante, que não é tanto a inovação, mas é o benefício que ela traz para as pessoas (Thais, bióloga, UFRGS).

Aqui se retoma a ideia que aplicar um diagnóstico a um conjunto de indivíduos que é diferente daqueles de "outro lugar", o que permitirá verificar uma "frequência de alterações" 
diferente. No entanto, a importância desse tipo de trabalho é colocada menos na chave de realizar uma pesquisa inovadora, mas, antes, no benefício aos pacientes, nesse caso articulado ao acesso ao diagnóstico que, como visto no primeiro capítulo, não está disponível pelo SUS. Esse benefício aos pacientes fornecido pela pesquisa é descrito de forma semelhante por outra pesquisadora de Porto Alegre:

Hoje em dia, na verdade, a grande maioria dos meus projetos são nessa área de neurogenética, mas por causa principalmente de demanda.

Mas a demanda é de que parte? Pacientes?

É também pacientes. A gente tem vários trabalhos que são mais trabalhos clínicos que envolvem pesquisa com pacientes, mas não só. Essa é uma das motivações, principalmente por a gente estar ligados a um hospital. Uma das motivações é justamente tentar atender a demanda de pacientes e tentar oferecer alguma coisa, pelo menos o diagnóstico, que às vezes eles nem teriam (Erica, bióloga, UFRGS).

Dois pesquisadores de Belém, que trabalham com mutagênese ${ }^{93}$, descrevem de maneira muito semelhante a pergunta sobre o "impacto de suas pesquisas":

Acho que a comunidade que faz pesquisa em mutagênese sempre contribuiu bastante, porque eles dão uma resposta muito mais próxima para a população, se comparado a uma genética básica, ao grupo de genética humana, não genética médica. Porque muitas vezes o escopo dos trabalhos é testar drogas, saber se determinado tipo de extrato vegetal é interessante para a população ou não. Algo que utilizamos, e que as empresas farmacêuticas dizem que testaram, a gente vai testar e dizer que não é tão interessante para a população. Tem uma resposta direta (Marina, bióloga, UFPA).

Eu sou biomédico, o meu foco é a saúde humana. O que eu tento responder nas questões de mutagênese são sempre questões de saúde humana. Nesse sentido, a gente tem a questão de que o trabalho que a gente faz pode servir de alerta para desenvolver políticas de utilização de determinadas drogas, determinadas substâncias, que não passaram por um crivo adequado antes de irem para o mercado (Jessé, biólogo, UFPA).

Nesse mesmo sentido, outra pesquisadora de Belém discute a importância da realização de trabalhos de pesquisa com a população do Norte do país.

Por exemplo, nessa área de genética comunitária são inexistentes os trabalhos realizados no Norte, de formação de pessoal, de retorno... Por exemplo, em relação ao número de pacientes atendidos e diagnosticados com doenças genéticas, como isso nunca foi feito, como esses profissionais da atenção primária nunca foram treinados, a gente não sabe qual vai ser $o$ impacto disso nos serviços de genética. Então, medir esse impacto vai ser importante inclusive para o planejamento do SUS. Então fazer esse projeto (...) ajuda na elaboração de políticas públicas, talvez, para a melhoria do serviço (Monique, bióloga, UFPA).

93 Agente mutagênico é todo agente físico, químico ou biológico que, em exposição às células, pode causar mutação, ou seja, um dano na molécula de DNA que não é reparado no momento da replicação celular, e é passado para as gerações seguintes. 
Fica patente, nessas falas, a importância das pesquisas para compreender melhor os problemas de saúde do país - aqui pensando em termos regionais, sobre as regiões Norte e Nordeste - e o "impacto" das pesquisas é concebido nesses moldes, compreender o cenário para ajudar na elaboração de políticas públicas e para melhorar, inclusive, o próprio atendimento em doenças genéticas, o serviço de genética médica da instituição. Descrevendo um projeto mais amplo, em genética médica populacional, outro pesquisador de Belém afirma que o objetivo é duplo, de um lado, a compreensão das especificidades regionais, em termos de doenças genéticas e suas especificidades populacionais, de outro ter um cenário completo, uma "imagem geral” da distribuição das doenças de base genética em nível nacional.

Eu faço parte, por exemplo, de um INCT (...). Qual é a minha parte aqui? É estudar, descrever essas doenças com que a gente vai trabalhar no Brasil aqui na Amazônia. (...) A ideia é que a gente tenha uma visão geral do problema no Brasil, e regionalmente. Porque como é genética populacional, e as populações têm componentes étnicos diferentes, e há variações que estão relacionadas com a etnia, é preciso ter essa visão geral. O (pesquisador de Porto Alegre) tem uma população do Sul e do Sudeste do Brasil, que é predominantemente europeia, eu tenho aqui uma população que é predominantemente indígena, o pessoal do Nordeste tem uma população que é predominantemente africana. Isso dá influências, então eu preciso mapear essas distribuições das doenças de acordo com essas variações étnicas. É preciso ter esses levantamentos locais, mas no fim tem que juntar, se não você não tem a imagem geral. Até para servir como proposta de política de saúde pública (Matheus, médico, UFPA).

Falando mais detalhadamente do que seria uma pesquisa em genética médica populacional, um pesquisador de Porto Alegre diz que o foco é estudar "comunidades que tenham uma concentração de determinadas doenças muito raras", mas que, apesar de raras, apresentam grande quantidade de casos nessas comunidades, "por influência genética”. Ao ser perguntado sobre a importância desse tipo de pesquisa, o entrevistado responde:

Essa sua pergunta é muito boa, porque é uma genética diferente, a gente não faz tanto pesquisa, faz um pouco mais de medicina comunitária. Nós vamos numa localidade que tem um número relativamente grande de casos de uma determinada doença, e a comunidade não sabe muito bem porque aquilo acontece, eles têm as mais variadas teorias sobre aquilo, e nós vamos lá, estudamos, identificamos a causa. Nós temos laboratórios espalhados pelo Brasil que estudam a parte bioquímica, a parte molecular, a parte citogenética, e então nós devolvemos para a comunidade uma resposta: o que está acontecendo e como é que a gente trabalha para prevenir isso, ou para tratar os casos que já existem. É uma ação médica, baseada primeiro numa pesquisa, e a comunidade fica muito satisfeita, porque a gente está devolvendo para eles um resultado prático da pesquisa. Por exemplo, foi identificada uma doença muita rara, chamada (...), no interior da Bahia, tem uma cidadezinha com treze casos de uma doença que no mundo é mais ou menos um caso para cada trezentos mil, e lá eles tem um para cada quatro mil pessoas. Nós identificamos a mutação responsável por isso, e hoje se faz 
um teste de pezinho naquela região, focalizado na doença, porque é uma doença que tem tratamento, então se a gente identificar cedo, o paciente tem uma chance melhor de se desenvolver (Luciano, médico, UFRGS).

Nesse sentido, ainda que seja um trabalho que envolva uma pesquisa - a identificação da mutação responsável pela doença rara naquela região - o acento, no sentido da relevância do trabalho, é dado à assistência, à medicina comunitária, que permite não apenas tratar os pacientes ou realizar aconselhamento genético com as famílias afetadas pela doença, mas "devolver para a comunidade uma resposta", explicar para todos as causas das doenças, as formas de prevenção e tratamento, treinar os profissionais de saúde da região, desenvolver um "teste de pezinho" específico, enfim, uma espécie de conscientização naquela região. Nesse sentido, a importância atribuída ao trabalho está mais na assistência, ligada à elaboração de políticas de saúde específicas, do que na descoberta e publicação de uma determinada mutação de uma doença rara, o que não significa que esse trabalho não tenha sido publicado, apenas que tal publicação não é colocada em primeiro plano no relato.

Há uma dimensão importante nessas citações, que pode ser discutida a partir de duas noções diferentes de um mesmo termo: "impacto". Um pesquisador de Belém, quando perguntado sobre como ele avalia o "impacto" de suas pesquisas, lança mão de duas definições diferentes:

A parte da carcinogênese, com a avaliação dos efeitos no meio ambiente nas populações humanas, tem uma grande inserção (...). São estudos de maior impacto, são mais lidos, há maior interesse. Os estudos pontuais de doenças raras têm um interesse muito focado, para os profissionais da área, né? E tem um terceiro impacto do que a gente atualmente realiza que é o impacto epidemiológico, a partir do diagnóstico onde nunca houve diagnóstico. É o impacto do que a gente faz aqui, que é dar diagnóstico mais preciso de doenças (Augusto, biólogo, UFPA).

De um lado, o pesquisador situa os temas em que conseguiu ter um "impacto" maior, no sentido de conseguir publicar, ser mais lido, despertar o interesse de seus pares no seu trabalho. De outro, refere-se àqueles trabalhos em que "impacto" significa ter uma compreensão maior, do ponto de vista epidemiológico, da distribuição das doenças, notadamente da região Norte, em que antes não havia tanto diagnóstico. Terceiro, tem-se um impacto social, em termos de novos diagnósticos para os pacientes. Essas definições, e a tensão entre elas, aparece na fala de outros pesquisadores:

Não é uma opção de produzir, entre aspas, pesquisa de alto impacto. Ela teria alto impacto quando pudermos implantar isso em larga escala e voltar para política pública mesmo (...) É alguma coisa que está incorporada, onde eu consigo produzir artigos de qualidade em revistas boas, mas não é, e nunca será porque não é o meu foco, produzir, entre aspas, ciência de alto 
impacto, de grandes publicações. A ideia é de realmente poder usar, tudo o que construir, voltar para uma realidade que melhore a atenção à saúde (...). Dentro de genética, você tem aquela genética que é focada em novas descobertas, em proteínas, em ferramentas visando etiologia, ou visando tratamento, que sempre vão ser publicadas em revistas com um perfil de leitor ávido por tecnologia e por novidades. Quando você vai trabalhar com dismorfologia, a gente já sabe que o perfil é outro, é gente que trabalha com clínica, que trabalha com clínica de genética. Clínica de genética é uma população mais restrita, então se você pensar em impacto, considerando o número de leitores, a produção que a gente faz é de altíssimo impacto, mas não é um impacto vinte. Até tenho publicação desse tipo, mas não é aquilo que me interessa mais. Mas as coisas não só são de excelente qualidade como são reprodutíveis em outros países. Então em termos de política pública, em termos de ciência voltada à assistência, não tem dúvida de que tenha alto impacto (Gabriela, médica, Unicamp).

Na discussão acima, as duas dimensões de impacto estão presentes, com uma delas subdividida em duas expressões: de um lado uma ciência de "alto impacto", em termos das publicações especializadas, e que apresenta duas manifestações distintas. Ou seja, ela tanto é definida em termos de número de citações de uma determinada "grande publicação", que desperta o interesse de um conjunto de leitores mais amplo “ávido por tecnologia e por novidades", quanto de uma pesquisa que tem um público mais restrito, interessado em clínica em genética, e cujo objetivo é ter uma "ciência voltada para a assistência", para a incorporação dos achados nas políticas públicas de saúde e para auxiliar o trabalho dos médicos que trabalham com o atendimento. De outro lado, ela identifica o fato de haver o que poderia ser entendido como impacto social: independentemente de repercutir no quesito publicação, acesso ao público especializado, influencia e intervém no âmbito da saúde e, desse ponto de vista, tem um impacto significativo, que pode ou não ter algum tipo de correlação no que concerne às publicações ${ }^{94}$. Nota-se, nesse trecho, uma subversão da pergunta, no momento da entrevista. Quando perguntada sobre o impacto da pesquisa, no sentido de visibilidade e reconhecimento, a resposta dada evidencia uma outra definição do mesmo termo, delineada em termos de impacto social.

É possível identificar, nesse sentido, uma tensão entre fazer ciência de “impacto 20 ” e fazer uma pesquisa que tenha inserção local, que busque tentar resolver os problemas da assistência em genética no Brasil. Tal tensão é explicitada no relato de outra pesquisadora:

Como você avalia, a inserção da pesquisa em genética humana e médicaou só genética médica - no cenário internacional. Como ela é vista?

É, nisso nós vamos perder. Perder que eu quero dizer é que ela é muito modesta (...). Atualmente, para ti fazer pesquisa relevante, tu precisa poder fazer exoma, e uma série de coisas que são muito caras, e em um número

$\overline{94}$ Evidentemente, seria impossível alcançar o impacto social sem que, antes, houvesse o processo de levar a cabo a pesquisa. 
muito grande de pessoas. Nós aqui não conseguimos fazer às vezes nem para os nossos pacientes. Então existe um gap muito grande pelo preço de fazer uma ciência de ponta. Como a gente resolve isso? No meu caso, fazendo coisas relevantes aqui, que tu publica, claro, mas tu vai ver no congresso internacional que o pessoal tem uma tecnologia de análise de doenças genéticas que a gente não consegue bater (Rita, médica, UFRGS).

Existem dois tipos de pesquisadores, eu acho. sendo que uns ficam com um problema e vão até o fundo - e aí eu acho que é questão de personalidade, não é um certo e errado -, e outros são mais abrangentes. Eu sou dessa categoria B. Eu tenho mais de um interesse e mais de uma linha ou atenção. Eu já estou em uma fase que para mim é importante formar pessoas (...) Então o que eu tento fazer é, nos meus orientandos, ver mais ou menos as características deles - dentro das minhas linhas de pesquisa, claro - e ver coisas que eles podem continuar depois (...). Por exemplo, tenho duas alunas de Alagoas, e que vão voltar para lá. Quais os problemas genéticos em Alagoas? Qual o tipo de capacitação elas precisam? Então alguns projetos são mais direcionados com o perfil do meu orientando.

\section{E isso inclusive no sentido regional...}

Isso mesmo! Inclusive com o enfoque nas coisas aqui do Rio Grande do Sul, e do Brasil. Eu tenho uma estratégia mais vinculada, talvez, com a minha formação em medicina. Claro, agora o zika deu um mega impacto, mas teoricamente eu tenho muito menos chance de publicar na Science, porque para isso você tem que estudar uma coisa só, ser o melhor naquilo, ficar só naquilo. E eu morreria de tédio, não quero publicar na Science se esse é o preço. Eu gosto de ter essa visão mais polimórfica (Rita, médica, UFRGS).

A tensão é explicitada nesses dois trechos. Primeiro, colocada em termos de financiamento: não há recursos para fazer uma "ciência de ponta", o que se "resolve" fazendo pesquisas que são relevantes para o contexto local, pesquisas essas que são publicadas, mas que não têm, necessariamente, as tecnologias mais modernas. Segundo, a tensão é colocada em termos de estilo de trabalho: há aqueles que se especializam em um único assunto - e são esses que, segundo a pesquisadora, elevam suas chances de publicar nas melhores revistas, e aqueles que têm mais de uma linha de pesquisa e que, no caso dela, está alinhado com o contexto em que a pesquisa é realizada, como no exemplo dado das alunas de Alagoas ${ }^{95}$.

Mas há também uma tensão relativa a quais devem ser as prioridades do país:

Qual é o momento da genética do Brasil? Da genética clínica, da genética médica. O que a genética pode trazer para o nosso país? Pra que ela serve? É pra viver atrás da última tecnologia? Que custa um absurdo de preço? Não que eu desvalorize, muito pelo contrário, tenho casos, diagnósticos, fantásticos, exoma, array-cgh, genoma, mas são métodos muito caros (...).

95 Falando mais sobre a experiência de Alagoas: "Por exemplo, uma das minhas alunas é de Alagoas. O que a gente fez, no âmbito da genética médica populacional: identificamos uma população, no interior de Alagoas, em que todos têm um defeito de olho que leva a cegueira, é uma falha na formação da íris. O que nós fizemos? Identificamos a mutação, publicamos. Mas e aí, qual a importância para as pessoas lá? Para eles não muda nada. Mas foi feito junto com o grupo de lá, mesmo, então nós voltamos, explicamos para as pessoas porque acontecia isso, é uma doença que a gente chama de autossômica dominante, ou seja, as pessoas que não têm a mutação não têm chance de ter filho afetado e para eles isso não era claro, então já ajuda (Rita, médica, UFRGS)". 
(...). Eu digo que não adianta só você trabalhar dentro de um hospital, de nível terciário: a genética nunca vai cumprir o seu objetivo trabalhando assim (...). Se você quer atingir mesmo a população com o seu conhecimento de genética, você tem que organizar um trabalho municipal. Comecei a fazer esse trabalho, mas não é muito bem-visto.

\section{Mas por quê?}

Porque a instituição quer paper. (...) Só se está preocupada com a última técnica! (...) Isso não é uma crítica, isso está certo. Agora, a genética pode fazer ao país um grande serviço, dando diagnóstico [ênfase] efetivo das deficiências, e prevenindo em nível do município (Tiago, médico, USP/RP).

Aparece, aqui, uma crítica, logo matizada pelo pesquisador, a certas prioridades de pesquisa, ou à prioridade de outros pesquisadores, cujo objetivo é "viver atrás da última tecnologia", que geralmente custa muito caro. Como discutido anteriormente, considerando que tal desenvolvimento tecnológico não é realizado no contexto local, acompanhar os desdobramentos recentes significa a importação de caros equipamentos, de modo a tentar ficar em sintonia com o que é produzido nos centros. Além disso, o pesquisador destaca que as instituições de ensino e pesquisa brasileiras ou, mais especificamente, aquela da qual faz parte, têm como prioridade a pesquisa, a publicação de "papers", e não a assistência, no nível do município, que poderia ser potencializada com o engajamento dos pesquisadores em genética médica. Explicita-se assim a tensão entre a busca da "pesquisa de ponta", que implica estar com as tecnologias sempre atualizadas, o que está acompanhado por alto custo, ou priorizar a resolução dos problemas locais.

A importância de lidar com os problemas locais aparece com muita frequência nas entrevistas, e pode ser sintetizada na fala abaixo:

Eu costumo falar que todos os lugares do mundo têm problemas, só que são problemas diferentes. (...) Cada pessoa voltada para a saúde e para a biologia, daquele local, tem que resolver aquele problema, tu não vai esperar que o cara lá da Indonésia venha resolver a taxa de câncer gástrico aqui do Brasil. Ele pode ajudar, com uma contribuição cientifica que tu venha a usar aqui, claro. Mas quem tem que resolver os problemas daqui? São, naturalmente, as pessoas daqui. Quais os nossos problemas? Por exemplo, o câncer gástrico, a leucemia, que a gente tem problemas, com a população indígena que não responde a certas terapias (...). As questões alimentares daqui: o Pará é conhecido pela culinária, que é diferente. Tem uma série de temperos diferentes, de peixe de tudo quanto é jeito... Tem um monte de coisas que a gente come que a gente não sabe se causa problema ou não, a longo prazo. (...) A gente fez um estudo com a maniçoba, que é uma comida daqui; um outro aluno meu estudou o corante da farinha. Quem está preocupado com o corante da farinha? O cara que não come farinha? Então uma coisa que a gente tenta, isso não é opinião só minha, é voltar os olhos para os problemas daqui (...). Claro, não fica só nisso, genes que são pesquisados em outras regiões do mundo, a gente procura verificar se acontece a mesma coisa aqui. Ou gera informações comuns a todas as pessoas, questões que podem ter reflexo em população europeia, americana, 
asiática... A gente não fica restrito a um bairrismo científico, não é isso, mas a gente tem que ter a consciência de que se alguém tem que fazer alguma coisa aqui, pelos problemas locais, somos nós (Samuel, biólogo, UFPA).

Nessa fala há muita ênfase, com exemplos, na ideia de que os pesquisadores brasileiros são aqueles que devem resolver os problemas de seu contexto, e que não faria sentido esperar que pesquisadores de outros lugares tenham interesse em lidar com essas questões. Ao mesmo, tempo, o pesquisador destaca que isso não significa que só se deva olhar para essas questões, destaca que o que se busca não é um "bairrismo científico", pois enfatiza que são também realizadas pesquisas com genes que estão sendo estudados em outros locais, cujos achados podem ter benefícios para a "população europeia, americana ou asiática".

O foco nos problemas locais é, como mostrado no item anterior, algo muito discutido pelos pesquisadores entrevistados, notadamente nas instituições do Norte e Sul do país visitadas, e um pouco menos evidenciado nas falas dos pesquisadores entrevistados nas instituições do Sudeste, o que pode se relacionar a uma questão de financiamento, como aparece rapidamente na fala de um pesquisador da UFRGS, discutindo possíveis diferenças regionais na maneira de realizar a pesquisa: "claro que os lugares que têm uma oportunidade maior de financiamento buscam ter menos trabalhos desse nível mais artesanal, e mais trabalhos de larga escala". Nesse sentido, a dificuldade financeira em "acompanhar a corrida" pode fortalecer a escolha por "problemas locais", ligando quantidade de recursos à estratégia de pesquisa. Ao mesmo tempo, toda a história, processo de institucionalização e estrutura do campo da genética no país, que busquei mostrar anteriormente, permeados pela defesa da assistência como constitutiva do trabalho dos pesquisadores em genética médica, fornece outros sentidos para essa escolha, para além da limitação de recursos.

A fala de uma pesquisadora de Ribeirão Preto complexifica essa questão:

Falando sobre a sua experiência nos Estados Unidos, você mencionou uma metáfora da "corrida". Você acha que a gente participa da corrida? Difícil, viu. Em algumas áreas acho que a gente tem no Brasil grupos muito fortes que em algumas áreas específicas participam dessa corrida. Mas no geral, não. A gente pode até estar participando da corrida, mas a gente está perdendo, sabe? (...) É interessante você fazer essa pergunta, eu estive em um congresso recentemente, aqui no Brasil, estava participando de uma mesa redonda, que tinha dois pesquisadores, um é brasileiro mas radicado no exterior já há muitos anos, e o outro é um pesquisador que veio de uma instituição europeia. Estávamos nessa mesa redonda, e uma das perguntas feitas pelos ouvintes da plateia foi: "eu consegui avançar até aqui, com sucesso no tratamento com meus pacientes, e eu vejo que lá vocês avançam muito mais, o que mais eu posso fazer? O que falta para a gente fazer e obter o sucesso que vocês têm lá?". E esse pesquisador falou algo um pouco chocante: "vocês estão indo muito bem, mas, assim, façam o que é possível 
ser feito dentro da realidade de vocês, não tentem acompanhar a corrida, porque não vai dar, não vai ser possível" (...). Achei bastante ousado, talvez até um pouco impetuoso, naquele momento, a forma como ele colocou. Porém, quando a gente tira todo o sentimentalismo e você analisa friamente, não é de todo uma mentira. Realmente é muito difícil a gente acompanhar essa corrida, não vou mentir para você.

Esse é um dilema, tentar ou não tentar, gastar esse dinheiro ou desistir... $\mathrm{Na}$ realidade, eu acho que esse dinheiro precisa ser investido, por quê? Porque essa corrida pelo desenvolvimento científico, o investimento de um país no conhecimento científico e tecnológico não vem só para a gente acompanhar a corrida do que está acontecendo nos Estados Unidos e na Europa. Eu acho que o problema é anterior, é preciso entender que o país tem demandas específicas, então o investimento nesse desenvolvimento tecnológico não pode ser só para acompanhar o que os Estados Unidos estão fazendo, porque se você for lá, você vê que eles estão preocupados e estão investindo no que é relevante para o país. Lá nos Estados Unidos tem muitos grupos que estudam câncer de pulmão. Por quê? Porque se você olhar as estatísticas, a quantidade de pessoas que morrem de câncer de pulmão lá é enorme, o gasto que se tem na saúde é enorme, então eles estão investigando aquilo que é relevante para eles. Aqui no nosso país precisa haver um investimento naquilo que é interessante para o desenvolvimento do país, tanto científico quanto tecnológico (Carolina, bióloga, USP/RP).

As perguntas feitas na entrevista buscavam dar conta da percepção da pesquisadora sobre a participação do país na "corrida" - termo usada por ela, e por outros entrevistados para ficar atualizado no desenvolvimento científico e tecnológico, ou, voltando aos termos adotados acima, para realizar "pesquisa de ponta". Em um primeiro momento a pesquisadora afirma que não há técnica que não possa ser feita em alguma instituição no estado de São Paulo, mas que os entraves em matéria de importação de insumos dificultam a realização da pesquisa na rapidez necessária para participar da "corrida". Mais do que isso, há dúvidas evidenciadas pela interação com um pesquisador em um congresso - se vale a pena tentar participar dessa corrida, um pouco nos moldes das falas dos entrevistados discutidas mais acima. Ao mesmo tempo, a tensão entre inserção local e pesquisa de nível internacional é flexibilizada de outra maneira, ao afirmar que os países dos centros estão investindo em seus problemas locais - como aparece no seu exemplo do grande investimento dos Estados Unidos em pesquisas sobre câncer de pulmão. Nesse sentido, a pesquisadora defende que é necessário investir no desenvolvimento tecnológico, não apenas para acompanhar - ou imitar - o que está sendo realizado nos países centrais, mas para ser aplicado aos problemas locais do país ${ }^{96}$.

96 Nessa mesma linha, um pesquisador de Ribeirão afirma que o Brasil tem que investir nas pesquisas que envolvam os problemas de saúde mais frequentes na população, como forma inclusive de economizar os custos com tratamentos: "se você sabe que $30 \%$ da sua população vai desenvolver Alzheimer, por exemplo, ou doenças cardíacas, ou doenças neurológicas, o governo tem condição de fazer um programa dando atenção a isso (...). Isso é a medicina preventiva. O custo disso é muito menor do que fazer uma cirurgia. Ela tem esse potencial. Os grandes centros de pesquisa e hospitais, hoje, têm grupos de genômica, e a gente está fazendo isso. Onde entra a parte de população? Porque a gente pode fazer a epidemiologia genética 
A entrevistada "corrige" a ideia de que nos centros só se realiza pesquisa universal, enquanto os países periféricos estariam preocupados com seus problemas locais, afirmando que os países dos centros também estão fazendo pesquisas relacionadas aos seus problemas de saúde locais, enfatizando a ideia de que a responsabilidade da pesquisa com a saúde pública nacional não estaria presente apenas em contextos periféricos.

Esse trecho da entrevista destacado acima evidencia, também, uma discussão mais complexa: o que define um "problema local" e uma "pesquisa de ponta". Poderíamos formular a questão pensando que, nos centros, os problemas locais se transformam em problemas universais, justamente porque eles têm o monopólio da definição das agendas de pesquisa legítimas, o que deve ser pesquisado, os temas que valem a pena, aqueles que serão mais facilmente aceitos nas publicações. Nesse sentido, uma das dimensões das relações entre centros e periferias é que, nos centros, os problemas locais têm maior possibilidade de se tornarem questões de pesquisa universais, discutidas e publicadas enquanto tal.

Esse monopólio do universal tem consequências para as agendas de pesquisa na periferia, como visto na fala abaixo, discutindo se haveria diferenças regionais - entre os grupos de pesquisa brasileiros - na forma de se fazer pesquisa em genética.

Deveria haver mas acho que não tem. Vou falar do Norte, que conheço mais (...). Eles deveriam ir a fundo na questão das doenças negligenciadas, como malária, dengue, febre amarela, zika. Investigar a susceptibilidade genética a essas infecções, porque sabemos que existe um componente genético importante. Mas eles estão estudando câncer, você entende? Acho que existiria até mais facilidade de financiamento para essas doenças do que para câncer. Mas é aquela coisa: "eu gosto, é mais fácil de publicar".

Eu ia mesmo dizer: o problema das doenças negligenciadas é que como elas são negligenciadas...

Ninguém se interessa. É, mas acho que se a gente não fizer ninguém vai fazer (Débora, bióloga, UFRGS).

Associa-se a escolha do tema "câncer" a uma certa facilidade na publicação dos achados de pesquisa, provavelmente porque a pesquisa em câncer está na ordem do dia, não é uma doença rara ou que atinge apenas países das periferias. Ainda assim, é importante lembrar, como foi visto em outras falas dos pesquisadores oriundos da UFPA, na região Norte, que o tipo de câncer mais estudado por eles é o câncer gástrico e a justificativa é justamente a sua alta incidência local. Logo, mesmo dentro de um tema de pesquisa em consonância com a

disso, a gente pode ver qual é a distribuição dos marcadores na população, para dar suporte para esses censos de doenças, de uma maneira muito mais efetiva, porque a gente conhece qual é a causa da doença (...). A gente tem um projeto na mesa do diretor científico da Fapesp, para estudar a diversidade genética do estado de São Paulo, com pessoas sadias, para a gente ter uma ideia de como essas pessoas daqui dez ou vinte anos estarão, se elas vão desenvolver algum tipo de doença. Todos os países estão fazendo isso, a gente ainda não começou, de uma maneira organizada (Leandro, biólogo, USP/RP)". 
agenda internacional, é possível fazer o recorte - e a justificativa - em termos de um problema local. Uma outra forma de abordar a tensão entre o local e o nacional aparece nesse longo trecho de fala de um pesquisador de Ribeirão Preto:

\section{Há uma certa vantagem em trabalhar com populações brasileiras... \\ Há uma vantagem. \\ Você acha que isso ajuda num reconhecimento, ajuda a abrir mais espaços para a publicação?}

Sim e não. Não, por quê? Porque ninguém está interessado na população brasileira. Não sejamos ingênuos, Como escreveu um editor uma vez quando mandamos um trabalho: "vejo nisso uma importância paroquial". Disse que tem importância para a minha paróquia (...). Agora, a população brasileira, recentemente acabou tendo, assim, um aspecto muito interessante, em um certo sentido, porque a população brasileira é tri-híbrida. O que isso quer dizer? (...) na nossa população você reconhece os três componentes: africano, europeu e indígena. Muito bem. Quando você tem alguma doença, quando você diz "tal gene tem muita frequência nos pacientes assim, assado", você tem que levar em conta essa mistura, porque o gene pode estar relacionado com a ancestralidade, e não com a doença em si. Com isso $a$ população brasileira é um laboratório, então começaram a ter interesse, passou a ter um interesse geral na coisa. (...) Então a publicação de genética humana sobre a população brasileira muitas vezes esbarra no interesse exclusivamente paroquial, e os editores reclamam disso e não publicam. Outras vezes acaba sendo realmente um interesse interessante.

Aqui se coloca que a pesquisa feita com populações brasileiras pode ter um interesse apenas "paroquial", no sentido que dificulta a publicação, porque não interessaria a ninguém fora do contexto local, que não faça parte da população brasileira. Ao mesmo tempo, afirma que a pesquisa pode despertar um interesse maior na comunidade internacional, notadamente nos estudos que envolvem ancestralidade, que apontariam para questões que ultrapassam o contexto local, e que podem ser replicadas em outras pesquisas. Evidencia-se que, em si, estudos tendo como base a população brasileira são questões meramente "locais".

Em algumas entrevistas a tensão explicitada está ausente, ou, em outras palavras, ela não é colocada em termos de uma escolha entre realizar uma pesquisa de "impacto" internacional e contribuir de alguma maneira para os problemas brasileiros.

Que questões, de genética, evolução, a pesquisa com essas populações [indígenas] permitia responder?

Ela contribuiu de maneira importante para mostrar a diferença entre o tipo de construção genética, de estrutura genética dessas populações, quer dizer, populações em nível tribal, com relação às populações urbanas, industriais. (...) Além disso, essas pesquisas contribuíram para a descoberta de uma série de características, fatores médicos, que eram específicas à população, então que não poderiam ter sido investigadas, descobertas, de outra maneira. Então eu acho que houve uma contribuição geral para o estudo da evolução humana, mas também aspectos pontuais, específicos, importantes para a população indígena, sim (...) Um ponto chave é que a gente tinha sempre a 
ideia de que tinha-se uma obrigação de também dar um retorno a essas populações, e isso foi feito principalmente em termos médicos, sempre que possível a gente levava um médico que fornecia medicamentos e atenção médica ao pessoal doente, a questão da vacinação, etc. Então fazia parte da filosofia geral do grupo. A ideia é que nessas relações entre grupos muito diversificados, do ponto de vista biológico e cultural, tem que haver sempre um interesse social. (Joaquim, biólogo, UFRGS).

Aqui há um exemplo de uma pesquisa - bem-sucedida e realizada em colaboração internacional - que pôde conciliar descobertas em uma questão "geral”, o estudo da evolução humana, com alguns benefícios para as populações que foram estudadas para a pesquisa, tanto no sentido de produção de conhecimento sobre "fatores médicos" específicos à população, como no sentido da assistência direta e pontual.

Buscou-se, neste capítulo, avançar na compreensão das relações entre centros e periferias a partir da análise aprofundada dos trabalhos em colaboração internacional, e do delineamento da construção e legitimação de uma agenda de pesquisa periférica. Como visto no capítulo anterior, entende-se que a configuração entre centros e periferias tem consequências práticas em termos do tipo de pesquisa a ser feita e, sobretudo, a ser valorizada. Para tanto, foi realizada a descrição, segundo os geneticistas brasileiros, das razões que levam os pesquisadores dos centros a buscar colaborações com grupos brasileiros na área da genética humana e médica. Partindo dessa discussão, identifica-se a questão do "acesso às amostras" como tema central para as estratégias de colaboração internacional, para a identificação de tensões que atravessam essas colaborações, para a construção de uma agenda de pesquisa com características específicas e, ainda, para a justificativa e legitimação da pesquisa no contexto local.

Em suma, as amostras ocupam papel central na produção do conhecimento em genética humana e médica no contexto dos entrevistados. Primeiramente, elas são elemento importante das colaborações internacionais. No item 3.1.1 descrevi uma série de características que tornam os pesquisadores brasileiros bons colaboradores internacionais: o Brasil é um país grande, com muitos doentes, com uma população que tem variabilidade genética - e amostras de povos indígenas que atraem interesse -, uma infraestrutura de atendimento e pesquisa razoável, concentrada em ilhas de excelência, mas insuficiente. Em segundo lugar, no item 3.2, as amostras reaparecem a partir da discussão sobre o papel esperado dos pesquisadores brasileiros, por parte dos seus pares localizados em países centrais, sobre as tensões envolvidas nessas relações e sobre as possibilidades - e limites - de negociação para colaborações internacionais mais igualitárias. Em seguida, no item 3.3, as 
amostras aparecem como ocupando um espaço importante na constituição de agendas de pesquisa que, como visto, articulam as noções de "oportunidade" (ou "praticidade"), “originalidade" (ou "criatividade") e "não competição direta". Por sua vez, no item 3.4 elas aparecem em termos de justificação científica, no sentido da construção de lacunas nos conhecimentos produzidos pelos centros. $\mathrm{O}$ item 3.5 , por fim, se dedicou a analisar as tensões entre a inserção local das pesquisas e o seu reconhecimento internacional. 


\section{CONSIDERAÇÕES FINAIS}

Nesta tese busquei me apropriar da relação entre centros e periferias como um recurso analítico, de modo a enfatizar a pluralidade e as facetas das relações assimétricas entre os diferentes contextos locais nos quais se desenvolvem as práticas científicas. Tais dimensões da relação entre centro e periferia dizem respeito a aspectos institucionais, como à infraestrutura para a pesquisa e financiamento, mas também a aspectos culturais, além dos propriamente intelectuais. Assim, este trabalho insere-se num esforço contemporâneo de olhar empiricamente para questões abstratas ou programáticas sobre a globalização do conhecimento, na esteira do pensamento pós-colonial e decolonial, associando-as aos estudos de sociologia do conhecimento. Para além da constatação geral ou denúncia de que há uma desigualdade no que tange à produção global de conhecimentos, é preciso delinear os processos, escolhas estratégicas, situações, relacionamentos, e detalhes concretos por meio dos quais essa desigualdade é apropriada, confrontada, produzida e reproduzida por aqueles que participam ativamente do processo de produção do conhecimento.

Argumentou-se neste trabalho que a atividade científica não pode ser tratada de maneira uniforme, havendo configurações distintas de acordo com a área de conhecimento, o espaço disciplinar, a organização institucional, o espaço nacional e a tradição científica à qual se filia. As assimetrias entre centros e periferias remetem à dimensão nacional da ciência que, apesar das tendências de internacionalização ou globalização, continuam a impactar a atividade científica de maneira determinante (Crawford, Shinn \& Sörlin, 1993). Nesse sentido, o ponto de partida desta tese foi a contextualização e análise do campo da genética humana e médica no Brasil, entendido enquanto campo periférico, tal como propôs Medina (2013). Segundo o autor, os campos científicos periféricos são organizados em rede, diferentemente dos campos centrais, que seriam institucionalizados, mais de acordo com o modelo proposto por Bourdieu (1975). Suas principais diferenças são agrupadas em quatro categorias: condições de entrada; número de atores; grau de autonomia e fontes de capital.

Quanto às condições de entrada, os campos em rede seriam mais flexíveis, o que não se confirmou neste estudo de caso. No primeiro capítulo, verificou-se que o campo brasileiro da genética humana e médica tem condições de entrada bem regulamentadas, por mais que a exigência do doutorado seja mais recente e, como visto, alguns pesquisadores da amostra tenham encontrado trabalho antes de obter o título de doutor. Quanto ao número de participantes do campo, embora ele não seja necessariamente pequeno, as disparidades 
regionais e institucionais são notáveis, sendo que algumas instituições, especialmente no Sul e Sudeste, têm uma quantidade de pesquisadores que permite formar grupos de pesquisa com alguma especialização interna, enquanto a maioria das outras instituições conta tão somente com pesquisadores isolados, em departamentos de biologia pouco especializados.

A percepção de uma falta de especialização no campo da genética humana e médica foi tematizada, sob diferentes pontos de vista, nos capítulos 1 e 2 da tese. Para discutir o tema, é preciso observá-lo à luz de três sentidos diferentes, que se complementam mutuamente. No primeiro sentido, a falta de especialização é melhor compreendida se pensada em termos de uma menor profissionalização da pesquisa, quando comparada aos centros. Os pesquisadores descrevem seu ambiente de trabalho como carente no que concerne à infraestrutura. Primeiro, há uma insuficiência de pessoal técnico especializado para manipular - e consertar - os equipamentos. Nesse caso, diferente dos centros, são os estudantes, durante seu processo de formação, que cuidarão dos equipamentos, e ensinarão uns aos outros como manipulá-los. Desse modo, corre-se o risco de que, com a conclusão das pesquisas individuais desses estudantes, um equipamento - muitas vezes caro - se torne ocioso. Segundo, todas as tarefas de gestão e execução da pesquisa estão a cargo dos pesquisadores, desde a compra do material - com todas as dificuldades relativas aos entraves de importação -, passando pelos experimentos, análise, redação dos achados de pesquisa, e, por fim, a prestação de contas às agências de fomento. No contexto de trabalho local, os pesquisadores devem incorporar as funções de secretaria, administração, compras e contabilidade de seu projeto; em contrapartida, os centros são vistos como possuindo uma melhor infraestrutura de apoio e mais possibilidades de se dedicar integralmente à pesquisa, o que também lhes confere condições de competição melhores.

O segundo sentido de uma falta de especialização da área pode ser depreendido da discussão realizada no capítulo 1 , sobre as relações e tensões entre o atendimento clínico e o desenvolvimento de pesquisas. Foi visto que, durante o processo de institucionalização da genética humana e médica, tal articulação - ou indiferenciação - era vista como fundamental para a realização dos trabalhos na área, porque permitia a obtenção de material da pesquisa. Essa baixa diferenciação entre atendimento e pesquisa é, mais contemporaneamente, percebida como tendo consequências negativas. De um lado, esforços de pesquisa são mobilizados para realizar o atendimento, o que pode dificultar a realização de "pesquisas de ponta", de outro, essa situação, vista como não ideal, apresenta consequências para o próprio 
atendimento, uma vez que se mostra, em alguma medida, como ainda pouco profissional, intermitente, e, sobretudo, não inserido como deveria sê-lo no Sistema Único de Saúde.

Por fim, tem-se o terceiro sentido de especialização, em que os pesquisadores percebem seu campo como menos especializado, se comparados aos centros, com suas grandes equipes interdisciplinares, internamente mais alinhadas, com mais pessoas trabalhando em uma mesma pesquisa, com papéis mais bem delimitados - e especializados e que interagem mais entre si. Nesse sentido, os centros estão dotados de laboratórios com maiores equipes, e que trabalham mais proximamente, enquanto o contexto local se apresenta como sendo pouco integrado, com grupos pouco articulados, e com uma densidade menor de interação e discussão. Tal resultado não destoa muito de outros trabalhos realizados em contextos científicos periféricos, em que o isolamento dos pesquisadores é apontado como uma característica marcante (Hwang, 2008; Connell \& Wood, 2002; Thompson, 2006). Em suma, a dimensão relativamente reduzida do campo de pesquisa no país, quando comparada à encontrada nos países centrais, constituiu um obstáculo à organização da pesquisa segundo o que os investigadores designam, por vezes, como modelo de cadeia de causa e consequência, que tiveram ocasião de conhecer em instituições dos centros. Esse modelo caracteriza-se por uma acentuada especialização e por uma divisão do trabalho mais rígida do que a encontrada no contexto local, o que permite aos pesquisadores e técnicos concentrar-se intensivamente em determinadas tarefas ou em orientações específicas de pesquisa.

Outra característica dos campos em rede é a sua baixa autonomia relativa, devido à influência de outros campos, como a economia ou a política, sendo que as universidades são facilmente moldadas por clivagens políticas e o sistema de ciência e tecnologia depende das políticas provisórias que mudam de acordo com o clima político (Medina, 2013). Esses aspectos foram pouco tematizados nesta tese, mas destaca-se aqui a situação pela qual a ciência brasileira está passando - diminuições e intermitência de financiamento, fim do formato estabelecido do Ministério de Ciência e Tecnologia - que afeta significativamente a capacidade desses pesquisadores em se manter - ou tentar se manter - atualizados nas tecnologias que, em áreas de ponta, estão em constante aprimoramento e transformação.

A última característica que distingue os campos, descrita por Medina, diz respeito à fonte de obtenção do capital científico: os campos institucionalizados possuem instituições de consagração internas, enquanto a fonte do capital em campos em redes geralmente vem dos centros, dos campos científicos mais avançados. Ainda que a preferência dos pesquisadores entrevistados seja em publicar em revistas dos centros, reconhecidas como tendo maior 
prestígio, e, sobretudo, conforme visto no segundo capítulo, eles identifiquem a ciência internacional como sinônimo de ciência central - e reconheçam o grande valor da formação e de experiências nesses centros -, não é possível falar em uma completa adesão à ideia de que o reconhecimento advém apenas de fora do contexto nacional. Como visto, em meio ao dilema de competir ou não no cenário internacional, e à descrição de uma série de entraves à participação nessa competição, tem-se uma forte referência, por parte desses pesquisadores, à importância das pesquisas apresentarem "impacto", pensado em termos muito diferentes. Primeiro, se é aos centros que se vai para aprender, não é menos presente a profunda dedicação e esforço para implementar localmente tudo que foi aprendido, de modo a conseguir o que os pesquisadores chamam de independência ou mesmo autonomia. Nesse sentido, há, por parte dos pesquisadores, um enorme empenho em fazer avançar a "ciência brasileira", em um contexto percebido como sendo de adversidade, e o impacto de uma pesquisa é muitas vezes medido em termos de se aquilo foi implementado enquanto competência local. Segundo, se há uma adesão aos padrões dominantes do que é a boa ciência, frequentemente o "impacto" de uma pesquisa é descrito, também, do ponto de vista social, seja no atendimento direto aos pacientes, seja nos benefícios e alcance que as pesquisas podem ter no sentido de uma implementação de políticas públicas na saúde.

Pablo Kreimer (2010), analisando a biologia molecular, e L'Hoste e Hubert (2012), analisando a nanotecnologia, em ambos os casos tendo como foco o contexto argentino, encontraram grupos de pesquisa com perfis distintos, alguns totalmente direcionados à ciência internacional - ou extrovertidos, nos termos de Hountoundji (2006) - e outros comprometidos com a realização de pesquisas cujos interesse e fonte de legitimação são locais. Nesta pesquisa não encontrei separação entre grupos. Os mesmos pesquisadores que realizaram pósdoutorados no exterior, que têm uma longa lista de artigos publicados em periódicos internacionais e que se esforçam para sempre aprender e implementar as técnicas e tecnologias mais recentes - produzidas e legitimadas nos centros -, são aqueles cuja prática cotidiana está, também, referenciada no nacional. Um dos achados desta pesquisa é justamente a complexificação da discussão sobre produção e legitimação do conhecimento, mostrando muito mais mistura do que o cenário delineado por outros pesquisadores. Assim, foram identificadas tanto estratégias de internacionalização da atividade científica como também estratégias de localização - ou relocalização - dessa atividade, articulando a pesquisa realizada nos laboratórios centrais com os contextos locais em que essa investigação adquire uma relevância prática, para além do universo científico. 
Entre estratégias de internacionalização e estratégias de relocalização, as amostras, como procurei mostrar no terceiro capítulo, ocupam um papel fundamental. Viu-se que ter acesso às amostras da população brasileira é o motivo mais recorrente pelo qual pesquisadores brasileiros são procurados por seus pares dos centros, para realizar colaborações internacionais. Foi possível identificar e articular uma série de elementos que tornam os pesquisadores brasileiros colaboradores interessantes, notadamente do ponto de vista das amostras: o país tem uma grande população - em números absolutos e em número de doentes -; uma população diversificada em termos de variabilidade genética; possui centros de pesquisa - "ilhas de excelência" - capazes de coletar e armazenar essas amostras, bem como médicos que são "bons clínicos", e que podem atender adequadamente esses pacientes e produzir os dados necessários para a pesquisa. Trata-se, como visto, de uma configuração paradoxal, em que características pouco vantajosas do ponto de vista do atendimento à saúde - como a quantidade reduzida de hospitais universitários - e da perspectiva da pesquisa (um número reduzido de centros de pesquisa), se tornam vantajosas, do ponto de vista das oportunidades de colaboração internacional. O local acaba por tornar-se valioso para os centros em virtude de sua combinação dinâmica de progresso e atraso, características positivas e negativas que, sem configurar conjuntos fixos de propriedades, variam de sinal conforme as situações específicas.

Ao mesmo tempo, se as amostras são parte importante dessas colaborações, esta tese mostrou que seria simplificador tomá-las como os únicos elementos. Foram justamente descritas e analisadas as diferentes estratégias dos pesquisadores para evitar ficar em uma posição muito assimétrica nas colaborações, participando apenas como fornecedores de amostras, de matéria-prima. Aqui, novamente, destaca-se o forte "nacionalismo" desses pesquisadores, que descrevem as formas de negociar uma participação mais ativa - intelectual - nas colaborações, mesmo quando o papel de fornecedor de dados é o que se espera deles. Nesse sentido, nas colaborações, trata-se de tentar participar ativamente do trabalho, aprender o que for possível e, sobretudo, implantar o que foi aprendido. Diante de diversas dificuldades descritas - o que busquei apresentar como a periferia pensada em termos de falta -, o aprendizado ganha uma dimensão nacionalista, e as colaborações internacionais aparecem como tendo uma dimensão nacional no horizonte, para além, inclusive, de cada uma das carreiras individuais.

Foi analisado, também, um segundo tipo de negociação, em que as amostras se tornam "estratégia" para o estabelecimento de colaborações internacionais. Elas são usadas 
ativamente de forma a iniciar, estabelecer e desenvolver colaborações, ou a viabilizar uma estadia de formação ou pesquisa nos centros. Tal processo foi destacado no capítulo 1 , refletindo sobre o processo de institucionalização da pesquisa em genética, e, para o momento presente, no capítulo 3 desta tese. De um lado, é possível pensar em termos de exploração, de fornecimento de matéria-prima para os centros, tal como descrito por Houtoundji (2006); de outro, essa mesma relação pode ser articulada em termos de estratégias (Medina, 2013; Waast, 2006), de um caminho para trajetórias de colaboração, que é possível negociar, e que alguns indivíduos brasileiros podem, inclusive, obter reconhecimento internacional por seu trabalho, ainda que esse reconhecimento, como visto, tenda a permanecer no nível individual - e não um reconhecimento da genética humana e médica brasileira como um todo.

A atividade de pesquisa que recorre preponderantemente às amostras locais pode ser lida e interpretada em termos de extroversão (Hountondji, 2006; Keim 2011, Bringel \& Domingues, 2015), no sentido de produzir aquilo que os pares internacionais estão pedindo, os dados que não podem ser obtidos nos espaços centrais. Mas, igualmente, pode ser vista na chave da produção de conhecimento com impacto local efetivo - não entendido simplesmente em termos de retórica de legitimação de uma agenda de pesquisa, já que muitos dos entrevistados de fato aplicam os conhecimentos produzidos, participando direta ou indiretamente do atendimento aos pacientes e da formulação de políticas para incluir a genética na saúde pública.

As amostras são, também, uma dimensão importante da construção das agendas de pesquisa locais. Analisou-se a busca por questões que podem ser respondidas com os recursos disponíveis no contexto local, e, principalmente, que são favorecidas por esse mesmo contexto, no sentido de "oportunidades" que seriam mais limitadas para os pesquisadores dos centros. As escolhas de temas de pesquisa, nesse sentido, foram entendidas como uma busca de formas de inserção e diferenciação em um ambiente científico internacional marcado pela competição entre agentes com recursos desiguais. Ao mesmo tempo, conforme discutido no terceiro capítulo, devido às relações assimétricas entre centros e periferias, essa participação não significou passar a fazer parte dos centros, ou, em outros termos, romper com uma divisão internacional do trabalho científico estruturada em centros e periferias. Se, de um lado, há uma definição da agenda de pesquisa feita a partir do contexto local, de modo a alcançar certa diferenciação em relação aos centros e, portanto, não concorrer diretamente com temas de pesquisa considerados já monopolizados, em que os centros possuem vantagens; de outro essa participação é percebida como marginal, de abrangência ou impacto 
limitados ao próprio contexto local, com poucas possibilidades de adquirir dimensão - e reconhecimento - internacional.

As amostras são, também, parte da estratégia de legitimação da agenda de pesquisa elaborada no contexto local. Tal justificativa foi mobilizada, pelos entrevistados, a partir da ideia de que os achados de pesquisa produzidos pelos centros nem sempre se confirmam, ao analisar as amostras de pacientes de outros contextos - "o que funciona para uma determinada população pode não funcionar para outra", o que torna pesquisas "locais" relevantes, seja ao preencher uma lacuna nos conhecimentos produzidos, seja em tratamentos da população local, que nem sempre responde bem ao "protocolo padrão mundial". No terceiro capítulo discuti brevemente como essa agenda de pesquisa está em consonância com tendências internacionais de um redirecionamento contemporâneo dos estudos genéticos em que, cada vez mais, a variação genética entre as populações humanas se torna objeto de interesse, sendo construída enquanto necessidade, em termos de política pública, para mitigar as disparidades de saúde entre populações e para o desenvolvimento de uma medicina personalizada.

Se o primeiro objetivo posto por esta tese foi averiguar a existência, características e dimensões de uma divisão internacional do trabalho científico, na genética humana e médica, estruturada em centros e periferias, ao final deste trabalho a resposta mais precisa a essa pergunta seria: sim e não. Como visto no interlúdio e, de forma mais complexa, no terceiro capítulo, esse elemento está presente no cotidiano, nas práticas de pesquisa e nas colaborações ensejadas pelos pesquisadores. Mas estão igualmente presentes contestações a esse modelo de integração subordinada (Kreimer, 2006) e o fortalecimento do contexto local. Como visto na Introdução, Alatas (2003) distingue três níveis do que seria uma divisão global do trabalho nas ciências sociais: 1) a divisão entre trabalho intelectual teórico e empírico; 2) a divisão entre trabalhos realizados em outros países e trabalhos realizados no próprio país; 3) a divisão entre estudos comparativos e estudos de caso isolados. O primeiro nível, para analisar a genética humana e médica, foi substituído pela divisão entre trabalho de análise e trabalho de produção de dados que, tal qual discutido no interlúdio, foi encontrado em $25 \%$ dos artigos em coautoria internacional analisados. O segundo nível foi considerado pouco pertinente para os trabalhos na área, porque os capítulos 2 e 3 indicaram que o mais comum, no tempo presente, não é ir a um determinado local coletar dados - embora isso esteja presente no processo de institucionalização da área no país, tal como visto no primeiro capítulo -, mas fazer colaborações para a obtenção desses dados. A divisão entre estudos comparativos e estudos de caso isolados - ressignificada para estudos que incluem amostras de diversas populações e 
estudos com amostras apenas locais - também foi identificada e trabalhada, sobretudo no Interlúdio e no capítulo 3. Ao mesmo tempo, como dito, foram encontradas configurações que não se encaixavam nessas categorias, sendo o principal exemplo a noção de que os centros recebem os pesquisadores periféricos para serem mão de obra barata. Nesses casos, muitas vezes os pesquisadores brasileiros conseguem se integrar aos grupos, participar das análises e mesmo ser primeiros autores de artigos importantes - porém, como destacado, trabalhando de graça para os centros.

Retoma-se, ainda, o modelo da distinção centro-periferia de Wiebke Keim (2010), que propõe diversos pares conceituais, visando diferenciar as assimetrias no que tange às condições materiais (par subdesenvolvimento-desenvolvimento); as assimetrias no desenvolvimento de teorias, métodos e técnicas (par dependência-autonomia); e as imagens ou reconhecimento simbólico - que as diferentes contribuições têm no cenário internacional da ciência (par marginalidade-centralidade). No que diz respeito à genética humana e médica, nos capítulos primeiro e segundo foram descritas a infraestrutura, a organização interna e o acesso aos recursos financeiros. O mais importante para esta pesquisa, no entanto, são as duas outras dimensões do modelo.

A segunda dimensão delineada por Keim (2010) caracteriza as condições de existência e reprodução das temáticas científicas, em que a periferia é notadamente caracterizada por sua dependência vis-à-vis as agendas de pesquisa definidas de maneira exógena pelo centro. É possível afirmar, por sua vez, que quanto ao prestígio das teorias e métodos advindos dos centros, da autoridade reconhecida a esses pesquisadores, bem como do valor superior atribuído às publicações em revistas internacionais indexadas, esta pesquisa encontrou uma grande adesão aos padrões e valores provenientes dos centros, seja na observação do processo de institucionalização da pesquisa em genética e a correspondente influência histórica da Fundação Rockefeller, seja no tempo presente. Para os meus entrevistados, centros são os espaços aos quais se vai para aprender as técnicas e metodologias necessárias à pesquisa, em que o ambiente de pesquisa é efervescente, integrado, veloz, dinâmico; em suma, é nos centros que são desenvolvidos os conhecimentos, as metodologias e as ferramentas de ponta. Nesse sentido, os pesquisadores no contexto local são fortemente dependentes dos conhecimentos e metodologias oriundos dos centros. Os periódicos centrais são, também, a escolha por excelência para dar vazão aos resultados de pesquisa, ainda que, como visto no segundo capítulo, esse processo de publicação esteja permeado de dificuldades e essa adesão seja feita com críticas, sobretudo à pressão para publicar em quantidade nesses periódicos, à 
prioridade que as instituições de ensino e pesquisa e agências de financiamento dão à pesquisa em face da assistência, e, ainda, àquilo que os pesquisadores formularam em termos de "modas científicas" - é necessário sempre correr atrás da última técnica, caso se queira publicar nessas revistas, o que não significa, necessariamente, a construção de conhecimentos mais robustos e, sobretudo, a melhora do atendimento aos pacientes.

No que diz respeito à agenda de pesquisa, uma relação de dependência é menos clara. Ao contrário do que propõem alguns dos autores mobilizados na Introdução (Hountondji, 1990; Gaillard, 1994; Alatas, 2003), não é possível afirmar que há uma conformação a uma agenda científica formulada nos centros, com a adoção dos mesmos objetos e temas de pesquisa pelos pesquisadores entrevistados. O objetivo dos pesquisadores entrevistados não é simplesmente a reprodução padronizada de agendas de pesquisa globais relacionadas à genética humana e médica. Alinhar as agendas de pesquisa brasileiras às prioridades internacionais é um componente importante da área, particularmente porque as questões da diferença populacional estão cada vez mais informando a pesquisa em genômica aplicada à saúde. No entanto, as prioridades por eles estabelecidas decorrem, em grande medida, de seu ambiente imediato, sendo influenciadas pela frequência de doentes em determinada região, bem como por "amostras de conveniência", coletadas de populações indígenas próximas, ou já estocadas em freezers dos laboratórios. A pesquisa em genética humana e médica é, assim, calibrada localmente.

Ao mesmo tempo, como visto, é difícil formular a constituição da agenda de pesquisa em termos de autonomia, visto que são agendas ligadas ao local, mas concebidas, também, enquanto estratégias de participação - marginais - no cenário internacional. A terceira dimensão proposta por Keim (2010) trata justamente da posição e do reconhecimento internacional da produção científica, sendo que o par marginalidade-centralidade descreve a função que uma comunidade científica desempenha na produção global de conhecimentos, já brevemente problematizado acima, ao discutir as amostras.

Como exposto no segundo capítulo, mesmo os que os pesquisadores se considerem privilegiados no contexto nacional, os laboratórios visitados nos centros são sempre percebidos como tendo mais recursos, seja em termos de financiamento ou de infraestrutura de pesquisa. Os centros são vistos como espaços em que a pesquisa se desenvolve de maneira veloz, em que os materiais necessários para o trabalho são obtidos com agilidade e, por isso, é possível participar da "corrida" por descobertas. Além disso, os centros são descritos como tendo um aproveitamento mais racional de sua infraestrutura, em contraste com o contexto 
local, ou seja, mesmo quando a periferia possui mais equipamentos, tal característica deixa de ser considerada positiva, sendo a ênfase posta na falta de racionalidade. A partir das diferentes comparações mobilizadas pelos pesquisadores entrevistados, foi possível elencar algumas dimensões das relações entre centros e periferias. A primeira dimensão reside no reconhecimento de que os centros são locais em que se vai para aprender, locais que ensinam, pois é em seus laboratórios que foram desenvolvidos os principais instrumentos, técnicas e tecnologias de pesquisa. O espaço nacional é visto, assim, como a arena para a recepção da ciência feita em outro lugar, no "cenário internacional", entendido, com frequência, como sinônimo de central. A segunda dimensão identificada nesta pesquisa é a articulação que imputa aos centros uma velocidade e uma efervescência ausentes no contexto periférico, descrito em termos de morosidade e isolamento. A terceira dimensão das relações entre centros e periferias incide mais diretamente sobre o tema da infraestrutura de pesquisa e, principalmente, do seu financiamento, em que os primeiros são vistos como tendo uma maior disponibilidade de recursos para a pesquisa, enquanto o contexto local é percebido como de escassez, ainda que pensada em termos relativos, se comparado a outros laboratórios brasileiros. A quarta dimensão identificada opõe o prestígio e reconhecimento dos centros a uma periferia carente de credibilidade científica, chegando mesmo a ser objeto de preconceito em relação a sua capacidade de contribuir para o estoque de conhecimento na área.

Essas e outras tantas oposições foram mobilizadas pelos pesquisadores entrevistados, ao serem solicitados a comparar suas experiências de trabalho no Brasil com suas experiências de formação e trabalho nos centros. Tais comparações, sempre tão duras e pouco mediadas, em que raramente se elenca características positivas para descrever o contexto brasileiro, me levou a formular a noção de periferia pensada em termos de falta, para sintetizar a percepção e a construção do contexto periférico. Foi em virtude do extenso trabalho de campo realizado que pude expressar desse modo as diferentes assimetrias que colocam os pesquisadores em posições periféricas. Pode-se mobilizar essa noção no estudo de outras disciplinas e contextos periféricos, entendida não em uma dimensão quantitativa - o quanto falta -, mas, sobretudo, como dimensão qualitativa, buscando retraçar o que falta aos diferentes contextos, auxiliando a montar um cenário mais complexo e preciso das relações entre centros e periferias na produção, circulação e legitimação do conhecimento científico.

Ao mesmo tempo, a noção de periferia pensada em termos de falta, mais do que um retrato fiel e objetivo das condições e desigualdades da produção do conhecimento em contextos periféricos, pode ser conjugada à discussão de processos de centralização e 
periferização, tal como proposto por Neves (2014; 2017). O autor, como exposto na Introdução, afirma que a distinção centro-periferia é recorrentemente utilizada por pesquisadores brasileiros como critério de observação, que organiza seus contextos, expectativas e práticas, sendo os processos de "periferização" aqueles em que se atribui um valor negativo ao que se faz e como se faz, o que conduz a expectativas de nãoreconhecimento, não publicação, e de circulação restrita dos conhecimentos produzidos (Neves, 2014; 2017). Assim, é possível pensar a formulação em questão como um outro elemento de um processo de periferização.

Como discutido na Introdução, a constatação das assimetrias na produção do conhecimento não pode velar a inegável heterogeneidade entre os países tidos como periféricos, de um lado, e centrais, de outro, o que me fez recorrer ao uso dos termos no plural, referindo-me a "centros" e "periferias". Este estudo de caso priorizou a observação e entrevistas com pesquisadores em centros de excelência e, mesmo nesse conjunto, foi possível perceber heterogeneidade e mesmo hierarquias. Recorrendo novamente à noção de periferia pensada em termos de falta, é notável como articulações discursivas muito semelhantes foram usadas por pesquisadores situados na UFPA para falar de suas experiências formativas e de trabalho em instituições do Sul e Sudeste, seja em termos de recursos financeiros, infraestrutura de pesquisa, profisssionalização, quantidade de pesquisadores, especialização, velocidade, ou possibilidade de participar da competição internacional. Além disso, no segundo capítulo descrevi o processo de ir-aprender-voltar-implementar como o mais comum em termos de estadia nos centros, e essa mesma modalidade foi encontrada entre aqueles pesquisadores de Belém que realizaram seus doutorados ou pós-doutorados em instituições brasileiras mais centrais, como a USP/RP e a UFRGS. Revelou-se, assim, que esses pesquisadores atuam em um espaço claramente percebido em suas hierarquias internas, que eles analisam criticamente e, simultaneamente, reproduzem em suas práticas cotidianas de dedicação à carreira científica.

Os centros de excelência visitados para a realização desta pesquisa desempenharam, por vezes, papel central para pesquisadores localizados em outras instituições brasileiras e, também, em países da América Latina. Reflexão semelhante pode ser feita, ainda que em menor medida, considerando os diferentes países que compõem o "centro", a partir, por exemplo, da caracterização de uma das entrevistadas que distingue entre o congresso da Sociedade Americana de Genética Humana, enquanto espaço em que se pode de fato aprender o que há de mais desenvolvido na área, e o congresso da Sociedade Europeia, para o qual se 
vai para fazer turismo, evidenciando estratificações percebidas no interior do espaço constituído pelos países considerados centrais para o desenvolvimento da pesquisa na área. Essa dimensão é fundamental para a compreensão dos diferentes níveis das relações entre centros e periferias na produção, circulação e legitimação do conhecimento, compreensão que por certo necessita de maior aprofundamento e complexificação em pesquisas futuras.

Entendo que foi possível fundamentar de que modo as percepções semelhantes das relações entre centro e periferia são encontradas não somente em um mesmo país, o Brasil, mas em um conjunto restrito de centros de excelência. Os achados apresentados e interpretados nesta tese fortalecem, portanto, a abordagem proposta, de que centros e periferias devem ser tomadas como categoriais relacionais, e não cartográficas, cujo conteúdo empírico e analítico apenas se revela à medida que a investigação se aprofunda em áreas disciplinares e contextos locais e institucionais específicos. 


\section{REFERÊNCIAS BIBLIOGRÁFICAS}

ABIR-AM, Pnina. The discourse of physical power and biological knowledge in the 1930s: a reappraisal of the Rockefeller Foundation's 'policy' in Molecular Biology. Social Studies of Science, v. 12, n. 3, pp. 341-382, 1982.

ADAMS, Mark B. (Org.). The wellborn science: eugenics in Germany, France, Brazil and Russia. Oxford: Oxford University Press, 1990.

AKIWOWO, Akinsola. Universalism and indigenisation in sociological theory: introduction. International sociology, v. 3, n. 2, pp. 155-160, 1988.

ALATAS, Syed Farid. Academic Dependency and the global division of labour in the Social Sciences. Current Sociology, v. 51, n. 6, pp. 599-613, 2003.

ALMEIDA, Ana Maria Fonseca de; MOSCHKOVICH, Marilia \& POLAZ, Karen. Pesquisando os grupos dominantes: notas de pesquisa sobre acesso às informações. Revista Pós Ciências Sociais, v. 9, n. 17, pp. 161-174, 2012.

ALTBACH, Philip G. An international academic crisis? The American professoriate in comparative perspective. Daedalus, v. 126, n. 4, p. 315-338, 1997.

International Higher Education: Reflections on Policy and Practice. Chestnut Hill, $\overline{\mathrm{MA}}$ : Center for International Higher Education, Boston College, 2006.

ALVES, Alexandre Donizeti; YANASSE, Horacio Hideki \& SOMA, Nei Yoshihiro. "Perfil dos bolsistas produtividade das áreas de engenharia de produção e de transportes do CNPq: enfoque na subárea de pesquisa operacional”. In: Anais do XLIII Simpósio Brasileiro de Pesquisa Operacional. Ubatuba/São Paulo, vol. 8, 2011. pp. 144-155.

ANDERSON, Warwick \& ADAMS, Vincanne. "Pramoedya's chicken: Postcolonial Studies of Technoscience". In: HACKETT, Edward J.; AMSTERDAMSKA, Olga; LYNCH, Michael E. \& WAJCMAN, Judy. (Orgs.). The New Handbook of Science and Technology Studies. Cambridge, MA: MIT Press, 2008. pp. 181-204.

ARAÚJO, Aldo M. A influência de Theodosius Dobzhansky no desenvolvimento da genética no Brasil. Episteme, v. 7, n. 3, pp. 43-54, 1998.

Spreading the evolutionary synthesis: Theodosius Dobzhansky and Genetics in Brazil. Genetics and Molecular Biology, v. 7, n. 2, pp. 467-475, 2004.

" "Síntese evolutiva, constrição, ou redução de teorias: há espaço para outros enfoques?". In: PRESTES, M. E. B.; MARTINS, L. P. \& STEFANO, W. (Orgs.). Filosofia e História da Biologia 1. São Paulo: Fundo Mackenzie de Pesquisa, 2006. pp. 21-39.

ARVANITIS, Rigas. La division internationale du travail scientifique. Dossier édité par Terry Shinn, Dominique Vellard et Roland Waast, Cahiers de la recherche sur l'éducation et les savoirs. Revue d'anthropologie des connaissances, v. 5, n. 3, pp. 635-637, 2011 a. 
. Que des réseaux! Compte rendu de Caroline Wagner. The New Invisible College. Science for Development. Revue d'anthropologie des connaissances, v. 5, n. 1, pp. 178-185, $2011 b$.

BABER, Zaheer. Provincial universalism. The landscape of knowledge production in an era of globalization. Current Sociology, v. 51, n. 6, pp. 615-623, 2003.

BASALLA, George. The spread of western science. Science, v. 156, n. 3775, 1967, pp. 611622.

BEATTY, John. "Origins of the U. S. Human Genome Project: the changing relationships between genetics and national security". In: SLOAN, Phillip R. (Org.). Controlling our destinies: historical, philosophical, ethical, and theological perspectives on the Human Genome Project. Indiana: University of Notre Dame Press, 2000, p. 131-54.

BEIGEL, Fernanda. "Introduction". In: America. Londres: Ashgate, 2013. pp. 1-28. The politics of academic autonomy in Latin

BEIGUELMAN, Bernardo. A genética humana no Brasil. Ciência e Cultura. v. 31, n. 10, pp. 1198-1217, 1979.

. "A genética humana no Brasil”. In: FERRI, Mário Guimarães \& MOTOYAMA, Shozo. (Org.). História das ciências no Brasil. São Paulo: Edusp, 1979-1980. pp. 274-305.

BEN-DAVID, Joseph. O papel do cientista na sociedade. São Paulo: Pioneira, 1974.

BETRÁN, Ana Pilar; YE, Jianfeng; MOLLER, Anne-Beth; ZHANG, Jun; GÜLMEZOGLU, A. Metin \& TORLONI, Maria Regina. The Increasing Trend in Caesarean Section Rates: Global, Regional and National Estimates: 1990-2014. PLOS One. v. 11, n. 2, 2016.

BIAGIOLI, Mario. "Rights of Rewards? Changing Frameworks of Scientific Authorship". In: \& GALISON, P. (Org.). Scientific Authorship: credit and intellectual property in science. New York: Routledge, 2013. pp. 253-279.

. \& GALISON, Peter (Org.). Scientific Authorship: credit and intellectual property in science. New York: Routledge, 2013.

.$\&$ "Introduction". In: \& (Org.). Scientific Authorship: credit and intellectual property in science. New York: Routledge, 2013. pp. 1-9.

BICUDO, Edison. Genomics politics through space and time: the case of bioinformatics in Brazil. Public Health Genomics. v. 19, n.2, pp. 81-92, 2016.

BOURDIEU, Pierre. La spécificité du champ scientifique et les conditions sociales du prógrés de la raison. Sociologie et Societé, v. 7, n. 1, pp. 91-118, 1975.

. Homo academicus. Paris: Éditions de Minuit, 1984.

. Science de la science et réflexivité. Paris: Raisons d'Agir, 2001. 
. Os usos sociais da ciência. São Paulo: Editora UNESP, 2003.

BRAND, Amy; ALLEN, Liz; ALTMAN, Micah; HLAVA, Marjorie \& SCOTT, Jo. Beyond authorship: attribution, contribution, collaboration, and credit. Learned Publishing, v. 28, n. 2, pp. 151-155, 2015.

BRIEGER, Friedrich Gustav. Friedrich Gustav Brieger (depoimento, 1977). Mimeo. Rio de Janeiro, CPDOC, 2010, 98p.

BRINGEL, Breno. Desafios para os periódicos de Ciências Sociais no Brasil: cenários, atores e políticas. Revista Pensata, v. 4, n. 2, pp. 53-64, 2015.

. \& DOMINGUES, José Maurício. Teoria social, extroversão e autonomia: impasses e horizontes da sociologia (semi)periférica contemporânea. Cadernos CRH, v. 28, n. 73, pp. 59$76,2015$.

BRITO DA CUNHA, Antônio. Perspectivas atuais e futuras das ciências biológicas no Brasil. Brasília: CNPq, 1990.

BRUNONI, Décio. Aconselhamento Genético. Ciência \& Saúde Coletiva, v. 7, n. 1, pp. 101107, 2002.

BURCHARD, Esteban Gomzález. The Importance of Race and Ethnic Background in Biomedical Research and Clinical Practice. New England Journal of Medicine, v. 348, pp. 1170-1175, 2003.

CALLON, Michel. "Some elements of a sociology of translation: Domestication of the scallops and fishmen of St. Brieuc Bay". In: LAH, John (Ed.). Power, action and belief: a new sociology of knowledge. London: Routledge and Kegan Paul, 1986. pp. 196-233.

CAPES. A internacionalização na Universidade Brasileira: Resultados do Questionário Aplicado pela CAPES. $2017<$ https://www.capes.gov.br/images/stories/download/diversos/Ainternacionalizacao-nas-IES-brasileiras.pdf $>$. Mimeo. 51 p. Acesso em: $01^{\circ}$ de maio de 2018.

CAPLAN, Arthur. L. "What's morally wrong with eugenics?”. In: SLOAN, Phillip R. (Org.). Controlling our destinies: historical, philosophical, ethical, and theological perspectives on the Human Genome Project. Indiana: University of Notre Dame Press, 2000. pp. 209-222.

CARDOSO, Fernando Henrique \& FALETTO, Enzo. Dependência e desenvolvimento na América Latina: ensaio de interpretação sociológica. Rio de Janeiro: Zahar Editores, 1970.

CARLOTTO, Maria Caramez. Veredas da mudança na ciência brasileira: discurso, institucionalização e práticas no cenário contemporâneo. São Paulo: Editora 34/Associação Filosófica Scientiae Studia, 2013.

. Universitas semper reformanda?: a história da Universidade de São Paulo e o discurso da gestão à luz da estrutura social. Tese (Doutorado em Sociologia). Faculdade de Filosofia, Letras e Ciências Humanas, Universidade de São Paulo, São Paulo, 2014. 
CHAKRABARTY, Dipesh. Provincializing Europe: postcolonial thought and historical difference. New Jersey: Princeton University Press, 2000.

CNPq. Chamada CNPq $N^{o}$ 12/2017 - Bolsas de Produtividade em Pesquisa. 2017.

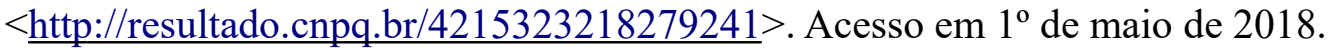

COLLINS, Harry M. The Seven Sexes: A Study in the Sociology of a Phenomenon, or the Replication of Experiments in Physics. Sociology, v. 19, n. 2, pp. 205-224, 1975.

CONNELL, Raewyn W. Southern Theory. Cambridge: Polity Press, 2007.

. \& WOOD, Julian. Globalization and scientific labour: patterns in a life-history study of intellectual workers in the periphery. Journal of Sociology, v. 38, n. 2, pp. 167-90, 2002.

. et al. Toward a global sociology of knowledge: post-colonial realities and intellectual practices. International Sociology, v. 32, n. 1, pp. 21-37, 2017.

CORDEIRO, Antonio R. \& SALZANO, Francisco M. "Secção de Genética do Instituto de Ciências Naturais da Universidade do Rio Grande do Sul". In: BRITO DA CUNHA, Antônio; FROTA-PESSOA, Oswaldo \& BLUMENSCHEIN, Almiro. Atas do primeiro simpósio sulamericano de genética. São Paulo: Faculdade de Filosofia, Ciências e Letras da Universidade de São Paulo, 1961. pp. 227-248.

CORDEIRO, Antonio. R. Antonio Cordeiro (depoimento, 1977). Mimeo. Rio de Janeiro: CPDOC, 2010, 87p.

CORREA, Marilena V. O admirável Projeto Genoma Humano. Physis. Revista de Saúde Coletiva, v. 12, n. 2, pp. 277-299, 2002.

CRAWFORD, Elizabeth; SHINN, Terry \& SÖRLIN, Sverker. "The Nationalization and Denationalization of the Sciences: An Introductory Essay". In: ; $\quad$ \&

(Eds.). Denationalizing Science: The Contexts of International Scientific Practice. Dordrecht: Springer, 1993. pp. 1-42.

CUETO, Marcos. Missionaries of science: the Rockefeller Foundation and Latin America. Bloomington: Indiana University Press, 1994.

CUKIERMAN, Henrique. Yes, nós temos Pasteur: Manguinhos, Oswaldo Cruz e a história da ciência no Brasil. Rio de Janeiro: Relume Dumará/Faperj, 2007.

DAL POZ, Maria Estér Soares. Da dupla à tripla hélice: o projeto Genoma Xylella. Dissertação (Mestrado em Política Científica e Tecnológica). Instituto de Geociências, Universidade Estadual de Campinas, Campinas, 2002.

DANTES, Maria Amélia. Fases da implantação da ciência no Brasil. Quipu, México, v. 5, n. 2, pp. 265-75, 1988.

DE SOLLA PRICE, Derek J. Little Science, Big Science. New York: Columbia University Press, 1963. 
DEBERT, Guita Grin. "Problemas relativos à utilização da história de vida e história oral". In: CARDOSO, Ruth. A aventura antropológica: teoria e pesquisa. Rio de Janeiro: Paz e Terra, 1986. pp. 141-156.

DESLAURIERS, Jean-Pierre e KÉRISIT, Michèle. "O delineamento de pesquisa qualitativa". In: POUPART, Jean et al. A pesquisa qualitativa. Enfoques epistemológicos e metodológicos. Petrópolis: Vozes, 2008. pp. 127-153.

DREGER, Alice Domurat. "Metaphors of morality in the Human Genome Project". In: SLOAN, Phillip R. (Org.). Controlling our destinies: historical, philosophical, ethical, and theological perspectives on the Human Genome Project. Indiana: University of Notre Dame Press, 2000. p. 155-184.

DUTRA, Rogéria Campos de Almeida \& AZEVEDO, Leonardo Francisco. Programa "Ciência sem Fronteiras": geopolítica do conhecimento e o projeto de desenvolvimento brasileiro. Ciências Sociais Unisinos, v. 52, n. 2, pp. 234-243, 2016.

ELZINGA, Aant. The new production of particularism in models relating to research policy. A critique of Mode 2 and Triple Helix. Paper prepared for the Nobel Symposium Science and Industry in the 20 Century. Stockholm, 2002.

EMERICK, Maria Celeste; MONTENEGRO, Karla Bernardo Mattoso \& DEGRAVE, Wim. Novas tecnologias na genética humana: avanços e impactos para a saúde. Rio de Janeiro: GESTEC-NIT/Fiocruz, 2007.

ESTUDOS AVANÇADOS. Faculdade de Filosofia da USP: lições inesquecíveis (entrevista). Estudos Avançados. São Paulo, v. 7, n. 18, pp. 189-207, 1993.

ETZKOWITZ, Henry \& LEYDESDORFF, Loet. The Dynamics of Innovation: From National Systems and 'Mode 2' to a Triple Helix of University-Industry-Government Relations. Research Policy, v. 29, n. 2, pp. 109-123, 2000.

FAUNDES, Aníbal \& CECATTI, José Guilherme. A operação cesárea no Brasil: incidência, tendências, causas, consequências e propostas de ação. Cadernos de Saúde Pública, v. 7, n. 2, pp. 150-173, 1991.

FERRARI, Nadir. Conversando com Eliane Azevedo. Episteme. v. 18, pp. 7-17, 2004.

"Newton Freire-Maia e a genética humana no Brasil". In: MARTINS, Lilian Al-Chueyr Pereira; REGNER, Anna Carolina K. P. \& LORENZANO, Pablo (Orgs.). Ciências da vida: estudos filosóficos e históricos. Campinas: Associação de Filosofia e História da Ciência do Cone Sul (AFHIC), 2006. pp. 309-332.

FERREIRA, Mariana Toledo. A institucionalização da pesquisa em genética no Brasil e seus pesquisadores: um estudo de caso do Centro de Estudos do Genoma Humano da USP. Dissertação (Mestrado em Sociologia). Faculdade de Filosofia, Letras e Ciências Humanas, Universidade de São Paulo, São Paulo, 2013. 
. Trajetórias e divisão do trabalho no laboratório de genética humana. Scientiae Studia. v. 13, n. 4, pp. 899-927, 2015.

FORMIGA, Dayana Oliveira. A escola de genética Dreyfus-Dobzhansky: a institucionalização da genética na Faculdade de Filosofia, Ciências e Letras da Universidade de São Paulo (19341956). Dissertação (Mestrado em História Social). Faculdade de Filosofia, Letras e Ciências Humanas, Universidade de São Paulo, São Paulo, 2007.

FREEMAN, Christopher. The 'National System of Innovation' in historical perspective. Cambridge Journal of Economics. v. 19, 1995, pp. 5-24.

FREIRE-MAIA, Newton. Agradecimentos. Ciência e Cultura. v. 41, n. 5, 1989, pp. 461-465.

FROTA-PESSOA, Oswaldo. O passado que se faz presente. Ciência e Cultura, v. 41, n. 5, pp. 456-61, maio 1989.

FURTADO, Caio Alves; DAVIS JR., Clodoveu A.; GONÇALVES, Marcos André \& ALMEIDA, Jussara Marques de. A spatiotemporal analysis of Brazilian science from the perspective of researchers' career trajectories. PLOS One, v. 10, n. 10, 2015.

GAILLARD, Jacques. "La naissance difficile des communautés scientifiques". In: SALOMON, Jean-Jacques; SAGASTI, Francisco \& SACHS-JEANTET, Celine (Orgs.). La quête incertaine: science, technologie et développement. New York, Paris: Economica, 1994. pp. 213-49.

. "Vers une interdépendance interactive". In: (Ed). Coopérations scientifiques internacionales. Les sciences hors d'Occident au XX siècle, volume 7. Paris: Orstom Éditions, 1996. pp. 7-21.

.Measuring research and development in developing countries: main characteristics and implications for the Frascati Manual. Science, Technology \& Society. v. 15, n. 1, pp. 77-111, 2010 .

GARCIA, Sylvia Garcia \& CARLOTTO, Maria Caramez. "Institutional specificity and organizational change: A case of university social engagement in Brazil". In: PINHEIRO, Romulo; BENNEWORTH, Paul \& JONES, Glen A. (Eds.). Universities and regional development: a critical assessment of tensions and contradictions. Nova Iorque: Routledge, Taylor and Francis, 2012. pp. 124-140.

GAUDILLIÈRE, Jean-Paul. Molecular Biology in the French tradition? Redefining local traditions and disciplinary patterns. Journal of the History of Biology, v. 26, n. 3, pp. 473-498, 1993.

GIBBON, Sahra. Ancestry, temporality, and potentiality: Engaging cancer genetics in southern Brazil. Current Anthropology. v. 54 (Suppl. 7), pp. S107-S117, 2013.

"Anticipating Prevention; constituting clinical need, rights and resources in Brazilian Cancer Genetics". In: BURKE, Nancy J.; KAMPRIANI Eirini \& MATHEWS, Holly F. 
(Eds.). Anthropologies of Cancer in Transnational Worlds. Londres e Nova Iorque: Routledge, 2015. pp. 68-86.

. Translating Population Difference: The Use and Re-Use of Genetic Ancestry in Brazilian Cancer Genetics. Medical Anthropology, v. 35, n. 1, pp. 58-72, 2016.

GIBBONS, Michael et al. The new production of knowledge: the dynamics of science and research in contemporary societies. Londres: Sage, 1994.

GINGRAS, Yves. Physics and the rise of scientific research in Canada. Montreal: McGillQueen's University Press, 1991.

. Les formes spécifiques de l'internationalité du champ scientifique. Actes de la Recherche en Sciences Sociales, v. 1-2, n. 141-142, pp. 31-45, 2002.

GLICK, Thomas. "A Fundação Rockefeller e a emergência da genética no Brasil (19431960)". In: DOMINGUES, Heloisa Maria Bertol; SÁ, Magali Romero \& recepção do darwinismo no Brasil. Rio de Janeiro: Editora Fiocruz, 2003. pp. 145-163.

- O programa brasileiro de genética evolucionária de populações, de Theodosius Dobzhansky. Revista Brasileira de História, v. 28, n. 56, pp. 315-325, 2008.

GOODSON, Ivor F. Developing Narrative Theory. Life Histories and Personal Representation, Londres: Routledge, 2013.

GUEDES, Moema de Castro; AZEVEDO, Nara \& FERREIRA, Luiz Otávio. A produtividade científica tem sexo? Um estudo sobre bolsistas de produtividade do CNPq. Cadernos Pagu, Campinas, n. 45, pp. 367-399, 2015.

GUIMARÃES, Reinaldo. A diáspora: um estudo exploratório sobre o deslocamento geográfico de pesquisadores brasileiros na década de 90. Dados. Rio de Janeiro, v. 45, n. 4, pp. 705-750, 2002.

HABIB, Paula Arantes Botelho Briglia. Agricultura e biologia na Escola Superior de Agricultura Luiz de Queiroz (ESALQ): os estudos de genética nas trajetórias de Carlos Teixeira Mendes, Octavio Domingues e Salvador de Toledo Piza Jr. (1917-1937). Tese (Doutorado em História das Ciências e da Saúde). Fundação Oswaldo Cruz, 2010.

HAMBURGUER, Amelia Imperio. Fapesp 40 anos: abrindo fronteiras. São Paulo: EDUSP, 2004.

HEDGECOE, Adam M. \& MARTIN, Paul A. "Genomics, STS, and the making of sociotechnical futures". In: HACKETT, Edward J.; AMSTERDAMSKA, Olga; LYNCH, Michael E. \& WAJCMAN, Judy. (Eds.). The New Handbook of Science and Technology Studies. Cambridge, MA: MIT Press, 2008. pp. 817-840.

HENRIQUES, Frederico de Oliveira. Idéias, redes e dinâmica política: a construção da agenda da inovação na FAPESP. Dissertação (Mestrado em Sociologia). Faculdade de Filosofia, Letras e Ciências Humanas, Universidade de São Paulo, São Paulo, 2010. 
HERRERA, Amílcar. Ciencia y Política en América Latina. México: Siglo Veintiuno, 1971.

HILGARTNER, Stephen. "Making maps and making social order: governing American Genomics Centers, 1988-1993”. In: GAUDILLIÈRE, Jean-Paul \& RHEINBERGER, HansJörg. (Orgs.). From molecular genetics to genomics: the mapping cultures of TwentiethCentury genetics. Londres: Routledge, 2004. pp. 113-127.

HINE, Christine. Information technology as an instrument of genetics. Genetic Engineer and Biotechnologist. v. 15, n. 2-3, pp. 113-124, 1995.

HOGLE, Linda F. "Emerging medical technology". In: HACKETT, Edward J.; AMSTERDAMSKA, Olga; LYNCH, Michael E. \& WAJCMAN, Judy. (Eds.). The New Handbook of Science and Technology Studies. Cambridge, MA: MIT Press, 2008. pp. 841874.

HOUNTONDJI, Paulin J. Scientific dependence in Africa today. Research in African Literatures, v. 21, n. 3, pp. 5-15, 1990.

"Global knowledge: imbalances and current tasks". In: NEAVE, Guy. Knowledge, power and dissent: critical perspectives on Higher Education and Research in Knowledge Society. Paris: UNESCO Publishing, 2006. pp. 41-60.

HUBERT, Matthieu \& L'HOSTE, A. Spivak. Integrarse en redes de cooperación en nanociencias y nanotecnologías: el rol de los dispositivos instrumentales. REDES, v. 15, n. 29, pp. 69-91, 2009.

HWANG, Kumju. "International Collaboration in Multilayered Center-Periphery in the Globalization of Science and Technology”. Science, Technology, \& Human Values, v. 33, n. 1, pp. 101-133, 2008.

JABBEHDARI, Sahra \& WALSH, John P. Authorship Norms and Project Structures in Science. Science, Technology, \& Human Values, v. 42, n. 5, pp. 872-900, 2017.

JORDAN, Kathleen \& LYNCH, Michael. The dissemination, standardization and routinization of a molecular biological technique. Social Studies of Science. v. 28, n. 5-6, pp. 773-800, 1998,

KARADY, Victor. La migration internationale d'étudiants en Europe, 1890-1940. Actes de la recherche en sciences sociales. v. 145, n. 5, pp. 47-60, 2002.

KAY, Lily E. The molecular vision of life: Caltech, the Rockefeller Foundation and the new Biology. Nova Iorque/Oxford: Oxford University Press, 1993.

KEIM, Wiebke. Aspects problématiques des relations internationales en sciences sociales: pour un modèle centre-périphérie. Revue d'Anthropologie des Connaissances. v. 4, n. 3, pp. 570-598, 2010.

Counter hegemonic currents and internationalization of sociology. Theoretical reflections and one empirical example. International Sociology. v. 26, n. 1, pp. 123-145, 2011. 
KEVLES, Daniel J. In the name of eugenics: genetics and the uses of human heredity. Berkeley: University of California Press, 1985.

KIMURA, Edna T. \& BAÍA, Gilson S. Rede ONSA e o Projeto Genoma Humano do Câncer: Contribuição ao Genoma Humano. Arquivos Brasileiros de Endocrinologia Metabólica. v. 46, n. 4, pp. 325-329, 2002.

KNIGHT, Jane. Updated internationalization definition. International Higher Education. n. 33, pp. 2-3, 2003.

Sense, 2008.

Higher education in turmoil: the changing world of internationalization. Rotterdam:

KOENIG, Barbara A.; LEE, Sandra Soo-Jin \& RICHARDSON, Sarah S. "Introduction: Race and genetics in a genomic age". In: ______. e ___. (Orgs.). Revisiting race in a genomic age. Nova Brunswick: Rutgers University Press, 2008. pp. 1-20.

KOHLER, Robert E. The experience of Warren Weaver and the Rockefeller Foundation programme in molecular biology. Minerva. v. 14, n. 3, 1976, pp. 279-306.

Lord of the fly: drosophila genetics and the experimental life. Chicago: University of Chicago Press, 1994.

KREIMER, Pablo. De Probetas, Computadoras y Ratones: La Construcción de una Mirada Sociológica sobre la Ciencia. Bernal: Universidad Nacional de Quilmes, 2005.

- Dependientes o integrados? La ciencia latinoamericana y la nueva división internacional del trabajo científico. Nómadas, n. 24, pp. 199-212, 2006.

Ciencia y periferia: nacimiento, muerte y resurrección de la biología molecular en la Argentina. Buenos Aires: Eudeba, 2010.

- "Contra viento y marea en la ciencia periférica: niveles de análisis, conceptos y métodos. In: . (Org.). Contra viento y marea: emergencia y desarrollo de campos científicos en la periferia: Argentina, segunda mitad del siglo XX. Buenos Aires: CLACSO, 2016.

L'HOSTE, Ana Spivak \& HUBERT, Matthieu. Mobilité scientifique et réflexivité des chercheurs. Comment les déplacements façonnent des modes de production de connaissances. Revue d'anthropologie des connaissances, v. 6, n.2, pp. 357-380, 2012.

LANDER, Edgardo (Org.). A colonialidade do saber: eurocentrismo e ciências sociais. Perspectivas latino-americanas. Buenos Aires: CLACSO, 2005.

LATOUR, Bruno. Ciência em ação: como seguir cientistas e engenheiros sociedade afora. São Paulo: UNESP, 2000.

. \& WOOLGAR, Steve. A vida de laboratório: a produção dos fatos científicos. Rio de Janeiro: Relume Dumará, 1997. 
LAVIÈRE, Vincent et al. Contributorship and division of labor in knowledge production. Social Studies of Science. v. 46, n. 3, pp. 417-435, 2016.

LAW, John. On sociology and STS. The Sociologial Review. v. 56, n. 4, pp. 623-649, 2008.

LEITE, Marcelo. Promessa do genoma. São Paulo: Editora UNESP, 2006.

LEMAINE, Gérard. Science normale et science hypernormale. Les stratégies de différenciation et les stratégies conservatrices dans la science. Revue Française de Sociologie, v. 21, n. 4 , pp. 499-527, 1980.

LENOIR, Timothy. "A disciplina da natureza e a natureza das disciplinas". In:

Instituindo a ciência: a produção cultural das disciplinas científicas. São Leopoldo: Editora Unisinos, 2003. pp. 63-98.

LINDEE, Susan. James Van Gundia Neel (1915-2000). American Anthropologist. v. 103, pp. 502-505, 2001. 2005.

Moments of true in genetic medicine. Baltimore: The Johns Hopkins University Press,

LOCK, Margaret. "Biomedical technologies, cultural horizons and contested boundaries". In: HACKETT, Edward J.; AMSTERDAMSKA, Olga; LYNCH, Michael E. \& WAJCMAN, Judy. (Eds.). The New Handbook of Science and Technology Studies. Cambridge, MA: MIT Press, 2008. pp. 875-900.

LOSEGO, Philippe \& ARVANITIS. La science dans les pays non hégémoniques. Revue d'anthropologie des connaissances, v. 2, n. 3, pp. 334-342, 2008.

MACAULEY, Domhnall. Cite the Workers. British Medical Journal. v. 305, p. 120, 1992.

MACKENZIE, Adrian. Bringing sequences to life: how bioinformatics corporealizes sequences data, New Genetics and Society. v. 22, n. 3, pp. 315-332, 2003.

MARCOVICH, Ann \& SHINN, Terry. Regimes of science production and diffusion: towards a transverse organization of knowledge. Scientiae Studia. v. 10, Special Issue, p. 33-64, 2012.

MARINHO, Maria Gabriela S. M. C. Norte-americanos no Brasil: uma história da Fundação Rockefeller na Universidade de São Paulo (1934-1952). Campinas/Bragança Paulista: Autores Associados/EDUSF/Fapesp, 2001.

. Elites em negociação: breve história dos acordos entre a Fundação Rockefeller e a Faculdade de Medicina de São Paulo (1916-1931). Bragança Paulista: EDUSF, 2003.

MARTINS, Carlos Benedito. A reforma universitária de 1968 e a abertura para o ensino superior privado no Brasil. Educação e Sociedade, v. 30, n. 106, pp. 15-35, 2009.

MAYR, Ernest. The growth of biological thought: diversity, evolution, and inheritance. Cambridge, Massachusetts: Harvard University Press, 1982. 
MEDINA, Eden; MARQUES, Ivan da Costa \& HOLMES, Christina. (Orgs.). Beyond Imported Magic: Essays on Science, Technology, and Society in Latin America. Cambridge, Massachusetts: The MIT Press, 2014.

MEDINA, Leandro Rodriguez. Centers and peripheries in knowledge production. Nova Iorque: Routledge, 2013.

. The circulation of european knowledge: Niklas Luhmann in the hispanic Americas. Nova Iorque: Palgrave Macmillan, 2014.

MENDES, Erasmo Garcia. Instituto de Biociências. Estudos Avançados. v. 8, n. 22, pp. 541543, 1994.

MENEGHINI, Rogério \& PACKER, Abel L. Articles with authors affiliated to Brazilian institutions published from 1994 to 2003 with 100 or more citations: II - identification of thematic nuclei of excellence in Brazilian science. Anais da Academia Brasileira de Ciências. v. 78, n. 4, pp. 841-853, 2006.

.; MUGNAINI, Rogério \& PACKER, Abel L. International versus national oriented Brazilian scientific journals: a scientometric analysis based on SciELO and JCR-ISI databases. Scientometrics, Amsterdam. v. 69, n. 3, pp. 529-538, 2006.

MERTON, Robert King. Science, technology \& society in seventeenth century England. Nova Iorque: Harper \& Row, 1970.

."The Reward System of Science". In: . The Sociology of Science: theoretical and empirical investigations. Chicago: Chicago University Press, 1973. pp. 280-412.

The sociology of science: theoretical and empirical investigation. Chicago: University of Chigago Press, 1973.

- Ensaios de sociologia da ciência. São Paulo: Associação Filosófica Scientiae $\overline{\text { Studia/Editora 34, } 2013 .}$

MERZ, Martina \& SORMANI, Philippe. "Configuring new research fields: how policy, place, and organization are made to matter". In: $\&$ . (Orgs.). The Local Configuration of New Research Fields: on regional and national diversity. Cham/Heidelberg/Nova Iorque/Dordrecht/Londres: Springer, 2016. pp. 1-34.

MEYER, Jean-Baptiste; KAPLAN, David \& CHARUM, Jorge. Scientific nomadism and the new geopolitics of knowledge. International Social Science Journal. v. 53, n. 168, pp. 309$321,2001$.

MIGNOLO, Walter D. Local histories/global designs: coloniality, subaltern knowledges and border thinking. Princeton: Princeton University Press, 2000.

MONTE SIÃO, João Franco. As contribuições de Theodosius Dobzhansky para o desenvolvimento da genética no Brasil (1943-1960): um estudo bibliométrico. Filosofia e História da Biologia, v. 2, pp. 203-225, 2007. 
MOULIN, Anne-Marie. "Biomedicine et santé". In: KLEICHE-DRAY, Mina \& WAAST, Roland (Org.). Le maroc scientifique. Paris: Editions Publisud, 2008. pp. 223-234.

NEGRAES, Carmen Lucia B. \& EGLER, Paulo C. G. The Brazilian Genome Project: A successful example of a research network. Science, Technology and Society, v. 7, n. 2, pp. 313-338, 2002.

NELSON, Richard R. National innovation systems: a comparative analysis. Oxford: Oxford University Press, 1993.

NEVES, Fabrício Monteiro. A contextualização da verdade ou como a ciência torna-se periférica. Civitas, v. 14, n. 3, pp. 556-574, 2014.

Alguns elementos do regime de administração da irrelevância. Anais do $18^{\circ}$ Congresso

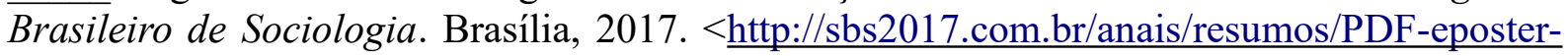
trab-aceito-1153-2.pdf>. Acesso em $1^{\circ}$ de maio de 2018.

NUNES, João Arriscado \& GONÇALVES, Maria Eduarda (Orgs.). Enteados de Galileu? A semiperiferia no sistema mundial da ciência. Porto: Edições Afrontamento, 2001.

OLIVEIRA, Miguel Ernesto Gabriel Couceiro de. A institucionalização do primeiro Centro de Pesquisa de Genética do Rio de Janeiro (1943-1968): o campo da genética e seus atores sociais. Tese (Doutorado em História das Ciências e da Saúde). Casa Oswaldo Cruz/Fiocruz, 2015.

OLDHAM, Geoffrey. "La coopération scientifique internationale". In: WAAST, Roland. Les sciences hors d'Occident au XXe siècle. Volume 1: Les Conférences. Paris: Orstom, 1995. pp. 87-98.

PAULA, Maria de Fátima Costa de. USP e UFRJ: a influência das concepções alemã e francesa em suas fundações. Tempo social, v. 14, n. 2, pp.147-161, 2002.

PAVAN, Crodowaldo. Algumas questões sobre o desenvolvimento da ciência no Brasil e as lições na área da genética. Ciência e Cultura, v. 41, n. 5, pp. 452-455, 1989.

. Crodowaldo Pavan (depoimento, 1977). Mimeo. Rio de Janeiro, CPDOC, 2010, 152p.

PIZZIRANI-KLEIRER, Aline Aparecida \& AZEVEDO, João Lúcio de. Histórico inicial da genética de microrganismos no Brasil e as reuniões científicas. Disponível em: $<\underline{\text { http://www.sbg.org.br/Downloads/Memoria/SBG_HIST REUN_GEN MICRORG }}$

\%28Pizzirani-Kleiner,\%20AA\%29.pdf>. Acesso em: 15/07/2013.

POLANYI, Michael. The republic of science and its political and economic theory. Minerva, v. 1, pp. 54-73, 1962.

PREBISCH, Raúl. O desenvolvimento econômico da América Latina e seus principais problemas. Revista Brasileira de Economia. FGV, v. 3, n.3, pp. 47-111, 1949. 
QUIJANO, Aníbal. Coloniality of Power and Eurocentrism in Latin America. International Sociology, v. 15, n. 2, pp. 215-232, 2000.

RABINOW, Paul. Making PCR: a story of biotechnology. Chicago: University of Chicago Press, 1996.

RAMOS, Milena Yumi. Formação de doutores no país e no exterior: impactos na internacionalização da ciência brasileira. Tese (Doutorado em Política Científica e Tecnológica). Instituto de Geociências, Universidade Estadual de Campinas, 2014.

Internacionalização da pós-graduação no Brasil: lógica e mecanismos. Educação e Pesquisa, v. 44, pp. 1-22, 2018.

. \& VELHO, Lea. Formação de doutores no Brasil e no exterior: impactos na propensão a migrar. Educação e Sociedade, v. 32, n. 117, pp. 933-951, 2011.

RAPINI, Márcia Siqueira. Interação universidade-empresa no Brasil: evidências do Diretório dos Grupos de Pesquisa do CNPq. Estudos Econômicos, v. 37, n. 1, pp. 211-233, 2007.

RAPP, Rayna. Testing Women, Testing the Fetus: The Social Impact of Amniocentesis in America. Nova Iorque: Routledge, 1999.

RENNIE, Drummond; YANK, Veronica \& EMANUEL, Linda. When authorship fails: a proposal to make contributors accountable. Journal of the American Medical Association, v. 278, n. 7, pp. 579-585, 1997.

; FLANAGIN, Annette \& YANK, Veronica. The contributions of authors. Journal of the American Medical Association, v. 284, n. 1, pp. 89-91, 2000.

RHEINBERGER, Hans-Jörg. "Beyond nature and culture: modes of reasoning in the age of molecular biology and medicine". In: LOCK, Margaret; YOUNG, Allan \& CAMBROSIO, Alberto. (Orgs.). Living and working with the new medical technologies. Cambridge: Cambridge University Press, 2000. pp. 19-30.

SAID, Edward W. Orientalism. New York: Pantheon Books, 1978.

SALZANO, Francisco Mauro. "History and development of human genetics in Brazil". In: DRONAMRAJU, Krishna R. (Org.). The history and development of human genetic: progress in different countries. Washington: World Scientific, pp. 228-241, 1991.

- James V. Neel and Latin America - or how scientific collaboration should be conducted. Genetics and Molecular Biology, v. 23, n. 3, pp. 557-561, 2000.

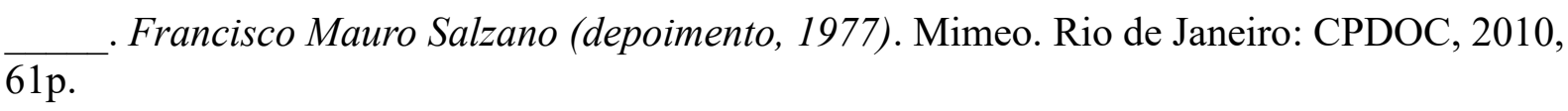

(Org.). Recordar é viver: a história da Sociedade Brasileira de Genética. Ribeirão Preto: Sociedade Brasileira de Genética, 2011. 
SAMPAIO, Helena. O setor privado de ensino superior no Brasil: continuidades e transformações. Revista Ensino Superior Unicamp, pp. 28-43, 2011.

SANTOS, Boaventura de Sousa. "Para além do pensamento abissal: das linhas globais a uma ecologia de saberes". In:

Paulo: Cortez, 2010. pp. 31-83. \& MENESES, Maria Paula. Epistemologias do Sul. São

SANTOS, Ricardo Ventura. Guardian angel on a nation's path: contexts and trajectories of physical anthropology in Brazil in the late nineteenth and early twentieth centuries. Current Anthropology. v. 53, pp. 17-32, 2012.

.; LINDEE, Susan e SOUZA, Vanderlei Sebastião de. Varieties of the Primitive: Human Biological Diversity Studies in Cold War Brazil (1962-1970). American Anthropologist. v. 116, n. 4, pp. 723-735, 2014.

SCHWARTZMAN, Simon. Formação da comunidade cientifica no Brasil. São Paulo/Rio de Janeiro: Editora Nacional/Financiadora de Estudos e Projetos, 1979.

SCHOTT, Thomas. Ties between center and periphery in the scientific world-system: accumulation of rewards, dominance and self-reliance in the center. Journal of World-Systems Research. v. 4, n.2, pp. 112-144, 1998.

SEBASTIÁN, Jesús. Dimensiones y métrica de la internacionalización de las universidades. Universidades. UDUAL: México, n. 51, pp. 3-16, out./dez. 2011. Disponível em:

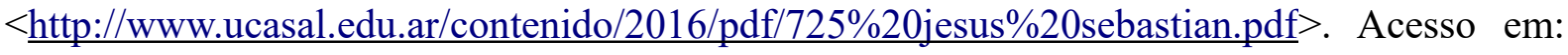
10 jan. 2018.

SHEFFER, Mário et al. Demografia médica no Brasil 2018. São Paulo: FMUSP, Conselho Regional de Medicina do Estado de São Paulo e Conselho Federal de Medicina, 2018.

SHINN, Terry. Division du savoir et spécificité organisationnelle. Les laboratoires de recherche industrielle en France. Revue française de sociologie. v. 21, n. 1, pp. 3-35, 1980.

- Regimes de produção e difusão de ciência: rumo a uma organização transversal do conhecimento. Scientiae Studia, v. 6, n. 1, pp. 11-42, 2008.

\& RAGOUET, Pascal. Controvérsias sobre a ciência: por uma sociologia transversalista da atividade científica. São Paulo: Associação Filosófica Scientiae Studia/Editora 34, 2008.

. \& MARCOVICH, Ann. Padrões sociointelectuais da pesquisa em nanoescala: laureados com o Prêmio Feynman de Nanotecnologia, 1993-2007. Scientia Studiae. v. 7, n. 1, pp. 11-39, 2009.

SINGER, Paul. De dependência em dependência: consentida, tolerada e desejada. Estudos Avançados, v. 12, n. 33, pp. 119-130, 1998.

STEPAN, Nancy Leys. "A hora da eugenia”: raça, gênero e nação na América Latina. Rio de Janeiro: Editora Fiocruz, 2005. 
SILVA, Renan Gonçalves Leonel da. A agenda de pesquisa em oncologia molecular no estado de São Paulo (1971-2013). Tese (Doutorado em Política Científica e Tecnológica). Instituto de Geociências, Universidade Estadual de Campinas, 2015.

\& COSTA, Maria Conceição da. Instrumentos de política de ciência e tecnologia em genômica do Estado de São Paulo. Revista de Políticas Públicas, v. 16, n. 2, pp. 493-501, 2012.

SLOAN, Phillip R. "Completing the tree of Descartes". In: (Org.). Controlling our destinies: historical, philosophical, ethical, and theological perspectives on the Human Genome Project. Indiana: University of Notre Dame Press, 2000. pp. 1-26.

SOUZA, Vanderlei Sebastião de \& SANTOS, Ricardo Ventura. The emergence of human population genetics and narratives about the formation of the Brazilian nation (1950-1960). Studies in History and Philosophy of Biological and Biomedical Sciences. v. 47, pp. 97-107, 2014.

STRAUSS, Anselm \& CORBIN, Juliet. Pesquisa qualitativa: técnicas e procedimentos para o desenvolvimento de teoria fundamentada. Porto Alegre: Artmed, 2008.

SUÁREZ-DIAZ, Edna \& BARAHONA, Ana. "Postwar and Post-Revolution: Medical Genetics and Social Anthropology in Mexico (1945-1970)". In: GAUSEMEIER, Bernd, MÜLLER-WILLE, Staffan \& RAMSDEN, Edmund. (Eds.). Human Heredity in the Twentieth Century. Londres: Pickering \& Chatto, 2013. pp. 101-112.

THOMPSON, Eric C. Internet-Mediated Networking and Academic Dependency in Indonesia, Malaysia, Singapore and the United States. Current Sociology, v. 54, n. 1, pp. 41$61,2006$.

TOMITA, Noemy Y. De História Natural a Ciências Biológicas. Ciência e Cultura. v. 47, n. 12, pp. 1173-1177, 1990.

TRAWEEK, Sharon. "Big science and colonialist discourse: building high-energy physics in Japan". In: GALISON, Peter \& HEVLY, Bruce. Big science: the growth of large-scale research. Stanford: Stanford University Press, 1992. pp. 100-128.

TRINDADE, Hélgio. "Institucionalização e internacionalização das ciências sociais na América Latina em questão". In: ALMEIDA, Ana Maria Fonseca de et al. Circulação internacional e formação intelectual das elites brasileiras. Campinas: Unicamp, 2004. pp. $107-143$

UNESCO. UNESCO Science Report 2010: The Current Status of Science Around the World, Paris: United Nations Educational, Scientific and Cultural Organization, 2010.

VARSAVSKY, Oscar. Por uma Política Científica Nacional. Rio de Janeiro: Paz e Terra, 1976.

VELHO, Léa. Formação de doutores no país e no exterior: estratégias alternativas ou complementares? Dados. Rio de Janeiro, v. 44, n. 3, pp. 607-631, 2001. 
VELLOSO, Jacques. "Pós-Graduação: egressos, trabalho e formação no país e no exterior". In: STEINER, João Evangelista \& MALNIC, Gerhard. (Orgs.). Ensino superior: conceito e dinâmica. São Paulo: EDUSP, 2006. pp. 177-212.

VESSURI, Hebe; GUÉDON, Jean-Claude \& CETTO, Ana M. Excellence or quality? Impact of the current competition regime on science and scientific publishing in Latin America and its implications for development. Current Sociology. v. 62, n. 5, pp. 647-665, 2014.

WAAST, Roland. Science in Africa: from institutionalization to scientific free markets. Science, Technology \& Society, v. 8, n. 2, pp. 153-81, 2003.

WAGER, Elizabeth. Do medical journals provide clear and consistent guidelines on authorship? Medscape General Medicine, v. 9, n. 3, p. 16, 2007.

WAGNER, Caroline. "International Collaboration in Science and Technology: Promises and Pitfalls". In: BOX, Louk \& ENGELHARD, Rutger (Orgs.). Science and Technology Policy for Development: Dialogues at the Interface. Londres: Anthem Press, 2006. pp. 165-176.

WAINER, Jacques \& VIEIRA, Paula Avaliação de bolsas de produtividade em pesquisa do CNPq e medidas bibliométricas: correlações para todas as grandes áreas. Perspectivas em Ciência da Informação. v. 18, n. 2, pp. 60-78, 2013.

WILKIE, Tom. Projeto Genoma Humano: um conhecimento perigoso. Rio de Janeiro: Jorge Zahar, 1994.

ZIMAN, John. "What is happening to science?". In: COZZENS, Susan et al. (Orgs.). The research system in transition. Dordrecht: Kluwer Academic, 1990. pp. 23-33.

ZUCKERMAN, Harriet A. Patterns of name ordering among authors of scientific papers: a study of social symbolism and its ambiguity. American Journal of Sociology, v. 74, n. 3, pp. 276-291, 1969.

. Scientific elites. Nobel laureates in the United States. Nova Jersey: Transaction Publishers, 1977. 


\section{ANEXOS}

Anexo 1 - Roteiro base para entrevistas

1. Quando começa o seu interesse pela genética humana? Qual foi seu primeiro contato?

\section{Formação (doutorado):}

a) Como foi que você se decidiu pelo seu tema de pesquisa?

b) Que metodologias eram necessárias para realizar sua pesquisa? Como aprendeu? As técnicas estavam estabelecidas no laboratório?

c) Que instrumentos eram necessários? Eles estavam disponíveis na sua universidade?

d) Que tipo de literatura mais usou? Quais eram as suas principais fontes?

e) Fazer o doutorado no Brasil foi uma escolha? Você cogitou fazer doutorado no exterior?

3. Formação no exterior (mestrado, doutorado, doutorado-sanduíche ou pós-doutorado):

a) Qual era a motivação para estudar no exterior?

b) Como se deu a escolha da instituição? Como foi o processo?

c) Quais as atividades exercidas? Você poderia me escrever um pouco seu dia a dia de trabalho?

d) Você tinha um(a) orientador(a)? Como era a relação com o(a) orientador(a) e as/os colegas?

e) Estava inserido em alguma pesquisa coletiva ou realizava o trabalho individualmente?

f) Como eram as instalações nos países de destino? Teve acesso a novos materiais e instrumentos?

g) $\mathrm{O}$ estilo de pesquisa era muito diferente daquele no qual você fazia pesquisa anteriormente?

h) Você identifica padrões de treinamento diferentes no Brasil e no país em que você foi fazer essa etapa da sua formação?

i) Os temas pesquisados na Universidade de destino eram muito diferentes dos pesquisados no Brasil? Ou tratados de maneira diferente? 
j) Foi importante para sua formação enquanto pesquisador? Por que?

k) Você conheceu pessoas importantes para a sua trajetória futura? Manteve os contatos depois do retorno? A experiência incentivou co-autorias internacionais?

1) Você cogitou ficar?

\section{Trabalho atual}

a) Para a sua pesquisa atual, quais são os recursos necessários? (instrumentos, periódicos, bancos de dados etc.). Eles são recursos locais ou estrangeiros? De fácil acesso?

b) Como é seu dia a dia de trabalho?

c) Você considera que faz pesquisa básica ou aplicada ou acha que essas são mas definições para pensar a pesquisa que realiza?

d) Faz aconselhamento genético ou atendimento de pacientes? Ele é importante para a sua pesquisa?

\section{Colaborações científicas}

a) Quais são as suas principais colaborações?

b) Você pode dar um exemplo de colaboração significativa, no país ou no exterior (com pesquisadores de fora da sua universidade) que você considere bem-sucedida. Como ela se iniciou? Quais foram as principais motivações? Os principais resultados? E as dificuldades?

c) Perguntar, a partir de artigo em coautoria internacional selecionado pelo Lattes, como foi o processo de escrita, a negociação da autoria, a divisão do trabalho: como surgiu a ideia do artigo? Como vocês se "conheceram"? Como foi a divisão do trabalho? Qual foi sua participação nesse artigo?

d) Por que fazer colaborações em genética humana e médica?

e) O que é uma boa colaboração? O que é uma má colaboração?

f) Qual a motivação para pesquisadores localizados em países do "centro" fazerem colaborações com pesquisadores de países da "periferia", como o Brasil?

\section{Questões gerais}

a) Como você considera a inserção da pesquisa brasileira em genética humana e médica no cenário internacional? Que aportes o Brasil dá para esse estoque geral de conhecimentos? 
b) Você já sentiu dificuldades - para publicar um artigo ou participar de conferências internacionais - devido a sua nacionalidade?

c) Você considera que há diferenças regionais na forma de se fazer pesquisa em genética humana? Há especialização temática ou técnica?

d) A ida para os centros de pesquisa no exterior é importante para a formação de pesquisadores em sua área no Brasil?

e) Como sua pesquisa se insere no campo nacional e internacional da genética humana e médica? Que pergunta quer responder?

\section{Socioeconômico}

a) Profissão e nível educacional dos pais

b) Local e data de nascimento

c) Família 
Anexo 2 - Instituições de ensino e pesquisa e número de pesquisadores da amostra

\begin{tabular}{|c|c|c|c|}
\hline Instituição & Estado & Região & Pesquisadores \\
\hline USP & SP & Sudeste & 61 \\
\hline UFRGS & RS & Sul & 25 \\
\hline UFPA & PA & Norte & 20 \\
\hline UNICAMP & SP & Sudeste & 16 \\
\hline UFMG & MG & Sudeste & 16 \\
\hline UFPR & PR & Sul & 13 \\
\hline UNIFESP & SP & Sudeste & 12 \\
\hline UNESP & SP & Sudeste & 12 \\
\hline UFBA & BA & Nordeste & 11 \\
\hline UFPE & PE & Nordeste & 10 \\
\hline UFRJ & RJ & Sudeste & 9 \\
\hline UERJ & RJ & Sudeste & 9 \\
\hline UFCSPA & RS & Sul & 9 \\
\hline INCA & RJ & Sudeste & 8 \\
\hline Fiocruz RJ & RJ & Sudeste & 8 \\
\hline UNB & DF & Centro-Oeste & 8 \\
\hline UFAL & $A L$ & Nordeste & 7 \\
\hline UFSC & $\mathrm{SC}$ & Sul & 7 \\
\hline UFMT & MT & Centro-Oeste & 6 \\
\hline FAMERP & SP & Sudeste & 6 \\
\hline UFG & GO & Centro-Oeste & 5 \\
\hline UFU & MG & Sudeste & 5 \\
\hline UFPI & $\mathrm{PI}$ & Nordeste & 5 \\
\hline $\begin{array}{c}\text { Hospital } \\
\text { Sírio-Libanês }\end{array}$ & SP & Sudeste & 5 \\
\hline UESB & BA & Nordeste & 4 \\
\hline UNEB & BA & Nordeste & 3 \\
\hline UFC & CE & Nordeste & 3 \\
\hline UFMA & MA & Nordeste & 3 \\
\hline UFTM & MG & Sudeste & 3 \\
\hline UEL & PR & Sul & 3 \\
\hline UNIRIO & RJ & Sudeste & 3 \\
\hline UFF & RJ & Sudeste & 3 \\
\hline UNIR & $\mathrm{RO}$ & Norte & 3 \\
\hline HCPA & RS & Sul & 3 \\
\hline Hospital AC Camargo & SP & Sudeste & 3 \\
\hline $\begin{array}{l}\text { Instituto Israelita de } \\
\text { Ensino e Pesquisa } \\
\text { Albert Einstein }\end{array}$ & SP & Sudeste & 3 \\
\hline $\begin{array}{l}\text { Hemocentro de } \\
\text { Ribeirão Preto }\end{array}$ & SP & Sudeste & 3 \\
\hline
\end{tabular}




\begin{tabular}{|c|c|c|c|}
\hline UEA & AM & Norte & 2 \\
\hline Fiocruz Bahia & BA & Nordeste & 2 \\
\hline UNIFAL & MG & Sudeste & 2 \\
\hline UFPB & PB & Nordeste & 2 \\
\hline UFCG & PB & Nordeste & 2 \\
\hline UEM & PR & Sul & 2 \\
\hline UTFPR & PR & Sul & 2 \\
\hline UENF & RJ & Sudeste & 2 \\
\hline UFRN & RN & Nordeste & 2 \\
\hline UFPEL & RS & Sul & 2 \\
\hline UFSM & RS & Sul & 2 \\
\hline UFAC & $A C$ & Norte & 1 \\
\hline UFAM & AM & Norte & 1 \\
\hline UFRA & AM & Norte & 1 \\
\hline UNIFAP & $A P$ & Norte & 1 \\
\hline UEFS & BA & Nordeste & 1 \\
\hline UESC & BA & Nordeste & 1 \\
\hline UECE & CE & Nordeste & 1 \\
\hline UFRPE & PE & Nordeste & 1 \\
\hline UPE & PE & Nordeste & 1 \\
\hline UNIVASF & PE & Nordeste & 1 \\
\hline UEPB & PB & Nordeste & 1 \\
\hline UFS & SE & Nordeste & 1 \\
\hline UERN & RN & Nordeste & 1 \\
\hline UFMS & MS & Centro-Oeste & 1 \\
\hline \multicolumn{4}{|l|}{ Universidade } \\
\hline Católica de Brasília & DF & Centro-Oeste & 1 \\
\hline UFSCAR & SP & Sudeste & 1 \\
\hline FAMEMA & SP & Sudeste & 1 \\
\hline UFJF & MG & Sudeste & 1 \\
\hline UFSJ & MG & Sudeste & 1 \\
\hline UFES & ES & Sudeste & 1 \\
\hline \multicolumn{3}{|l|}{ Santa Casa de } & \\
\hline $\begin{array}{l}\text { Vitória } \\
\text { UNILA }\end{array}$ & $\begin{array}{l}\text { ES } \\
\text { PR }\end{array}$ & $\begin{array}{l}\text { Sudeste } \\
\text { Sul }\end{array}$ & $\begin{array}{l}1 \\
1\end{array}$ \\
\hline Unipampa & RS & Sul & 1 \\
\hline FURG & RS & Sul & 1 \\
\hline PUC RS & RS & Sul & 1 \\
\hline UFFS & SC & Sul & 1 \\
\hline Total & & & 381 \\
\hline
\end{tabular}


Anexo 3 - Quadro dos entrevistados

\begin{tabular}{|c|c|c|c|c|}
\hline & Sexo & Instituição & Formação & $\begin{array}{r}\text { Experiência } \\
\text { intemacional }\end{array}$ \\
\hline 1 & $\mathrm{~F}$ & UFPA & Biólogo & Não \\
\hline 2 & M & UFPA & Biólogo & Não \\
\hline 3 & $\mathrm{~F}$ & UFPA & Biólogo & Sim \\
\hline 4 & $\mathrm{~F}$ & UFPA & Biólogo & Não \\
\hline 5 & M & UFPA & Biólogo & Sim \\
\hline 6 & $\mathrm{~F}$ & UFPA & Médico & Não \\
\hline 7 & M & UFPA & Médico & Sim \\
\hline 8 & M & UFPA & Biólogo & Não \\
\hline 9 & M & UFPA & Biólogo & Sim \\
\hline 10 & $\mathrm{~F}$ & UFPA & Biólogo & Sim \\
\hline 11 & M & UFPA & Biólogo & Sim \\
\hline 12 & M & UFPA & Médico & Não \\
\hline 13 & M & UFPA & Biólogo & Não \\
\hline 14 & M & UFRGS & Médico & Sim \\
\hline 15 & $\mathrm{~F}$ & UFRGS & Biólogo & Não \\
\hline 16 & M & UFRGS & Biólogo & Sim \\
\hline 17 & M & UFRGS & Biólogo & Sim \\
\hline 18 & M & UFRGS & Biólogo & Sim \\
\hline 19 & $\mathrm{~F}$ & UFRGS & Biólogo & Sim \\
\hline 20 & $\mathrm{~F}$ & UFRGS & Médico & Não \\
\hline 21 & $\mathrm{~F}$ & UFRGS & Médico & Sim \\
\hline 21 & $\mathrm{~F}$ & UFRGS & Biólogo & Sim \\
\hline 23 & $\mathrm{~F}$ & UFRGS & Biólogo & Sim \\
\hline 24 & $\mathrm{~F}$ & UFRGS & Biólogo & Sim \\
\hline 25 & $\mathrm{M}$ & UFRGS & Biólogo & Sim \\
\hline 26 & M & UFRGS & Médico & Sim \\
\hline 27 & $\mathrm{~F}$ & UFRGS & Biólogo & Sim \\
\hline 28 & $\mathrm{~F}$ & Unicamp & Médico & Não \\
\hline 29 & $\mathrm{~F}$ & Unicamp & Biólogo & Não \\
\hline 30 & $\mathrm{~F}$ & Unicamp & Biólogo & Sim \\
\hline 31 & $\mathrm{~F}$ & Unicamp & Médico & Sim \\
\hline 32 & $\mathrm{~F}$ & Unicamp & Biólogo & Sim \\
\hline 33 & $\mathrm{~F}$ & Unicamp & Biólogo & Sim \\
\hline 34 & $\mathrm{~F}$ & Unicamp & Biólogo & Sim \\
\hline 35 & M & Unicamp & Biólogo & Não \\
\hline 36 & $\mathrm{~F}$ & Unicamp & Médico & Não \\
\hline 37 & M & USP/RP & Médico & Sim \\
\hline 38 & $\mathrm{~F}$ & USP/RP & Biólogo & Sim \\
\hline 39 & M & USP/RP & Biólogo & Não \\
\hline 40 & M & USP/RP & Médico & Sim \\
\hline 41 & M & USP/RP & Biólogo & Sim \\
\hline 42 & M & USP/RP & Médico & Sim \\
\hline 43 & $\mathrm{~F}$ & USP/RP & Biólogo & Sim \\
\hline 44 & $\mathrm{~F}$ & USP/RP & Biólogo & Sim \\
\hline 45 & M & USP/RP & Médico & Não \\
\hline 46 & $\mathrm{M}$ & USP/RP & Biólogo & Sim \\
\hline
\end{tabular}

